FOREST PRODUCTS INDUSTRY OF THE FUTURE PORTFOLIO STUDY AND EVALUATION

Prepared by Los Alamos Technical Associates, Inc.

Prepared for the Department of Energy Under Contract No. DE-AT07-01ID60457

May, 2002 


\section{FOREST PRODUCTS INDUSTRY OF THE FUTURE PORTFOLIO STUDY AND EVALUATION}

Table of Contents

Executive Summary

Section 1 Introduction

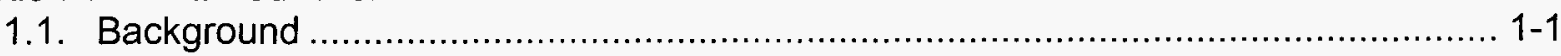

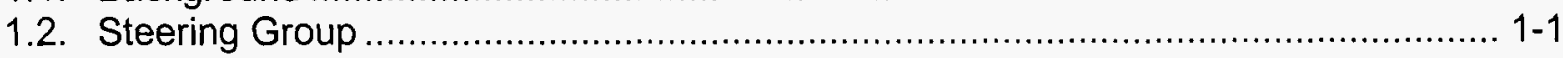

1.3. Additional Participants ....................................................................... $1-1$

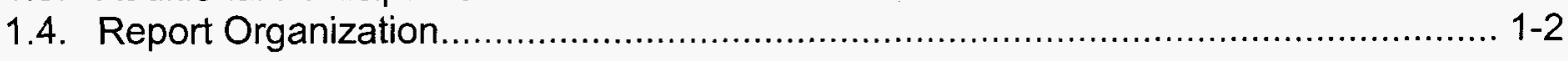

Section 2 Approach

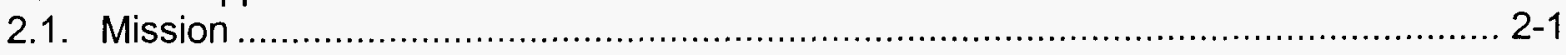

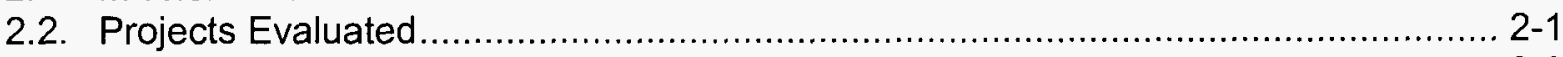

2.3. Designation of Projects for Evaluation .................................................... 2-2

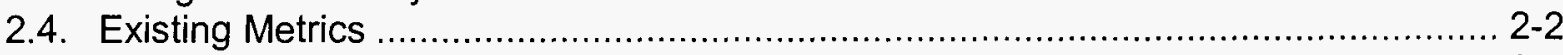

2.5. Development of the Project Evaluation System ........................................... 2-3

2.6. Project Evaluation Parameters ............................................................ 2-4

2.7. Validation of the Project Evaluation System ................................................. 2-8

2.8. Project Evaluation Process ....................................................................... 2-8

2.9. Stage of Development Approach to Portfolio Evaluation ..................................... 2-9

2.10. Development of Graphic Presentations of Data ........................................ 2-10

Section 3 Data and Observations

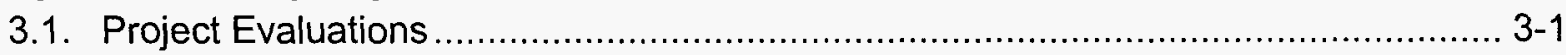

3.2. Stages of Development of Projects ........................................................ 3-7

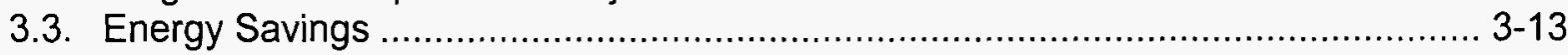

3.4. Value of the Agenda 2020 Program ........................................................ 3-17

3.5. Potential Economic Impacts of the Projects ............................................ 3-20

3.6. The R\&D Process ............................................................................ $3-20$

3.7. Agenda 2020 Implementation Plan and Portfolio ........................................ 3-21

3.8. Proposed New Technology Strategy............................................................ 3-23

3.9. Comparison of Agenda 2020 Implementation Plan to the
Proposed New Technology Strategy......................................................... $3-25$

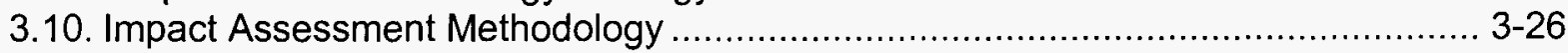

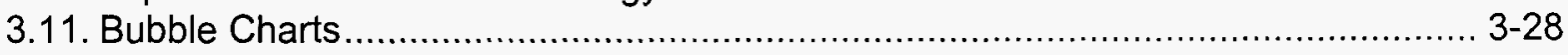

Section $4 \quad$ Conclusions and Recommendations

4.1. Conclusions ..................................................................................... 4-1

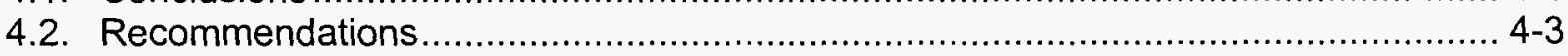

Acronyms and Abbreviations

References

Appendix A Index of Projects Selected for Study

Appendix B Instructions for Providing Technology Impact Projections

Appendix C Discussion Agenda

Appendix D Discussion of Abandoned Alternatives

Appendix E Individual Project Rating Sheets

Appendix F Agenda 2020 Implementation Plan R\&D Pathways

Appendix $G$ Proposed New Technology Strategy 
Table 2-1 — Project Evaluation System ............................................................ 2-4

Table 2-2 — Stages of Development.............................................................. 2-9

Table 3-1 — Weighted Ratings by Technology Groups ....................................... 3-1

Table 3-2 — Energy Performance Group Project Ratings ...................................... 3-2

Table 3-3 - Environmental Performance Group Project Ratings ............................... 3-3

Table 3-4 — Sustainable Forestry Group Project Ratings ......................................... 3-3

Table 3-5 — Improved Capital Effectiveness Group Project Ratings ........................... 3-4

Table 3-6 — Recycling Group Project Ratings ................................................ 3-5

Table 3-7 — Sensors and Controls Group Project Ratings ...................................... 3-6

Table 3-8 - Energy Performance Group Stages of Development.............................. 3-7

Table 3-9 - Environmental Performance Group Stages of Development ..................... 3-8

Table 3-10 — Sustainable Forestry Group Stages of Development............................. 3-8

Table 3-11 - Improved Capital Effectiveness Group Stages of Development ................ 3-9

Table 3-12 - Recycling Group Stages of Development....................................... 3-9

Table 3-13 - Sensors and Controls Group Stages of Development ........................ 3-10

Table 3-14 - Progression through Stages of Development by Project ...................... 3-12

Table 3-15 - Energy Performance Group Potential Energy Savings ........................... 3-13

Table 3-16 - Environmental Performance Group Potential Energy Savings................. 3-14

Table 3-17 - Sustainable Forestry Group Potential Energy Savings .......................... 3-15

Table 3-18 - Improved Capital Effectiveness Group Potential Energy Savings............. 3-15

Table 3-19 - Recycling Group Potential Energy Savings ....................................... 3-16

Table 3-20 - Sensors and Controls Group Potential Energy Savings ........................ 3-16 


\section{FOREST PRODUCTS INDUSTRY OF THE FUTURE}

PORTFOLIO STUDY AND EVALUATION

Figures

Figure 3-1 - Total Primary Energy Displaced vs. Time

Figure 3-2 - Total Annual Cost Savings vs. Time

Figure 3-3 - Agenda 2020 Implementation Plan vs. the Proposed New Technology Strategy

Bubble Charts showing Research Budget vs. Energy Savings vs. Weighted Rating

Figure 3-4 - All Projects 3-29

Figure 3-5 — Energy Performance Group Projects 3-30

Figure 3-6 - Environmental Performance Group Projects. 3-31

Figure 3-7 - Sustainable Forestry Group Projects 3-32

Figure 3-8 - Improved Capital Effectiveness Group Projects 3-33

Figure 3-9 - Recycling Group Projects 3-34

Figure 3-10 - Sensors and Controls Group Projects 3-35

Bubble Charts showing Research Budget vs. Weighted Rating vs. Development Stage

Figure 3-11 - All Projects 3-36

Figure 3-12 - Energy Performance Group Projects 3-37

Figure 3-13 - Environmental Performance Group Projects . 3-38

Figure 3-14 - Sustainable Forestry Group Projects 3-39

Figure 3-15 - Improved Capital Effectiveness Group Projects 3-40

Figure 3-16 - Recycling Group Projects 3-41

Figure 3-17 - Sensors and Controls Group Projects $3-42$ 


\title{
FOREST PRODUCTS INDUSTRY OF THE FUTURE
}

PORTFOLIO STUDY AND EVALUATION

\author{
Executive Summary
}

Los Alamos Technical Associates, Inc. (LATA) conducted an evaluation the potential impact and value of a portion of the current portfolio of R\&D projects supported by the Office of Industrial Technology and the Forest Products Industry of the Future

The mission of the evaluation was to:

a) Assess the potential impact of the projects to meet the critical goals of the industry as identified in the vision and roadmapping documents.

b) Evaluate the relationship between the current portfolio of projects and the Agenda 2020 Implementation Plan. In addition, evaluate the relationship between the portfolio and the newly revised draft technology strategy being created by the industry.

c) Identify areas where current efforts are making significant progress towards meeting industry goals and identify areas where additional work may be required to meet these goals. Identify how much of the potential energy benefits can be realized through the current portfolio of activities. Identify the economic impacts of this portfolio on the industry in years 2010 and 2020 , including reduced capital intensity, productivity improvements, reduced environmental costs, and safety improvements.

d) Make recommendations to the DOE and the Forest Products Industry on possible improvements in the portfolio and in the current methodology that DOE uses to assess potential impacts on its R\&D activities.

Projects were evaluated using existing DOE energy and environmental metrics. In addition, a Project Evaluation System was developed to address other measures of potential impact and to supplement the existing metrics. A scale to assess the stages of development appropriate to each of the projects was also developed to give visibility to the progress made in moving research projects along the path toward deployment. DOE and industry representatives collaborated with LATA in the development of these systems for evaluation.

Thirty-nine projects from the total portfolio of 105 projects were evaluated; they were distributed among the six areas of research. The Steering Group collaborated with the industry Chief Technical Officers (CTOs) to perform the down-selection on the basis of satisfying two criteria - those projects that were believed to have the greatest potential for impacting the industry's goals and those projects that allowed a test of the metrics. From an energy perspective, these thirty-nine projects accounted for almost all of the projected energy savings.

The Agenda 2020 program was found to be effective and well managed. The high degree of cooperation and collaboration existing between DOE and the forest products industry was unmistakable. A detailed discussion of each of the items in the mission of this evaluation can be found in the body of this report. Although it contains some critical findings and conclusions, the recommendations included herein should be considered in the context of making improvements to an already effective program. 


\section{FOREST PRODUCTS INDUSTRY OF THE FUTURE PORTFOLIO STUDY AND EVALUATION}

In general, the review of the portfolio demonstrated:

- The Agenda 2020 program shows noteworthy progress in tangible, quantifiable terms and has the potential to produce a substantial positive effect on energy and cost savings for the forest products industry and the nation as a whole.

- There are significant R\&D projects in the portfolio that were made possible by the shared risk aspects of the Agenda 2020 program-the Black Liquor Gasification Project is a good example.

- The Agenda 2020 program facilitates the industry's efforts to clarify needs, establish priorities, and focus the technology R\&D effort for the economic health of the industry and the nation.

- The forest products industry has taken the lead in redefining, reorganizing, and updating the original Agenda 2020 R\&D strategy.

- The Agenda 2020 program has stimulated the development of procedures to effectively evaluate the worth and diversity of R\&D projects necessary to maintain a robust program.

- The degree of collaboration that has developed between the industry, the government, and research organizations (including universities and national laboratories) fosters an environment with potential for more effective problem solving.

In conclusion, the Agenda 2020 program shows noteworthy progress in tangible, quantifiable terms and has the potential to produce a substantial positive effect on energy and cost savings for the forest products industry and the nation as a whole. The current portfolio represents a substantial level of real contribution across the full range of Agenda 2020 R\&D goals. The majority of projects evaluated in this study have the potential to produce a high impact. The progression toward commercial implementation shown by the projects evaluated in this study demonstrates that significant progress is being made toward the Agenda 2020 goals. Based on these conclusions, one of the primary recommendations in this report is to continue support for the Agenda 2020 program. 


\section{FOREST PRODUCTS INDUSTRY OF THE FUTURE}

PORTFOLIO STUDY AND EVALUATION

\section{Section 1}

Introduction

\subsection{Background}

"The Forest Products Industry was the first energy intensive industry to develop a technology vision and research agenda for the future. Published in November of 1994, Agenda $2020^{1}$ has become the basis for creating a path forward for the industry in pursuing common energy and environmental goals and to work with the U.S. Department of Energy (DOE) to create an effective industry research program". ${ }^{2}$ The purpose of this program is to evaluate opportunities of one of the largest energy users in the industrial sector to adopt more energy-efficient practices and technologies, thereby improving the efficiency of and reducing the Nation's future utilization of fossil energy and its emissions of greenhouse gases. A cooperative effort between the DOE's Office of Industrial Technology (OIT) and the Forest Products Industry provides the support necessary to enable this program. This support is channeled through a number of research and development projects that constitute the "R\&D Portfolio." In February 2001, DOE commissioned a study to evaluate the potential impact and value of selected projects within the R\&D portfolio. Los Alamos Technical Associates, Inc. (LATA) and their subcontractor, Mid-South Engineering Company (MSECO), were awarded the contract to perform this study. This report presents the results of that study.

\subsection{Steering Group}

The study process was carried out in close collaboration with DOE and forest product industry officials. A Steering Group was convened to provide direction and guidance for the study through a series of regularly scheduled conference calls. The Steering Group consisted of the following members:

Ben Thorp - Director of Pulp and Paper Engineering, Georgia Pacific Corporation John Glomb - Vice President, Corporate Research, Westvaco (Retired) Valri Robinson - Forest Products Team Leader, Department of Energy David W. Robertson - Project Manager, Department of Energy

\subsection{Additional Participants}

The Principal Investigators (PI) and/or field project managers for each of the projects studied provided a first-hand perspective and specific information regarding their projects through a series of discussions. The Agenda 2020 Task Group Co-Chairs provided an overview and a broader perspective on the projects within the groups under their cognizance.

\footnotetext{
'Agenda 2020: A Technology Vision

2 Statement of Work
} 


\section{FOREST PRODUCTS INDUSTRY OF THE FUTURE \\ PORTFOLIO STUDY AND EVALUATION}

\subsection{Report Organization}

This report is organized and presented in four main sections. Section 1 is a brief introduction to the report. Section 2 describes the evolution of the approach used to perform this study. Section 3 presents the highlights of the data collected and/or generated during the study and pertinent observations in that regard. Section 4 presents conclusions reached and recommendations for the future based on the study work that was performed. Specific portions were included to group all of the acronyms and abbreviations that were used in the report and to list references that were cited in the report. Appendices to the report collect study details such as data sets, project rating sheets, discussion notes, etc. 
Section 2

Approach

\subsection{Mission}

The Request for Proposals (RFP) for this study listed several objectives in its Statement of Work (SOW). These were as follows:

- Assess the potential impact of the portfolio of projects selected for this study to meet industry goals.

- Evaluate the relationship of these projects to the Agenda 2020 Implementation Plan. ${ }^{3}$

- Evaluate the relationship of these projects to the newly revised draft technology strategy. ${ }^{4}$

- Identify areas of significant progress and areas where additional work may be required.

- Assess the validity of energy and environmental metrics for each selected project and, if appropriate, discuss reasonable adjustments to the estimates of potential impacts.

- Identify the potential energy benefits of the portfolio of projects selected for this study.

- Identify the potential economic impacts—reduced capital intensity, productivity improvements, reduced environmental costs, and safety improvements-to the forest products industry in 2010 and 2020.

- Recommend improvements to the portfolio.

- Recommend improvements to the methodology used to assess potential impacts.

\subsection{Projects Evaluated}

At the time of commencement of the study, the DOE/Industry portfolio of projects to support the Agenda 2020 Implementation Plan included one hundred and five projects with additional projects under negotiation. In addition, there were nine projects funded by the U.S. Department of Agriculture. At the outset, it became apparent that the resources necessary to evaluate all of the projects in the portfolio in the depth required to develop useful conclusions and recommendations for the Agenda 2020 program were not available. Accordingly, the Steering Group took the initiative to reduce the scope for the study to fit within the funding limitations for this work. The number of projects to be evaluated was reduced to a total of thirty-nine projects distributed among the six areas of research. The Steering Group collaborated with the industry Chief Technical Officers (CTOs) to perform the down-selection on the basis of satisfying two criteria - those projects that were believed to have the greatest potential for impacting the industry's goals and those projects that allowed a test of the metrics. From an energy perspective, these thirty-nine projects accounted for almost all of the projected energy savings.

Appendix $A$ is an index of the thirty-nine projects that were selected for this study. The projects are organized into the areas of research and task groups under which they are being performed. An item number and short project description identifies each project. The item numbers were assigned sequentially and are of reference value only for purposes of this study. Additional information listed in Appendix A for each project includes the recipient of the contract, contact information, Office of Industrial Technologies Information System (OITIS) number, contract agreement number, a checklist of project information available for

\footnotetext{
${ }^{3}$ Agenda 2020: The Path Forward

${ }^{4}$ Technology Summit
} 


\section{FOREST PRODUCTS INDUSTRY OF THE FUTURE PORTFOLIO STUDY AND EVALUATION}

the study (data sheets, quarterly and/or final reports, and proposal), and the filename for the metrics data sheet.

\subsection{Designation of Projects for Evaluation}

During the course of evaluating the projects, it was noted that certain projects were so closely related to each other that considering them independently led to a high level of redundancy in reporting of results. Consequently, Project \#0a (Biomass Gasification Combined Cycle), Project \#0b (Demonstration of Black Liquor Gasification at Big Island), and Project \#3 (Black Liquor Gasification Demonstration) were combined for study purposes into a single group identified as Project \#3 (Gasification Group of Projects). It should be noted that the R\&D costs and the benefits associated with the Gasification Group of Projects represent additional projects as well. Project \#32 actually consisted of two projectsFeedstock-to-Product Characterization Tools for the Wood and Pulp Industry AND/OR Development of a Field-Mobile NIR for Measurement of Standing Wood Properties-with individual proposals and metrics data sheets. These two projects were combined into a single project identified as Project \#32 (Development of a Field-Mobile NIR for Measurement of Standing Wood Properties) and only its data sheet was used to avoid double-counting of the benefits attributed to these closely related projects. The net result of combining these projects resulted in the designation of thirty-seven projects numbered 1 through 37 for purposes of this report.

\subsection{Existing Metrics}

The Government Performance and Results Act of 1993 (GPRA) was enacted to create and institutionalize processes within all federal agencies that would enhance performance and management for results. Inherent in these processes was the need to establish appropriate performance measures. In order to implement the GPRA requirements with regard to R\&D and demonstration projects receiving assistance from the OIT, a method of obtaining and quantifying technology impacts for R\&D projects was devised. This method employs Technology Impact Projections spreadsheets, referred to hereinafter as GPRA spreadsheets, that are intended to address a wide range of industries including the forest products industry. The information contained in these spreadsheets was generated in accordance with a set of instructions that are included as Appendix B to this report.

The metrics data sheets provided for this study consisted of a set of energy, environmental, and cost metrics that had been developed previously, in the form of GPRA spreadsheets for most of the projects to be evaluated under this study. The GPRA spreadsheet model contains a data table with factors such as combustion emission rates for various fuels, industrial energy prices, energy content of fuels, and projected fossil fuel generation mixes. The assumptions used in this table and the results are updated annually. The GPRA spreadsheets for the projects reviewed contained projections based on calculations made using the data tables from the various years in which these projects started. For purposes of this study, the data tables in all of these GPRA spreadsheets were updated to reflect the most current data thereby normalizing the projected impacts for the evaluations made herein.

Projected energy savings benefits for the selected Forest Products project portfolio were based on OIT's analyses of 36 individual projects and the Biomass and Black Liquor Gasification Demonstration Initiative. One older project never had a GPRA spreadsheet completed; therefore no energy savings were contributed to it. 
The Principal Investigators (PIs) filled out data collection sheets that provided the inputs used to by OIT to model the impacts shown on the GPRA spreadsheets for their respective projects. The Pl's were provided data regarding forest products to assist them in developing their assumptions. Each Pl's submission was reviewed by OIT to ensure that the assumptions were reasonable and realistic. In some cases, when OIT transcribed data from the data collection sheets into the GPRA spreadsheets the narrative assumptions were omitted. In a few cases adjustments were made to PI assumptions and calculations.

The benefits for the Forest Products Industry include the projected impacts of the Biomass and Black Liquor Gasification Demonstration Initiative, even though this project is carried in the OIT Combustion Program. The analysis of the Initiative was based on industry assessments of the power generation potential of black liquor and biomass gasification systems prepared by Larson et al..$^{5}$ It is the data for the initiative as a whole that is included in the Forest Products GPRA spreadsheet, rather than the benefits estimated for the individual, enabling research projects being funded by the Forest Products program.

The benefits for the projects in the current study include some overlap and the assumption of one hundred percent technical success; therefore, the implied overall impact for these projects is a considerable overstatement of the true potential. It is not practical to remove the redundancy or to develop more accurate estimates for probabilities of technical and commercial success at this time; however, a substantial level of real contribution is implied for the current portfolio.

\subsection{Development of the Project Evaluation System}

The existing metrics were recognized as important but insufficient to provide all of the data necessary to meet the objectives of this study. As a result, a Project Evaluation System was developed through a collaborative effort. The expectations of the Agenda 2020 program were used to establish some basic measures for evaluating the significance of the contributions made by individual projects. A scheme was devised to subjectively evaluate these projects as to their significance towards achieving these expectations and accelerating the demonstration, evaluation and implementation of the technologies and new scientific knowledge. Because these expectations were broad in nature and sometimes embodied multiple considerations, they were broken down into a set of goals to provide a clearer focus for the evaluation process. An initial set of fourteen parameters was proposed for the evaluation of each project against these goals. The Steering Group reviewed these parameters with the CTOs and these parameters were reduced to a set of eleven that further refined the focus and eliminated duplication and overlap. A compact numerical scale was devised with the bottom of the scale receiving a " 0 " for those parameters for which a project's contributions have "no significance or applicability" and the top of the scale receiving a " 5 " for "highly significant" contributions. The sum of the values assessed for these parameters for each project produced a "Raw" rating. The relative importance of each of the eleven parameters was established by assigning a numerical "weighting value" to each on a scale between 1 and 10 with 10 being given to the most important parameter and proportionally lower numbers to parameters of lesser importance. The Steering Group

\footnotetext{
${ }^{5}$ E.D. Larson, T.G. Kreutz, S. Consonni, Combined Biomass and Black Liquor Gasifier/Gas Turbine Cogeneration at Pulp and Paper Mills; E.D. Larson, T.G. Kreutz, S. Consonni, Preliminary Economics of Black Liquor Gasifier/Gas Turbine Cogeneration at Pulp and Paper Mills; E.D. Larson et al., A costbenefit assessment of BLGCC technology.
} 


\section{FOREST PRODUCTS INDUSTRY OF THE FUTURE PORTFOLIO STUDY AND EVALUATION}

collaborated with the CTOs to establish a consensus for these weighting values. The raw numbers for each parameter were multiplied by its weighting factor and the sum of these products produced a "Weighted" rating for each project.

The eleven parameters for evaluation, the " 0 to 5 " rating scale, and the weighting factors that constitute the Project Evaluation System for this study are presented in the Table 2-1 below.

\begin{tabular}{|c|c|c|c|c|c|c|c|c|}
\hline \multirow[b]{2}{*}{ \# } & \multirow[b]{2}{*}{ Parameter } & \multicolumn{6}{|c|}{ Rating Scale (Significance) } & \multirow[b]{2}{*}{$\begin{array}{c}\text { CTO } \\
\text { Weighting }\end{array}$} \\
\hline & & $\begin{array}{c}\text { N/A } \\
0\end{array}$ & $\begin{array}{c}\text { Some } \\
1\end{array}$ & 2 & $\begin{array}{c}\text { Moderate } \\
3\end{array}$ & 4 & $\begin{array}{c}\text { High } \\
5\end{array}$ & \\
\hline 1 & $\begin{array}{l}\text { Sustained forest resource } \\
\text { management }\end{array}$ & & & & & & & 10 \\
\hline 2 & $\begin{array}{l}\text { Size and extent of market for the new } \\
\text { technology }\end{array}$ & & & & & & & 9 \\
\hline 3 & Energy performance & & & & & & & 8 \\
\hline 4 & Economic attractiveness & & & & & & & 8 \\
\hline 5 & Technology champion & & & & & & & 7 \\
\hline 6 & $\begin{array}{l}\text { Scientific insights derived from } \\
\text { project }\end{array}$ & & & & & & & 7 \\
\hline 7 & Improved environmental performance & & & & & & & 7 \\
\hline 8 & Technological leadership & & & & & & & 7 \\
\hline 9 & Recycled wood and paper materials & & & & & & & 6 \\
\hline 10 & Risk & & & & & & & 6 \\
\hline 11 & Alternate uses for biomass & & & & & & & 5 \\
\hline
\end{tabular}

Table 2-1

Project Evaluation System

\subsection{Project Evaluation Parameters}

During the course of evaluating projects, it was noted that the eleven parameters selected for evaluation are subject to varied interpretations and results. Generally these parameters were found to be influenced by a number of factors. In order to take these factors into account and make the evaluation process as consistent as reasonably possible, guidelines were developed for assigning values to each parameter. Intermediate numbers were interpolated as appropriate to the project being evaluated. The windowpane diagrams presented below depict the guidelines that evolved and were used for this study. 


\section{FOREST PRODUCTS INDUSTRY OF THE FUTURE PORTFOLIO STUDY AND EVALUATION}

The Sustained Forest Resource Management parameter was considered to be most heavily influenced by tree growth rate and the degree of utilization of forest resources (recycling, use of waste materials, etc.) that would reduce the demand for trees. The diagram below indicates the guidelines for assigning raw rating numbers for this parameter.

\begin{tabular}{|c|c|c|}
\hline $\begin{array}{c}\text { Sustained Forest Resource } \\
\text { Management }\end{array}$ & Low Tree Growth Rate & High Tree Growth Rate \\
\hline $\begin{array}{c}\text { High Utilization of Forest } \\
\text { Resources }\end{array}$ & 3 & 5 \\
\hline $\begin{array}{c}\text { Low Utilization of Forest } \\
\text { Resources }\end{array}$ & 1 & 3 \\
\hline
\end{tabular}

The Size and Extent of the Market for the New Technology was considered to be most heavily influenced by the potential number of mills, units, plants, sites, etc. where the new technology could be implemented, and the existence of drivers (economic, regulatory, political, business growth, etc.) that would encourage the implementation of the technology. The diagram below indicates the guidelines for assigning raw rating numbers for this parameter.

\begin{tabular}{|c|c|c|}
\hline $\begin{array}{c}\text { Size and Extent of Market for the } \\
\text { New Technology }\end{array}$ & $\begin{array}{c}\text { Small Potential Market } \\
\text { (Few Amenable Units) }\end{array}$ & $\begin{array}{c}\text { Large Potential Market } \\
\text { (Many Amenable Units) }\end{array}$ \\
\hline $\begin{array}{c}\text { Multiple Drivers (Economic, } \\
\text { Regulatory, Political, Growth) }\end{array}$ & 3 & 5 \\
\hline No Apparent Drivers & 1 & 3 \\
\hline
\end{tabular}

Energy Performance was considered to be most heavily influenced by the improvement in energy performance on a per unit basis and the potential number of units (mills, plants, sites, etc.) that were amenable to the new technology. The diagram below indicates the guidelines for assigning raw rating numbers for this parameter.

\begin{tabular}{|c|c|c|}
\hline Energy Performance & $\begin{array}{c}\text { Small Improvement in Energy } \\
\text { Performance per Unit }\end{array}$ & $\begin{array}{c}\text { Large Improvement in Energy } \\
\text { Performance per Unit }\end{array}$ \\
\hline $\begin{array}{c}\text { Broad Range of Application } \\
\text { (Many Amenable Units) }\end{array}$ & 3 & 5 \\
\hline $\begin{array}{c}\text { Narrow Range of Application } \\
\text { (Few Amenable Units) }\end{array}$ & 1 & 3 \\
\hline
\end{tabular}




\section{FOREST PRODUCTS INDUSTRY OF THE FUTURE \\ PORTFOLIO STUDY AND EVALUATION}

Economic Attractiveness was considered to be most heavily influenced by the anticipated value of the benefit and implementation cost for the technology. The diagram below indicates the guidelines for assigning raw rating numbers for this parameter.

\begin{tabular}{|c|c|c|}
\hline Economic Attractiveness & Low Benefit Value & High Benefit Value \\
\hline Low Implementation Cost & 3 & 5 \\
\hline High Implementation Cost & 1 & 3 \\
\hline
\end{tabular}

The Technology Champion parameter was considered to be most heavily influenced by the degree of industry support and the enthusiasm expressed by the technologists. The diagram below indicates the guidelines for assigning raw rating numbers for this parameter.

\begin{tabular}{|c|c|c|}
\hline Economic Attractiveness & Low Industry Support & High Industry Support \\
\hline High Technologist Enthusiasm & 3 & 5 \\
\hline Low Technologist Enthusiasm & 1 & 3 \\
\hline
\end{tabular}

The Scientific Insights Derived from Project parameter was considered to be most heavily influenced by the envisioning of new applications or significant improvements to current applications and the degree of knowledge gained from the project. The diagram below indicates the guidelines for assigning raw rating numbers for this parameter.

\begin{tabular}{|c|c|c|}
\hline $\begin{array}{c}\text { Scientific Insights Derived from } \\
\text { Project }\end{array}$ & $\begin{array}{c}\text { No New Applications or } \\
\text { Improvements Envisioned }\end{array}$ & $\begin{array}{c}\text { Significant New Applications or } \\
\text { Improvements Envisioned }\end{array}$ \\
\hline $\begin{array}{c}\text { New or Deeper Knowledge } \\
\text { Gained }\end{array}$ & 3 & 5 \\
\hline Little Knowledge Gained & 1 & 3 \\
\hline
\end{tabular}

Improved Environmental Performance was considered to be most heavily influenced by the improvement in environmental performance on a per unit basis and the potential number of units (mills, plants, sites, etc.) that were amenable to the new technology. The diagram below indicates the guidelines for assigning raw rating numbers for this parameter.

\begin{tabular}{|c|c|c|}
\hline Environmental Performance & $\begin{array}{c}\text { Small Improvement in } \\
\text { Environmental Performance per } \\
\text { Unit }\end{array}$ & $\begin{array}{c}\text { Large Improvement in } \\
\text { Environmental Performance per } \\
\text { Unit }\end{array}$ \\
\hline $\begin{array}{c}\text { Broad Range of Application } \\
\text { (Many Amenable Units) }\end{array}$ & 3 & 5 \\
\hline $\begin{array}{c}\text { Narrow Range of Application } \\
\text { (Few Amenable Units) }\end{array}$ & 1 & 3 \\
\hline
\end{tabular}




\section{FOREST PRODUCTS INDUSTRY OF THE FUTURE \\ PORTFOLIO STUDY AND EVALUATION}

Technological Leadership was considered to be most heavily influenced by the expected range of issues or products affected by the project and the size of the impact sought by the project. The diagram below indicates the guidelines for assigning raw rating numbers for this parameter.

\begin{tabular}{|c|c|c|}
\hline Technological Leadership & $\begin{array}{c}\text { Narrow Industry Focus } \\
\text { (Single Issue/Single Product) }\end{array}$ & $\begin{array}{c}\text { Broad Industry Focus } \\
\text { (Cross-cutting Issues/Products) }\end{array}$ \\
\hline $\begin{array}{c}\text { Seeks Revolutionary or } \\
\text { Breakthrough Technology }\end{array}$ & 3 & 5 \\
\hline $\begin{array}{c}\text { Seeks Incremental Changes or } \\
\text { Improvements }\end{array}$ & 1 & 3 \\
\hline
\end{tabular}

The Recycled Wood and Paper Materials parameter was considered to be most heavily influenced by the degree of beneficial utilization of waste materials and the degree of avoidance of waste treatment and disposal processes anticipated from the project. The diagram below indicates the guidelines for assigning raw rating numbers for this parameter.

\begin{tabular}{|c|c|c|}
\hline $\begin{array}{c}\text { Recycled Wood and Paper } \\
\text { Materials }\end{array}$ & $\begin{array}{c}\text { Low Utilization of Waste } \\
\text { Materials }\end{array}$ & $\begin{array}{c}\text { High Utilization of Waste } \\
\text { Materials }\end{array}$ \\
\hline $\begin{array}{c}\text { High Avoidance of Waste } \\
\text { Treatment/Disposal }\end{array}$ & 3 & 5 \\
\hline $\begin{array}{c}\text { Low Avoidance of Waste } \\
\text { Treatment/Disposal }\end{array}$ & 1 & 3 \\
\hline
\end{tabular}

Risk was considered to be most heavily influenced by the probability of project success and the probability of success at the next stage of development for the technology. In this case, high-risk prospects were given a rating of 0 . The diagram below indicates the guidelines for assigning raw rating numbers for this parameter.

\begin{tabular}{|c|c|c|}
\hline Risk & $\begin{array}{c}\text { Moderate Probability of Project } \\
\text { Success }\end{array}$ & $\begin{array}{c}\text { High Probability of Project } \\
\text { Success }\end{array}$ \\
\hline $\begin{array}{c}\text { High Probability of Success } \\
\text { at Next Stage of Development }\end{array}$ & 3 & 5 \\
\hline $\begin{array}{c}\text { Moderate Probability of Success } \\
\text { at Next Stage of Development }\end{array}$ & 1 & 3 \\
\hline
\end{tabular}

The Alternate Uses of Biomass parameter was considered to be most heavily influenced by the degree of innovation for biomass utilization and the anticipated volume of biomass to be used. The diagram below indicates the guidelines for assigning raw rating numbers for this parameter.

\begin{tabular}{|c|c|c|}
\hline Alternate Uses of Biomass & $\begin{array}{c}\text { Existing Application for Biomass } \\
\text { Utilization }\end{array}$ & $\begin{array}{c}\text { New Application for Biomass } \\
\text { Utilization }\end{array}$ \\
\hline High Volume of Biomass Use & 3 & 5 \\
\hline Low Volume of Biomass Use & 1 & 3 \\
\hline
\end{tabular}

May, 2002 


\subsection{Validation of the Project Evaluation System}

An initial group of six projects, one from each of the six technology groups, was evaluated using the Project Evaluation System. The results of these were reviewed with the Steering Group to see if the system produced reasonable results. Although not all of the results corresponded with intuitive expectations, discussions about the ratings of these projects in each of the parameters required by the system provided a more comprehensive view of these projects and resulted in the decision to proceed systematically with further evaluations. The next evaluations considered the technology groups in which the highest and lowest project ratings were initially produced. In the group with the highest rating, the project that was intuitively expected to produce the lowest rating was selected for evaluation. Similarly, in the group with the lowest rating, the project that was expected to produce the highest rating was also selected. The results of these evaluations were subsequently reviewed with the Steering Group and a consensus emerged that the Project Evaluation System provided a new perspective regarding the potential impacts of the projects that could be useful. Based on that consensus, the decision was made to proceed with the evaluation of a complete group of projects and consult with the Co-Chair for that group to bring in an additional perspective that might temper the evaluations. The ratings of projects in this first complete group were reviewed with the Steering Group with the resultant decision that this system should be used to evaluate the remainder of the projects selected for this study.

\subsection{Project Evaluation Process}

The process for evaluating each project began with an internal review of the data provided for the study (project proposals, project data sheets, quarterly and final reports, and GPRA spreadsheets). These reviews were followed by a discussion with the Principal Investigator (PI) for the project. The discussion was structured around an agenda that was developed for this study to provide consistency in the process. Prior to the discussions, this agenda was reviewed by the Steering Group and adjusted to address potential concerns. Appendix $\mathrm{C}$ contains the initial discussion agenda that was developed for this process. This agenda was used during the first round of discussions to solicit the information for the initial project evaluations. Following validation of the Project Evaluation System, the discussion agenda was reorganized to focus specifically on the evaluation parameters used for this study. The revised discussion agenda is also presented in Appendix C.

Following the discussion with the $\mathrm{Pl}$, a raw rating for each project was developed. After raw ratings of all of the projects in a Task Group were developed, a second discussion was held with the Co-chair(s) for that Task Group. ${ }^{6}$ The preliminary results of the evaluations (raw ratings) were discussed with the Co-chairs to gather additional input from a different perspective. Adjustments were made to the raw ratings to address disparities in views as

\footnotetext{
${ }^{6}$ The Task Group Co-Chairs consulted with were as follows: Energy Performance Group: Paul Tucker, International Paper Environmental Performance Group: Dan Sjolseth, Weyerhaeuser Sustainable Forestry Group: John Pait, The Timber Co.; and Marshall Jacobson, The Timber Co. Improved Capital Effectiveness Group: John Huyck, Mead; and Ben Thorp, Georgia Pacific Recycling Group: Tom Friberg, Weyerhaeuser Sensors and Controls Group: G. Ron Brown, Westvaco
} 


\section{FOREST PRODUCTS INDUSTRY OF THE FUTURE PORTFOLIO STUDY AND EVALUATION}

appropriate. Once the final raw ratings were established, weighted ratings were generated and graphed and these were then reviewed in conference with the Steering Group.

Other approaches to the project evaluation process were considered and abandoned. A discussion of these may be found in Appendix D.

\subsection{Stage of Development Approach to Portfolio Evaluation}

The difficulties encountered in attempting to relate individual projects to a schedule-based measure of progress along the Agenda 2020 R\&D pathways highlighted the need for an approach that focused on the R\&D process itself. There were several instances of projects with high evaluation ratings that, in and of themselves, showed little or no energy savings, environmental performance improvements, or economic advantages. These projects were variously recognized as "enabling" or "gateway" projects meaning that they were precursors to follow-on projects that might possibly demonstrate and quantify these benefits. There were also some basic research projects, such as gene mapping that were designed to obtain fundamental knowledge which might lead to any number of unforeseeable future projects. Although these individual projects often lacked a clear logical relationship to other projects, the R\&D process in general consisted of a number of stages that followed a logical progression.

As a result, six stages of development were identified, defined, and associated with a numerical scale that represented the progression of these stages. Table 2-2 presents these stages and their definitions.

\begin{tabular}{|c|l|l|}
\hline Scale & Stage Description & Definitions \\
\hline 1 & Basic/Fundamental Research & $\begin{array}{l}\text { Fundamental, theoretical or experimental investigation } \\
\text { to advance scientific knowledge, the immediate practical } \\
\text { application of which is not a direct objective. }\end{array}$ \\
\hline 2 & Applied Research & $\begin{array}{l}\text { Research directed toward using knowledge gained by } \\
\text { basic research to make things or to create situations } \\
\text { that will serve a practical or utilitarian purpose. }\end{array}$ \\
\hline 3 & $\begin{array}{l}\text { Process or Equipment } \\
\text { Development/lmprovement } \\
\text { and/or equipment required to bring a new process to the } \\
\text { production stage, generally includes lab/pilot scale work. }\end{array}$ \\
\hline 5 & $\begin{array}{l}\text { Technology Scale-up; } \\
\text { Equipment Improvement } \\
\text { Dechnology/Equipment }\end{array}$ & $\begin{array}{l}\text { Design of a production unit based on lab/pilot scale } \\
\text { work. } \\
\text { Demonstration in a production environment. }\end{array}$ \\
\hline 6 & Commercial Deployment & $\begin{array}{l}\text { Equipment available, sold, installed, and in use in one or } \\
\text { more additional production facilities. }\end{array}$ \\
\hline
\end{tabular}

Table 2-2

Stages of Development

As with the Project Evaluation System, the Stages of Development scale was reviewed by the Steering Group through a series of conference calls. The projects evaluated to date were categorized using this scale and a consensus was reached that this approach was viable and could provide useful data. During these reviews it was noted that these Stages of Development provided a simple mechanism for relating the projects being evaluated to the general progression of the Agenda 2020 R\&D effort. This approach thus provided a tool to view the balance between projects of various types within the portfolio. Whereas 


\section{FOREST PRODUCTS INDUSTRY OF THE FUTURE PORTFOLIO STUDY AND EVALUATION}

consideration of basic research and enabling/gateway projects previously was given on an ad hoc basis, these types of projects now could be viewed systematically using this tool. Such a practice could provide the benefit of greater assurance that each task group had projects that spanned the range of stages of development and kept their R\&D pipelines filled. This benefit took on additional significance when viewed as a management tool to move R\&D efforts through the pipelines with a focus on advancing knowledge through the system thus facilitating the development of more comprehensive large-scale demonstration projects.

\subsection{Development of Graphic Presentations of Data}

Several formats were proposed for the presentation of data collected and generated during the course of the study. These included various forms of bubble charts and barcharts showing data from the GPRA spreadsheets, Project Evaluation System, and Stage of Development determinations. Through a process of systematic reviews with the Steering Committee, it was decided to use seven sets of two bubble charts and two stacked barcharts to graphically present the results of this study. The two bubble charts depicted energy savings from the GPRA spreadsheets vs. weighted ratings from the project evaluations and Stages of Development vs. weighted ratings from the project evaluations. On both bubble charts the size of the bubble was proportional to the R\&D funds committed to the project. One set of charts was prepared for each of the six task groups and one set was prepared to summarize the results for all of the projects that were evaluated. The two stacked barcharts depicted total energy displaced vs. time and total annual cost savings vs. time. 


\section{FOREST PRODUCTS INDUSTRY OF THE FUTURE}

PORTFOLIO STUDY AND EVALUATION

\section{Section 3}

\section{Data and Observations}

\subsection{Project Evaluations}

Each of the thirty-seven projects considered in this study were evaluated using the Project Evaluation System described in Section 2 of this report. A full set of Rating Sheets showing the details of each project's ratings by specific evaluation parameters with the evaluator's comments are presented in Appendix $\mathrm{E}$. It should be noted that these evaluations were based on a "snap shot" of the projects at the time of evaluation and would be subject to change according to additional information obtained from the ongoing R\&D program or external sources in the future. Under the Project Evaluation System, the theoretical maximum weighted rating possible is 400 . From a practical perspective, the diversity of factors considered in the evaluations effectively precludes any project from achieving such a high rating and ratings in the proximity of 300 should be considered exceptionally high and those in the range of 150 to 250 should be considered highly rated. Those projects receiving ratings below 150 were perceived to be technically well conceived but lower rated on the basis of the evaluation parameters that were determined for this study. A summary of the low, high, and average weighted ratings arranged by technology group is presented in Table 3-1.

\begin{tabular}{|l|c|c|c|}
\hline Technology Group & $\begin{array}{c}\text { Group } \\
\text { Low }\end{array}$ & $\begin{array}{c}\text { Group } \\
\text { High }\end{array}$ & $\begin{array}{c}\text { Group } \\
\text { Average }\end{array}$ \\
\hline Energy Performance & 194 & 307 & 229 \\
\hline Environmental Performance & 144 & 277 & 196 \\
\hline Sustainable Forestry & 224 & 303 & 282 \\
\hline Improved Capital Effectiveness & 85 & 246 & 204 \\
\hline Recycling & 175 & 265 & 229 \\
\hline Sensors and Controls & 44 & 293 & 198 \\
\hline
\end{tabular}

Table 3-1

Weighted Ratings by Technology Groups

The overall average of the weighted ratings for all thirty-seven projects is 219 . Each of the technology groups has average ratings of this general magnitude with individual projects having ratings above this overall average. One group, Sustainable Forestry, stands out in this comparison because of its notably high group average and the fact that all of the projects in this group are above the overall average. Two of the groups, Improved Capital Effectiveness and Sensors and Controls show at least one project with a rating below 100. A summary of the project evaluation ratings and observation highlights organized by technology group is presented in the following paragraphs. 


\section{FOREST PRODUCTS INDUSTRY OF THE FUTURE PORTFOLIO STUDY AND EVALUATION}

\section{Energy Performance Group Project Evaluations}

The raw and weighted ratings for the projects in the Energy Performance group are shown in Table 3-2.

\begin{tabular}{|c|l|c|c|}
\hline Project \# & Project Name & $\begin{array}{c}\text { Raw } \\
\text { Rating }\end{array}$ & $\begin{array}{c}\text { Weighted } \\
\text { Rating }\end{array}$ \\
\hline $01-785$ & Multiport Cylinder Dryer & 27 & 201 \\
\hline $02-933$ & Methane DeNO & 31 & 216 \\
\hline $03-993$ & Gasification Group of Projects & 42 & 307 \\
\hline $04-1110$ & Intermediate Sized Entrained Particles & 26 & 194 \\
\hline $05-1166$ & 3-D Characterization of Structure & 31 & 229 \\
\hline
\end{tabular}

Table 3-2

Energy Performance Group Project Ratings

The weighted ratings of the projects in the Energy Performance group ranged from a low of 194 to a high of 307 with a group average of 229 for the five projects that were evaluated. The Energy Performance group of projects demonstrated a high degree of consistency in the weighted ratings with four of the five projects in this group showing ratings between 194 and 229. Within this group, the evaluation parameters "Size and Extent of Market for the Technology" and "Scientific Insights Derived from the Project" showed the highest raw rating averages ( $>4.0$ on a scale of 0.0 to 5.0 ). The "Sustained Forest Resource Management", "Recycled Wood and Paper Materials" evaluation parameters showed the lowest raw rating averages ( $<1.0$ on a scale of 0.0 to 5.0$)$.

The one "outlier" in this group, the Gasification Group of Projects rated well above the group average with a weighted rating of 307 , the highest rating among the thirty-seven projects that were evaluated. The Gasification Group of Projects consists of three projects including the largest single project funded under the Agenda 2020 program, the Big Island Black Liquor Gasification Demonstration project. Associated with this project is the Engineering Study project, which had its own separate project number and was preliminary to the demonstration project. The GPRA spreadsheet energy data available for these projects dealt with the whole gasification scenario including not only black liquor gasification at kraft mills (Big Island is a soda mill), but also the energy that could ultimately be generated from the gasification, on a large scale, of forest biomass materials. As a consequence, the three gasification projects, Big Island Black Liquor engineering study and demonstration projects and the New Bern Biomass Gasification project were grouped and treated as a single gasification effort for this study. In addition to showing the highest weighted rating, the Gasification Group of Projects is projected to produce the greatest benefits as well. Assuming success with the efforts that are required in the continuing demonstration in larger scale kraft mills, and with recognition and development of biomass as a significant renewable energy source, the gasification efforts should result in major beneficial national impacts. It should be noted that other R\&D projects addressing Integrated Gas Turbine Combined Cycle designs and investigation of issues regarding full scale kraft mill implementation will be required to achieve the large benefits available from full implementation of this technology. The Office of Power Technologies is supporting some $R \& D$ work in this area. 


\section{FOREST PRODUCTS INDUSTRY OF THE FUTURE PORTFOLIO STUDY AND EVALUATION}

\section{Environmental Performance Group Project Evaluations}

The raw and weighted ratings for the projects in the Environmental Performance group are shown in Table 3-3.

\begin{tabular}{|c|l|c|c|}
\hline Project \# & Project Name & $\begin{array}{c}\text { Raw } \\
\text { Rating }\end{array}$ & $\begin{array}{c}\text { Weighted } \\
\text { Rating }\end{array}$ \\
\hline $06-669$ & High Efficiency $\mathrm{ClO}_{2}$ Delignification & 29 & 213 \\
\hline $07-685$ & VOC Control in Kraft Mills & 21 & 151 \\
\hline $08-687$ & Low VOC Drying of Lumber and Wood & 26 & 193 \\
\hline $09-941$ & Mill Designed Bio-Bleaching Technologies & 36 & 277 \\
\hline $10-961$ & Water Removal Using Hydrogels & 20 & 147 \\
\hline $11-1150$ & Use of Residual Solids in Concrete & 20 & 144 \\
\hline $12-1151$ & $\begin{array}{l}\text { Low Temperature Plasma Technologies for } \\
\text { Treating VOC Emissions }\end{array}$ & 32 & 236 \\
\hline $13-1152$ & $\begin{array}{l}\text { Control of Emissions from Wood Waste Burners } \\
\text { and Wood Dryers }\end{array}$ & 29 & 208 \\
\hline $14-1154$ & $\begin{array}{l}\text { NPE Removal using Functionalized Monolayers on } \\
\text { Mesoporous Supports }\end{array}$ & 26 & 191 \\
\hline
\end{tabular}

Table 3-3

Environmental Performance Group Project Ratings

The weighted ratings of the projects in the Environmental Performance group ranged from a low of 144 to a high of 277 with a group average of 196 for the nine projects that were evaluated. Within this group, there were no evaluation parameters that showed raw rating averages in excess of 4.0 on a scale of 0.0 to 5.0. The evaluation parameters, "Sustained Forest Resource Management", "Recycled Wood and Paper Materials", and "Alternate Uses for Biomass" showed the lowest raw rating averages ( $<1.0$ on a scale of 0.0 to 5.0 ).

The projects in the Environmental Performance group fall into two primary areas of emphasis-improvements to the bleach process and reduction of VOC and HAP emissions. Of the nine projects reviewed in this effort, three were concerned with the bleaching process and four were related to air emissions.

\section{Sustainable Forestry Group Project Evaluations}

The results of the evaluations of the projects in the Sustainable Forestry group are shown in Table 3-4.

\begin{tabular}{|c|l|c|c|}
\hline Project \# & Project Name & $\begin{array}{c}\text { Raw } \\
\text { Rating }\end{array}$ & $\begin{array}{c}\text { Weighted } \\
\text { Rating }\end{array}$ \\
\hline 15-None & Effects of Fertilization and Competition Control & 37 & 280 \\
\hline $16-677$ & Model-Based Diagnosis of Soil Limitations & 30 & 224 \\
\hline $17-681$ & Marker-Aided Selection Methods & 39 & 288 \\
\hline $18-758$ & Molecular Physiology Allocation in Poplar & 40 & 298 \\
\hline $19-794$ & $\begin{array}{l}\text { Dominant Negative Mutations of Floral Homeotic } \\
\text { Species }\end{array}$ & 40 & 297 \\
\hline $20-795$ & Pine Gene Discovery Project & 41 & 303 \\
\hline
\end{tabular}

Table 3-4

Sustainable Forestry Group Project Ratings 


\section{FOREST PRODUCTS INDUSTRY OF THE FUTURE PORTFOLIO STUDY AND EVALUATION}

The weighted ratings of the projects in the Sustainable Forestry group ranged from a low of 224 to a high of 303 with a group average of 282 for the six projects that were evaluated. Within this group, the evaluation parameters "Sustained Forest Resource Management", "Technology Champion", "Scientific Insights Derived from the Project", and Risk/Benefit Ratio" showed the highest raw rating averages ( $>4.0$ on a scale of 0.0 to 5.0 ). The "Recycled Wood and Paper Materials" evaluation parameter showed the lowest raw rating average $(<1.0$ on a scale of 0.0 to 5.0$)$.

Generally the Sustainable Forestry Group projects reviewed were all given above average ratings because they involve solid fundamental research that offers many potential benefits for the industry and for society as a whole. All of these projects have consistently high ratings except in the areas of energy performance, improved environmental performance, biomass use alternatives, and in the recycling of wood and paper materials. Sustainable forestry would appear to be in conflict with recycling, but when one considers the many uses of wood combined with the potential of new, engineered wood products, then sustainable forestry plays a key role in the long-term objectives of both the industry and the DOE.

Even though these projects have high ratings, they all have very low energy benefit projections as compared to the other projects reviewed in this report. High ratings with low energy benefits are a function of the ratings system used and the weighting given to each parameter of the Project Evaluation system. The low energy benefits that were estimated probably result from the fundamental nature of this research. Although it is easy to envision that the potential benefits from genetics and soils research will be immense, equating those benefits to energy and cost savings is very difficult. Historically foresters and forest researchers tend to be very conservative in their projections, most likely because of the long cycles between planting and harvesting. This conservative tendency combined with the fundamental nature of much of this research results in very conservative, low estimates for energy benefits. By contrast many of the projects in other technology groups that were considered in this study have extremely optimistic (in some cases overly optimistic) estimates for energy savings and project benefits. If accurately forecasting the future were possible, the sustainable forestry portfolio of projects might prove to be as significant and beneficial as many of these other projects.

\section{Improved Capital Effectiveness Group Project Evaluations}

The results of the evaluations of the projects in the Improved Capital Effectiveness group are shown in Table 3-5.

\begin{tabular}{|l|l|c|c|}
\hline Project \# & Project Name & $\begin{array}{c}\text { Raw } \\
\text { Rating }\end{array}$ & $\begin{array}{c}\text { Weighted } \\
\text { Rating }\end{array}$ \\
\hline $21-1481$ & Lateral Corrugator & 11 & 85 \\
\hline $22-1482$ & Improved Dryer and Press Efficiencies & 30 & 221 \\
\hline $23-1483$ & Directed Green Liquor Pulping & 30 & 241 \\
\hline $24-1484$ & High-Capacity Gas-Fired Dryer & 21 & 155 \\
\hline $25-1485$ & Continuous Displacement Dewatering & 32 & 241 \\
\hline $26-1486$ & Borate Autocausticizing & 32 & 238 \\
\hline $27-1487$ & Fast Curing of Wood Composites & 33 & 246 \\
\hline
\end{tabular}

Table 3-5

Improved Capital Effectiveness Group Project Ratings 


\section{FOREST PRODUCTS INDUSTRY OF THE FUTURE}

PORTFOLIO STUDY AND EVALUATION

The weighted ratings of the projects in the Improved Capital Effectiveness group of projects ranged from a low of 85 to a high of 246 with a group average of 204 for the seven projects that were evaluated. Within this group, the evaluation parameter "Economic Attractiveness showed the highest raw rating average (>4.0 on a scale of 0.0 to 5.0). The "Sustained Forest Resource Management", "Recycled Wood and Paper Materials", and "Alternate Uses for Biomass" evaluation parameters showed the lowest raw rating averages $(<1.0$ on a scale of 0.0 to 5.0 ).

This group, with two exceptions demonstrated a remarkable consistency in the weighted ratings, with five of the seven projects rated between 221 and 246 . The two "outliers", Lateral Corrugator and High Capacity Gas-Fired Dryer, with weighted ratings of 85 and 155 respectively, fell well below the group average. Taken as a whole, the projects in this group rated lowest in the Sustained Forest Resource Management, Recycled Wood and Paper Materials, and Alternate Uses for Biomass evaluation parameters. The group was fairly balanced across the other parameters with Energy Performance and Economic Attractiveness showing the highest ratings.

While the projects reviewed under the Capital Effectiveness group all deal with important technical issues, many projects in the group attempt to solve the problem of capital effectiveness by trying to increase process throughput without significantly increasing capital costs. This approach promotes incremental improvement solutions, promoting the biggest and fastest projects, with their high capital intensity, in order to maintain a competitive advantage. While this approach may result in reduced capital per ton of product numbers, overall capital expenditures continue to rise. A broader perspective that includes the consideration of breakthrough technologies in the capital effectiveness aspects of new processes, new devices and/or scientific insights into equipment or processes derived as a result of the Agenda 2020 program might produce additional solutions to the capital effectiveness problem.

\section{Recycling Group Project Evaluations}

The results of the evaluations of the projects in the Recycling group are shown in Table 3-6.

\begin{tabular}{|c|l|c|c||}
\hline Project \# & Project Name & $\begin{array}{c}\text { Raw } \\
\text { Rating }\end{array}$ & $\begin{array}{c}\text { Weighted } \\
\text { Rating }\end{array}$ \\
\hline $28-772$ & Acoustic Separation Technology & 23 & 175 \\
\hline $29-944$ & Easily Removable Cationic PSAs & 35 & 254 \\
\hline $30-945$ & Replacing Chemicals in Recycle Mills & 36 & 265 \\
\hline $31-1198$ & Surfactant Spray to Improve Flotation De-Inking & 30 & 222 \\
\hline
\end{tabular}

Table 3-6

Recycling Group Project Ratings

The weighted ratings of the projects in the Recycling group of projects ranged from a low of 175 to a high of 265 with a group average of 229 for the four projects that were evaluated. Within this group, the evaluation parameters "Size and Extent of Market for the Technology" and "Economic Attractiveness" showed the highest raw rating averages ( $>4.0$ on a scale of 0.0 to 5.0). The "Sustained Forest Resource Management" and "Alternate Uses for Biomass" evaluation parameters showed the lowest raw rating averages $(<1.0$ on a scale of 0.0 to 5.0). The weighted ratings for these projects are clustered in the middle of all the projects reviewed. The average rating for this group is virtually the same as that for all the projects reviewed, but the variance is much less. 


\section{FOREST PRODUCTS INDUSTRY OF THE FUTURE}

PORTFOLIO STUDY AND EVALUATION

The very successful Replacing Chemicals in Recycle Mills with Mechanical Alternatives project is moving forward with several mill trials and clear support from an equipment vendor and from industry. The Surfactant Spray project to improve flotation de-inking is very promising and will soon move to pilot scale testing. The Acoustic Separation Technology project received the lowest rating of the group. In this case, as the scale of the technology was increased from lab trials to demonstration project size, the transducers selected for development proved to be unreliable. The Synthesis, Characterization, and Application of Water-soluble and Easily Removable Pressure Sensitive Adhesives (PSAs) project is a successful research project. It has sponsorship and appears to be moving forward, although it has competition from the other projects in this portfolio.

\section{Sensors and Controls Group Project Evaluations}

The results of the evaluations of the projects in the Sensors and Controls group are shown in Table 3-7.

\begin{tabular}{|c|l|c|c|}
\hline Project \# & Project Name & $\begin{array}{c}\text { Raw } \\
\text { Rating }\end{array}$ & $\begin{array}{c}\text { Weighted } \\
\text { Rating }\end{array}$ \\
\hline $\begin{array}{c}1158 / 699 \\
33-827\end{array}$ & $\begin{array}{l}\text { Deed Stock-Product/Field Mobile NIR } \\
\text { of Paper Weight }\end{array}$ & 41 & 293 \\
\hline $34-975$ & On-Line Fluidics Controlled Headbox & 6 & 44 \\
\hline $35-1157$ & $\begin{array}{l}\text { Guided Acoustic Wave Monitoring of Corrosion \& } \\
\text { Erosion in Recovery Boiler Tubing }\end{array}$ & 22 & 161 \\
\hline $36-1491$ & Wireless Microwave Wood Moisture Measurement & 30 & 222 \\
\hline $37-1492$ & CFD Modeling of Black Liquor Nozzle Design & 29 & 210 \\
\hline
\end{tabular}

Table 3-7

Sensors and Controls Group Project Ratings

The weighted ratings of the projects in the Sensors and Controls group of projects ranged from a low of 44 to a high of 257 with a group average of 198 for the six projects that were evaluated. Within this group, there were no evaluation parameters that showed raw rating averages in excess of 4.0 on a scale of 0.0 to 5.0. The "Sustained Forest Resource Management", "Recycled Wood and Paper Materials", and "Alternate Uses of Biomass" evaluation parameters showed the lowest raw rating averages $(<1.0$ on a scale of 0.0 to 5.0).

The Sensors and Controls group produced the widest range of weighted ratings among all of the groups of projects that were evaluated. The Field Mobile NIR project received a very high rating while the On-line Basis Weight Sensor Project received the lowest rating. The balance of the projects clustered in between. The Field Mobile NIR project is exciting and promising technology because it offers the ability to predict wood strength characteristics and properties prior to harvesting in the woods or prior to machining at the mill and it appears to be relatively inexpensive technology. Once this NIR technology matures, it may well provide much greater benefits than are currently envisioned.

The On Line Fluidics Controlled Headbox also is a very attractive project. It offers reasonable energy savings and, potentially, a $5 \%$ to $10 \%$ reduction in the pulp required for producing the same strength linerboard. As a group, these projects are all well conceived 


\section{FOREST PRODUCTS INDUSTRY OF THE FUTURE PORTFOLIO STUDY AND EVALUATION}

for this technology area of research and development. Even the lowest ranked project, the On Line Basis Weight Sensor, is conceptually very promising. It was originally anticipated that this project would rate much higher, however, the R\&D performed to date has proven that the sensing and data gathering technology selected for this project is too slow to meet the response characteristics necessary for control of high speed paper machines.

Because the paper industry has sophisticated electronic control systems in virtually all of the mills operating in the US today, the ability to make process improvements and reduce energy consumption through improvements in sensors and controls technology offers significant potential benefits in terms of energy savings and other industry benefits.

\subsection{Stages of Development of Projects}

Each of the thirty-seven projects considered in this study was characterized by its current Stage of Development using the definitions discussed in Section 2 of this report. None of these projects were judged to have reached Stage 6 (Commercial Deployment) which is consistent with the nature of the projects that were selected for this study. The current Stages of Development for these projects are arranged by technology group and presented in the tables below.

\section{Energy Performance Group Projects Stages of Development}

The Stages of Development for the projects in the Energy Performance group are shown in Table 3-8.

\begin{tabular}{|c|l|c|}
\hline Project \# & Project Name & $\begin{array}{c}\text { Stage of } \\
\text { Development }\end{array}$ \\
\hline $01-785$ & Multiport Cylinder Dryer & 3 \\
\hline $02-933$ & Methane DeNO & 5 \\
\hline $03-993$ & Gasification Group of Projects & 1 to $5^{7}$ \\
\hline $04-1110$ & Intermediate Sized Entrained Particles & 2 \\
\hline $05-1166$ & 3-D Characterization of Structure & 1 \\
\hline
\end{tabular}

Table 3-8

Energy Performance Group Stages of Development

The projects in the Energy Performance group are fairly well distributed among the Stages of Development with projects in Stage 1 (Basic/Fundamental Research), Stage 2 (Applied Research), Stage 3 (Process or Equipment Development/Improvement), and two projects in the Stage 4 to Stage 5 range (Technology Scale-up/Equipment Improvement and Technology/Equipment Demonstration). The Big Island Black Liquor Gasification is a demonstration/development project and the Methane DeNOX Reburning project is late in the demonstration stage and is moving into commercialization. A small gap exists in that no projects evaluated in this group were found to be in Stage 2 - Applied Research.

\footnotetext{
${ }^{7}$ This range represents gasification projects in addition to the three that were considered in this study.
} 


\section{FOREST PRODUCTS INDUSTRY OF THE FUTURE}

PORTFOLIO STUDY AND EVALUATION

\section{Environmental Performance Group Projects Stages of Development}

The Stages of Development for the projects in the Environmental Performance group are shown in Table 3-9.

\begin{tabular}{|c|l|c|}
\hline Project \# & Project Name & $\begin{array}{c}\text { Stage of } \\
\text { Development }\end{array}$ \\
\hline $06-669$ & High Efficiency $\mathrm{ClO}_{2}$ Delignification & 1.5 \\
\hline $07-685$ & VOC Control in Kraft Mills & 2 \\
\hline $08-687$ & Low VOC Drying of Lumber and Wood & 3 \\
\hline $09-941$ & Mill Designed Bio-Bleaching Technologies & 1.5 \\
\hline $10-961$ & Water Removal Using Hydrogels & 1.5 \\
\hline $11-1150$ & Use of Residual Solids in Concrete & 2 \\
\hline $12-1151$ & $\begin{array}{l}\text { Low Temperature Plasma Technologies for } \\
\text { Treating VOC Emissions }\end{array}$ & 3.5 \\
\hline $13-1152$ & $\begin{array}{l}\text { Control of Emissions from Wood Waste Burners } \\
\text { and Wood Dryers }\end{array}$ & 3 \\
\hline $14-1154$ & $\begin{array}{l}\text { NPE Removal using Functionalized Monolayers on } \\
\text { Mesoporous Supports }\end{array}$ & 1.5 \\
\hline
\end{tabular}

Table 3-9

Environmental Performance Group Stages of Development

Six of the nine projects in the Environmental Performance group fall within the range of Stage 1 - Basic/Fundamental Research to Stage 2 (Applied Research). Two of the remaining three projects fall in Stage 3 (Process or Equipment Development/Improvement) and the other falls between Stage 3 and Stage 4 (Technology Scale-up/Equipment Improvement). There were no projects evaluated in this group that fell in Stage 4 or above.

\section{Sustainable Forestry Group Projects Stages of Development}

The Stages of Development for the projects in the Sustainable Forestry group are shown in Table 3-10.

\begin{tabular}{|c|l|c|}
\hline Project \# & Project Name & $\begin{array}{c}\text { Stage of } \\
\text { Development }\end{array}$ \\
\hline 15-None & Effects of Fertilization and Competition Control & 3 \\
\hline $16-677$ & Model-Based Diagnosis of Soil Limitations & 3 \\
\hline $17-681$ & Marker-Aided Selection Methods & 2 \\
\hline $18-758$ & Molecular Physiology Allocation in Poplar & 1 \\
\hline $19-794$ & $\begin{array}{l}\text { Dominant Negative Mutations of Floral Homeotic } \\
\text { Species }\end{array}$ & 2 \\
\hline $20-795$ & Pine Gene Discovery Project & 1 \\
\hline
\end{tabular}

Table 3-10

Sustainable Forestry Group Stages of Development

Only two of these projects, the Effects of Fertilization and Competition Control project and the Model-Based Diagnosis of Soil Limitations project have reached Stage 3 (Process or Equipment Development/Improvement). Considerable time and effort will be required to bring the other projects to the implementation phase and the benefits of the genetic research involved in these other projects will probably not be realized for many years to come, in many cases beyond the year 2020 . 


\section{FOREST PRODUCTS INDUSTRY OF THE FUTURE}

PORTFOLIO STUDY AND EVALUATION

\section{Improved Capital Effectiveness Group Projects Stages of Development}

The Stages of Development for the projects in the Improved Capital Effectiveness group are shown in Table 3-11.

\begin{tabular}{|c|l|c|}
\hline Project \# & Project Name & $\begin{array}{c}\text { Stage of } \\
\text { Development }\end{array}$ \\
\hline $21-1481$ & Lateral Corrugator & 3 \\
\hline $22-1482$ & Improved Dryer and Press Efficiencies & 2 \\
\hline $23-1483$ & Directed Green Liquor Pulping & 1.5 \\
\hline $24-1484$ & High-Capacity Gas-Fired Dryer & 3 \\
\hline $25-1485$ & Continuous Displacement Dewatering & 3 \\
\hline $26-1486$ & Borate Autocausticizing & 3 \\
\hline $27-1487$ & Fast Curing of Wood Composites & 3 \\
\hline
\end{tabular}

Table 3-11

Improved Capital Effectiveness Group Stages of Development

Five of the seven projects in the Improved Capital Effectiveness group were concentrated in Stage 3 (Process or Equipment Development/Improvement). Of the other two, one was between Stage 1 (Basic/Fundamental Research) and Stage 2 (Applied Research) and the other was in Stage 2. There were no projects in this group in Stages 4 through 6, the Technology Scale-up, Demonstration, or Commercialization stages.

\section{Recycling Group Projects Stages of Development}

The Stages of Development for the projects in the Recycling group are shown in Table 3-12.

\begin{tabular}{|c|l|c|}
\hline Project \# & Project Name & $\begin{array}{c}\text { Stage of } \\
\text { Development }\end{array}$ \\
\hline $28-772$ & Acoustic Separation Technology & 2.5 \\
\hline $29-944$ & Easily Removable Cationic PSAs & 4 \\
\hline $30-945$ & Replacing Chemicals in Recycle Mills & 5 \\
\hline $31-1198$ & Surfactant Spray to Improve Flotation De-Inking & 3 \\
\hline
\end{tabular}

Table 3-12

Recycling Group Stages of Development

The projects in the Recycling group were spread between Stage 2 (Applied Research) and Stage 5 (Technology/Equipment Demonstration). There were no projects in this group in Stage 1 (Basic/Fundamental Research). Although the smallest group to be evaluated, this group better represents the full range of the Stages of Development than any of the other technology groups that were evaluated. Clearly, the projects selected in this group had good potential for early success. If the Acoustic Separation Technology had been more fortunate in the development of transducers for the project, all of these projects would be highly successful. 


\section{FOREST PRODUCTS INDUSTRY OF THE FUTURE}

PORTFOLIO STUDY AND EVALUATION

\section{Sensors and Controls Group Projects Stages of Development}

The Stages of Development for the projects in the Sensors and Controls group are shown in Table 3-13.

\begin{tabular}{|c|l|c|}
\hline Project \# & Project Name & $\begin{array}{c}\text { Stage of } \\
\text { Development }\end{array}$ \\
\hline $\begin{array}{c}32- \\
1158 / 699\end{array}$ & Feed Stock-Product/Field Mobile NIR & 5 \\
\hline $33-827$ & $\begin{array}{l}\text { Distributed Web Sensor for On-Line Measurement } \\
\text { of Paper Weight }\end{array}$ & 2 \\
\hline $34-975$ & On-Line Fluidics Controlled Headbox & 3 \\
\hline $35-1157$ & $\begin{array}{l}\text { Guided Acoustic Wave Monitoring of Corrosion \& } \\
\text { Erosion in Recovery Boiler Tubing }\end{array}$ & 3 \\
\hline $36-1491$ & Wireless Microwave Wood Moisture Measurement & 2.5 \\
\hline $37-1492$ & CFD Modeling of Black Liquor Nozzle Design & 2 \\
\hline
\end{tabular}

Table 3-13

Sensors and Controls Group Stages of Development

Five of the six projects in the Sensors and Controls group were concentrated between Stage 2 (Applied Research) and Stage 3 (Process or Equipment Development/Improvement). One project was in Stage 5 (Technology/Equipment Demonstration). There were no projects in this group in Stage 1 (Basic/Fundamental Research) or in Stage 4 (Technology Scaleup/Equipment Improvement).

The Field Mobile NIR project could probably qualify as Stage 1 or Stage 2 research, but its success and the resulting industry interest seems to have this technology on a fast track toward implementation. In general, the projects in this group are direct application projects that don't involve as much fundamental research as many of the other projects that were evaluated. Therefore, they may offer the potential for implementation and significant market penetration much earlier than year 2020 .

\section{Progression through Stages of Development}

The Stages of Development discussed above were based on the current status of the projects that were evaluated. There are some instances wherein projects entered the Agenda 2020 R\&D program at earlier stages and subsequently progressed to the current stage. There are other instances where projects are currently at their entry stage. In order to present these data, the Table 3-14 was developed.

Table 3-14 indicates that nineteen of the thirty-seven projects that were evaluated are in their entry Stage of Development, seven have progressed somewhat, and eleven have progressed from one stage to another or more. The greatest progression was registered by Project 29-944 (Easily Removable Cationic PSAs) with a progression of three full stages from its entry into the Agenda 2020 program as a Basic/Fundamental Research project to its current status as a Technology Scale-up/Equipment Improvement project. Five other projects, 03-933 (Gasification Group of Projects), 12-1151 (Low Temperature Plasma Technologies for Treating VOC Emissions), 13-1152 (Control of Emissions from Wood Waste Burners and Wood Dryers), 30-945 (Replacing Chemicals in Recycle Mills), and 32$1158 / 699$ (Feed Stock-Product/Field Mobile NIR) also show a progression through more than one stage. 


\section{FOREST PRODUCTS INDUSTRY OF THE FUTURE \\ PORTFOLIO STUDY AND EVALUATION}

Approximately half of the projects evaluated in this study show progress beyond their initial entry stages of development. This would indicate a significant level of progress in general, particularly in view of the fact that several projects are comparatively recent awards that have not had sufficient time to register progress of the magnitude required to move from one stage of development to another. This explains why the Capital Effectiveness group of projects is the only task group wherein none of the projects evaluated appear to have made progress. 


\section{FOREST PRODUCTS INDUSTRY OF THE FUTURE} PORTFOLIO STUDY AND EVALUATION

\begin{tabular}{|c|c|c|c|}
\hline $\begin{array}{c}\text { Project } \\
\#\end{array}$ & Title & $\begin{array}{c}\text { Initial } \\
\text { Stage of } \\
\text { Development }\end{array}$ & $\begin{array}{c}\text { Current } \\
\text { Stage of } \\
\text { Development }\end{array}$ \\
\hline $01-785$ & Multiport Cylinder Dryer & 2 & 3 \\
\hline $02-933$ & Methane DeNO & 4 & 5 \\
\hline $03-993$ & Gasification Group of Projects & 1 & 1 to $5^{8}$ \\
\hline 04-1110 & Intermediate Sized Entrained Particles & 2 & 2 \\
\hline $05-1166$ & 3-D Characterization of Structure & 1 & 1 \\
\hline $06-669$ & High Efficiency $\mathrm{ClO}_{2}$ Delignification & 1 & 1.5 \\
\hline $07-685$ & VOC Control in Kraft Mills & 2 & 2 \\
\hline $08-687$ & Low VOC Drying of Lumber and Wood & 2.5 & 3 \\
\hline $09-941$ & Mill Designed Bio-Bleaching Technologies & 1 & 1.5 \\
\hline $10-961$ & Water Removal Using Hydrogels & 1 & 1.5 \\
\hline $11-1150$ & Use of Residual Solids in Concrete & 2 & 2 \\
\hline $12-1151$ & $\begin{array}{l}\text { Low Temperature Plasma Technologies for Treating } \\
\text { VOC Emissions }\end{array}$ & 2 & 3.5 \\
\hline $13-1152$ & $\begin{array}{l}\text { Control of Emissions from Wood Waste Burners and } \\
\text { Wood Dryers }\end{array}$ & 1 & 3 \\
\hline $14-1154$ & $\begin{array}{l}\text { NPE Removal using Functionalized Monolayers on } \\
\text { Mesoporous Supports }\end{array}$ & 1 & 1.5 \\
\hline 15-None & Effects of Fertilization and Competition Control & 3 & 3 \\
\hline $16-677$ & Model-Based Diagnosis of Soil Limitations & 3 & 3 \\
\hline $17-681$ & Marker-Aided Selection Methods & 1 & 2 \\
\hline $18-758$ & Molecular Physiology Allocation in Poplar & 1 & 1 \\
\hline $19-794$ & $\begin{array}{l}\text { Dominant Negative Mutations of Floral Homeotic } \\
\text { Species }\end{array}$ & 1 & 2 \\
\hline $20-795$ & Pine Gene Discovery Project & 1 & 1 \\
\hline $21-1481$ & Lateral Corrugator & 3 & 3 \\
\hline $22-1482$ & Improved Dryer and Press Efficiencies & 2 & 2 \\
\hline 23-1483 & Directed Green Liquor Pulping & 1.5 & 1.5 \\
\hline 24-1484 & High-Capacity Gas-Fired Dryer & 3 & 3 \\
\hline $25-1485$ & Continuous Displacement Dewatering & 3 & 3 \\
\hline $26-1486$ & Borate Autocausticizing & 3 & 3 \\
\hline $27-1487$ & Fast Curing of Wood Composites & 2 & 3 \\
\hline $28-772$ & Acoustic Separation Technology & 2 & 2.5 \\
\hline $29-944$ & Easily Removable Cationic PSAs & 1 & 4 \\
\hline $30-945$ & Replacing Chemicals in Recycle Mills & 3 & 5 \\
\hline $31-1198$ & Surfactant Spray to Improve Flotation De-Inking & 3 & 3 \\
\hline $32-1158 / 699$ & Feed Stock-Product/Field Mobile NIR & 3 & 5 \\
\hline $33-827$ & $\begin{array}{l}\text { Distributed Web Sensor for On-Line Measurement of } \\
\text { Paper Weight }\end{array}$ & 2 & 2 \\
\hline $34-975$ & On-Line Fluidics Controlled Headbox & 2 & 3 \\
\hline $35-1157$ & $\begin{array}{l}\text { Guided Acoustic Wave Monitoring of Corrosion \& } \\
\text { Erosion in Recovery Boiler Tubing }\end{array}$ & 3 & 3 \\
\hline $36-1491$ & Wireless Microwave Wood Moisture Measurement & 2 & 2.5 \\
\hline $37-1492$ & CFD Modeling of Black Liquor Nozzle Design & 2 & 2 \\
\hline
\end{tabular}

Table 3-14

Progression through Stages of Development by Project

\footnotetext{
${ }^{8}$ This range represents gasification projects in addition to the three that were considered in this study.
} 


\section{FOREST PRODUCTS INDUSTRY OF THE FUTURE PORTFOLIO STUDY AND EVALUATION}

\subsection{Energy Savings}

GPRA spreadsheets provided the data used in this study regarding energy and cost savings. In general, estimates of capital and non-energy variable costs (or other payback terms data) for the projects evaluated in this study did not appear in the GPRA spreadsheets. Provisions for estimating these data are included in the spreadsheet format and instructions (Appendix B).

It was also noted that energy savings attributable to use of renewable energy sources and waste energy are not included in the calculation of total primary energy displaced. The renewable, waste, and other energy cost formula essentially treats those energy sources as zero cost in the GPRA spreadsheet calculation.

\section{Energy Performance Group Projects GPRA Energy Savings Data}

Potential energy savings for projects in the Energy Performance Group are shown in Table 3-15.

\begin{tabular}{|c|l|c|}
\hline \hline Project \# & Project Name & $\begin{array}{c}\text { Total Primary Energy } \\
2030\left(10^{12} \text { BTUs }\right)\end{array}$ \\
\hline $01-785$ & Multiport Cylinder Dryer & 23.0 \\
\hline $02-933$ & Methane DeNO & 3.7 \\
\hline $03-993$ & Gasification Group of Projects & 2560.0 \\
\hline $04-1110$ & Intermediate Sized Entrained Particles & 92.3 \\
\hline $05-1166$ & 3-D Characterization of Structure & 19.8 \\
\hline
\end{tabular}

Table 3-15

Energy Performance Group Potential Energy Savings

This group of projects targets areas that provide large potential energy savings and as a group demonstrates the greatest potential for energy savings.

The potential energy savings for the Gasification Group of Projects takes credit for all of the savings currently projected for the entire Biomass and Black Liquor Gasification

Demonstration Initiative. These potential savings overwhelm the other projects in the Energy Performance group and all of the projects in the other technology groups as well. However, the magnitude of the estimated savings may not be totally accurate considering that the total current annual energy use in the pulp and paper sector (SIC Code 26 - Paper and Allied Products) of the industry is on the order of 3,000 trillion BTUs. In fact OIT is reassessing the impact of the Gasification Initiative at this time. It should be noted that the Gasification Group of Projects is also the highest rated as demonstrated in Table 3-2.

The next greatest potential energy savings found in this group is for the Intermediate Sized Entrained Particles project, which illustrates the potential benefit of improving existing recovery boiler operations. 


\section{FOREST PRODUCTS INDUSTRY OF THE FUTURE}

PORTFOLIO STUDY AND EVALUATION

\section{Environmental Performance Group Projects GPRA Energy Savings Data}

Potential energy savings for projects in the Environmental Performance Group are shown in Table 3-16.

\begin{tabular}{|c|l|c|}
\hline Project \# & Project Name & $\begin{array}{c}\text { Total Primary Energy } \\
2030\left(10^{12} \mathrm{BTUs}\right)\end{array}$ \\
\hline $06-669$ & High Efficiency $\mathrm{ClO}_{2}$ Delignification & 0.1 \\
\hline $07-685$ & VOC Control in Kraft Mills & 5.8 \\
\hline $08-687$ & Low VOC Drying of Lumber and Wood & 70.3 \\
\hline $09-941$ & Mill Designed Bio-Bleaching Technologies & 43.4 \\
\hline $10-961$ & Water Removal Using Hydrogels & 31.2 \\
\hline $11-1150$ & Use of Residual Solids in Concrete & 38.7 \\
\hline $12-1151$ & $\begin{array}{l}\text { Low Temperature Plasma Technologies for } \\
\text { Treating VOC Emissions }\end{array}$ & 1.4 \\
\hline $13-1152$ & $\begin{array}{l}\text { Control of Emissions from Wood Waste Burners } \\
\text { and Wood Dryers }\end{array}$ & 20.6 \\
\hline $14-1154$ & $\begin{array}{l}\text { NPE Removal using Functionalized Monolayers on } \\
\text { Mesoporous Supports }\end{array}$ & 172.6 \\
\hline
\end{tabular}

Table 3-16

Environmental Performance Group Potential Energy Savings

The focus of the environmental group is not energy savings. However, the table demonstrates that there can be significant potential energy savings associated with environmental performance projects.

The NPE Removal using Functionalized Monolayers on Mesoporous Supports project shows the largest projected energy savings in this group of projects. Because the number stands out, it may be useful to reconsider the assumptions used for this project's estimate of energy savings.

The Low VOC Drying of Lumber and Wood project is an example of a special case where the current process energy consumption is low, but new equipment is expected to be installed to satisfy more stringent environmental emission requirements. This new equipment is projected to consume large quantities of energy. Therefore, the potential energy savings is not in comparison to current energy use but rather represents a savings in comparison to the projected additional energy usage that is expected to result from a stricter environmental requirement.

\footnotetext{
${ }^{9}$ No energy savings data were available for this project therefore an arbitrary energy savings of 0.1 trillion BTUs was assigned so that this data point would show on the Energy vs. Weighted Rating bubble charts.
} 
FOREST PRODUCTS INDUSTRY OF THE FUTURE

PORTFOLIO STUDY AND EVALUATION

\section{Sustainable Forestry Group Projects GPRA Energy Savings Data}

Potential energy savings for projects in the Sustainable Forestry Group are shown in Table 3-17.

\begin{tabular}{|c|l|c|}
\hline Project \# & Project Name & $\begin{array}{c}\text { Total Primary Energy } \\
2030\left(10^{12} \text { BTUs }\right)\end{array}$ \\
\hline $15-$ None & Effects of Fertilization and Competition Control & 2.8 \\
\hline $16-677$ & Model-Based Diagnosis of Soil Limitations & 2.8 \\
\hline $17-681$ & Marker-Aided Selection Methods & 0.1 \\
\hline $18-758$ & Molecular Physiology Allocation in Poplar & 2.8 \\
\hline $19-794$ & $\begin{array}{l}\text { Dominant Negative Mutations of Floral Homeotic } \\
\text { Species }\end{array}$ & 0.8 \\
\hline $20-795$ & Pine Gene Discovery Project & 5.1 \\
\hline
\end{tabular}

Table 3-17

Sustainable Forestry Group Potential Energy Savings

The ultimate potential for these projects lies in the ability to produce trees with physical properties tailored to improve the products that are to be produced or to reduce costs within the processes used to produce that product. Since wood is also a viable energy source, sustainable forests represent a long-term renewable energy resource. The forest products industry in general considers the management of sustainable forests as one of the most important objectives for remaining competitive as an industry. The Department of Energy supports sustainable forestry research through several offices, including the Office of Power Technologies (OPT), Office of Transportation Technologies (OTT), as well as OIT. OIT has the specific mission of reducing energy consumption in industrial processes. The constraints in the energy accounting system used only allow OIT to account for potential energy savings associated with industrial processes.

\section{Improved Capital Effectiveness Group Projects GPRA Energy Savings Data}

Potential energy savings for projects in the Improved Capital Effectiveness Group are shown in Table 3-18.

\begin{tabular}{|l|l|c|}
\hline Project \# & Project Name & $\begin{array}{c}\text { Total Primary Energy } \\
2030\left(10^{12} \text { BTUs) }\right.\end{array}$ \\
\hline $21-1481$ & Lateral Corrugator & 26.6 \\
\hline $22-1482$ & Improved Dryer and Press Efficiencies & 109.9 \\
\hline $23-1483$ & Directed Green Liquor Pulping & 27.2 \\
\hline $24-1484$ & High-Capacity Gas-Fired Dryer & 29.8 \\
\hline $25-1485$ & Continuous Displacement Dewatering & 217.0 \\
\hline $26-1486$ & Borate Autocausticizing & 13.8 \\
\hline $27-1487$ & Fast Curing of Wood Composites & 23.6 \\
\hline
\end{tabular}

Table 3-18

Improved Capital Effectiveness Group Potential Energy Savings

\footnotetext{
${ }^{10}$ No energy savings data were available for this project therefore an arbitrary energy savings of 0.1 trillion BTUs was assigned so that this data point would show on the Energy vs. Weighted Rating bubble charts.
} 


\section{FOREST PRODUCTS INDUSTRY OF THE FUTURE}

PORTFOLIO STUDY AND EVALUATION

In process industries, capital equipment improvements are often accompanied by improved energy efficiencies as demonstrated by the projects in the Table 3-18. This table also demonstrates there are significant potential energy savings associated with projects that increase water removal efficiencies.

In some cases these benefits appear to be overstated. As an example, the energy savings projected for the gas-fired dryer are based on a reduced usage of natural gas. However, most mills currently use excess low-pressure steam for drying energy. Consequently, they would have to buy and burn additional natural gas or generate a synthetic gas in order to use this device. Furthermore, they would cease to recover this energy from their lowpressure steam, possibly having to use condensers to reject this heat as "waste" instead. The economic analysis also did not take into account the use of alternative fuels (wood waste, bark, biomass, black liquor, etc.) at the mills where they are available.

\section{Recycling Group Projects GPRA Energy Savings Data}

Potential energy savings for projects in the Recycling Group are shown in Table 3-19.

\begin{tabular}{|c|l|c|}
\hline \hline Project \# & Project Name & $\begin{array}{c}\text { Total Primary Energy } \\
2030\left(10^{12} \text { BTUs }\right)\end{array}$ \\
\hline $28-772$ & Acoustic Separation Technology & 21.1 \\
\hline $29-944$ & Easily Removable Cationic PSAs & 26.9 \\
\hline $30-945$ & Replacing Chemicals in Recycle Mills & 108.0 \\
\hline $31-1198$ & Surfactant Spray to Improve Flotation De-Inking & 481.7 \\
\hline
\end{tabular}

Table 3-19

Recycling Group Potential Energy Savings

The Industry recognizes the social and environmental benefits of using recycled fiber. Table 3-19 demonstrates these types of projects can also have significant potential energy savings. The Surfactant Spray to Improve Flotation De-Inking project reports the largest projected energy savings in this group. Because the number stands out, it may be useful to reconsider the assumptions used for this project estimate.

\section{Sensors and Controls Group Projects GPRA Energy Savings Data}

Potential energy savings for projects in the Sensors and Controls Group are shown in Table 3-20.

\begin{tabular}{|c|l|c|}
\hline Project \# & Project Name & $\begin{array}{c}\text { Total Primary Energy } \\
2030\left(10^{12} \mathrm{BTUs}\right)\end{array}$ \\
\hline $\begin{array}{c}32- \\
1158 / 699\end{array}$ & Feed Stock-Product/Field Mobile NIR & 9.7 \\
\hline $33-827$ & $\begin{array}{l}\text { Distributed Web Sensor for On-Line Measurement } \\
\text { of Paper Weight }\end{array}$ & 26.7 \\
\hline $34-975$ & On-Line Fluidics Controlled Headbox & 97.2 \\
\hline $35-1157$ & $\begin{array}{l}\text { Guided Acoustic Wave Monitoring of Corrosion \& } \\
\text { Erosion in Recovery Boiler Tubing }\end{array}$ & 102.4 \\
\hline $36-1491$ & Wireless Microwave Wood Moisture Measurement & 43.1 \\
\hline $37-1492$ & CFD Modeling of Black Liquor Nozzle Design & 88.3 \\
\hline
\end{tabular}

Table 3-20

Sensors and Controls Group Potential Energy Savings 
Sensors and controls projects generally improve quality and productivity and have the potential for significant economic benefits over and above potential energy savings. However, Table 3-20 demonstrates they can have significant energy savings as well.

The two projects with the greatest potential energy savings illustrate the potential benefit of improving existing recovery boiler operations.

\subsection{Value of the Agenda 2020 Program}

\section{Quantifiable Value of the Agenda 2020 Program}

The energy and cost savings projected on the individual spreadsheets for each of the projects considered in this study were summarized by task group and presented in the stacked barcharts (Figures 3-1 and 3-2) below. These barcharts suggest that the technologies being explored and developed under the Agenda 2020 program could possibly generate energy savings in excess of 2,000 trillion BTUs per year by 2020 and 4,500 trillion BTUs per year by year 2030 . It must be noted that these savings include some accumulation due to overlap among projects. They are also based on the assumption that all of the projects considered will achieve one hundred percent technical success. Therefore, the implied overall impact for these projects is a considerable overstatement of the true potential. It is not practical to remove the redundancy or to develop more accurate estimates for probabilities of technical and commercial success at this time; nonetheless, a substantial level of real contribution is implied for the current portfolio.

The implied cost savings to the Forest Products industry that would be attributable to the projects considered in this study are also impressive. Projected to reach nearly $\$ 20$ billion dollars per year by 2030 , these cost savings are largely a function of the projected energy savings, which dominate the calculations performed in the GPRA spreadsheet. Because of this close linkage with the projected energy savings, these projected cost savings must be recognized as a considerable overstatement as well.

To put these figures in perspective, a benchmark number for the total annual primary energy consumed by the forest products industry was determined from data published by the Energy Information Agency (EIA). ${ }^{11}$ The most recent data published by Standard Industrial Classification (SIC) Codes is for the year 1994. Two SIC Codes best represent the forest products industry, SIC Code 24 (Lumber and Wood Panel) and SIC Code 26 (Paper and Allied Products). The EIA data show that the total annual consumption for SIC Code 24 was 491 trillion BTUs of which 68 trillion BTUs were in the form of purchased electricity. When adjusted for heat rate, the total primary energy consumption for SIC Code 24 becomes 632 trillion BTUs. Similarly, the total energy consumption for SCI Code 26 was 2,665 trillion BTUs of which 223 trillion BTUs were purchased electricity. When adjusted for heat rate, the total primary energy consumption for SIC Code 26 becomes 3128 trillion BTUs. These data indicate a total primary energy consumption for the forest products industry of 3,760 trillion BTUs per year in year 1994. By comparison, the projections cited above would seem to indicate that the energy savings by year 2020 would amount to greater than one half of the total 1994 consumption and would exceed it by year 2030. Even with allowances for modest increases in consumption, it is highly unlikely that actual savings of this magnitude

\footnotetext{
${ }^{11}$ Manufacturing Consumption of Energy 1994
} 


\section{FOREST PRODUCTS INDUSTRY OF THE FUTURE PORTFOLIO STUDY AND EVALUATION}

could be realized. It is clear from this comparison that the simple accumulation of the energy and cost savings estimated on the individual GPRA spreadsheets results in totals that are overstated as noted above. Nevertheless, it is also clear that the energy and cost savings that can be expected from the Agenda 2020 program will have a substantial positive effect.

Several factors must be considered when drawing conclusions from Figures 3-1 and 3-2. First, the data represent only thirty-seven of the one hundred and five DOE supported projects initiated to date under the Agenda 2020 program. These thirty-seven projects were selected because they were thought to have the greatest potential impact on the program. Second, the methodology that has been adopted by DOE's Office of Energy Efficiency and Renewable Energy (EERE) for these projections assumes that every project will be technologically successful and that the technology will be successfully commercialized using a number of different market penetration assumptions. Third, the estimates of energy savings, market penetration factors, etc. rely upon the estimates provided by the Pls and these were not subjected to comprehensive industry review and analysis. Fourth, the summation methodology provides opportunities for the possible double counting of benefits in cases of similar competing technologies. Fifth, savings dollars are expressed in future year dollars for future benefits. Sixth, some of the projects are in the early R\&D stages and the validity of the estimates of their benefits is highly speculative.

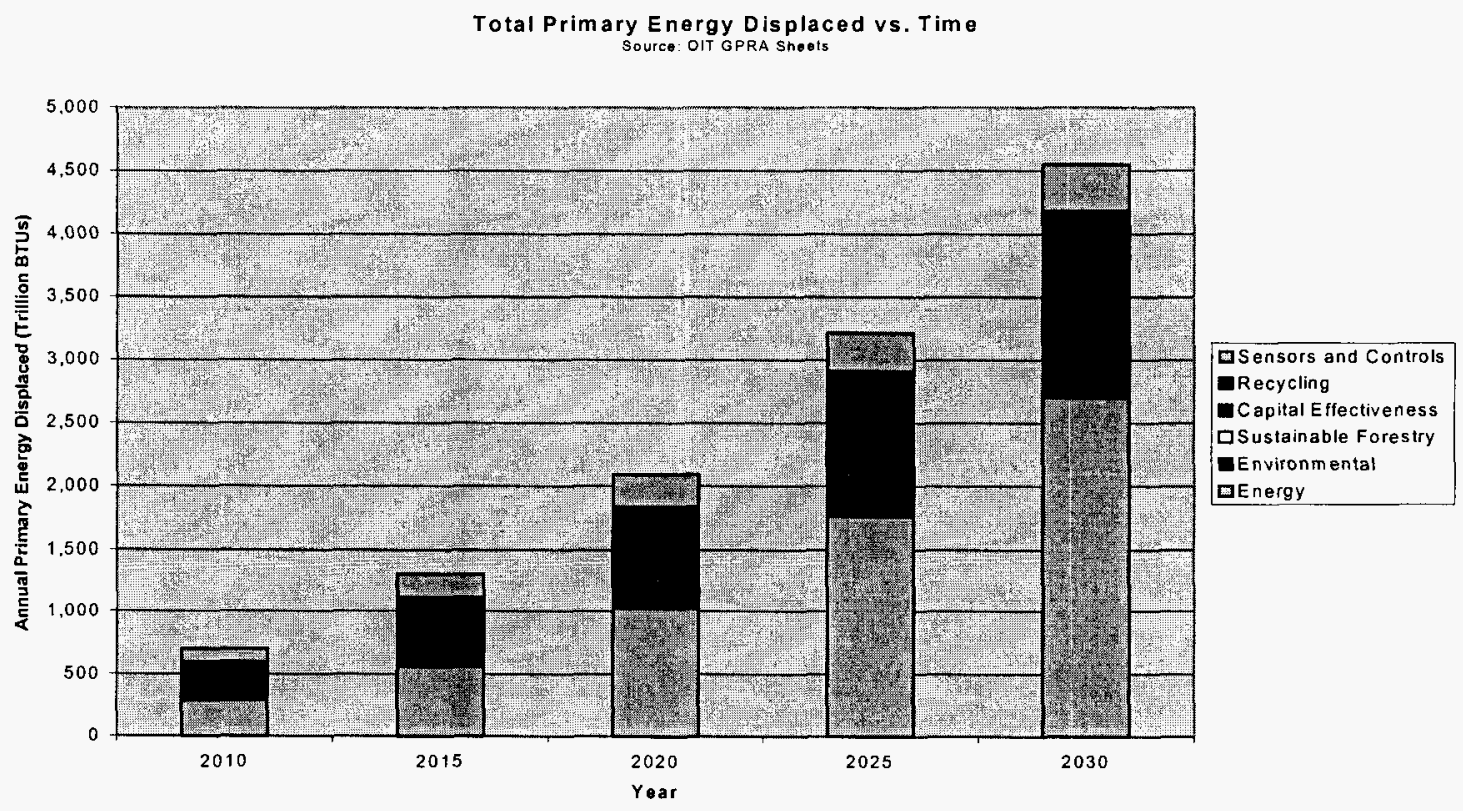

Figure $3-1^{12}$

\footnotetext{
${ }^{12}$ The energy displacement indicated include overlap among projects and the assumption of $100 \%$ technical success, therefore they considerably overstate the true potential.
} 


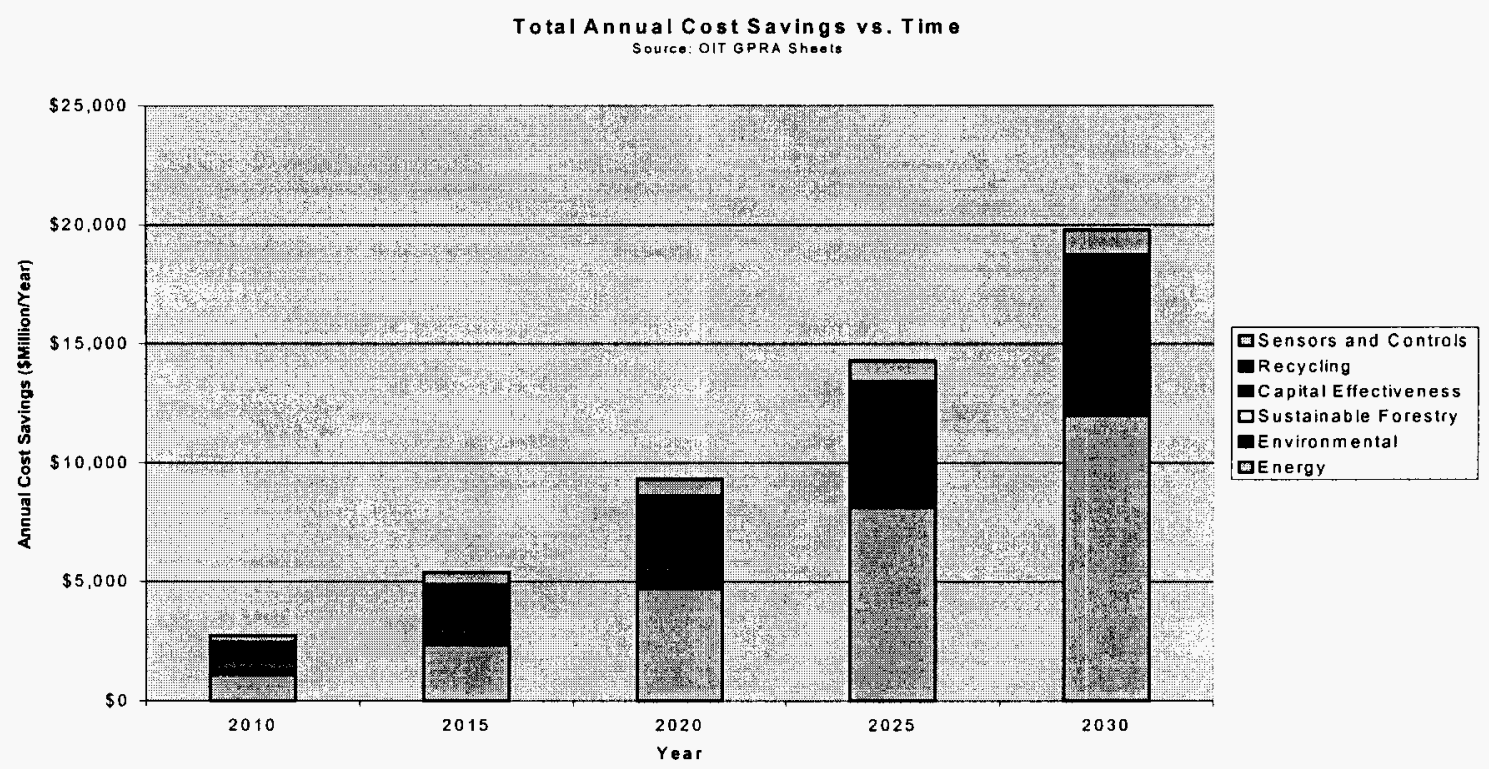

Figure $3-2^{13}$

Even with the above precautions and factors taken into account, the magnitude of the potential energy and cost savings represented in these barcharts indicates a program of significant value to the forest products industry and to the nation as a whole. The program is intended to focus on pre-competitive R\&D projects and, already, a number of these projects are approaching commercial status. In the few short years since its inception, the Agenda 2020 program is expected to make remarkable progress in tangible, quantifiable terms. In addition to these potential benefits, the conduct of the program itself is providing further benefits of a systemic nature that may prove to be of even greater significance.

\section{Systemic Value of the Agenda 2020 Program}

In addition to the quantifiable benefits discussed above, the Agenda 2020 program has fostered several items of significant, albeit non-quantifiable value to the Forest Products industry. First, there are many R\&D projects in the portfolio that were made possible by the shared risk aspects of the Agenda 2020 program-the Black Liquor Gasification Project is a good example. Second, the program has served as a catalyst to bring the industry members together with a unifying focus to collaborate on the definition of needs and establishment of priorities for the economic health of the industry and the nation. Third, the program has facilitated the industry's efforts to clarify and focus the technology R\&D effort. Fourth, the program has stimulated the process of defining the criteria and procedures necessary to effectively evaluate the worth of R\&D projects and establish the diversity of projects necessary to maintain a robust program. Fifth, the degree of collaboration that has developed between the industry, the government, and research organizations (including universities and national laboratories) fosters an environment that promises more effective problem solving with win-win outcomes in the future.

\footnotetext{
${ }^{13}$ The cost savings indicated include overlap among projects and the assumption of $100 \%$ technical success, therefore they considerably overstate the true potential.
} 


\section{FOREST PRODUCTS INDUSTRY OF THE FUTURE PORTFOLIO STUDY AND EVALUATION}

\subsection{Potential Economic Impacts of the Projects}

One of the goals of this study was to identify the potential economic impacts of the projects that were evaluated in terms of reduced capital intensity, productivity improvements, reduced environmental costs, and safety improvements. Although the GPRA spreadsheets provide features for including estimates of capital and non-energy variable costs and assumptions regarding payback terms and other pertinent economic factors, these data were not available. Similarly, the data required to assess the economic impacts of these projects in terms of environmental costs and safety improvements were not available. Reasonable evaluations of the economic impacts of these projects were precluded.

In conjunction with the estimation of capital and non-energy variable costs, the understanding of economic impacts and the capital effectiveness aims of the industry could be enhanced by employing recognized value-engineering methods to systematically evaluate estimates of cost, worth, value, and benefits during the project selection process. The development of these methods should involve organizations such as TAPPI Engineering and the Construction Industry Institute (CII) to share their best practices for improving effectiveness in capital investment programs.

\subsection{The R\&D Process}

The process for solicitations and project reviews involves crosscutting jurisdictions at the task group level, however, the intentions of these crosscutting efforts do not always filter down to the PIs. An emphasis on an integrated, problem-oriented focus for new R\&D projects might provide a more directed focus for the researchers regarding the problem being addressed and should make it easier to identify the associated benefits to the industry. This is the way that the industry appears to be moving in the evolution of their proposed New Technology Strategy. A forum that would facilitate the exchange of information between researchers and the industry (prior to formal solicitations) regarding needs, issues, and goals should also improve the focus and quality of subsequent proposals. It may also be helpful to expand the mentoring program to include all projects in all stages of development to ensure that the PIs' understandings of the industry's perspectives on the issues remain current and the work remains targeted towards the appropriate problems. This may require different mentors to provide the appropriate operational or technical experience as projects proceed through the different stages of development, especially with regards to projects involving equipment modification or replacement during the performance of the project.

It is difficult to estimate the impacts of projects that consist of basic/fundamental research or the establishment of enabling technologies. In most cases these projects have a likelihood of producing information and knowledge that will be of value in the future even if one can't predict exactly how that information will ultimately be used. These projects may not have an immediate impact in and of themselves but rather provide information that is necessary to undertake the integrated, larger impact projects that the industry is targeting. A methodology that demonstrates the value of these projects in terms of accomplishing future/follow-on R\&D in lieu of the immediate impacts projected by the GPRA spreadsheets could be helpful to justify their value and ensure that an adequate amount of basic/fundamental research remains in the pipeline to enable the larger follow-on projects.

It appears as though projects are cyclically selected on a technology group basis with the result that some research proposals were written to emphasize the potential benefits of most 
interest to that particular group. De-emphasizing the technology group and emphasizing larger, integrated projects should encourage proposals that present a more comprehensive picture of potential benefits and take better advantage of potential synergies across technology group lines.

Industry participation at the staff level is on a part-time basis with the attendant difficulties with priorities, availability, and continuity. The level of participation appropriate for industry participants to provide optimum benefit to the program should be determined. As a minimum the program would seem to require a full-time high-level staff person with leadership skills and access to strong analytical capabilities. DOE's continued support for this participation would ensure that a broad industry perspective regarding industry needs as well as sensitivity to national energy and environmental concerns is maintained.

Through discussions with the Steering Group, it is recognized that the forest products industry is taking steps to improve the R\&D process and action is already underway in many instances.

\subsection{Agenda 2020 Implementation Plan and Portfolio}

The Agenda 2020 Implementation Plan was organized into six areas of research and development. The R\&D pathways that represented the initial strategy for the Agenda 2020 Program were subordinated to these six areas in the form of the structure presented in Appendix F. The project work in each of these areas fell under the technological oversight of a specifically assigned Task Group in a one-to-one relationship. Each of these areas was fully represented by the projects that were evaluated in the course of this study. These projects will make significant contributions to the Agenda 2020 program in their respective areas of technology. Furthermore, the potential contributions to be made by many of the projects that were studied appear to have value in one or more of the other areas of R\&D as well. Specific observations regarding the relationship of the projects evaluated to the Agenda 2020 Implementation Plan (on an area-by-area basis) are as follows.

\section{Sustainable Forestry}

All the Sustainable Forestry research projects that were evaluated can, in some respect, be classified as nutrient allocation or genetic research oriented towards lumber and fiber production and there appears to be some overlap in the various research projects. These projects are well aligned with three of the four R\&D pathways envisioned in the Agenda 2020 Implementation Plan. The fourth pathway, "Remote Sensing Technologies to Improve Forest Inventory and Stand Management" is somewhat represented by projects in the Sensors and Controls technology group. Because of the fundamental nature of these research projects, the realization of benefits will in many cases occur beyond the implementation goal of year 2020 .

It was noted that there are no R\&D pathways in the Agenda 2020 Implementation Plan, nor are there any projects, that specifically target the potential for growing wood as a renewable source of energy although much of the current research could be applied to enhance wood as a renewable energy source. To a degree this situation reflects the historical product lines such as pulp, paper, panels, lumber, etc. that have driven the economics of the forest products industry. It also reflects historically cheap petroleum and natural gas energy supplies. In consideration of an increasing need to reduce dependence on imports of oil and natural gas, genetic research that provides the potential for converting underutilized and 


\section{FOREST PRODUCTS INDUSTRY OF THE FUTURE \\ PORTFOLIO STUDY AND EVALUATION}

less fertile land to grow trees to produce a renewable supply of energy appears to be consistent with DOE objectives. Also, the use of wood as a source of chemicals that displace petroleum products as their feedstock could result in additional fossil fuel savings. DOE sponsors other projects and programs through the Office of Power Technologies (OPT) and the Office of Transportation Technologies (OTT) that are of a similar or related nature but outside of the scope of this study. These other efforts often involve the same industry participants as those in the Agenda 2020 program. Additional projects that build upon the genetics and soil productivity research already underway but with a focus on energy production should be coordinated for maximum overall benefit.

\section{Environmental Performance}

Air emissions and the bleach process were the two common threads throughout most of the projects in the Environmental Performance group. Other projects in the group dealt with reduction and treatment of liquid effluents and an alternative use of solid waste.

A comparative review of the three Environmental Performance R\&D pathways and the nine related Focus Areas against the projects evaluated in this study indicates that the projects address at least eight of the nine Focus Areas listed in the Agenda 2020 Implementation Plan. The exception is the focus area of "Human and Environmental Effects" under the "Improved Margins of Environmental Safety" pathway. There were no projects in this group that considered the human impact of the environmental issues. ${ }^{14}$

\section{Energy Performance}

Three of the seven research projects reviewed in the Energy Performance group were gasification related. Two projects dealt with water removal/drying and the remaining two dealt with combustion processes. These seven projects dealt with four of the six Focus Areas on the Energy Performance R\&D pathways in at least some aspect.

The two Focus Areas that the projects evaluated in this study did not address were "Technologies for Maximizing the Value of Waste Materials and Biomass as an Energy Source" and "Effective Partnerships with Energy Providers in Achieving Renewable Energy Goals". Of particular note when comparing the Continuing Research bullets with the projects that were evaluated was the absence of projects in the areas of turbine research (2 bullets) and wood products processes (3 bullets). Research into turbines (or other devices) that will use gas from gasifiers is critical to the overall system on which the projections of significant energy displacement in the out years are based. ${ }^{15}$

\section{Capital Effectiveness}

The Capital Effectiveness group of projects evaluated in this study addressed the issues and needs of the System and Process Technologies" R\&D pathway. A common approach among the projects in this group was to achieve capital effectiveness through economies of scale. The other two R\&D pathways, "System Fabrication and Construction" and "Systems Efficiency" were well described in the Agenda 2020 Implementation Plan but were not addressed by any of the projects evaluated.

\footnotetext{
${ }^{14}$ The Forest Products Industry has not been successful in pursuing collaborative efforts with the EPA.

${ }^{15}$ DOE's OPT is supporting research in this area.
} 


\section{Recycling}

The Recycling group of projects aligns fairly well with the Agenda 2020 Implementation Plan and addresses four of the five R\&D pathways in this technology area. These projects are moving forward to implementation rapidly and therefore should make good contributions to meeting the Agenda 2020 objectives. The R\&D pathway "Sorting and Collection/Methodologies and Tools" was not addressed by any of the projects that were evaluated.

\section{Sensors and Controls}

The Sensors and Controls group of projects also aligns well with the Agenda 2020 Implementation Plan and addresses three of the five R\&D pathways in this technology area to a reasonable degree. The R\&D pathways "Data Presentation, Interpretation and Human Interface" and "Control System Effectiveness" were not addressed by any of the projects that were evaluated.

\subsection{Proposed New Technology Strategy}

The New Technology Strategy has been under development for some time and is currently in a proposed status. The new strategy is intended to enhance the effectiveness of the Agenda 2020 program based on the experience gained to date. This strategy was the topic of a number of presentations at the Forest, Wood \& Paper Industry Technology Summit in Atlanta, GA in May 2001. A book is currently being drafted and assembled that will document the presentations and deliberations upon which the proposed New Technology Strategy is based. ${ }^{16}$ The new strategy is organized along the lines of eight technology strategy platforms. The original Task Groups' projects are proposed to be aligned under six of these platforms. The proposed New Technology Strategy introduces two new strategy platforms (New Forest-Based Materials and Technologically Advanced Workforce). None of the projects that were evaluated in the course of this study would appear to relate to these two platforms.

The R\&D pathways were reworked to some extent and subordinated to the eight technology platforms in the form of the revised structure presented in Appendix $G$. A review of this structure shows a clearer articulation of the vision for Agenda 2020 and the pathways to achieve that vision. The identification of gaps in knowledge and technology will provide a useful tool for soliciting and analyzing the value of future R\&D projects. The incorporation of specific goals into the structure should provide a useful tool for measuring the performance of future projects in terms of their contributions to the whole of the agenda.

As with the Agenda 2020 Implementation Plan, the potential contributions to be made by many of the projects that were studied appear to have value in one or more of the proposed New Technology Strategy platforms. Specific observations regarding the relationship of these projects to the proposed New Technology Strategy (on a platform-by-platform basis) are as follows.

\footnotetext{
${ }^{16}$ Forest, Wood \& Paper Industry Technology Summit Book (Draft)
} 


\title{
FOREST PRODUCTS INDUSTRY OF THE FUTURE PORTFOLIO STUDY AND EVALUATION
}

\author{
Higher Value Raw Material Supply
}

The Sustainable Forestry group of projects that were evaluated in this study appears to fit well under the goals and objectives of the Higher Value Raw Material Supply platform for the proposed New Technology Strategy. Much of the fundamental genetic research is already targeted at producing a higher valued raw material supply. Genetic engineering of trees for improved strength properties or enhanced pulping characteristics will clearly result in higher value raw materials. Genetic engineering also offers the potential to contribute to the success of other platforms such as Significantly Reduced Manufacturing Costs as well. Research in the area of soils productivity also has the potential to enhance raw material values.

\section{Significantly Reduced Manufacturing Costs}

The proposed New Technology Strategy transforms the former "Capital Effectiveness" task group into the "Breakthrough Technologies" group under the "Significantly Reduced Manufacturing Costs" platform. Doing so seems to give this group of projects a clearer focus and bring it more in line with the description of the R\&D pathways reflected in the Agenda 2020 Implementation Plan details.

The alignment of the Recycling task group projects under the Significantly Reduced Manufacturing Costs platform for the proposed New Technology Strategy appears to be a simple structural shift that also improves the focus of projects within this group. The Recycling group of projects that were evaluated appears to fit well under the goals and objectives that were expressed for this platform of the proposed New Technology Strategy.

The alignment of the Sensors and Controls task group projects under the Significantly Reduced Manufacturing Costs platform for the proposed New Technology Strategy also appears to be a simple structural shift that improves the focus of projects within this group. The Sensors and Controls group of projects also appears to fit well under the goals and objectives that were expressed for this platform of the proposed New Technology Strategy. However, these projects do not address areas such as decision-making tools, process visibility sensors, and control system techniques as identified in the Technology Summit.

\section{Improved Energy Performance}

There is strong continuity from the Energy Performance technology group in the Agenda 2020 Implementation Plan to the Improved Energy Performance platform of the proposed New Technology Strategy in the area of biomass and black liquor gasification and defined targets against which progress may be gauged. The Energy Performance group of projects fits well with the new strategy in the gasification Area of Focus. However, these projects do not address the other Area of Focus identified as, "Reduce Energy Intensity of Manufacture and Use of Forest Products", and "Extend Life of Durable Goods".

\section{Superior Environmental Performance}

There is also strong continuity from the Environmental Performance technology group in the Agenda 2020 Implementation Plan to the Superior Environmental Performance platform of the proposed New Technology Strategy. The Environmental Performance group of projects aligns well with the restated technology platform. The refinements in the proposed New 
FOREST PRODUCTS INDUSTRY OF THE FUTURE

PORTFOLIO STUDY AND EVALUATION

Technology Strategy serve to make the goals measurable and enhance investigator understanding of the overall industry goals.

\section{New Forest-Based Materials}

None of the projects evaluated in the course of this study would appear to be related to this platform.

Technologically Advanced Workforce

None of the projects evaluated in the course of this study would appear to be related to this platform.

3.9. Comparison of Agenda 2020 Implementation Plan to the Proposed New Technology Strategy

The Agenda 2020 Implementation Plan embodied the original R\&D strategy and served as a point of departure for initiating the R\&D program. Since the inception of the program a greater understanding of the roles played by the government and the forest products industry has developed. In addition, the unique needs for leading and managing collaborative research efforts involving numerous participants in forest products industry has evolved. The proposed New Technology Strategy has grown out of this experience. The forest products industry has taken the lead in redefining, reorganizing, and updating the original R\&D strategy along the lines of eight proposed technology platforms which are intended to produce integrated projects with larger impacts for more substantial industry improvements. The six original task groups' projects have been realigned under six of the eight proposed new technology strategy platforms.

Figure 3-3 presents a comparison based on the projects that were evaluated in this study. Three of the original task groups' projects remain in a one-to-one correspondence with three of the platforms in the proposed New Technology Strategy. The remaining three task groups' projects are aligned under the Significantly Reduced Manufacturing Costs platform. Two of the platforms are not represented by projects that were evaluated in this study. 


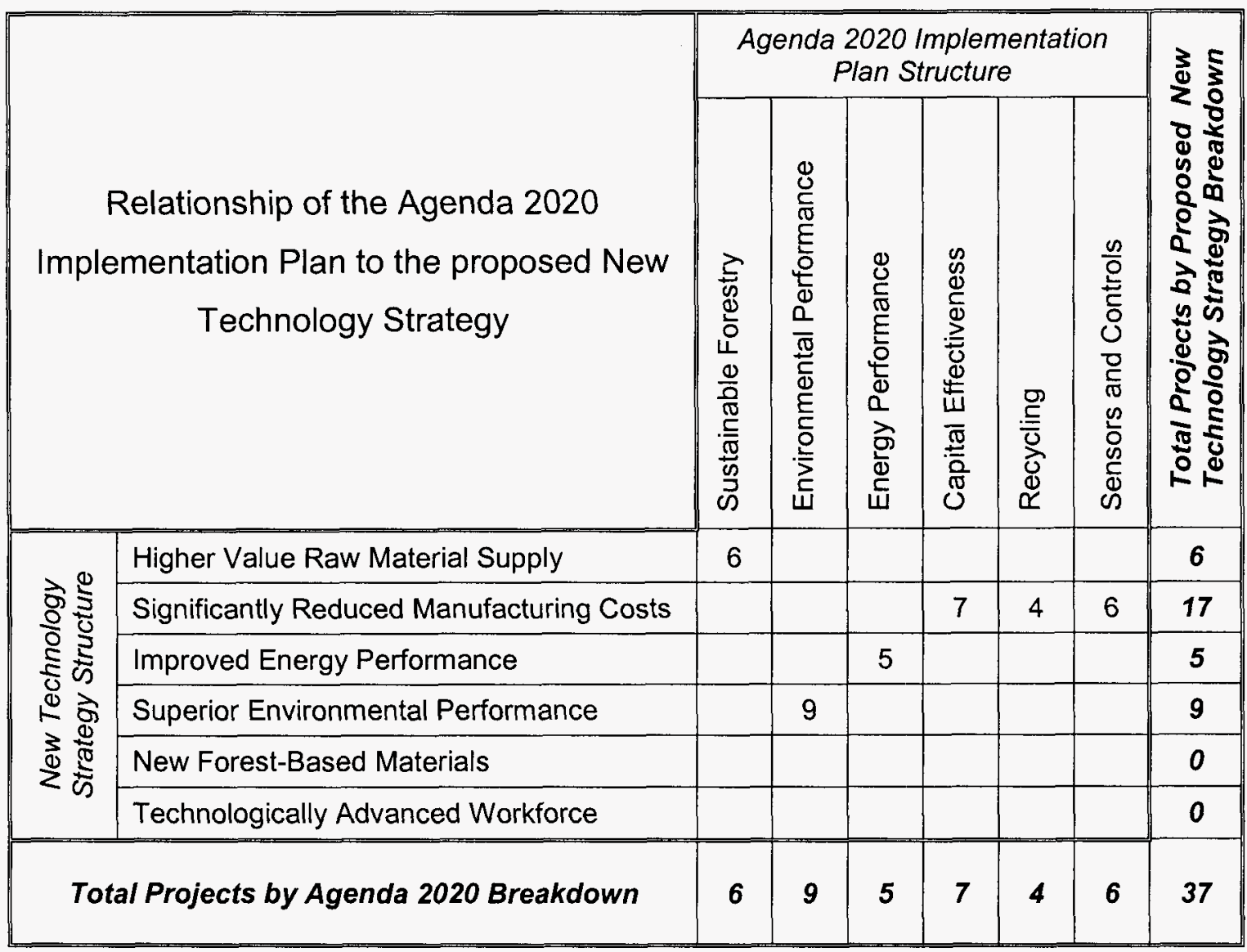

Figure 3-3

Agenda 2020 Implementation Plan vs. the Proposed New Technology Strategy

\subsection{Impact Assessment Methodology}

The methodology used to generate projections of project impacts is embodied in the GPRA spreadsheet. The calculations performed by the spreadsheet depend upon the initial inputs provided by the PIs and proposers and on the assumptions used for estimating and projecting the impacts. These projections can be improved by annually updating the inputs based on the project work and knowledge gained. Consistent transcription of the assumptions contained in the proposals to the spreadsheets would provide readily available information to facilitate an understanding of the impact projections without having to resort to additional documents.

The GPRA spreadsheets were designed to compare the impact of new equipment or process changes. However research and development projects by themselves do not produce widespread process changes or equipment installations. Therefore, when the GPRA spreadsheets calculate projections of impacts of R\&D projects there is an implied assumption that the R\&D will result in equipment or process changes. Because research and development projects may not be successful or several projects may be targeting the same benefit there is the possibility for overestimating or duplicating potential energy savings estimates. OIT recognizes this possibility in their approach and reduces the projected energy savings to $20 \%$ of that projected to compensate for the fact not all projects will be successful. However, the savings are not modified to take into account the 


\section{FOREST PRODUCTS INDUSTRY OF THE FUTURE PORTFOLIO STUDY AND EVALUATION}

duplication of the potential savings by projects addressing the same problem. Since there are no mitigating provisions for estimating high, low, and most likely numbers for the various parameters in the spreadsheet, there is insufficient data to enable a statistical evaluation of the data. Incorporation of statistical methods may improve the process for estimating these impacts.

The GPRA spreadsheets are used to collect and process technology impact information consisting of estimates of energy performance, environmental performance, cost performance, and market penetration. It appears as though the GPRA spreadsheets generated at the beginning of the project as part of an initial justification process are not updated annually or at the end of the project to reflect the knowledge gained from performing the project. As a consequence, the GPRA spreadsheets do not appear to contribute as much to the R\&D process as they might.

In order to assess the impact of the proposed technology, the proposer must provide specific comparisons with the best available technology for each of the energy performance, environmental performance, and cost parameters. There are no independent means for selecting or confirming the best available technology and determining the appropriate performance parameter values to be used for the comparison.

The Agenda 2020 projects vary in their stages of development from fundamental, basic research to full-scale demonstration. Very reliable estimates of performance, cost, and market penetration factors can be made for full-scale demonstration projects where the process and equipment design are well defined and quantity-based estimates can be generated. At the other end of the spectrum, however, estimates of these same parameters for fundamental research projects are highly speculative. Furthermore, the fundamental knowledge gained from fundamental research may have applications that the researcher never considered and, conversely, that same knowledge may determine limitations, or even disprove the viability of applications that were initially anticipated.

There are also instances where several projects, even at the demonstration level, are also parts of a greater whole. An example of this would be the gasification and combined cycle projects. The potential exists to report technology impact values that would be expected for an integrated gasification combined cycle project as inputs for each gasification and gasification combined cycle project with a resultant multiplication and overestimation of benefits.

Although there are some limitations and shortcomings in the current methodology for impact assessments, the methodology demands the necessary discipline of requiring the submittal of data appropriate to the measurement of a project's value. It also requires consistency in treating these data once they are in the system. The comparisons made between projects are dependable to the extent that the input data is reliable and accurate. The methodology also uses of data tables for such factors as combustion emission rates for various fuels, industrial energy prices, energy content of fuels, and projected fossil fuel generation mixes. The use of these tables in the spreadsheet calculations ensures that the data reported by proposers is given a consistent treatment from that point forward. Furthermore, the table can be updated on an annual basis or upon any occasions where large changes are experienced in the national economy. This facility enables normalization of impacts for comparisons of projects that occur in different years and the adjustment of impact projections for varying economic conditions. 


\section{FOREST PRODUCTS INDUSTRY OF THE FUTURE PORTFOLIO STUDY AND EVALUATION}

\subsection{Bubble Charts}

In order to present the relationships between the project evaluation data, stage of development data, energy savings data, and project costs, two series of graphs were generated. A bubble chart format was used wherein the size of each bubble on the charts was proportional to the project cost for the project that it represented. Each series consists of seven bubble charts, one that presents data for all thirty-seven projects, and one for each of the six technology groups.

The first series of bubble charts plots the projected energy savings (in trillions of BTUs in the year 2030) versus weighted ratings for each of the projects evaluated. Because the projected energy benefits vary widely in magnitude, a log scale was used in order to make these figures presentable. The charts showing these data for all of the projects and for the Energy Performance group of projects used an upper limit of 10,000 trillion BTUs for this scale because of the magnitude of the projected energy savings attributable to this technology group. The chart for the other technology groups (with the exception of the Sustainable Forestry group) used an upper limit of 1,000 trillion BTUs on this scale to obtain the best presentation of data. The Sustainable Forestry group of projects had projections of comparatively small energy savings, all of which were less than 6 trillion BTUs.

Consequently, a linear scale with an upper limit of 6 trillion BTUs was used for this particular chart. A linear scale was used for the weighted ratings with an upper limit of 400 , which is the maximum weighted rating possible within the Project Evaluation System.

The second series plots the stages of development versus the weighted ratings for each of the projects evaluated. A linear scale with an upper limit of 6 was used for the Stages of Development and the linear scale with an upper limit of 400 was used for the weighted ratings. These scales were used for all seven charts in this series.

\section{All Projects - Energy Savings}

Figure 3-4 presents the projected energy savings for all of the projects evaluated during the course of this study. A different color was used to distinguish data associated with each of the six technology groups. The All Projects chart is unique from the energy perspective in that all of the projects can be compared using the same energy scale. 


\section{All Projects - Research Budget vs Energy Savings vs Weighted Rating}

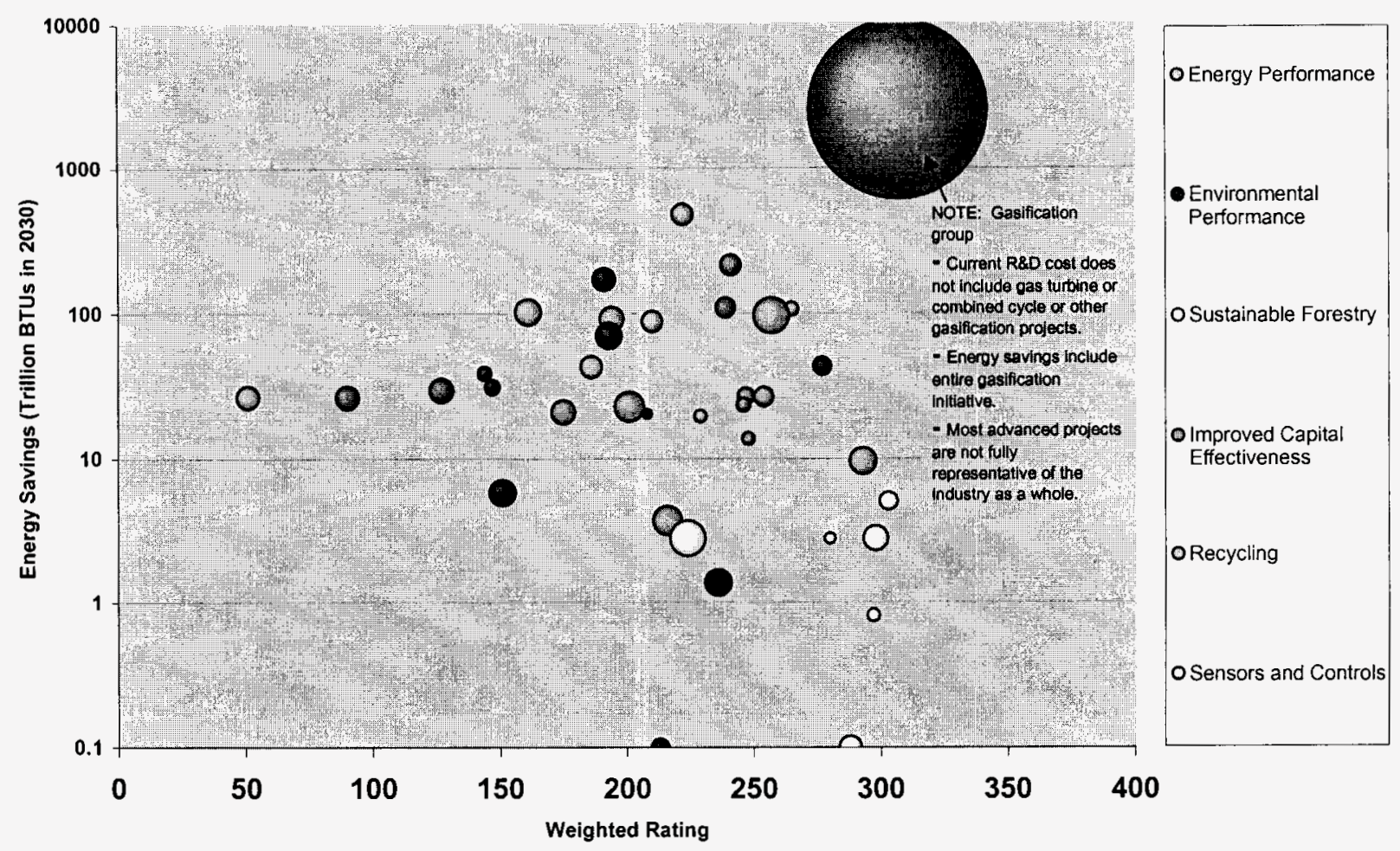

Figure 3-4

One way to interpret these data is to begin by dividing the chart into quadrants. As discussed earlier, a weighted rating of 150 or more indicates a highly rated project therefore this value can serve as a useful vertical dividing line. A figure of 10 trillion BTUs in year 2030 for energy savings seems to be sufficiently significant to provide a horizontal dividing line. With the quadrants thus defined, the lower left quadrant would indicate those projects that are expected to produce the least impact and the upper right quadrant would indicate those projects that are expected to produce the greatest impact. Those projects in the upper left and lower right quadrants would both be expected to have a moderate impact with the upper left being more significant from an energy savings perspective and the lower right being more significant from a forest products industry perspective. Using this means, there are no projects $(0 \%)$ in the lower left quadrant, five projects $(13 \%)$ in the upper left quadrant, eleven $(30 \%)$ in the lower right quadrant and twenty-one $(57 \%)$ in the upper right quadrant. Because the Project Evaluation System took industry goals as the basis for defining and weighting its evaluation parameters, it may be concluded that $57 \%$ of the thirty-seven projects evaluated in this study have the potential to make a high impact on meeting the industry goals and the remaining $43 \%$ have the potential to produce a moderate impact. Significantly, there were no projects that lacked the potential to make a noteworthy impact. Even those projects that scored very low weighted ratings were projects that addressed important problems in the industry and their low scores merely indicate that more effective, marketable solutions remain to be found.

Also immediately apparent is the one very large bubble in the upper right of the chart that dominates the picture. This bubble represents the gasification group of projects, which in turn represents the majority of the resources that were committed to the projects that were 


\section{FOREST PRODUCTS INDUSTRY OF THE FUTURE \\ PORTFOLIO STUDY AND EVALUATION}

evaluated. Several considerations regarding the interpretation of this data point are noted on the chart.

$$
\text { Energy Performance Group - Energy Savings }
$$

Figure 3-5 presents the projected energy savings for the five projects in the Energy Performance group of projects. A different color was used to distinguish data associated with each of the projects in this group.

Energy Performance Group Projects

Research Budget vs. Energy Savings vs. Weighted Rating

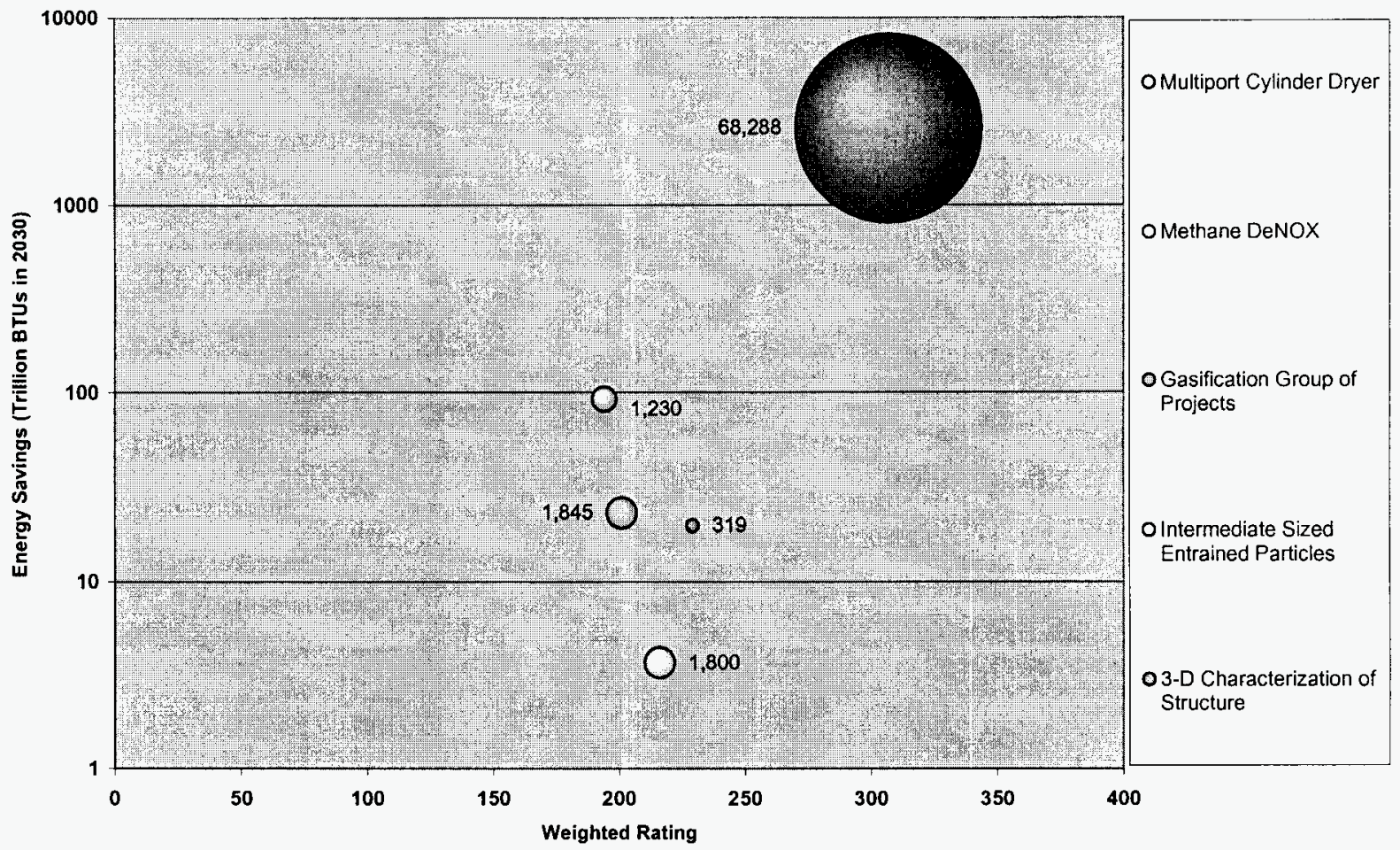

Figure 3-5

Using the quadrant definitions discussed previously, there are no projects $(0 \%)$ in either the lower left or the upper left quadrants, one project $(20 \%)$ in the lower right quadrant, and four $(80 \%)$ in the upper right quadrant. 


\section{FOREST PRODUCTS INDUSTRY OF THE FUTURE PORTFOLIO STUDY AND EVALUATION}

\section{Environmental Performance Group - Energy Savings}

Figure 3-6 presents the projected energy savings for the nine projects in the Environmental Performance group of projects. A different color was used to distinguish data associated with each of the projects in this group.

Environmental Performance Group Projects

Research Budget vs. Energy Savings vs. Weighted Rating

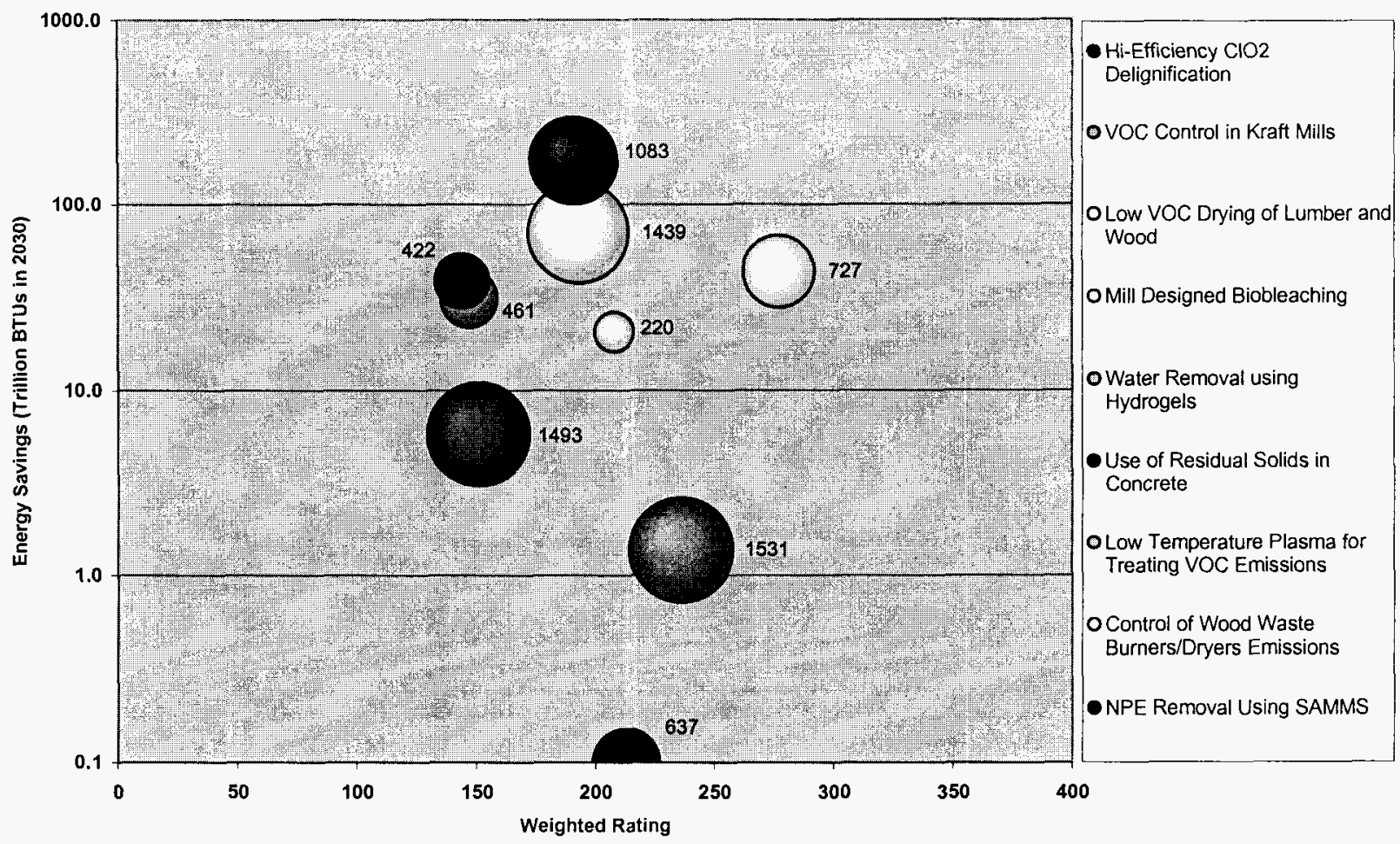

Figure 3-6

Using the quadrant definitions discussed previously, there are no projects $(0 \%)$ in the lower left quadrant, two projects $(22 \%)$ in the upper left quadrant, three $(33 \%)$ in the lower right quadrant, and four ( $45 \%)$ in the upper right quadrant. 


\section{FOREST PRODUCTS INDUSTRY OF THE FUTURE \\ PORTFOLIO STUDY AND EVALUATION}

\section{Sustainable Forestry Group - Energy Savings}

Figure 3-7 presents the projected energy savings for the six projects in the Sustainable Forestry group of projects. A different color was used to distinguish data associated with each of the projects in this group.

Sustainable Forestry Group Projects

Research Budget vs. Energy Savings vs. Weighted Rating

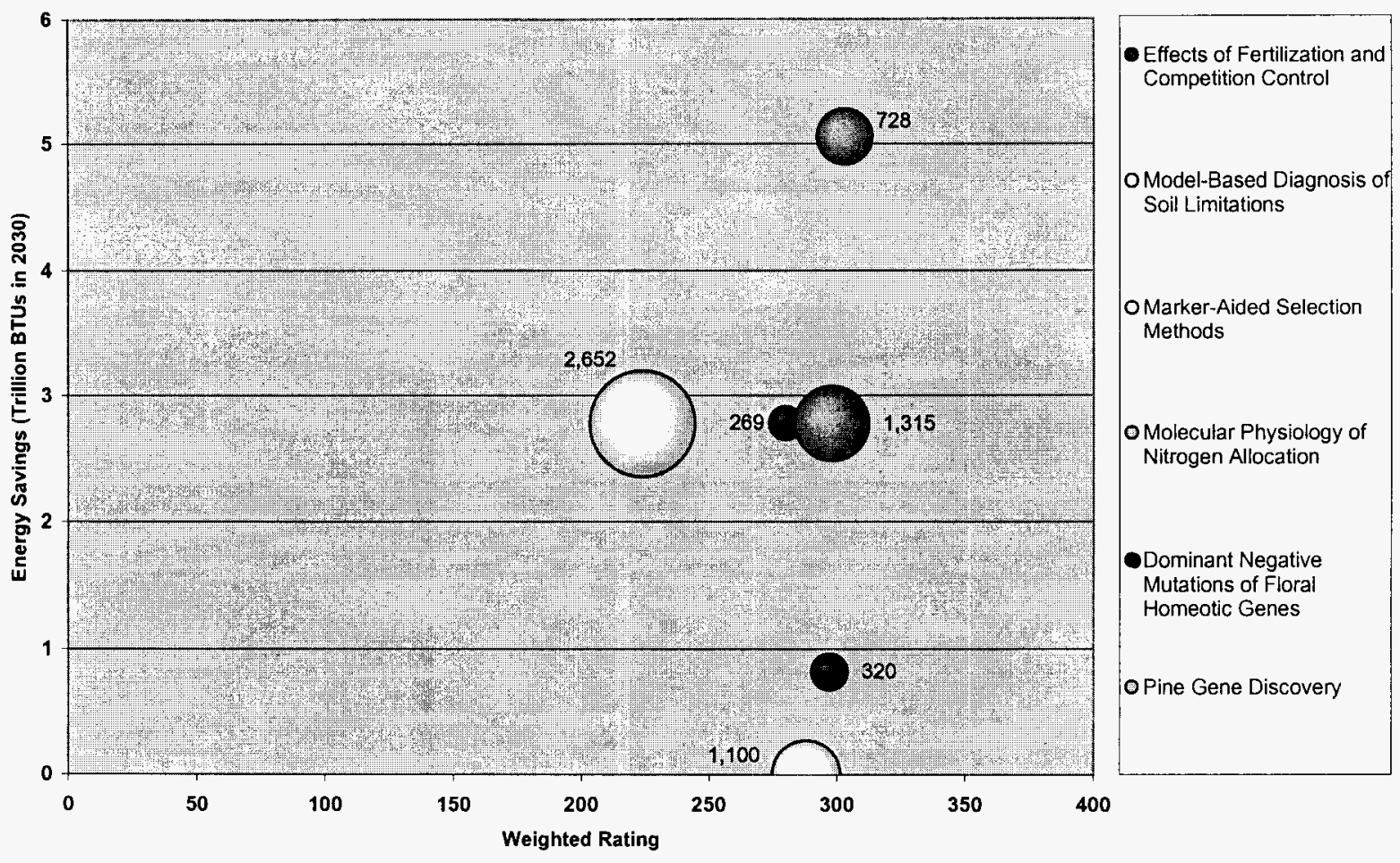

Figure 3-7

Using the quadrant definitions discussed previously, there are no projects $(0 \%)$ in the lower left, upper left and upper right quadrants. All of the projects in this group are in the lower right quadrant. 


\section{FOREST PRODUCTS INDUSTRY OF THE FUTURE \\ PORTFOLIO STUDY AND EVALUATION}

\section{Improved Capital Effectiveness Group - Energy Savings}

Figure 3-8 presents the projected energy savings for the seven projects in the Improved Capital Effectiveness group of projects. A different color was used to distinguish data associated with each of the projects in this group.

\section{Improved Capital Effectiveness Group Projects \\ Research Budget vs. Energy Savings vs. Weighted Rating}

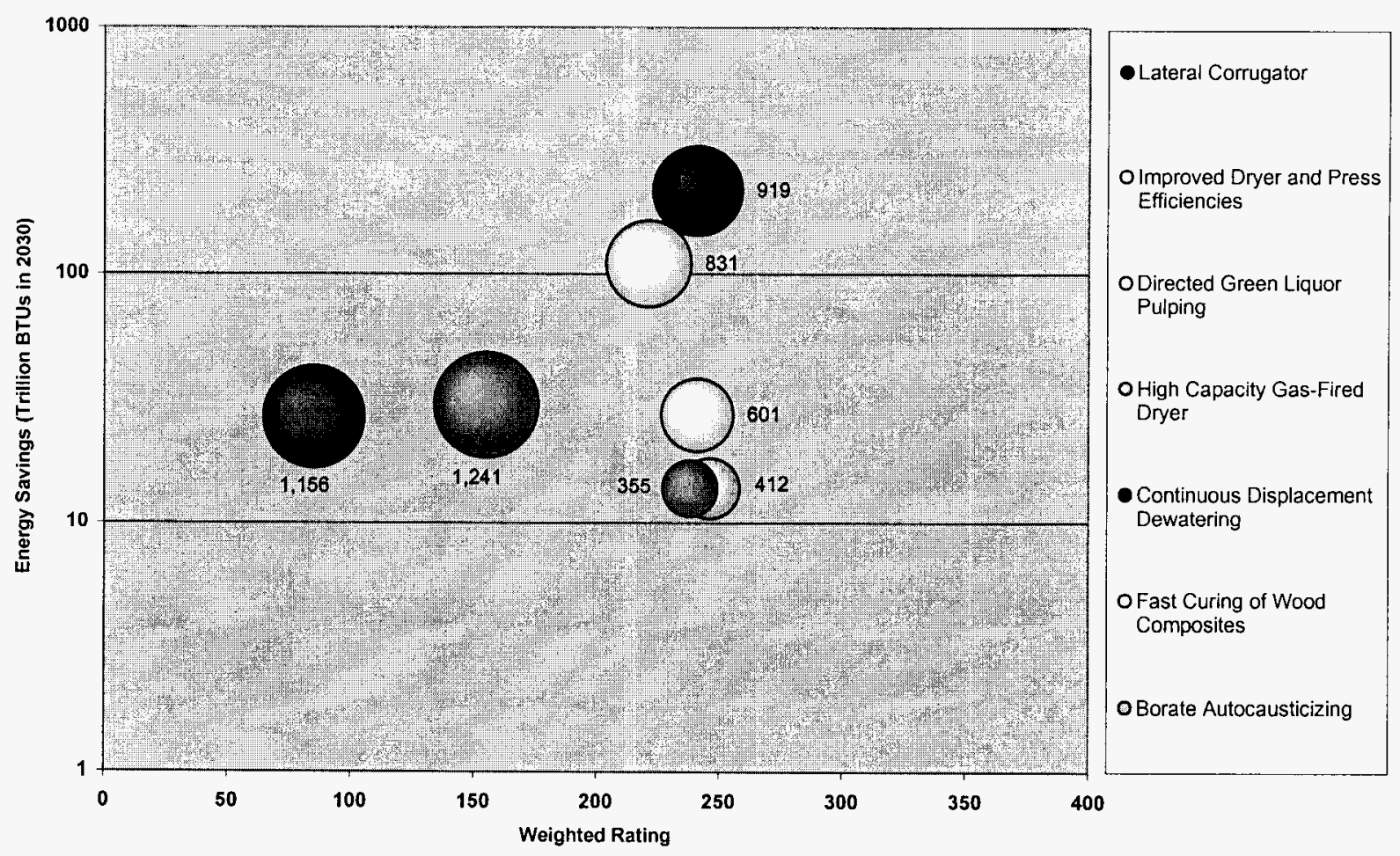

Figure 3-8

Using the quadrant definitions discussed previously, there are no projects $(0 \%)$ in the lower left and lower right quadrants, one project (14\%) in the upper left quadrant, and six (86\%) in the upper right quadrant. 


\section{FOREST PRODUCTS INDUSTRY OF THE FUTURE PORTFOLIO STUDY AND EVALUATION}

\section{Recycling Group - Energy Savings}

Figure 3-9 presents the projected energy savings for the four projects in the Recycling group of projects. A different color was used to distinguish data associated with each of the projects in this group.

Recycling Group Projects

Research Budget vs. Energy Savings vs. Weighted Rating

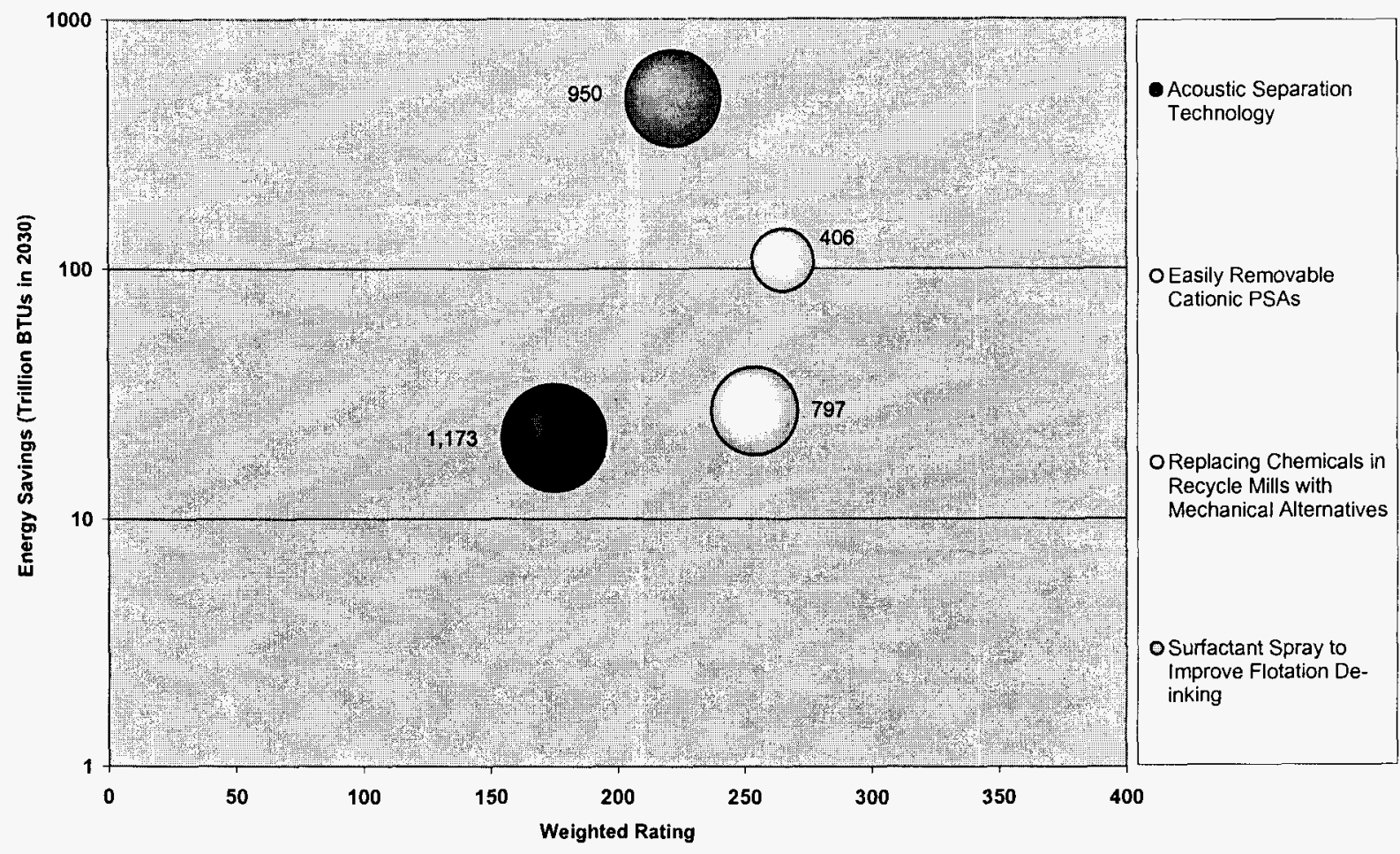

Figure 3-9

Using the quadrant definitions discussed previously, there are no projects ( $0 \%)$ in the lower left, upper left and lower right quadrants. All of the projects in this group are in the upper right quadrant.

The energy savings benefit appears to be significant for each of these Recycling projects. This group of projects includes the second and the fifth highest energy savings and the project with the lowest savings is higher than many of the other projects reviewed. 


\section{FOREST PRODUCTS INDUSTRY OF THE FUTURE \\ PORTFOLIO STUDY AND EVALUATION}

\section{Sensors and Controls Group - Energy Savings}

Figure 3-10 presents the projected energy savings for the six projects in the Sensors and Controls group of projects. A different color was used to distinguish data associated with each of the projects in this group.

Sensors and Controls Group Projects

Research Budget vs. Energy Savings vs. Weighted Rating

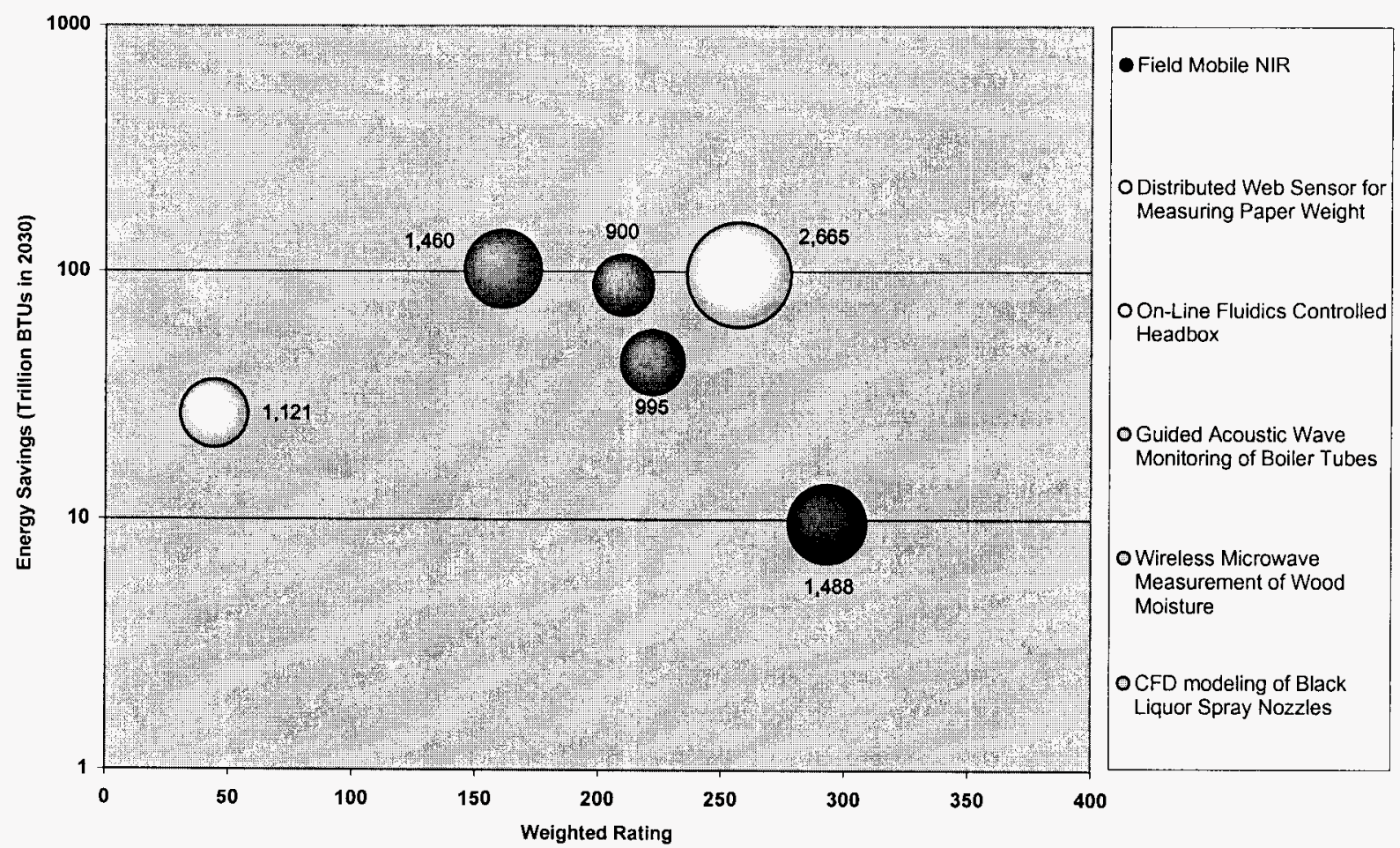

Figure 3-10

Using the quadrant definitions discussed previously, there are no projects $(0 \%)$ in the lower left quadrant, one project $(17 \%)$ in the upper left quadrant, one $(17 \%)$ in the lower right quadrant, and four (66\%) in the upper right quadrant. 


\section{FOREST PRODUCTS INDUSTRY OF THE FUTURE \\ PORTFOLIO STUDY AND EVALUATION}

\section{All Projects - Stages of Development}

Figure 3-11 presents the Stages of Development for all of the projects evaluated during the course of this study. A different color was used to distinguish data associated with each of the six technology groups.

\section{All Projects - Research Budget vs. Weighted Rating vs. Development Stage}

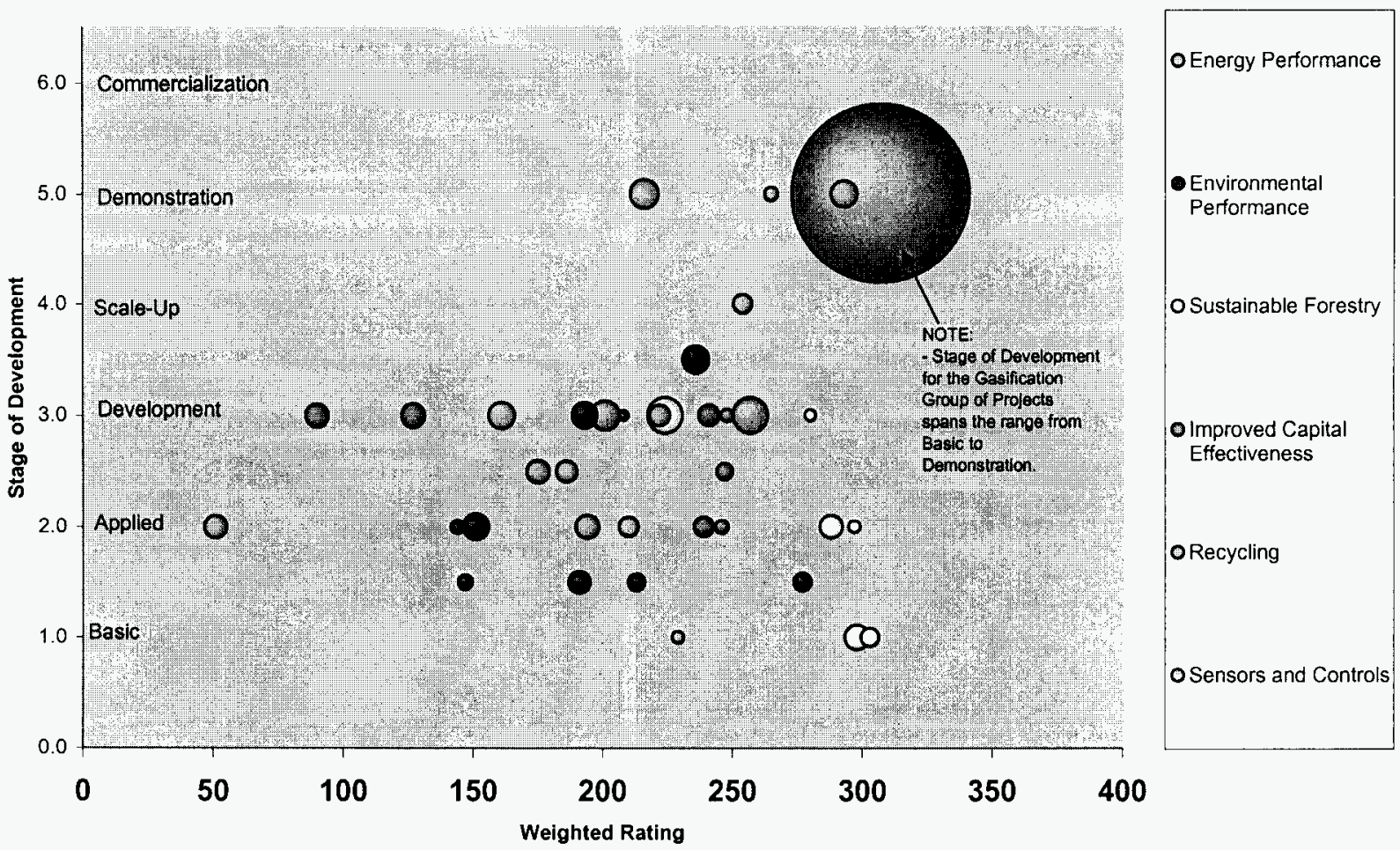

Figure 3-11

A manner similar to that used to interpret the bubble charts that show energy savings data can be adapted to the bubble charts that show Stages of Development data. In this case, however, the ideally balanced portfolio would show a distribution of projects across all of the stages of development. Therefore a horizontal dividing line is not useful and the chart can more effectively be considered in terms of a right and left section with a vertical dividing line between them. As discussed previously, a weighted rating of 150 or more in this study indicates a highly rated project and can be used in a generalized fashion to serve as a point to divide the graph into sections to make common observations. With the sections thus defined, the left section would indicate those projects that are expected to produce the least impact and the right section would indicate those projects that are expected to produce the greatest impact. Using this means, there are five projects $(14 \%)$ in the left section and thirty-two projects $(86 \%)$ in the right section.

The five projects represented in the left section are in the three earliest stages of development. The thirty-two projects in the right section are well distributed amongst the five stages. 


\section{FOREST PRODUCTS INDUSTRY OF THE FUTURE PORTFOLIO STUDY AND EVALUATION}

\section{Energy Performance Group - Stages of Development}

Figure 3-12 presents the Stages of Development for the five projects in the Energy Performance group of projects. A different color was used to distinguish data associated with each of the projects in this group.

Energy Performance Group Projects

Research Budget vs. Stage of Development vs. Weighted Rating

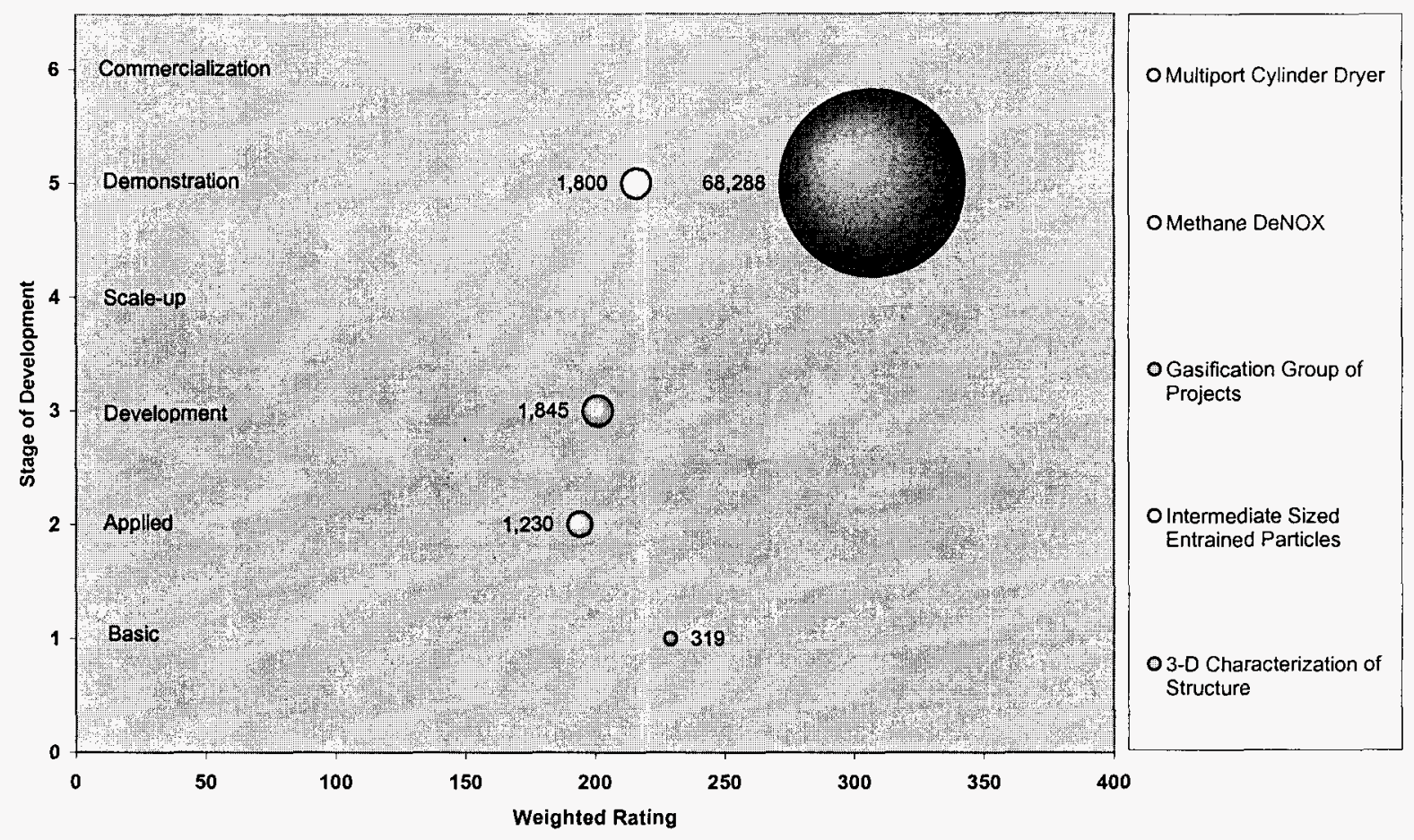

Figure 3-12

Using the section definitions discussed previously, there are no projects $(0 \%)$ in the left section. All five projects $(100 \%)$ are in the right section.

The right section shows an even distribution of projects amongst the five stages of development. 


\section{FOREST PRODUCTS INDUSTRY OF THE FUTURE \\ PORTFOLIO STUDY AND EVALUATION}

\section{Environmental Performance Group - Stages of Development}

Figure 3-13 presents the Stages of Development for the nine projects in the Environmental Performance group of projects. A different color was used to distinguish data associated with each of the projects in this group.

Environmental Performance Group Projects

Research Budget vs. Stage of Development vs. Weighted Rating

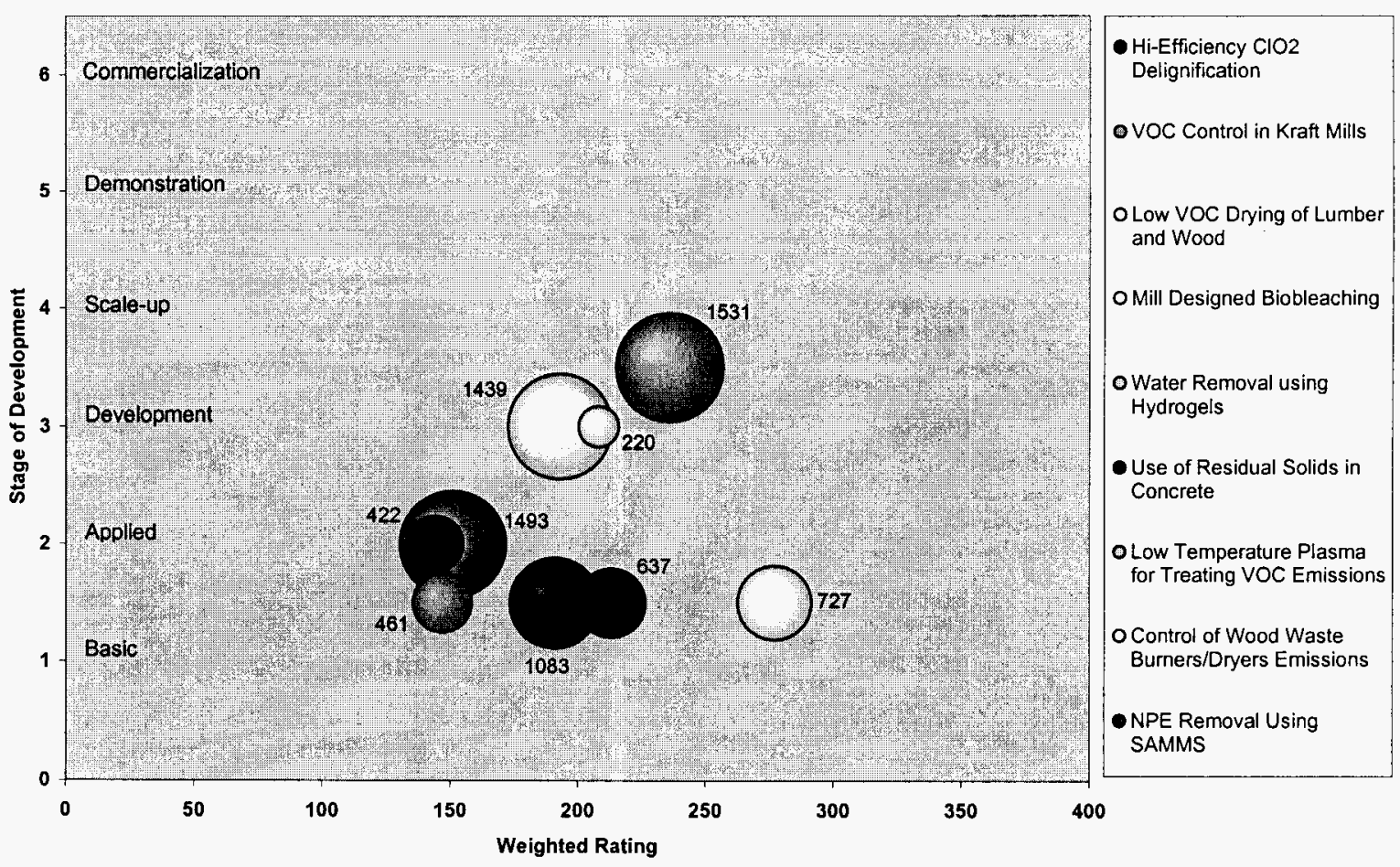

Figure 3-13

Using the section definitions discussed previously, two projects $(22 \%)$ are in the left section and seven projects $(78 \%)$ are in the right.

The two projects represented in the left section are in the two earliest stages of development. The seven projects in the right section are distributed amongst the first four stages, however, there are no projects in the group that have advanced to Stage 5. 


\section{FOREST PRODUCTS INDUSTRY OF THE FUTURE \\ PORTFOLIO STUDY AND EVALUATION}

\section{Sustainable Forestry Group - Stages of Development}

Figure 3-14 presents the Stages of Development for the six projects in the Sustainable Forestry group of projects. A different color was used to distinguish data associated with each of the projects in this group.

Sustainable Forestry Group Projects

Research Budget vs. Stage of Development vs. Weighted Rating

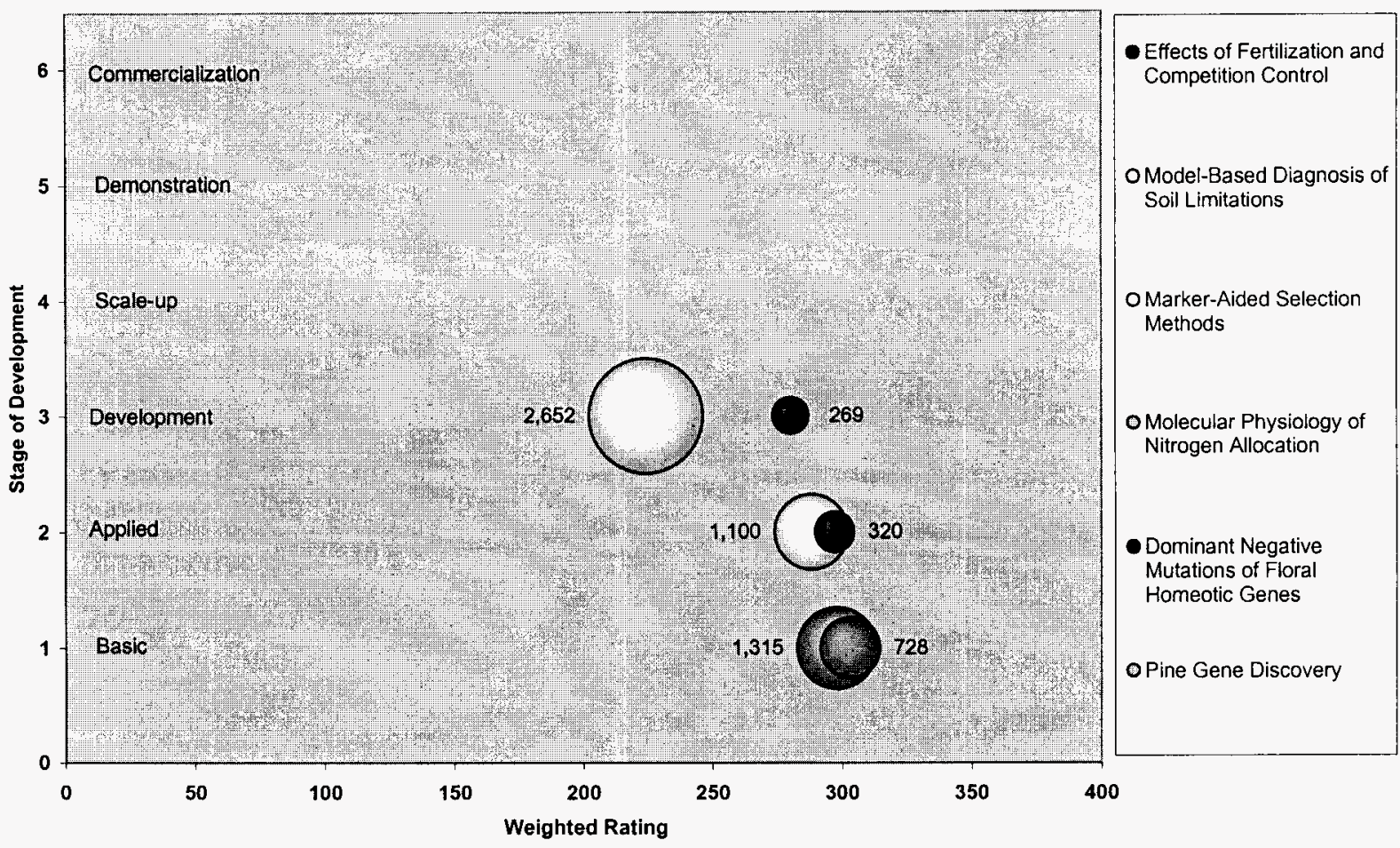

Figure 3-14

Using the section definitions discussed previously, there are no projects $(0 \%)$ in the left section. All six projects $(100 \%)$ are in the right section.

The right section shows an even distribution of projects amongst the first three stages of development. There are no projects in the group that have advanced to Stages 4 and 5 . 


\section{FOREST PRODUCTS INDUSTRY OF THE FUTURE PORTFOLIO STUDY AND EVALUATION}

\section{Improved Capital Effectiveness Group - Stages of Development}

Figure 3-15 presents the Stages of Development for the seven projects in the Improved Capital Effectiveness group of projects. A different color was used to distinguish data associated with each of the projects in this group.

Improved Capital Effectiveness Group Projects

Research Budget vs. Stage of Development vs. Weighted Rating

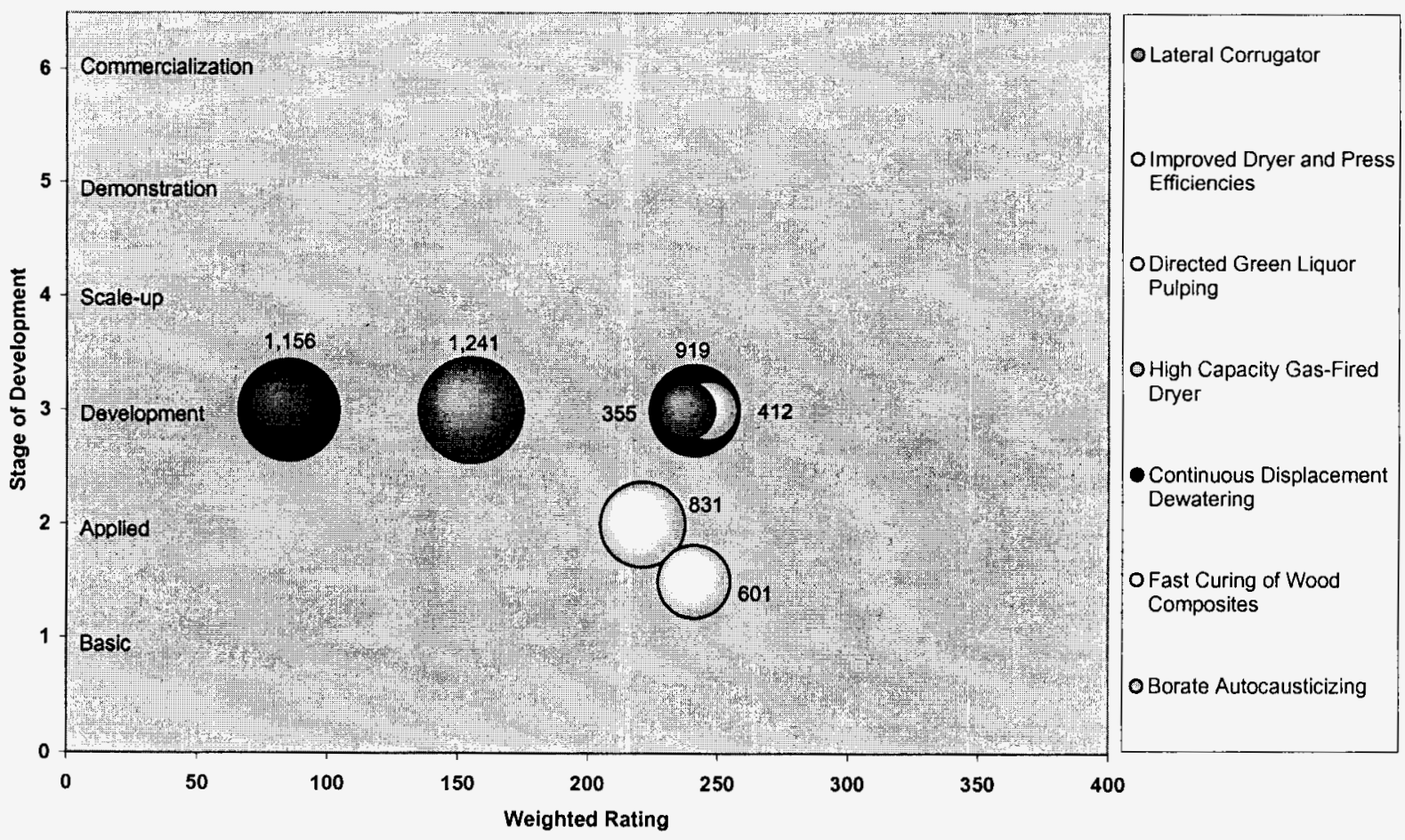

Figure 3-15

Using the section definitions discussed previously, one project (14\%) is in the left section and six projects $(86 \%)$ are in the right.

The only project represented in the left section is in Stage 3. The six projects in the right section are distributed amongst the first three stages; however, there are no projects in this relatively new group that have advanced to Stage 4 or beyond. 


\section{FOREST PRODUCTS INDUSTRY OF THE FUTURE \\ PORTFOLIO STUDY AND EVALUATION}

\section{Recycling Group - Stages of Development}

Figure 3-16 presents the Stages of Development for the four projects in the Recycling group of projects. A different color was used to distinguish data associated with each of the projects in this group.

Recycling Group Projects

Research Budget vs. Stage of Development vs. Weighted Rating

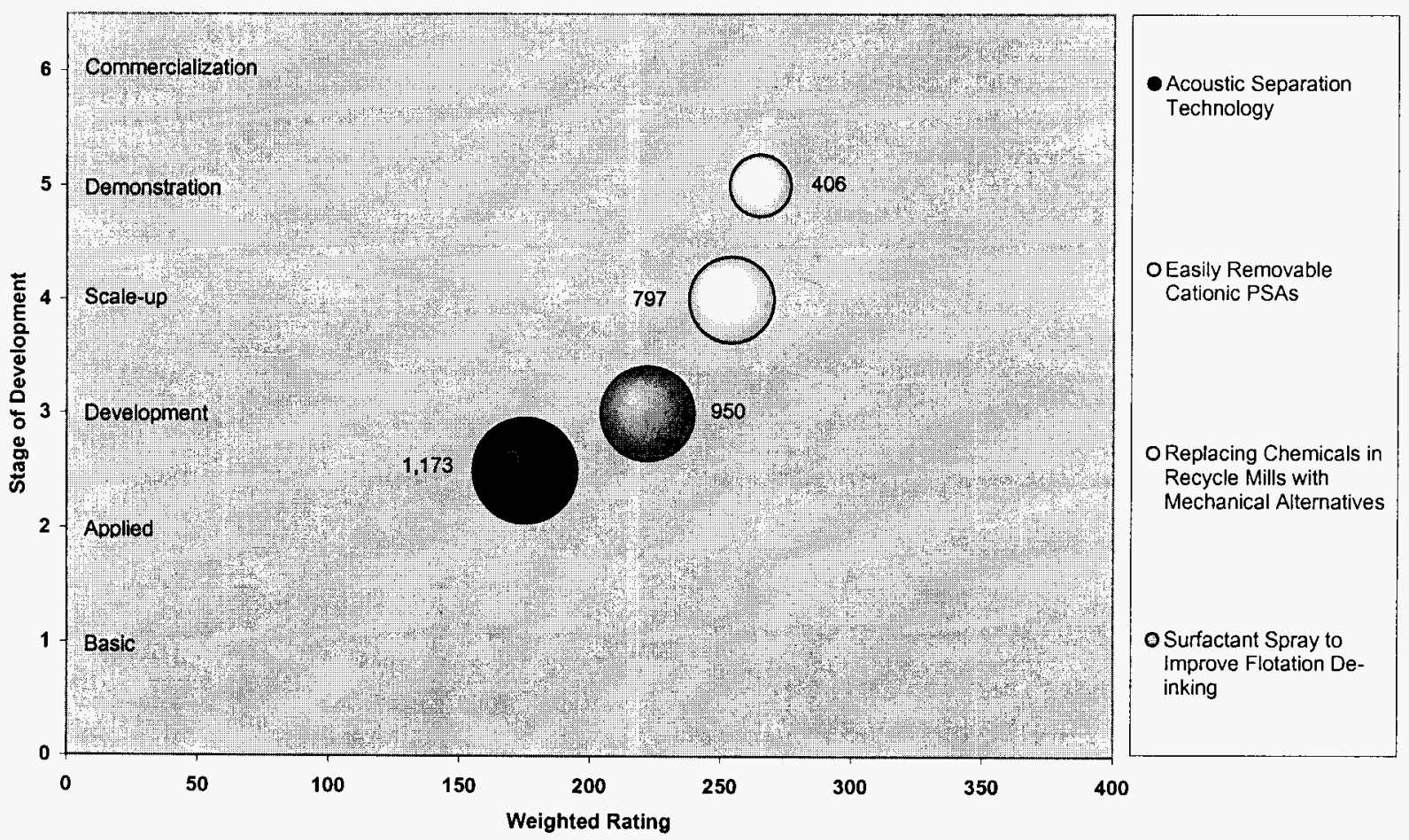

Figure 3-16

Using the section definitions discussed previously, there are no projects $(0 \%)$ in the left section. All four projects (100\%) are in the right.

The right section shows a distribution of projects amongst the final four stages of development. The initial stages of development may not be well represented in this group: however, this may be merely a reflection of the fact that only four projects in this group were evaluated. 


\section{FOREST PRODUCTS INDUSTRY OF THE FUTURE \\ PORTFOLIO STUDY AND EVALUATION}

\section{Sensors and Controls Group - Stages of Development}

Figure 3-17 presents the Stages of Development for the six projects in the Sensors and Controls group of projects. A different color was used to distinguish data associated with each of the projects in this group.

Sensors and Controls Group Projects

Research Budget vs. Stage of Development vs. Weighted Rating

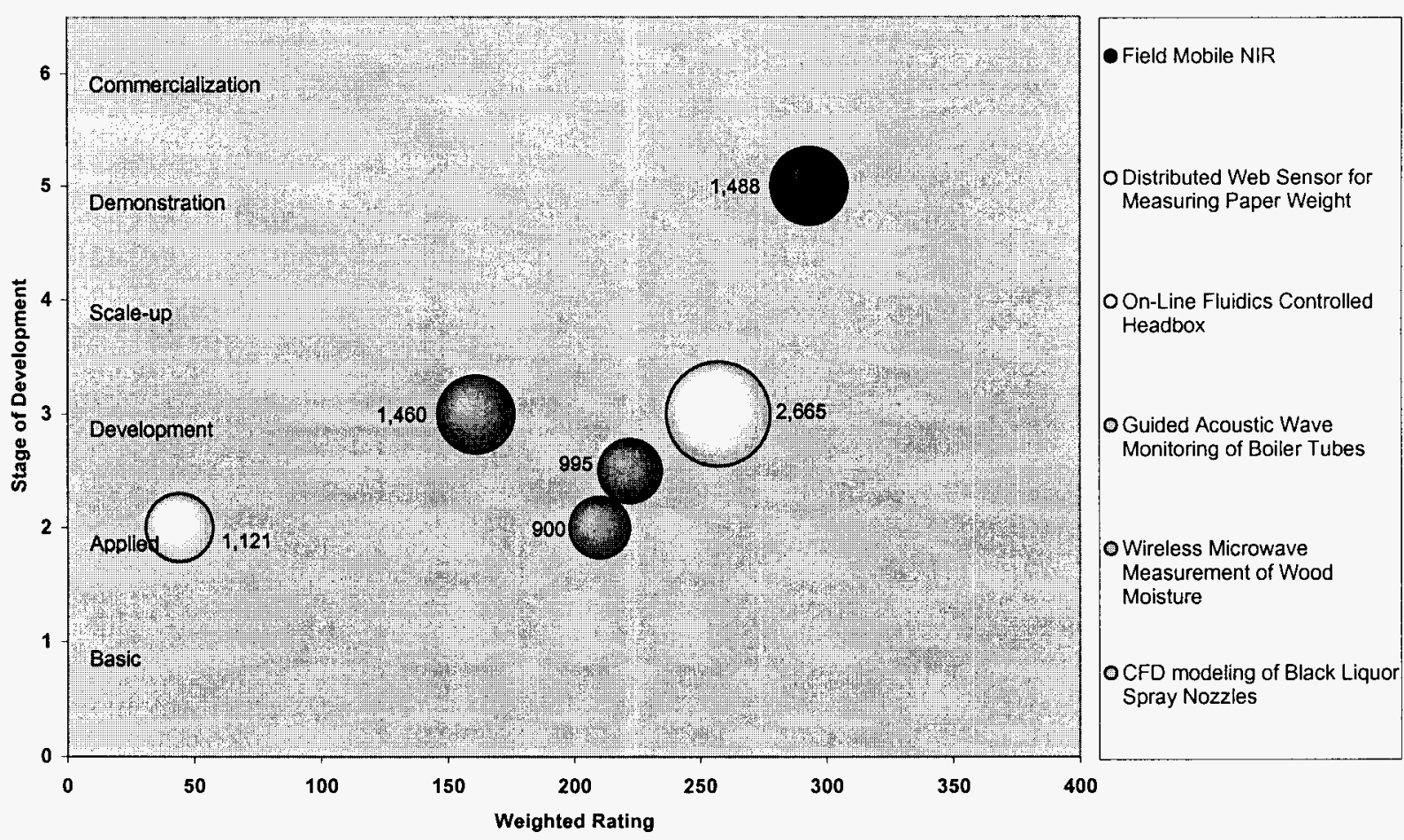

Figure 3-17

Using the section definitions discussed previously, one project $(17 \%)$ is in the left section and five projects $(83 \%)$ are in the right.

The only project represented in the left section is in Stage 2. The six projects in the right section are grouped in the middle stages with one that has progressed to Stage 5 . There are no projects in the group in either Stage 1 or Stage 4. 


\author{
Section 4 \\ Conclusions and Recommendations
}

4.1. Conclusions

\title{
The Agenda 2020 R\&D Program
}

- The Agenda 2020 program shows noteworthy progress in tangible, quantifiable terms and has the potential to produce a substantial positive effect on energy and cost savings for the forest products industry and the nation as a whole.

- There are significant R\&D projects in the portfolio that were made possible by the shared risk aspects of the Agenda 2020 program-the Black Liquor Gasification Project is a good example

- The Agenda 2020 program facilitates the industry's efforts to clarify needs, establish priorities, and focus the technology R\&D effort for the economic health of the industry and the nation.

- The forest products industry has taken the lead in redefining, reorganizing, and updating the original Agenda 2020 R\&D strategy.

- The Agenda 2020 program has stimulated the development of procedures to effectively evaluate the worth and diversity of R\&D projects necessary to maintain a robust program.

- The degree of collaboration that has developed between the industry, the government, and research organizations (including universities and national laboratories) fosters an environment with potential for effective problem solving.

- In addition to Agenda 2020 projects, DOE sponsors projects and complimentary programs through the Office of Power Technologies and the Office of Transportation Technologies.

\section{Portfolio Management}

- The current portfolio represents a potential for major contributions across the full range of Agenda 2020 R\&D goals. The majority of projects evaluated in this study have the potential to produce a high impact.

- Even projects that scored low weighted impact ratings addressed important problems in the industry and their low scores merely indicate that more effective, marketable solutions remain to be found.

- The project reviews performed by task groups are not uniformly structured or consistently reported to the CTO level in a manner that would facilitate portfolio management activities.

- A method that demonstrates the value of basic/fundamental research projects without depending on the metrics projected by the GPRA spreadsheets could be helpful to justify 


\section{FOREST PRODUCTS INDUSTRY OF THE FUTURE \\ PORTFOLIO STUDY AND EVALUATION}

these projects on the basis of their contributions toward enabling and accomplishing future/follow-on R\&D.

- The magnitude and complexity of the Agenda 2020 program would be more effectively managed by a full-time, high-level staff person with leadership skills and access to strong analytical capabilities.

- Future projects will be aligned under the proposed New Technology Strategy with the intent of more effectively advancing projects through their stages of development and encouraging the pursuit of major, integrated projects with larger impacts.

\section{Impact Projections}

- Impact assessments are a complex blend of quantified projections and subjective evaluations that demand a formal impact assessment methodology to treat all aspects with consistency in order to maintain and balance a long-term program.

- The simple accumulation of energy and cost savings tabulated on individual GPRA spreadsheets results in totals that are overstated.

- The cost savings projected in the GPRA spreadsheets are largely a function of the energy savings. Estimates of capital and non-energy variable costs and assumptions regarding payback terms and other pertinent economic factors were not available, which precluded complete evaluations of economic impacts.

- The assumptions and magnitudes of projected energy and cost savings need to be reviewed and periodically updated by the industry for reasonableness and potential overlap with other projects.

\section{Project Performance}

- The progression through the stages of development shown by the projects evaluated in this study suggests significant progress toward the Agenda 2020 goals.

- The valuable contribution of routine industry reviews of projects could be enhanced by structuring these reviews around common measures applicable to the Agenda 2020 program as a whole.

- The intentions of crosscutting efforts at the task group level during solicitation and project reviews do not always filter down to the Pls. 


\section{FOREST PRODUCTS INDUSTRY OF THE FUTURE}

PORTFOLIO STUDY AND EVALUATION

\subsection{Recommendations}

\section{The Agenda 2020 R\&D Program}

- The forest products industry and DOE should continue support for the Agenda 2020 program

- Provide a forum to facilitate the exchange of information, prior to the submittal of proposals, between researchers and the industry to improve the researchers' understanding of needs, issues, and goals for the Agenda 2020 program.

- The forest products industry and DOE should continue to coordinate the support provided through OIT, OPT and OTT for projects that build upon the current genetics and soil productivity research with a focus on high energy production. Incorporate new projects, as appropriate, into the Agenda 2020 portfolio.

\section{Portfolio Management}

- Continue the practice of having experts from the applicable technology groups contributing inputs to the proposal evaluation and project selection process.

- Maintain the focus of future projects on the development of major, breakthrough technologies in preference to projects that seek incremental improvements in efficiencies, economies of scale, etc.

- Incorporate measures into the project evaluation process that capture the full range of projected impact data. Such measures should include the use of a database or set of standardized numbers that represent consensus values provided through a recognized industry source.

- Incorporate recognized value-engineering practices into the proposal evaluation and project selection process. Involve organizations such as TAPPI Engineering and the Construction Industry Institute (CII) to share their best practices for improving effectiveness in capital investment programs.

- Establish a methodology that demonstrates the value of basic/fundamental research projects in terms of enabling future/follow-on R\&D.

- Establish a methodology for defining the optimum portfolio structure.

- Implement a structured, periodic portfolio review process at the CTO level that draws upon the project reviews performed by task groups to determine if the projects in the portfolio continue to address the high priority industry needs and provide the correct mix of projects in the appropriate stages of development for sustainable success.

- Evaluate cost competitiveness of projects/technologies at all stages of development.

- Provide full time industry leadership for the Agenda 2020 program to ensure effective management of the portfolio. 


\section{FOREST PRODUCTS INDUSTRY OF THE FUTURE}

PORTFOLIO STUDY AND EVALUATION

\section{Impact Projections}

- Continue to use a formal impact assessment methodology that incorporates the GPRA spreadsheet projections and a refined project evaluation process similar to that used in this study.

- Incorporate measures to eliminate the accumulation of benefits whenever multiple projects compete for the same energy savings and/or emissions reduction benefits.

- Require estimates of capital and non-energy variable costs, assumptions regarding payback terms and other pertinent economic inputs on the GPRA spreadsheets for those projects in their later stages of development.

- Complete industry reviews of the reasonableness of assumptions and the magnitude of numbers projected in the GPRA spreadsheets.

- Provide PIs/Project Managers with the GPRA spreadsheet data that was used in the evaluations of their proposals and instructions for generating updated inputs and require annual updates of these inputs. Update the documentation of assumptions and methods for generating estimates on the GPRA spreadsheets.

\section{Project Performance}

- Implement a means to measure individual project progress against the Agenda 2020 Implementation Plan that uses tangible measures such as Stages of Development and/or industry goals.

- Apply common measures for evaluating goals and technical approaches on future proposals/projects.

- Expand the mentoring program to include all projects in all stages of development to ensure that the PIs' understandings of the industry's perspectives on the issues are current and the work remains targeted towards the appropriate problems. 


\section{FOREST PRODUCTS INDUSTRY OF THE FUTURE \\ PORTFOLIO STUDY AND EVALUATION}

Acronyms and Abbreviations

\begin{tabular}{|c|c|}
\hline $\mathrm{ABB}$ & Asea Brown Boveri \\
\hline AF\&PA & American Forest and Paper Association \\
\hline ANL & Argonne National Laboratory \\
\hline AOX & Absorbable Organic Halides \\
\hline $\mathrm{BC}$ & Boise Cascade \\
\hline BTU & British Thermal Unit(s) \\
\hline CFD & Computational Fluid Dynamics \\
\hline $\mathrm{Cll}$ & Construction Industry Institute \\
\hline $\mathrm{ClO}_{2}$ & Chlorine Dioxide \\
\hline $\mathrm{CO}$ & Carbon Monoxide \\
\hline $\mathrm{CO}_{2}$ & Carbon Dioxide \\
\hline COD & Chemical Oxygen Demand \\
\hline CTO & Chief Technology Officer \\
\hline CTOC & Chief Technology Officers Committee \\
\hline $\mathrm{D}_{0}$ & One of a number of stages in the bleaching process \\
\hline DOE & U.S. Department of Energy \\
\hline EERE & Office of Energy Efficiency and Renewable Energy \\
\hline EIA & Energy Information Administration \\
\hline EPA & Environmental Protection Agency \\
\hline FPS & Forest Products Society \\
\hline G-P & Georgia-Pacific \\
\hline GPRA & Government Performance and Results Act \\
\hline HAP & Hazardous Air Pollutant(s) \\
\hline IGCC & Integrated Gasification Combined Cycle \\
\hline INEEL & Idaho National Energy and Environmental Laboratory \\
\hline IP & International Paper \\
\hline IPST & Institute of Paper Science Technology \\
\hline LLN L & Lawrence Livermore National Laboratory \\
\hline LP & Louisiana Pacific \\
\hline MDF & Medium Density Fiberboard \\
\hline MOE & Modulus of Elasticity \\
\hline MOR & Modulus of Rupture \\
\hline
\end{tabular}


PORTFOLIO STUDY AND EVALUATION

NCASI National Council for Air and Stream Improvement

NCG Non-Condensable Gasses

NCSU North Carolina State University

NIR Near-Infrared

$\mathrm{NO}_{\mathrm{x}} \quad$ Nitrogen Oxides

NPE Non-Process Elements

NREL National Renewable Energy Laboratory

NSF National Science Foundation

OCC Old Corrugated Containers

OIT Office of Industrial Technologies

OITIS Office of Industrial Technologies Information System

OPT Office of Power Technologies

ORNL Oak Ridge National Laboratory

OSB Oriented Strand Board

OSU Oregon State University

OTT Office of Transportation Technologies

PI Principal Investigator

PNNL Pacific Northwest National Laboratory

PSA Pressure Sensitive Adhesive(s)

R\&D Research and Development

RFP Request for Proposals

RPTA Recycled Paperboard Technical Association

RTO Regenerative Thermal Oxidizer(s)

SAMMS Self-Assembled Monolayers on Mesoporous Supports

SOW Statement of Work

TAPPI Technical Association of the Pulp and Paper Industry, Inc.

TSS Total Suspended Solids

UGA University of Georgia

USFS U.S. Forest Service

VOC Volatile Organic Compound(s)

VPI Virginia Polytechnic Institute

VTT Technical Research Center of Finland (Valtion Teknillinen Tutkinuskeskus)

WSU Washington State University 


\section{FOREST PRODUCTS INDUSTRY OF THE FUTURE PORTFOLIO STUDY AND EVALUATION}

\section{References}

1. American Forest \& Paper Association. Agenda 2020: A Technology Vision and Research Agenda for America's Forest, Wood and Paper Industry. November 1994.

2. American Forest \& Paper Association. Agenda 2020: The Path Forward - An Implementation Plan.

3. Bordley, Robert F. "R\&D Project Selection vs. R\&D Project Generation." A paper prepared by the Manager of General Motor's R\&D Portfolio Planning Department.

4. E.D. Larson, T.G. Kreutz, S. Consonni. Combined Biomass and Black Liquor Gasifier/Gas Turbine Cogeneration at Pulp and Paper Mills. Trans. ASME, Vol. 121, July 1999.

5. E.D. Larson, T.G. Kreutz, S. Consonni. Preliminary Economics of Black Liquor Gasifier/Gas Turbine Cogeneration at Pulp and Paper Mills. Trans. ASME, Vol. 122, April 2000.

6. E.D. Larson, George W. McDonald, Wenrui Yang, Wm. James Frederick, Kristina lisa, Thomas G. Kreutz, Earl W. Malcolm, and Craig A. Brown. "A cost-benefit assessment of BLGCC technology." TAPPI Journal, Vol. 83, No. 6, June 2000.

7. Kaufman, Jerry J. Value Management. Crisp Publications, 1998.

8. Technical Association of the Pulp and Paper Industry, Inc. Forest, Wood \& Paper Industry Technology Summit Book (Draft). May 2001.

9. U.S. Department of Energy. Statement of Work. Contract \# DE-AM07-97ID13590, Task Order \# DE-AT07-01ID60457, March 2001.

10. U.S. Department of Energy, Energy Information Administration. Manufacturing Consumption of Energy. Report \#: DOE/EIA-0512 (94), December , 1997 
FOREST PRODUCTS INDUSTRY OF THE FUTURE

PORTFOLIO STUDY AND EVALUATION

Appendix A

Index of Projects Selected for Study 


\section{FOREST PRODUCTS INDUSTRY OF THE FUTURE}

PORTFOLIO STUDY AND EVALUATION

\begin{tabular}{|c|c|c|c|c|c|c|c|c|c|c|}
\hline \multicolumn{11}{|c|}{ OIT Forest Product Projects } \\
\hline \multicolumn{11}{|c|}{ Energy Performance } \\
\hline Item & Project & Recipient & $\begin{array}{l}\text { Contact } \\
\text { Phone } \\
\text { Email }\end{array}$ & OITIS & $\begin{array}{l}\text { Agrm't } \\
\text { Number }\end{array}$ & $\begin{array}{c}\text { Data } \\
\text { Sheet }\end{array}$ & Q'tly & Final & Prop. & $\begin{array}{l}\text { Metrics } \\
\text { Data } \\
\text { Sheet }\end{array}$ \\
\hline $0 \mathrm{a}$ & Biomass Gasification Combined Cycle & $\begin{array}{l}\text { Weyerhaeu } \\
\text { ser }\end{array}$ & Del Raymond & 707 & 96G010173 & $\mathrm{x}$ & & $\mathrm{X}$ & & \\
\hline $\mathrm{Ob}$ & $\begin{array}{l}\text { Demonstration of Black Liquor } \\
\text { Gasification at Big Island }\end{array}$ & $\begin{array}{l}\text { Georgia } \\
\text { Pacific }\end{array}$ & $\begin{array}{l}\text { Robert } \\
\text { DeCarrera }\end{array}$ & 1630 & $01 \mathrm{NT} 40850$ & & & & $\mathrm{X}$ & \\
\hline$\overline{1}$ & Multiport Cylinder Dryer Demonstration & ANL & Choi & 785 & NA & $\mathrm{X}$ & $\mathrm{x}$ & & $\bar{x}$ & multiport_demo.anl \\
\hline 2 & $\begin{array}{l}\text { Development of Methane DENOX } \\
\text { Reburning Process }\end{array}$ & IGT & Rabovitser & 933 & $99 \mathrm{GO10418}$ & $\mathrm{x}$ & $x$ & & $\mathrm{X}$ & methdenox02 \\
\hline 3 & Black Liquor Gasification Demonstration & G-P & DeCarrera & 993 & $99 I D 13818$ & & $x$ & & $\mathrm{X}$ & $\begin{array}{l}\text { total blg initiative.use } \\
\text { for G-P.02 }\end{array}$ \\
\hline 4 & $\begin{array}{l}\text { Intermediate-Sized Entrained Particles: } \\
\text { Characterization, Formation, and Control }\end{array}$ & SNL & Baxter & 1110 & NA & $\mathrm{X}$ & $x$ & & $x$ & $\begin{array}{l}\text { intermed- } \\
\text { sized.entrained.part.01 }\end{array}$ \\
\hline 5 & $\begin{array}{l}\text { 3-D Characterization of the Structure of } \\
\text { Paper and Paperboard and Their } \\
\text { Application to Optimize Drying and Water } \\
\text { Removal Processes and End-Use } \\
\text { Applications }\end{array}$ & U MN & Ramaswamy & 1166 & $001 D 13873$ & $\mathrm{x}$ & $x$ & & $\mathrm{X}$ & 3D paper chars. 01 \\
\hline
\end{tabular}


FOREST PRODUCTS INDUSTRY OF THE FUTURE

PORTFOLIO STUDY AND EVALUATION

\begin{tabular}{|c|c|c|c|c|c|c|c|c|c|c|}
\hline \multicolumn{11}{|c|}{ OIT Forest Product Projects } \\
\hline \multicolumn{11}{|c|}{ Environmental Performance } \\
\hline Item & Project & Recipient & $\begin{array}{l}\text { Contact } \\
\text { Phone } \\
\text { Email }\end{array}$ & OITIS & $\begin{array}{l}\text { Agrm't } \\
\text { Number }\end{array}$ & $\begin{array}{l}\text { Data } \\
\text { Sheet }\end{array}$ & Q'tly & Final & Prop. & $\begin{array}{l}\text { Metrics } \\
\text { Data } \\
\text { Sheet }\end{array}$ \\
\hline 6 & High Efficiency $\mathrm{ClO}_{2}$ Delignification & IPST & McDonough & 669 & $96 \mathrm{ID} 13442$ & $\mathrm{X}$ & $\mathrm{X}$ & & $\mathrm{X}$ & \\
\hline 7 & VOC Control in Kraft Mills & IPST & Zhu & 685 & $96 I D 13438$ & $\mathrm{x}$ & $\mathrm{X}$ & & $\mathrm{X}$ & $\begin{array}{l}\text { VOC_Control_- } \\
\text { continued.ipst }\end{array}$ \\
\hline 8 & Low VOC Drying of Lumber and Wood & IPST & Banerjee & 687 & $96 \mathrm{ID} 13439$ & $\bar{x}$ & $\bar{x}$ & & $x$ & lowvoc.RFwood.dry.01 \\
\hline 9 & Mill Designed Biobleaching Technologies & IPST & Ragauskas & 941 & 996010374 & $\mathrm{X}$ & $\mathrm{X}$ & & $\mathrm{X}$ & mill biobleach.01 \\
\hline 10 & $\begin{array}{l}\text { Water Recycling/Removal Using } \\
\text { Temperature Sensitive Hydrogels }\end{array}$ & Auburn & Gupta & 961 & 99G010417 & $x$ & $x$ & & $x$ & $\begin{array}{l}\text { water.recycle- } \\
\text { hydrogel. } 01\end{array}$ \\
\hline 11 & $\begin{array}{l}\text { Use of Residual Solids in Ready-Mixed } \\
\text { Concrete }\end{array}$ & UWI & Naik & 1150 & $001 D 13867$ & $x$ & $\mathrm{x}$ & & $\mathrm{X}$ & residual solids. 01 \\
\hline 12 & $\begin{array}{l}\text { Assessment of Low-Temperature Plasma } \\
\text { Technologies for Treating VOC Emissions } \\
\text { from Pulp Mills and Wood Product Plants }\end{array}$ & $\begin{array}{l}\text { U IL } \\
\text { Chicago }\end{array}$ & Fridman & 1151 & $001 D 13868$ & $\bar{x}$ & $x$ & & $x$ & plasmatech.VOC.01 \\
\hline 13 & $\begin{array}{l}\text { Control of Emissions from Wood Waste } \\
\text { Burners and Wood Dryers }\end{array}$ & UWA & Malte & 1152 & $001 \mathrm{D} 13869$ & $\bar{x}$ & $\mathrm{x}$ & Y'rly & $x$ & $\begin{array}{l}\text { Control.emiss.burners \& } \\
\text { dryers. } 01\end{array}$ \\
\hline 14 & $\begin{array}{l}\text { NPE Removal Using Functionalized } \\
\text { Monolayers on Mesoporus Supports }\end{array}$ & PNNL & $\begin{array}{l}\text { Robert } \\
\text { Leugemors }\end{array}$ & 1154 & NA & $x$ & $\mathrm{x}$ & Paper & $\mathrm{x}$ & npe removal3.01 \\
\hline
\end{tabular}




\section{FOREST PRODUCTS INDUSTRY OF THE FUTURE PORTFOLIO STUDY AND EVALUATION}

\begin{tabular}{|c|c|c|c|c|c|c|c|c|c|c|}
\hline \multicolumn{11}{|c|}{ OIT Forest Product Projects } \\
\hline \multicolumn{11}{|c|}{ Sustainable Forestry } \\
\hline Item & Project & Recipient & $\begin{array}{l}\text { Contact } \\
\text { Phone } \\
\text { Email }\end{array}$ & OITIS & $\begin{array}{l}\text { Agrm't } \\
\text { Number }\end{array}$ & $\begin{array}{l}\text { Data } \\
\text { Sheet }\end{array}$ & $Q^{\prime}$ tly & Final & Prop. & $\begin{array}{l}\text { Metrics } \\
\text { Data } \\
\text { Sheet }\end{array}$ \\
\hline 15 & $\begin{array}{l}\text { Effects of Fertilization and Competition } \\
\text { Control on Carbon and Nutrient Allocation } \\
\text { and Physiology in Loblolly Pine } \\
\text { Plantations }\end{array}$ & U GA & Hendrick & & $98 \mathrm{GO} 10363$ & & $\mathrm{X}$ & & & $\begin{array}{l}\text { effects.fertilization.on. } \\
\text { C,N,\&Phys.99 }\end{array}$ \\
\hline 16 & $\begin{array}{l}\text { Model-Based Diagnosis of Soil Limitations } \\
\text { to Forest Productivity }\end{array}$ & ORNL & Luxmoore & 677 & NA & $\mathrm{X}$ & $\mathrm{x}$ & & & model.diagnose.soil.01 \\
\hline 17 & $\begin{array}{l}\text { Development and Validation of Marker- } \\
\text { Aided Selection Methods for Wood } \\
\text { Property Traits in Loblolly and Poplar }\end{array}$ & ORNL & Tuskan & 681 & $\overline{N A}$ & $x$ & $\bar{x}$ & & $\bar{x}$ & \\
\hline 18 & $\begin{array}{l}\text { Molecular Physiology of Nitrogen } \\
\text { Allocation in Poplar }\end{array}$ & $\mathrm{UFL}$ & Davis & 758 & $97 \mathrm{ID} 13529$ & $\mathrm{X}$ & $\mathrm{x}$ & & $\bar{x}$ & $\begin{array}{l}\text { molec.physiol of } \\
\text { nitrogen. } 01\end{array}$ \\
\hline 19 & $\begin{array}{l}\text { Dominant Negative Mutations of Floral } \\
\text { Homeotic Genes for Genetic Engineering } \\
\text { of Sterility in Forest Trees }\end{array}$ & OSU & Brunner/Strauss & 794 & $97 \mid D 13552$ & $x$ & $\mathrm{X}$ & & $x$ & $\begin{array}{l}\text { DRAFT2.dom-neg } \\
\text { mutation. } 02\end{array}$ \\
\hline 20 & Pine Gene Discovery Project & NC State & Whetten & 795 & 97 ID13550 & $\mathrm{X}$ & $\mathrm{X}$ & Draft & $\mathrm{X}$ & pine gene. 01 \\
\hline
\end{tabular}


FOREST PRODUCTS INDUSTRY OF THE FUTURE PORTFOLIO STUDY AND EVALUATION

\begin{tabular}{|c|c|c|c|c|c|c|c|c|c|c|}
\hline \multicolumn{11}{|c|}{ OlT Forest Product Projects } \\
\hline \multicolumn{11}{|c|}{ Improved Capital Effectiveness } \\
\hline Item & Project & Recipient & $\begin{array}{l}\text { Contact } \\
\text { Phone } \\
\text { Email }\end{array}$ & OITIS & $\begin{array}{l}\text { Agrm't } \\
\text { Number }\end{array}$ & $\begin{array}{l}\text { Data } \\
\text { Sheet }\end{array}$ & Q'tly & Final & Prop. & $\begin{array}{l}\text { Metrics } \\
\text { Data } \\
\text { Sheet }\end{array}$ \\
\hline 21 & Lateral Corrugator & $\begin{array}{l}\text { United } \\
\text { Container }\end{array}$ & Agronin & 1481 & $01 \mathrm{G010616}$ & & $\mathrm{X}$ & & $\mathrm{X}$ & $\begin{array}{l}\text { lateral corrugator } \\
\text { Agronia-GPRA } \\
20020512\end{array}$ \\
\hline 22 & $\begin{array}{l}\text { Improving Dryer and Press Efficiencies } \\
\text { through the Combustion of Hydrocarbon } \\
\text { Emissions }\end{array}$ & IPST & Banerjee & 1482 & $01 \mathrm{GO10620}$ & & $\mathrm{X}$ & & $\mathrm{X}$ & $\begin{array}{l}\text { improve dry press } \\
\text { Banerjee-GPRA } \\
2002 \_0512\end{array}$ \\
\hline 23 & Directed Green Liquor Utilization Pulping & IPST & Lucia & 1483 & $01 \mathrm{G010626}$ & & $\mathrm{x}$ & & $\bar{x}$ & $\begin{array}{l}\text { novel pulping.D- } \\
\text { Glu.Lucia-2002 } 0512\end{array}$ \\
\hline 24 & High Capacity Gas-Fired Dryer & IGT & Kurek & 1484 & $01 \mathrm{GO10621}$ & & $\mathrm{X}$ & & $\mathrm{X}$ & high_cap_ppr_dryer.igt \\
\hline 25 & $\begin{array}{l}\text { Continuous Process for Displacement } \\
\text { Dewatering }\end{array}$ & Voith & Beck & 1485 & $01 \mathrm{G010622}$ & & $\mathrm{X}$ & & $\mathrm{X}$ & $\begin{array}{l}\text { proprietary.feasib.disp. } \\
\text { dewatering.Beck }\end{array}$ \\
\hline 26 & $\begin{array}{l}\text { Use of Borate Autocausticizing to } \\
\text { Supplement Lime Kiln and Causticizing } \\
\text { Capacities }\end{array}$ & W Ml U & Cameron & 1486 & $01 \mathrm{GO} 10623$ & & $\mathrm{X}$ & & $\mathrm{X}$ & $\begin{array}{l}\text { borate autocaust } \\
\text { Cameron }\end{array}$ \\
\hline 27 & Fast Curing of Composite Wood Products & IPST & Ragauskas & 1487 & $01 \mathrm{GO10625}$ & & $\mathrm{x}$ & & $\mathrm{x}$ & fast curing Ragauskas \\
\hline
\end{tabular}


FOREST PRODUCTS INDUSTRY OF THE FUTURE

PORTFOLIO STUDY AND EVALUATION

\begin{tabular}{|c|c|c|c|c|c|c|c|c|c|c|}
\hline \multicolumn{11}{|c|}{ OIT Forest Product Projects } \\
\hline \multicolumn{11}{|c|}{ Recycling } \\
\hline Item & Project & Recipient & $\begin{array}{c}\text { Contact } \\
\text { Phone } \\
\text { Email }\end{array}$ & OITIS & $\begin{array}{l}\text { Agrm't } \\
\text { Number }\end{array}$ & $\begin{array}{l}\text { Data } \\
\text { Sheet }\end{array}$ & Q'tly & Final & Prop. & $\begin{array}{c}\text { Metrics } \\
\text { Data } \\
\text { Sheet }\end{array}$ \\
\hline 28 & $\begin{array}{l}\text { Acoustic Separation (Underwater Pulsed } \\
\text { Power) Technology }\end{array}$ & IPST & Ahrens & 772 & 971013553 & $x$ & $x$ & & $x$ & acoustic sep.01 \\
\hline 29 & $\begin{array}{l}\text { Water Soluble and Easily Removable } \\
\text { Cationic Pressure Sensitive Adhesives }\end{array}$ & IPST & Deng & 944 & $99 G 010379$ & $x$ & $\bar{x}$ & & $x$ & Cat.PSAs.01 \\
\hline 30 & $\begin{array}{l}\text { Replacing Chemicals in Recycle Mills with } \\
\text { Mechanical Alternatives }\end{array}$ & IPST & Banerjee & 945 & $99 G 010381$ & $x$ & $x$ & & $x$ & repchem.01 \\
\hline$\overline{31}$ & $\begin{array}{l}\text { Surfactant Spray - A Novel Technology to } \\
\text { Improve Floatation Deinking }\end{array}$ & IPST & Zhu & 1198 & 001013879 & $\mathrm{X}$ & $x$ & & $x$ & surfsprtech.01 \\
\hline
\end{tabular}


FOREST PRODUCTS INDUSTRY OF THE FUTURE PORTFOLIO STUDY AND EVALUATION

\begin{tabular}{|c|c|c|c|c|c|c|c|c|c|c|}
\hline \multicolumn{11}{|c|}{ OIT Forest Product Projects } \\
\hline \multicolumn{11}{|c|}{ Sensors and Controls } \\
\hline Item & Project & Recipient & $\begin{array}{l}\text { Contact } \\
\text { Phone } \\
\text { Email }\end{array}$ & OITIS & $\begin{array}{l}\text { Agrm't } \\
\text { Number }\end{array}$ & $\begin{array}{l}\text { Data } \\
\text { Sheet }\end{array}$ & Q'tly & Final & Prop. & $\begin{array}{l}\text { Metrics } \\
\text { Data } \\
\text { Sheet } \\
\end{array}$ \\
\hline 32 & $\begin{array}{l}\text { Feedstock-to-Product Characterization } \\
\text { Tools for the Wood and Pulp Industry } \\
\text { AND/OR Development of a Field-Mobile } \\
\text { NIR for Measurement of Standing Wood } \\
\text { Properties }\end{array}$ & NREL & $\begin{array}{l}\text { Stephen Kelley } \\
\text { (303) } 3846123 \\
\text { stephen kelley@ } \\
\text { nrel.gov }\end{array}$ & 699 & $\overline{N A}$ & $x$ & $\mathrm{x}$ & & $\mathrm{X}$ & $\begin{array}{l}\text { feed to prod.99 } \\
\text { field mobile.NIR.01 }\end{array}$ \\
\hline 33 & $\begin{array}{l}\text { Distributed Web Sensor for On-Line } \\
\text { Measurement of Paper Basis Weight }\end{array}$ & PNNL & Griffin & 827 & NA & $\mathrm{X}$ & $\bar{x}$ & & $\mathrm{X}$ & $\begin{array}{l}\text { full web sensor Griffin- } \\
02\end{array}$ \\
\hline 34 & On Line Fluidics Controlled Headbox & IPST & Aidun & 975 & 99G010416 & $x$ & $\bar{x}$ & & $x$ & headbox-ipst.02 \\
\hline 35 & $\begin{array}{l}\text { Guided Acoustic Wave Monitoring of } \\
\text { Corrosion and Erosion of Recovery Boiler } \\
\text { Tubing }\end{array}$ & LLNL & Chinn & 1157 & NA & $x$ & $\mathrm{x}$ & & $x$ & $\begin{array}{l}\text { guided.monit.c\&e. } \\
\text { recovery.b.01 }\end{array}$ \\
\hline 36 & $\begin{array}{l}\text { Wireless Microwave Wood Moisture } \\
\text { Measurement }\end{array}$ & $\begin{array}{l}\text { U TN, } \\
\text { ORNL }\end{array}$ & Moschler & 1491 & $01 \mathrm{GO} 10618$ & & $x$ & & $\mathrm{X}$ & $\begin{array}{l}\text { wireless_microwave.U } \\
\text { of TN }\end{array}$ \\
\hline 37 & $\begin{array}{l}\text { CFD Modeling, Shape Optimization and } \\
\text { Feasibility Testing of Advanced Black } \\
\text { Liquor Nozzle Designs }\end{array}$ & INEEL & Detering & 1492 & NA & & $x$ & & $\bar{x}$ & CFD_Modeling.INEEL \\
\hline
\end{tabular}


FOREST PRODUCTS INDUSTRY OF THE FUTURE

PORTFOLIO STUDY AND EVALUATION

Appendix B

Instructions for Providing Technology Impact Projections 


\section{FOREST PRODUCTS INDUSTRY OF THE FUTURE \\ PORTFOLIO STUDY AND EVALUATION}

\section{Technology Impact Projections}

Revised 5/31/00

The Office of Industrial Technologies (OIT) needs to understand the impact on energy use, waste production, and production cost each technology or project is likely to have. Estimating the potential benefits and impacts which may accrue from the results of research, development, and demonstration (and related) projects is important for both existing and proposed projects. It is an important criterion in evaluating projects as well as in presenting the merits of both individual projects and, through aggregation, the overall portfolio of projects in a given area. The potential energy savings, types of energy saved, types of emissions reduced, and economic benefits are among the factors of importance.

Proposers responding to a Solicitation or Request for Proposals should review the governing documents for instructions on when and how to submit the necessary information; existing project managers/principle investigators should have received this request through an OIT program manager. A spreadsheet version of the Technology Impact Projection input forms and supporting information are on the same disk or e-mail you are using to read this message. It allows you to enter key information about your proposed technology and its expected market, and facilitates calculating the potential energy and emission reductions and other impacts of your project in a relatively rapid and consistent manner.

Please provide your best estimate for each piece of information required to complete the spreadsheet. Be realistic about your estimates: if you are awarded a contract, you will be required to update this information annually. Note that not all inputs are necessarily applicable or available for all possible technologies. If you can only estimate the differential between the proposed new and the current state-of-the-art technology, reflect that in the spreadsheet by setting values for the current technology to " 0 ". Placeholder values are included for some variables to (1) trigger the appearance of the Supplementary Table, which only appears if nonzero values are entered for use of feedstocks, renewables, waste, or "other" energy forms, and (2) illustrate where market data is entered on the sheet. These values must be changed to reflect your technology.

\section{Per Unit Impact}

Please provide key information on the performance of single installed units or applications of your technology. The performance of the new technology should be consistent with the performance goals in your proposal. For comparison, provide information on the performance of the best available technology for the application, not the average of all in-place technology units.

\section{Unit Description}

Describe what constitutes a typical process unit for your technology, in terms of annual output (production capacity times duty factor). For simplicity, the analysis will assume that all units in the industry have the same capacity. A realistic, average, or typical unit capacity should be chosen, particularly for situations where the unit size may vary in different installations. By convention and to enable comparisons, units for the new technology and the current state-of-the- 


\section{FOREST PRODUCTS INDUSTRY OF THE FUTURE PORTFOLIO STUDY AND EVALUATION}

art should be equal in output capacity, even if, in reality, the new technology might have a different capacity for various reasons.

The new technology also might not be a physical item of hardware. Rather, it could be a process change, a computer model or control system, operational change or other non-physical technique. In such cases, a unit should be defined as the typical or average process or plant that would utilize the new technique. The annual energy inputs based on the expected energy consumption of the process or plant with the new technique would then be compared with annual energy consumption required by existing techniques.

\section{Energy Use}

Please provide energy use per year for the new and conventional units, by fuel. If feedstock energy use is expected to change, it should be accounted for under Other. Please also indicate the price of any feedstock, renewable, waste, and other fuels on the supplementary table. Prices for waste used as fuels may be negative, reflecting the avoided cost of conventional waste disposal.

Electricity - Includes direct electricity.

Natural Gas - Includes pipeline fuel natural gas and compressed natural gas.

Petroleum - Includes distillate fuel, jet fuel, motor gasoline, residual fuel, liquid petroleum gas, and other petroleum.

Coal - Includes metallurgical coal, steam coal, and net coal coke imports.

Feedstock - Includes fossil fuels consumed in non-energy uses such as process feedstocks.

Biomass - Includes the use of biomass (for energy or as feedstock).

Wastes - Includes the use of fuels that are generated as wastes or process by-products. Examples of such fuels are refinery fuel gas, blast furnace gas, hog $\&$ bark fuel, and sewage sludge.

Total Primary Energy - Is calculated from individual energy inputs. Note that the primary equivalent of direct electricity consumption includes losses in electricity generation and distribution.

\section{Environmental}

Environmental impacts of your new technology can generally be divided into impacts that are a direct result of energy savings and non-energy-savings-related emissions impacts. The energysavings-related environmental emissions are calculated automatically by the spreadsheet from the energy savings (and fuel substitutions or use of renewable energy) and typical emissions factors for various fuels and electricity use. The spreadsheet contains emission factors for electricity and fossil fuels. You may enter emission factors for feedstocks, renewables, wastes, or other fuels needed to assess your technology on the supplementary table included with the spreadsheet system.

Please provide estimates for the non-energy-related waste production associated with the new and conventional technologies. Please specify what type of solid waste is being affected, if any.

Other Greenhouse Emissions Displaced

Estimate of the amount of greenhouse emissions other than $\mathrm{CO}_{2}, \mathrm{No}_{\mathrm{x}}$, and VOCs if germane to your technology. These could include methane, perflourocarbons, or other gases. Identify which gas and insert the appropriate multiplier for that gas as provided in the attached tables. The 


\section{FOREST PRODUCTS INDUSTRY OF THE FUTURE PORTFOLIO STUDY AND EVALUATION}

spreadsheet allows for three such other gases; if more are involved in your process, the carbon equivalent can be calculated separately, summed and inserted. An explanation should be provided.

\section{Cost}

Please provide rough estimates of the initial capital cost and non-energy variable costs associated with your technology new and old on a per-unit basis. Leave these blanks if you do not know the impact. Non-energy costs are non-fuel related annual costs that are affected by the technology substitution. This should include items such as operation and maintenance costs.

\section{Market Projects and Impacts}

To determine the potential impact of the new technology as it becomes adopted, it is necessary to estimate the total market for the technology, reduce that to the likely actual market, and estimate when and the rate at which the new technology will penetrate the market.

\section{Total Market}

The next step in projecting the overall potential impact of your technology is to identify the total market: the number of units that perform the same task as your proposed technology. Only the domestic U.S. market should be included. World market and export potential are important factors which may be considered separately, but this analysis is to estimate domestic energy and emissions reduction impacts.

\section{Number of Units in Total Market}

Please define that market as narrowly as possible: i.e. the smallest group of applications that covers all potential applications that you may have some data for. You may base your estimate on the energy use of the state-of-the-art technology and the energy use data provided in this package. Please also indicate for which year the data that you provided applies.

\section{Overall Market Growth Rate}

Is provided by OIT and based on EIA's projection of macroeconomic trends over future years.

\section{Potential Market Share}

Please estimate the accessible market: the market that the new technology could reasonably access given technical, cost, and other limitations of the technology. For example, certain technologies may only be applicable to a certain scale of plant, certain temperature range processes, certain types of existing equipment or subsystems, or only certain segments of the industry.

\section{Likely Market Share}

In some instances, in addition to technical and cost factors, your technology may compete with other new technology approaches, or with other companies for the market. Please estimate the likely market share. Use current market share information or base your estimate market share on the basis of the number of competitors in the market, assuming they are using different technologies not resulting from this project. This is different than the possibility of "copycats" 


\section{FOREST PRODUCTS INDUSTRY OF THE FUTURE \\ PORTFOLIO STUDY AND EVALUATION}

which should not be considered as competing. That is, if others adopt essentially the same, or slightly modified, technology due to this new technology, that adoption was triggered by the project being described and that project should be "credited" with causing that trend. This is potentially the case for techniques where the intellectual property cannot be, or is not, protected and becomes general knowledge throughout the industry.

\section{Market Penetration}

To understand how rapidly the potential impact of the technology may be felt, the market penetration of the technology must be projected. Please indicate when the technology is likely to be introduced to the market on a commercial or similar basis. This date should be consistent with your technology development program plans. The date will normally occur after a significant demonstration or operating prototype and after an adequate test and evaluation period along with allowances for the beginnings of production, dissemination of information, initial marketing and sales or other "start up" factors.

New technologies normally penetrate a market following a familiar "s" curve, the lower end representing the above uncertainties overcome by "early adopters." The curve tails off at the far future where some may never adopt the new technology. Of importance is the major portion of the " $\mathrm{s}$ " curve where the new technology is penetrating the market and benefits are being reaped. The rate at which technologies penetrate their markets varies significantly: penetrations of heavy industrial technologies generally takes place over decades, while simple process or control changes can penetrate much more rapidly. The actual penetration rate varies due to economic, environmental, competitive position, productivity, regulatory, and other factors.

To assist you, a large volume of actual penetration rates of past and present technologies were analyzed, normalized, and grouped into five classes based on a number of characteristics and criteria (see Figure 1 below). In Table I, circle the class (column) which you believe your technology best fits for each characteristic (row). Note that the characteristics (rows) are relatively independent and a given technology will likely fit best in different classes for different characteristics. By examining the pattern, however, one can, based on best judgement and experience, select the most likely class (rate) at which the new technology may penetrate the market. This may be a "subjective average" of the circled best fits, or it may be that one or two characteristics are believed to so dominate future adoption decisions that a particular class of penetration rate is justified. There also may be "windows of opportunity" where significant replacements of existing equipment may be expected to occur at some point in the future for other reasons. The proposer should insert into the spread sheet the class of penetration rate believed most likely, all things considered, and provide a narrative of the rationale for selection if not obvious from Table I.

If your completed spreadsheet will be delivered in hardcopy only, please attach a copy of the completed Table I to the printout of the spreadsheet together with any supporting information. If your completed spreadsheet will be delivered in electronic form, please enter X's in the cells of Table I instead of circling the hardcopy, save the changes, and deliver the instruction file (Tech Imp Projections4.wpd) as well as the completed spreadsheet file. 


\section{FOREST PRODUCTS INDUSTRY OF THE FUTURE \\ PORTFOLIO STUDY AND EVALUATION}

For additional assistance, Table II shows actual technologies and the class of their historical penetration rates. Comparison of the new technology, by analogy or similarity, with these examples provides additional in site into selecting the appropriate penetration rate that might be expected for the new technology. The spreadsheet, based on the unit performance, market size, and penetration rate class, will then calculate the estimated overall energy and environmental impacts and benefits over time which the new technology may bring to the industry and to the nation. 


\section{Table I. Selecting the Market Penetration Rate Class}

\begin{tabular}{|c|c|c|c|c|c|}
\hline Characteristic & A & B & $\mathrm{C}$ & $\mathrm{D}$ & E \\
\hline Time to Saturation (ts) & $5 \mathrm{yrs}$ & $10 \mathrm{yrs}$ & $20 \mathrm{yrs}$ & 40 yrs & $>40 \mathrm{yrs}$ \\
\hline \multicolumn{6}{|l|}{ Technology Factors } \\
\hline Payback* discretionary & $<<1$ yrs & $<1$ yrs & $1-3$ yrs & $3-5 \mathrm{yrs}$ & $>5 \mathrm{yrs}$ \\
\hline $\begin{array}{l}\text { Payback* non- } \\
\text { discretionary }\end{array}$ & $\ll<1$ yrs & $<1 \mathrm{yrs}$ & $1-2$ yrs & $2-3$ yrs & $>3 \mathrm{yrs}$ \\
\hline Equipment life & $<5$ yrs & $5-15 \mathrm{yrs}$ & $15-25 \mathrm{yrs}$ & $25-40$ yrs & $>40 \mathrm{yrs}$ \\
\hline Equipment replacement & None & Minor & $\begin{array}{c}\text { Unit } \\
\text { operation }\end{array}$ & $\begin{array}{l}\text { Plant } \\
\text { section }\end{array}$ & $\begin{array}{l}\text { Entire } \\
\text { plant }\end{array}$ \\
\hline Impact on product quality & ++ & ++ & ++ & + & $\mathrm{O} /-$ \\
\hline $\begin{array}{l}\text { Impact on plant } \\
\text { productivity }\end{array}$ & ++ & ++ & ++ & + & $\mathrm{O} /-$ \\
\hline Technology experience & $\begin{array}{l}\text { New to } \\
\text { US only }\end{array}$ & $\begin{array}{l}\text { New to } \\
\text { US only }\end{array}$ & $\begin{array}{l}\text { New to } \\
\text { industry }\end{array}$ & New & New \\
\hline \multicolumn{6}{|l|}{ Industry Factors } \\
\hline Growth (\%p.a.) & $>5 \%$ & $>5 \%$ & $2-5 \%$ & $1-2 \%$ & $<1 \%$ \\
\hline Attitude to risk & open & open & cautious & $\begin{array}{c}\text { conservativ } \\
\mathrm{e}\end{array}$ & averse \\
\hline External Factors & forcing & forcing & driving & none & none \\
\hline \multicolumn{6}{|l|}{ Gov't regulation } \\
\hline Other & & & & & \\
\hline
\end{tabular}

* Payback is defined as capital outlay for new technology divided by savings before taxes and depreciation. In the case of Discretionary investments (i.e. replacements of existing equipment before the end of its economic life), capital outlay is total cost of new technology. In the case of non-discretionary investments (i.e.

replacements of existing equipment at the end of its economic life and new installations), capital is the capital cost of the new technology - capital cost of current technology.

\section{You can circle the criteria that apply to your technology and identify which category fits best.}




\section{Table II. Examples}

\begin{tabular}{|c|c|c|c|c|c|}
\hline Class & A & B & $\mathrm{C}$ & D & $\mathrm{E}$ \\
\hline Aluminum & & $\begin{array}{l}\text { Treatment of } \\
\text { used cathode } \\
\text { liners }\end{array}$ & $\begin{array}{l}\text { Strip casting, } \\
\text { VOC incinerators }\end{array}$ & & \\
\hline Chemicals & $\begin{array}{l}\text { New series of } \\
\text { dehydrogenation } \\
\text { catalyst } \\
\text { (incremental } \\
\text { change) }\end{array}$ & $\begin{array}{l}\text { CFCs }->\text { HCFCs, } \\
\text { incrementally } \\
\text { improved } \\
\text { catalysts, } \\
\text { membrane-baed } \\
\text { chlor-alkali }\end{array}$ & $\begin{array}{l}\text { Polypropylene } \\
\text { catalysts, solvent } \\
\text { to water-based } \\
\text { paints, PPE- } \\
\text { based AN }\end{array}$ & $\begin{array}{l}\text { Synthetic rubber } \\
\text { \& fibers }\end{array}$ & \\
\hline Forest Products & & & $\begin{array}{l}\text { Impulse drying, } \\
\text { de-inking of } \\
\text { waste newspaper }\end{array}$ & $\begin{array}{l}\text { Kraft pulping, } \\
\text { continuous paper } \\
\text { machines }\end{array}$ & \\
\hline Glass & & $\begin{array}{l}\text { Lubbers glass } \\
\text { blowing, } \\
\text { Pilkington float } \\
\text { glass }\end{array}$ & $\begin{array}{l}\text { Particulate } \\
\text { control, } \\
\text { regenerative } \\
\text { melters, } \\
\text { oxygenase in } \\
\text { glass furnaces }\end{array}$ & & \\
\hline Metals Casting & $\begin{array}{l}\text { New shop floor } \\
\text { practice }\end{array}$ & & & & \\
\hline Petroleum & $\begin{array}{l}\text { New series HDS } \\
\text { catalysts }\end{array}$ & $\begin{array}{l}\text { Alkylation } \\
\text { gasoline }\end{array}$ & $\begin{array}{l}\text { Thermal } \\
\text { cracking, } \\
\text { catalytic cracking }\end{array}$ & $\begin{array}{l}\text { Residue } \\
\text { gasification, } \\
\text { flexicoking }\end{array}$ & \\
\hline Steel & $\begin{array}{l}\text { Improved EAF } \\
\text { operating practice } \\
\text { (e.g. modify } \\
\text { electric/ burner } \\
\text { heating cycle to } \\
\text { minimize dust } \\
\text { generation) }\end{array}$ & $\begin{array}{l}\text { BOF steel } \\
\text { making }\end{array}$ & $\begin{array}{l}\text { Oxyfuel burners } \\
\text { for steel, Level II } \\
\text { reheat furnace } \\
\text { controls, } \\
\text { Continuous } \\
\text { casting, } \\
\text { particulate } \\
\text { control on EAF, } \\
\text { Hightop pressure } \\
\text { blast furnace }\end{array}$ & $\begin{array}{l}\text { Open hearth } \\
\text { technology, EAF } \\
\text { technology }\end{array}$ & \\
\hline Other & & $\begin{array}{l}\text { Advanced } \\
\text { refrigerator } \\
\text { compressors, } \\
\text { oxygen flash } \\
\text { copper smelting, } \\
\text { solvent } \\
\text { extraction with } \\
\text { liquid ion } \\
\text { exchange }\end{array}$ & $\begin{array}{l}\text { Fluegas } \\
\text { desulfurization } \\
\text { (coal-fired } \\
\text { utilities), low } \\
\text { Nox industrial } \\
\text { burners, } \\
\text { industrial gas } \\
\text { turbines, ore } \\
\text { beneficiation }\end{array}$ & & $\begin{array}{l}\text { Dry-kiln cement, } \\
\text { industrial } \\
\text { ceramic } \\
\text { recuperators } \\
\text { Industrial heat } \\
\text { pumps }\end{array}$ \\
\hline & & & & & \\
\hline
\end{tabular}

\section{If you can think of good examples for your industry, we'll add them!}


ерuәб $\forall$ uo!̣ssnos!̣

$x ! p u ə d d \forall$ 
FOREST PRODUCTS INDUSTRY OF THE FUTURE

PORTFOLIO STUDY AND EVALUATION

Discussion Agenda (initial)

Project Title OTIS Number

Date of Discussion Phone Number LATA Item

Discussion Participants, Organization-

Background:

Opportunity/Problem being addressed:

Commercialization discussion:

Strategic competitive position:

Environmental benefits:

Energy benefits:

GPRA Metrics discussion/thoughts about accuracy and advisable changes to estimating process:

Current energy markets discussion:

Breakthroughs / Scientific Insights:

National Impacts:

Other: 


\section{FOREST PRODUCTS INDUSTRY OF THE FUTURE}

PORTFOLIO STUDY AND EVALUATION

Principal Investigator Discussion Agenda (revised)

Project Number:

OITIS Number:

Project Title:

Date of Discussion:

Discussion Initiator:

Principal Investigator/Organization:

\section{PROJECT BACKGROUND}

\section{EVALUATION PARAMETERS}

Sustained forest resource management:

Size and extent of market for the new technology:

Energy performance:

Economic attractiveness:

Technology champion:

Scientific insights derived from project:

Improved environmental performance:

Technological leadership:

Recycled wood and paper materials:

Risk:

Alternate uses for biomass: 


\section{FOREST PRODUCTS INDUSTRY OF THE FUTURE PORTFOLIO STUDY AND EVALUATION}

\section{Schedule-Based Approach to Portfolio Evaluation}

One of the more difficult challenges of the study was the search for a meaningful and useful way to relate the results of the project evaluations to the Agenda 2020 R\&D pathways in a fashion that conveyed a sense of direction and progress over time. An examination of the Agenda 2020 Implementation Plan revealed twenty-five R\&D pathways covering the six technology areas of the program. Each of these pathways was characterized by the identification of a number of focus areas, continuing research areas, future research directions, knowledge and tools to be delivered and assimilated, and results to be realized. The data defining these pathways was excerpted from the plan, compiled, and presented in Appendix E. Although the characterization was presented in a logical format, this logic did not lend itself readily to association with timelines or schedule milestones. However, the descriptions of the continuing research areas and the future research directions had the possibility of being associated with the portfolio of projects and with time in a broad sense. A Gantt chart format was developed to show the areas of continuing research and future research as individual bars on a schedule. An arbitrary date of the end of year 2005 was established as the cutoff date for continuing research and the beginning date for future research. Future research was assumed to complete at the end of year 2020 . The projects being evaluated were then associated with the particular pathway that appeared to provide the best fit. Since the projects being evaluated in this study were either completed or underway, they all fit within the category of continuing research. Each of these projects were shown as individual tasks on the schedule with project start and finish dates that were taken from project information sheets. To relate these project task bars with the project evaluations, circles were superimposed over the project task bars and numerical, weighted ratings were inserted within the circles for those projects that had been evaluated up to that time. A Gantt chart was developed in this manner for each of the twenty-five pathways and the most complete of these was presented to the Steering Group for review and discussion.

This presentation led to several observations that argued against pursuing a schedule-based approach. First, there are no clear one-to-one relationships between individual projects and the R\&D pathways as evidenced by cases where particular projects could reasonably span a number of R\&D pathways. Second, by reducing the number of projects to be considered in this study to a subset of the total number of projects in the Agenda 2020 portfolio, important R\&D activity is not represented which can lead to invalid conclusions as to whether all of the pathways are being adequately addressed by the Agenda 2020 program. Third, the descriptions for many of the areas of research do not correlate well with either future areas of research or with specific projects, which makes it difficult to envision logical paths forward. Fourth, for the most part there are few apparent, logical relationships between individual projects, which hinders the use of this approach as a management tool. Fifth, there is an underlying philosophical disconnect regarding the application of schedule-based techniques to the evaluation of a program that spans the spectrum of the Agenda 2020 projects. While it might be useful when projects are in their latter stages of technology demonstration and fairly well-defined, it is inadequate for understanding those projects that are in the beginning stages of fundamental research where specific objectives that are related to follow-on projects are unknown or vague. On the other hand, the schedule-based approach did point out the need for a means define follow-on projects more clearly for future solicitations. An example of this was the apparent absence of any gas turbine or heat recovery steam generator development/demonstration projects although they would be necessary to achieve the goal of demonstrating an integrated gasification combined cycle (IGCC) plant. As a result of these observations it was decided to abandon the schedule-based approach in order to seek out one that would be a better fit. 


\section{FOREST PRODUCTS INDUSTRY OF THE FUTURE \\ PORTFOLIO STUDY AND EVALUATION}

\section{Report Card Analogy for Project Evaluation}

The Project Evaluation System can yield a mathematical maximum score of 400 . Such a score is practically impossible, even for a "perfect" project since some of the parameters of evaluation tend towards mutual exclusivity. However, the concept of achieving a score would facilitate using a report card system like that used in academia. It would even be possible to grade the projects evaluated "on a curve". The problem with this approach is that it could unfairly represent those projects that received scores on the low end of the scale as "barely passing" or even "failing" when, in fact, all of the projects evaluated in this study were chosen on the basis of their positive merits and contributions to the Agenda 2020 program. Any score, including a low score, must be interpreted within the context of the evaluation parameters. It is possible for some projects to be remarkably successful and still receive a low score because some of the parameters for evaluation simply don't apply to that particular project. Because of the potential for misinterpretation and confusion, the report card system was also abandoned for this project. 
FOREST PRODUCTS INDUSTRY OF THE FUTURE

PORTFOLIO STUDY AND EVALUATION

Appendix $E$

Individual Project Rating Sheets 


\section{FOREST PRODUCTS INDUSTRY OF THE FUTURE - PORTFOLIO STUDY AND EVALUATION}

\section{1-785 Multiport Cylinder Dryer}

\begin{tabular}{|c|c|c|c|c|c|c|c|}
\hline 1 & $\begin{array}{l}\text { Sustained forest resource } \\
\text { management }\end{array}$ & 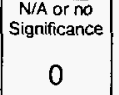 & $\begin{array}{c}\text { Some } \\
\text { significance } \\
1\end{array}$ & 2 & $\begin{array}{c}\text { Moderate } \\
\text { Significance } \\
3\end{array}$ & 4 & $\begin{array}{c}\text { Aligh } \\
\text { Significance } \\
5 \\
5\end{array}$ \\
\hline 2 & $\begin{array}{l}\text { Size and extent of market } \\
\text { tor the new technology }\end{array}$ & \begin{tabular}{|c|} 
Very Small \\
0
\end{tabular} & $\begin{array}{c}\text { Smail } \\
1\end{array}$ & 2 & $\begin{array}{c}\text { Medium } \\
3\end{array}$ & 4 & $\begin{array}{l}\text { Large } \\
5\end{array}$ \\
\hline 3 & Energy performance & \begin{tabular}{|c|} 
N/A or no \\
Significance \\
0 \\
0
\end{tabular} & \begin{tabular}{|c|}
$\begin{array}{c}\text { Some } \\
\text { Significance } \\
1\end{array}$ \\
\end{tabular} & 2 & $\begin{array}{c}\text { Moderate } \\
\text { Signiificance } \\
3\end{array}$ & 4 & $\begin{array}{c}\begin{array}{c}\text { High } \\
\text { Significance } \\
5 \\
5\end{array} \\
\end{array}$ \\
\hline 4 & Economic attractiveness & $\begin{array}{c}\text { Unattractive } \\
0\end{array}$ & $\begin{array}{c}\text { Somewhiat } \\
\text { Attradive } \\
1\end{array}$ & 2 & $\begin{array}{c}\text { Attradive } \\
3\end{array}$ & 4 & \begin{tabular}{|c|} 
Highly \\
Attractive \\
5 \\
5
\end{tabular} \\
\hline 5 & Technology champion & $\begin{array}{c}\text { None } \\
0 \\
0\end{array}$ & \begin{tabular}{|c} 
Assigned \\
Cnampion \\
1
\end{tabular} & 2 & $\begin{array}{c}\text { Independert } \\
\text { Champion } \\
3\end{array}$ & 4 & \begin{tabular}{|c|} 
Mututiple \\
Champions \\
5 \\
5
\end{tabular} \\
\hline 6 & $\begin{array}{l}\text { Scientific insignts derived } \\
\text { from project }\end{array}$ & \begin{tabular}{|c|} 
N/A or no \\
Significance \\
0 \\
\end{tabular} & \begin{tabular}{|c|} 
Some \\
Significance \\
1
\end{tabular} & 2 & $\begin{array}{c}\text { Moderate } \\
\text { Significance } \\
3 \\
3\end{array}$ & 4 & $\begin{array}{l}\text { High } \\
\text { Significance } \\
5\end{array}$ \\
\hline 7 & $\begin{array}{l}\text { Improved environmental } \\
\text { performance }\end{array}$ & \begin{tabular}{|c|} 
N/A or no \\
Significance \\
0 \\
\end{tabular} & \begin{tabular}{|c|} 
Some \\
Significance \\
1 \\
1
\end{tabular} & 2 & $\begin{array}{c}\text { Moderate } \\
\text { Significance } \\
3 \\
3\end{array}$ & 4 & \begin{tabular}{|c|c|}
$\begin{array}{c}\text { High } \\
\text { Significance } \\
5 \\
5\end{array}$ \\
\end{tabular} \\
\hline 8 & Tectnological leadership & \begin{tabular}{|c|} 
N/A or no \\
Significance \\
0 \\
\end{tabular} & \begin{tabular}{|c|} 
Some \\
Significance \\
1 \\
\end{tabular} & 2 & $\begin{array}{c}\text { Moderate } \\
\text { Significance } \\
3 \\
3\end{array}$ & 4 & \begin{tabular}{|c} 
High \\
Significance \\
5 \\
5
\end{tabular} \\
\hline 9 & $\begin{array}{l}\text { Recycled wood and paper } \\
\text { materials }\end{array}$ & \begin{tabular}{|c|} 
N/A or no \\
Significance \\
0 \\
\end{tabular} & \begin{tabular}{|c|} 
Some \\
Significance \\
1
\end{tabular} & 2 & $\begin{array}{c}\text { Moderate } \\
\text { Significance } \\
3 \\
3\end{array}$ & 4 & \begin{tabular}{|c} 
High \\
Significance \\
5 \\
5
\end{tabular} \\
\hline 10 & Risk & $\begin{array}{c}\text { High Risk } \\
0\end{array}$ & \begin{tabular}{|c|}
$\begin{array}{c}\text { Moderate } \\
\text { Risk }\end{array}$ \\
1
\end{tabular} & 2 & \begin{tabular}{|c|} 
Low Risk \\
3 \\
\end{tabular} & 4 & \begin{tabular}{|c|} 
Very Low \\
Risk \\
5
\end{tabular} \\
\hline 11 & Altemate uses for biomass & \begin{tabular}{|c|} 
N/A or no \\
Significance \\
0 \\
\end{tabular} & \begin{tabular}{|c|} 
Some \\
Significance \\
1 \\
\end{tabular} & 2 & $\begin{array}{c}\text { Moderate } \\
\text { Significance } \\
3 \\
3\end{array}$ & 4 & \begin{tabular}{|c} 
High \\
Significance \\
5 \\
5
\end{tabular} \\
\hline
\end{tabular}

Totals

\begin{tabular}{|c|c|c|}
\hline $\begin{array}{c}\text { CTO } \\
\text { Weighting }\end{array}$ & $\begin{array}{l}\text { Raw } \\
\text { Rating }\end{array}$ & $\begin{array}{l}\text { Weighted } \\
\text { Rating }\end{array}$ \\
\hline 10 & 0 & 0 \\
\hline $\begin{array}{c}\text { CTO } \\
\text { Weighting }\end{array}$ & $\begin{array}{l}\text { Raw } \\
\text { Rating }\end{array}$ & $\begin{array}{l}\text { Weighted } \\
\text { Rating }\end{array}$ \\
\hline 9 & 5 & 45 \\
\hline $\begin{array}{c}\text { CTO } \\
\text { Weighting }\end{array}$ & $\begin{array}{l}\text { Raw } \\
\text { Rating }\end{array}$ & $\begin{array}{c}\text { Weighted } \\
\text { Rating }\end{array}$ \\
\hline 8 & 2 & 16 \\
\hline $\begin{array}{c}\text { CT̃O } \\
\text { Weighting }\end{array}$ & $\begin{array}{l}\text { Raw } \\
\text { Rating }\end{array}$ & $\begin{array}{c}\text { Weighted } \\
\text { Rating }\end{array}$ \\
\hline 8 & 5 & 40 \\
\hline $\begin{array}{c}\text { CTO } \\
\text { Weighting }\end{array}$ & $\begin{array}{l}\text { Raw } \\
\text { Rating }\end{array}$ & $\begin{array}{c}\text { Weighted } \\
\text { Rating }\end{array}$ \\
\hline 7 & 2 & 14 \\
\hline $\begin{array}{c}\text { CTO } \\
\text { Weighting }\end{array}$ & $\begin{array}{l}\text { Raw } \\
\text { Rating }\end{array}$ & $\begin{array}{c}\text { Weighted } \\
\text { Rating }\end{array}$ \\
\hline 7 & 3 & 1 \\
\hline $\begin{array}{c}\text { CTO } \\
\text { Weighting }\end{array}$ & $\begin{array}{l}\text { Raw } \\
\text { Rating }\end{array}$ & $\begin{array}{c}\text { Weighted } \\
\text { Rating }\end{array}$ \\
\hline 7 & 1 & 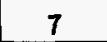 \\
\hline $\begin{array}{c}\text { CTO } \\
\text { Weighting }\end{array}$ & $\begin{array}{l}\text { Raw } \\
\text { Rating }\end{array}$ & $\begin{array}{c}\text { Weighted } \\
\text { Rating }\end{array}$ \\
\hline 7 & 4 & 20 \\
\hline $\begin{array}{c}\text { CTO } \\
\text { Weighting }\end{array}$ & $\begin{array}{l}\text { Raw } \\
\text { Rating }\end{array}$ & $\begin{array}{c}\text { Weighted } \\
\text { Rating }\end{array}$ \\
\hline 6 & 0 & 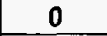 \\
\hline $\begin{array}{c}\text { CTO } \\
\text { Weighting }\end{array}$ & $\begin{array}{l}\text { Raw } \\
\text { Rating }\end{array}$ & $\begin{array}{c}\text { Weighted } \\
\text { Rating }\end{array}$ \\
\hline 6 & 5 & 20 \\
\hline $\begin{array}{c}\text { CTO } \\
\text { Weighting }\end{array}$ & $\begin{array}{l}\text { Raw } \\
\text { Rating }\end{array}$ & $\begin{array}{c}\text { Weighted } \\
\text { Rating }\end{array}$ \\
\hline 5 & 0 & 0 \\
\hline & 27 & 201 \\
\hline
\end{tabular}

Comments

\begin{tabular}{|l|}
\hline Not applicable. \\
\hline $\begin{array}{l}\text { Because this technology addresses the largest energy usage in papermaking and it will be } \\
\text { retrofitable to existing machines, the market includes the entire paper machine installed base } \\
\text { plus the new machine market as well. Technology is transferable to drum drying applications } \\
\text { in other industries. (Boric acid, powdered milk, other powdered or granular slurry operations.) }\end{array}$ \\
\hline $\begin{array}{l}\text { Technology deals with increasing the heat transfer and ultimately allowing drying at higher } \\
\text { machine speeds. Energy consumption per ton is unaffected. Motive power consumption will } \\
\text { be reduced because of removal of "rimmed" condensate from the system. }\end{array}$ \\
\hline $\begin{array}{l}\text { Economically attractive for two main reasons } 1 \text { ) the retrofit cost is estimated to be } \\
\text { approximately } 20 \% \text { of new cost. } 2 \text { ) the higher heat transfer allows several options - a) running } \\
\text { the machine at higher speed, b) reconfiguring the machine with fewer dryer cylinders and } \\
\text { using the space for a longer press. }\end{array}$ \\
\hline Design of lighter weight cylinders having no pressure vessel requirements. \\
\hline Not applicable. \\
\hline Project is very low risk. Device will be retrofitable to existing dryers at an reasonable cost, \\
estimated to be about \$10k per cylinder. \\
\hline
\end{tabular}




\section{FOREST PRODUCTS INDUSTRY OF THE FUTURE - PORTFOLIO STUDY AND EVALUATION}

02-933 Methane DeNox

\begin{tabular}{|c|c|c|c|c|c|c|c|}
\hline 1 & $\begin{array}{l}\text { Sustained forest resource } \\
\text { management }\end{array}$ & $\begin{array}{c}\text { N/A or no } \\
\text { Significance } \\
0\end{array}$ & $\begin{array}{c}\text { Some } \\
\text { Significance }\end{array}$ & & \begin{tabular}{c|} 
Moderate \\
Significance \\
\end{tabular} & 4 & $\begin{array}{c}\text { High } \\
\text { Significance } \\
5 \\
5\end{array}$ \\
\hline \multirow{3}{*}{2} & & & & & & & \\
\hline & & & & & (1) & & \\
\hline & tor the new technology & 0 & 1 & 2 & 3 & 4 & 5 \\
\hline \multirow{2}{*}{3} & \multirow{2}{*}{ Energy performance } & \begin{tabular}{|l} 
N/A or no \\
Significance
\end{tabular} & $\begin{array}{l}\text { Some } \\
\text { Significance }\end{array}$ & & $\begin{array}{l}\text { Moderate } \\
\text { Significance }\end{array}$ & & $\begin{array}{l}\text { High } \\
\text { Significance }\end{array}$ \\
\hline & & 0 & 1 & 2 & 3 & 4 & 5 \\
\hline \multirow{2}{*}{4} & \multirow{2}{*}{ Economic attraativeness } & & $\begin{array}{l}\text { Somewhat } \\
\text { Atractive }\end{array}$ & & Attractive & & $\begin{array}{c}\text { Highly } \\
\text { Atractive }\end{array}$ \\
\hline & & 0 & 1 & 2 & 3 & 4 & 5 \\
\hline \multirow{2}{*}{5} & \multirow{2}{*}{ Technology champion } & & $\begin{array}{l}\text { Assigned } \\
\text { Champion }\end{array}$ & & \begin{tabular}{|l|} 
Independent \\
Champion
\end{tabular} & & $\begin{array}{l}\text { Muthiple } \\
\text { Champions }\end{array}$ \\
\hline & & 0 & 1 & 2 & 3 & 4 & 5 \\
\hline \multirow{2}{*}{6} & \multirow{2}{*}{$\begin{array}{l}\text { Scientific insights derived } \\
\text { from project }\end{array}$} & $\begin{array}{l}\text { N/A or no } \\
\text { Significance }\end{array}$ & $\begin{array}{c}\text { Some } \\
\text { Significance }\end{array}$ & & \begin{tabular}{|l|} 
Moderate \\
Significance \\
\end{tabular} & & $\begin{array}{c}\text { High } \\
\text { Significance }\end{array}$ \\
\hline & & 0 & 1 & 2 & 3 & 4 & 5 \\
\hline \multirow{2}{*}{7} & \multirow{2}{*}{$\begin{array}{l}\text { Improved environmental } \\
\text { performance }\end{array}$} & $\begin{array}{l}\text { N/A or no } \\
\text { Significance }\end{array}$ & $\begin{array}{l}\text { Some } \\
\text { Significance }\end{array}$ & & \begin{tabular}{|l|} 
Moderate \\
Significance
\end{tabular} & & $\begin{array}{c}\text { High } \\
\text { Significance }\end{array}$ \\
\hline & & 0 & 1 & 2 & 3 & 4 & 5 \\
\hline \multirow{2}{*}{8} & \multirow{2}{*}{ Technological leadership } & \begin{tabular}{|l|} 
N/A or no \\
Significance
\end{tabular} & $\begin{array}{c}\text { Some } \\
\text { Significance }\end{array}$ & & \begin{tabular}{|l|} 
Moderate \\
Significance \\
\end{tabular} & & $\begin{array}{l}\text { High } \\
\text { Significance }\end{array}$ \\
\hline & & 0 & 1 & 2 & 3 & 4 & 5 \\
\hline \multirow{2}{*}{9} & \multirow{2}{*}{$\begin{array}{l}\text { Recycled wood and paper } \\
\text { materials }\end{array}$} & \begin{tabular}{|l|} 
N/A or no \\
Significance
\end{tabular} & $\begin{array}{c}\text { Some } \\
\text { Significance }\end{array}$ & & \begin{tabular}{|l|} 
Moderate \\
Significance
\end{tabular} & & $\begin{array}{l}\text { High } \\
\text { Significance }\end{array}$ \\
\hline & & 0 & 1 & 2 & 3 & 4 & 5 \\
\hline \multirow{2}{*}{10} & \multirow[b]{2}{*}{ Risk } & High Risk & $\begin{array}{l}\text { Moderate } \\
\text { Risk }\end{array}$ & & \begin{tabular}{|l} 
Low Risk \\
\end{tabular} & & $\begin{array}{l}\text { Very Low } \\
\text { Risk }\end{array}$ \\
\hline & & 0 & 1 & 2 & 3 & 4 & 5 \\
\hline \multirow{2}{*}{11} & \multirow{2}{*}{ Altermate uses for biomass } & $\begin{array}{l}\text { NAA or no } \\
\text { Significance }\end{array}$ & \begin{tabular}{|c|} 
Some \\
Significance
\end{tabular} & & \begin{tabular}{|l|} 
Moderate \\
Significance \\
\end{tabular} & & $\begin{array}{c}\text { High } \\
\text { Significance }\end{array}$ \\
\hline & & 0 & 1 & 2 & 3 & 4 & 5 \\
\hline
\end{tabular}

Totals

\section{Comments}

\begin{tabular}{|c|c|c|}
\hline $\begin{array}{c}\text { CTO } \\
\text { Weighting } \\
10\end{array}$ & $\begin{array}{c}\text { Raw } \\
\text { Rating }\end{array}$ & $\begin{array}{c}\text { Weighted } \\
\text { Rating }\end{array}$ \\
\hline $\begin{array}{c}\text { CTO } \\
\text { Weighting }\end{array}$ & $\begin{array}{c}\text { Raw } \\
\text { Rating }\end{array}$ & $\begin{array}{c}\text { Weighted } \\
\text { Rating }\end{array}$ \\
9 & 3 & 27 \\
\hline $\begin{array}{c}\text { CTO } \\
\text { Weighting }\end{array}$ & $\begin{array}{c}\text { Raw } \\
\text { Rating }\end{array}$ & $\begin{array}{c}\text { Weighted } \\
\text { Rating }\end{array}$ \\
8 & 3 & 24 \\
\hline $\begin{array}{c}\text { CTO } \\
\text { Weighting }\end{array}$ & $\begin{array}{c}\text { Raw } \\
\text { Rating }\end{array}$ & $\begin{array}{c}\text { Weighted } \\
\text { Rating }\end{array}$ \\
8 & 5 & 40 \\
\hline $\begin{array}{c}\text { CTO } \\
\text { Weighting }\end{array}$ & $\begin{array}{c}\text { Raw } \\
\text { Rating }\end{array}$ & $\begin{array}{c}\text { Weighted } \\
\text { Rating }\end{array}$ \\
7 & 1 & 7 \\
\hline CTO \\
Weighting & $\begin{array}{c}\text { Raw } \\
\text { Rating }\end{array}$ & $\begin{array}{c}\text { Weighted } \\
\text { Rating }\end{array}$ \\
7 & 4 & 28 \\
\hline $\begin{array}{c}\text { CTO } \\
\text { Weighting }\end{array}$ & $\begin{array}{c}\text { Raw } \\
\text { Rating }\end{array}$ & $\begin{array}{c}\text { Weighted } \\
\text { Rating }\end{array}$ \\
7 & 4 & 28 \\
\hline $\begin{array}{c}\text { CTO } \\
\text { Weighting }\end{array}$ & $\begin{array}{c}\text { Raw } \\
\text { Rating }\end{array}$ & $\begin{array}{c}\text { Weighted } \\
\text { Rating }\end{array}$ \\
7 & 1 & 7 \\
\hline $\begin{array}{c}\text { CTO } \\
\text { Weighting }\end{array}$ & $\begin{array}{c}\text { Raw } \\
\text { Rating }\end{array}$ & $\begin{array}{c}\text { Weighted } \\
\text { Rating }\end{array}$ \\
\hline 6 & 0 & 0 \\
\hline $\begin{array}{c}\text { CTO } \\
\text { Weighting } \\
6\end{array}$ & $\begin{array}{c}\text { Raw } \\
\text { Rating }\end{array}$ & $\begin{array}{c}\text { Weighted } \\
\text { Rating }\end{array}$ \\
\hline $\begin{array}{c}\text { CTO } \\
\text { Weighting }\end{array}$ & $\begin{array}{c}\text { Raw } \\
\text { Rating }\end{array}$ & $\begin{array}{c}\text { Weighted } \\
\text { Rating }\end{array}$ \\
5 & 5 & 25 \\
\hline
\end{tabular}

Not applicable.

There are very many boilers that could use this technology but competing technologies may be able to fill the function without trying something new. This is apparently not a single compelling new technology that trumps all others. Also many locations are not under pressure to deal with NOX and CO simultaneously as this system can do. Increased ability to use biomass and maintain consistent steam supply. Ability to reduce excess air by approximately half, with benefits in reduced electrical load from FD and ID fans resulting in lower volumes of stack gases and lower firebox velocities helping to achieve more stable and efficient combustion.

Low capital cost and ability to retrofit to most stoker boilers have lead to paybacks less than 1 year at Cogentris Power boiler operations. May eliminate the need for future control devices to limit Nox emissions. Installation can recovery energy form waste materials while eliminating the disposal cost of the waste materials.

Very enthusiastic $\mathrm{PI}$. The industry interest is from mild to moderate.

Knowledge of 3-stage combustion process, including design and operational insights

covering how to balance the combustion process across the three stages. Knowledge that non-condensable gases can be use in place in some of the natural gas thereby eliminating the necessity of incineration of these gases.

Lowered Nox with simultaneous control of CO. Potential obviation of the NCG incineration process by use of these gases in the De-Nox process.

Knowledge of combustion process.

Not applicable.

Very low cost and quick payback as well as no extra downtime for installation and ability to revert to previous operational methods make this a very low risk project

Greatly improves the ease of using biomass fuels. BC Int'I Falls tripled their ability to use mill sludge as a fuel. 
FOREST PRODUCTS INDUSTRY OF THE FUTURE - PORTFOLIO STUDY AND EVALUATION

\section{3-993 Gasification Group of Projects}

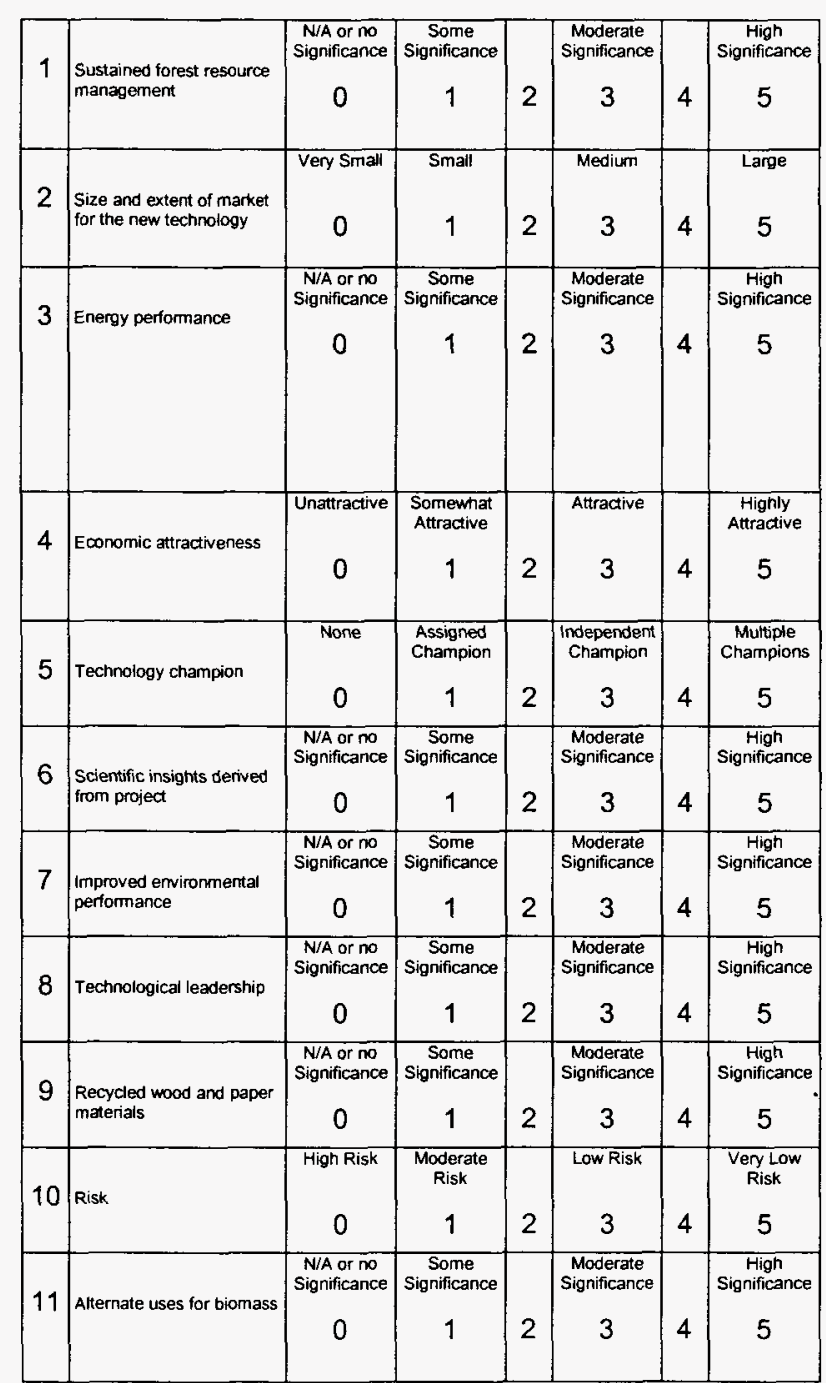

Totals

\begin{tabular}{|c|c|c|}
\hline $\begin{array}{c}\text { CTO } \\
\text { Weighting } \\
10\end{array}$ & $\begin{array}{c}\text { Raw } \\
\text { Rating } \\
2\end{array}$ & $\begin{array}{c}\text { Weighted } \\
\text { Rating } \\
20\end{array}$ \\
\hline $\begin{array}{c}\text { CTO } \\
\text { Weighting }\end{array}$ & $\begin{array}{c}\text { Raw } \\
\text { Rating }\end{array}$ & $\begin{array}{c}\text { Weighted } \\
\text { Rating }\end{array}$ \\
\hline 9 & 5 & 45 \\
\hline $\begin{array}{c}\text { CTO } \\
\text { Weighting }\end{array}$ & $\begin{array}{c}\text { Raw } \\
\text { Rating }\end{array}$ & $\begin{array}{c}\text { Weighted } \\
\text { Rating }\end{array}$ \\
\hline 8 & 5 & 40 \\
\hline $\begin{array}{c}\text { CTO } \\
\text { Weighting }\end{array}$ & $\begin{array}{c}\text { Raw } \\
\text { Rating }\end{array}$ & $\begin{array}{c}\text { Weighted } \\
\text { Rating }\end{array}$ \\
\hline 8 & 4 & 32 \\
\hline $\begin{array}{c}\text { CTO } \\
\text { Weighting }\end{array}$ & $\begin{array}{c}\text { Raw } \\
\text { Rating }\end{array}$ & $\begin{array}{c}\text { Weighted } \\
\text { Rating }\end{array}$ \\
\hline 7 & 5 & 35 \\
\hline $\begin{array}{c}\text { CTO } \\
\text { Weighting }\end{array}$ & $\begin{array}{c}\text { Raw } \\
\text { Rating }\end{array}$ & $\begin{array}{c}\text { Weighted } \\
\text { Rating }\end{array}$ \\
\hline 7 & 5 & 35 \\
\hline $\begin{array}{c}\text { CTOO } \\
\text { Weighting }\end{array}$ & $\begin{array}{c}\text { Raw } \\
\text { Rating }\end{array}$ & $\begin{array}{c}\text { Weighted } \\
\text { Rating }\end{array}$ \\
\hline 7 & 4 & 28 \\
\hline $\begin{array}{c}\text { CTOO } \\
\text { Weighting }\end{array}$ & $\begin{array}{c}\text { Raw } \\
\text { Rating }\end{array}$ & $\begin{array}{c}\text { Weighted } \\
\text { Rating }\end{array}$ \\
\hline 7 & 5 & 35 \\
\hline $\begin{array}{c}\text { CTOO } \\
\text { Weighting }\end{array}$ & $\begin{array}{c}\text { Raw } \\
\text { Rating }\end{array}$ & $\begin{array}{c}\text { Weighted } \\
\text { Rating }\end{array}$ \\
\hline 6 & 1 & 6 \\
\hline $\begin{array}{c}\text { CTOO } \\
\text { Weighting }\end{array}$ & $\begin{array}{c}\text { Raw } \\
\text { Rating }\end{array}$ & $\begin{array}{c}\text { Weighted } \\
\text { Rating }\end{array}$ \\
\hline 6 & 1 & 6 \\
\hline $\begin{array}{c}\text { CTOO } \\
\text { Weighting }\end{array}$ & $\begin{array}{c}\text { Raw } \\
\text { Rating }\end{array}$ & $\begin{array}{c}\text { Weighted } \\
\text { Rating }\end{array}$ \\
\hline 5 & 5 & 25 \\
\hline
\end{tabular}

The ability to separate and direct pulping liquor into qualitatively different components and use appropriately can result in a $5-10 \%$ yield improvement in the pulping process. This has some significance to the Sustainable Forestry efforts because it lowers the required annual harvest.

There are 13 soda mills and 200 Kraft mills that are candidates for this technology.

Gasification itself also has high potential to move into other industries as well.

Energy consumption for chemical recovery in soda liquor mills will go from a negative to a positive with the production of the gas that can be used for fuel, eliminating the current need for purchased auxiliary fuel. The Kraft liquor process will also have significant positive energy benefits from the fuel gas production. Gasification success in black liquor and biomass combined with combined cycle generation can move the industry from a consumer of electricity to a net producer of electricity generating a net 5-20 gigawatts in excess of consumption.

Although the development of this project is high risk, success demonstration of the process will make the gasification option the preferred chemical and energy recovery method for the industry. The recovery boiler replacement or life extension projects will eventually all go to gasifier installation projects without mandates or government incentives.

Pl indicates there are multiple "champions" for this technology.

Multiple insights will be developed.

Compared to $\mathrm{BL}$ recovery boilers, the gasification units will be superior in the areas of particulate emissions, sulfur emissions, and carbon dioxide emissions.

Replacement of Recovery Boilers in the next two decades will be higher in NA than in other parts of world. Replacement with BLG units will result in lower capital, lower emissions, lower energy and be safer and easier to maintain and operate.

There will be some benefit from the ability to recycle waste products into fuel with the gasification process on biomass. Mill sludge is a potential example.

Although there are significant developmental risks with this project, success in this effort will have major nationally significant benefits for the country and the pulp and paper industry.

Gasification of the lignin into a usable, multipurpose, transportable fuel makes the biomass energy available on a broader scale of uses. E.g. electric power generation with gas turbines or reciprocating engine generators, direct mechanical power from gasifier fuel in turbines or reciprocating engines, waste heat recovery boilers downstream of generating units. 


\section{4-1110 Intermediate Sized Entrained Particles}

\begin{tabular}{|c|c|c|c|c|c|c|c|}
\hline 1 & $\begin{array}{l}\text { Sustained forest resource } \\
\text { management }\end{array}$ & \begin{tabular}{|c} 
N/A or no \\
Significance \\
0
\end{tabular} & \begin{tabular}{|c|} 
Some \\
Significance \\
1
\end{tabular} & 2 & \begin{tabular}{|c|} 
Moderate \\
Significance \\
3 \\
\end{tabular} & 4 & \begin{tabular}{|c|c} 
High \\
Significance \\
5
\end{tabular} \\
\hline 2 & $\begin{array}{l}\text { Size and extent of market } \\
\text { for the new tectrology }\end{array}$ & $\begin{array}{c}\text { very Smail } \\
0\end{array}$ & $\begin{array}{c}\text { Small } \\
1\end{array}$ & 2 & $\begin{array}{c}\text { Medium } \\
3\end{array}$ & 4 & $\begin{array}{c}\text { Large } \\
5\end{array}$ \\
\hline 3 & Enemgy perfomance & \begin{tabular}{|c} 
N/A or no \\
Significance \\
0
\end{tabular} & $\begin{array}{c}\text { Some } \\
\text { Significance } \\
1\end{array}$ & 2 & \begin{tabular}{|c} 
Moderate \\
Significance \\
3 \\
3
\end{tabular} & 4 & $\begin{array}{c}\text { High } \\
\text { Significance } \\
5\end{array}$ \\
\hline 4 & Economic atractiveness & $\begin{array}{c}\text { Unattractive } \\
0\end{array}$ & $\begin{array}{c}\text { Somenhat } \\
\text { Atractive } \\
1\end{array}$ & 2 & $\begin{array}{c}\text { Atracive } \\
3\end{array}$ & 4 & $\begin{array}{c}\text { Highly } \\
\text { Atractive } \\
5\end{array}$ \\
\hline 5 & Technology champion & $\begin{array}{c}\text { None } \\
0\end{array}$ & $\begin{array}{c}\text { Assigned } \\
\text { Crampion } \\
1\end{array}$ & 2 & \begin{tabular}{|c} 
Independent \\
Champion \\
3
\end{tabular} & 4 & $\begin{array}{c}\text { Multiple } \\
\text { Champions } \\
5\end{array}$ \\
\hline 6 & $\begin{array}{l}\text { Scientific insights derived } \\
\text { from project }\end{array}$ & $\begin{array}{c}\text { NA or no } \\
\text { Significance } \\
0\end{array}$ & $\begin{array}{c}\text { Some } \\
\text { significance } \\
1\end{array}$ & 2 & $\begin{array}{c}\text { Moderate } \\
\text { Significance } \\
3\end{array}$ & 4 & $\begin{array}{c}\text { High } \\
\text { Significance } \\
5\end{array}$ \\
\hline 7 & $\begin{array}{l}\text { Improved environmental } \\
\text { periomance }\end{array}$ & $\begin{array}{c}\text { N/A or no } \\
\text { Significance } \\
0\end{array}$ & $\begin{array}{c}\text { Some } \\
\text { Significance } \\
1\end{array}$ & 2 & \begin{tabular}{|c} 
Moderate \\
significance \\
3
\end{tabular} & 4 & \begin{tabular}{|c} 
Hign \\
Significance \\
5 \\
5
\end{tabular} \\
\hline 8 & Technological leadership & $\begin{array}{c}\text { N/A or no } \\
\text { Significance } \\
0\end{array}$ & \begin{tabular}{|c} 
Some \\
Significance \\
1
\end{tabular} & 2 & \begin{tabular}{|c}
$\begin{array}{c}\text { Moderate } \\
\text { Significance } \\
3\end{array}$ \\
\end{tabular} & 4 & $\begin{array}{c}\text { High } \\
\text { Significance } \\
5\end{array}$ \\
\hline 9 & $\begin{array}{l}\text { Recycled wood and paper } \\
\text { materials }\end{array}$ & $\begin{array}{c}\text { N/A or no } \\
\text { Significance } \\
0\end{array}$ & $\begin{array}{c}\text { Some } \\
\text { significance } \\
1\end{array}$ & 2 & \begin{tabular}{|c|} 
Moderate \\
Significance \\
3 \\
3
\end{tabular} & 4 & \begin{tabular}{|c|} 
High \\
Significance \\
5
\end{tabular} \\
\hline 10 & Risk & $\begin{array}{c}\text { High Risk } \\
0\end{array}$ & $\begin{array}{c}\begin{array}{c}\text { Moderate } \\
\text { Risk }\end{array} \\
1\end{array}$ & 2 & $\begin{array}{c}\text { Low Risk } \\
3\end{array}$ & 4 & $\begin{array}{c}\text { Very Low } \\
\text { Risk } \\
5\end{array}$ \\
\hline 11 & Altemate uses for biomass & $\begin{array}{c}\text { N/A or mo } \\
\text { Significance } \\
0\end{array}$ & $\begin{array}{c}\text { Some } \\
\text { significance } \\
1\end{array}$ & 2 & $\begin{array}{c}\text { Moderate } \\
\text { Significance } \\
3\end{array}$ & 4 & $\begin{array}{c}\text { High } \\
\text { Significance } \\
5\end{array}$ \\
\hline
\end{tabular}

Totals

\section{Comments}

\begin{tabular}{|c|c|c|}
\hline \begin{tabular}{c|} 
CTO \\
Weighting
\end{tabular} & $\begin{array}{c}\text { Raw } \\
\text { Rating }\end{array}$ & $\begin{array}{c}\text { Weighted } \\
\text { Rating }\end{array}$ \\
\hline 10 & 0 & 0 \\
\hline $\begin{array}{c}\text { CTO } \\
\text { Weighting }\end{array}$ & $\begin{array}{c}\text { Raw } \\
\text { Rating }\end{array}$ & $\begin{array}{c}\text { Weighted } \\
\text { Rating }\end{array}$ \\
\hline 9 & 5 & 45 \\
\hline $\begin{array}{c}\text { CTO } \\
\text { Weighting }\end{array}$ & $\begin{array}{l}\text { Raw } \\
\text { Rating }\end{array}$ & $\begin{array}{c}\text { Weighted } \\
\text { Rating }\end{array}$ \\
\hline 8 & 3 & 24 \\
\hline $\begin{array}{c}\text { CTO } \\
\text { Weighting }\end{array}$ & $\begin{array}{c}\text { Raw } \\
\text { Rating }\end{array}$ & $\begin{array}{c}\text { Weighted } \\
\text { Rating }\end{array}$ \\
\hline 8 & 2 & 16 \\
\hline $\begin{array}{c}\text { CTO } \\
\text { Weighting }\end{array}$ & $\begin{array}{l}\text { Raw } \\
\text { Rating }\end{array}$ & $\begin{array}{c}\text { Weighted } \\
\text { Rating }\end{array}$ \\
\hline 7 & 4 & 28 \\
\hline $\begin{array}{c}\text { CTO } \\
\text { Weighting }\end{array}$ & $\begin{array}{c}\text { Raw } \\
\text { Rating }\end{array}$ & $\begin{array}{c}\text { Weighted } \\
\text { Rating }\end{array}$ \\
\hline 7 & 3 & 21 \\
\hline $\begin{array}{c}\text { Cro } \\
\text { Weighting }\end{array}$ & $\begin{array}{l}\text { Raw } \\
\text { Rating }\end{array}$ & $\begin{array}{l}\text { Weighted } \\
\text { Rating }\end{array}$ \\
\hline 7 & 3 & 21 \\
\hline $\begin{array}{c}\text { CTO } \\
\text { Weighting }\end{array}$ & $\begin{array}{l}\text { Raw } \\
\text { Rating }\end{array}$ & $\begin{array}{c}\text { Weighted } \\
\text { Rating }\end{array}$ \\
\hline 7 & 3 & 21 \\
\hline $\begin{array}{c}\text { CTO } \\
\text { Weighting }\end{array}$ & $\begin{array}{c}\text { Raw } \\
\text { Rating }\end{array}$ & $\begin{array}{c}\begin{array}{c}\text { Weighted } \\
\text { Rating }\end{array} \\
\end{array}$ \\
\hline 6 & 0 & 0 \\
\hline $\begin{array}{c}\text { CTO } \\
\text { Weighting }\end{array}$ & $\begin{array}{l}\text { Raw } \\
\text { Rating }\end{array}$ & $\begin{array}{c}\text { Weighted } \\
\text { Rating }\end{array}$ \\
\hline 6 & 3 & 18 \\
\hline $\begin{array}{c}\text { CTO } \\
\text { Weighting }\end{array}$ & $\begin{array}{l}\text { Raw } \\
\text { Rating }\end{array}$ & $\begin{array}{c}\text { Weighted } \\
\text { Rating }\end{array}$ \\
\hline 5 & 0 & 0 \\
\hline
\end{tabular}

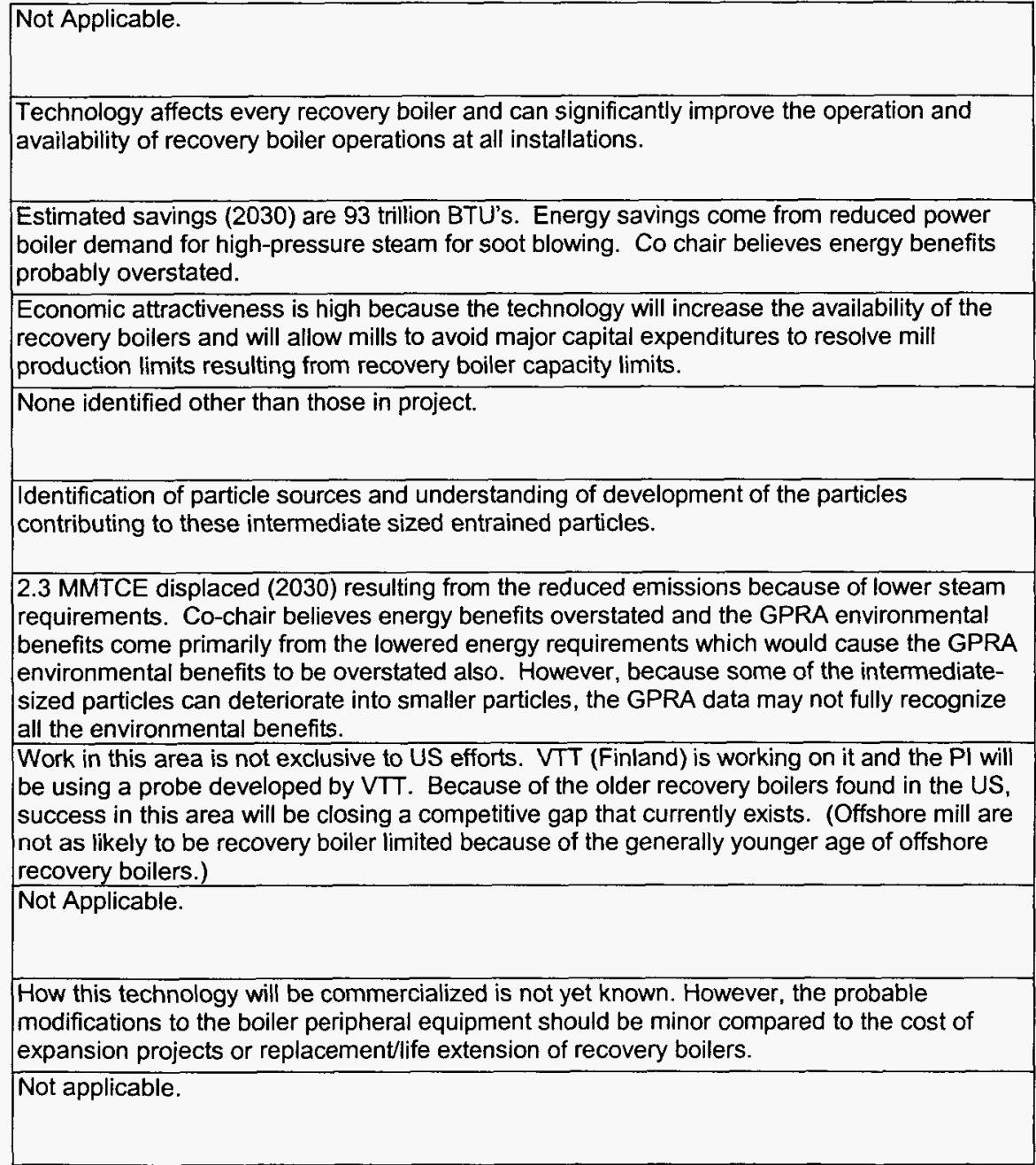

26

194 
05-1166 3-D Characterization of Structure

\begin{tabular}{|c|c|c|c|c|c|c|c|}
\hline \multirow{2}{*}{1} & \multirow{2}{*}{$\begin{array}{l}\text { Sustained forest resource } \\
\text { management }\end{array}$} & $\begin{array}{l}\text { N/A or no } \\
\text { Significance }\end{array}$ & $\begin{array}{l}\text { Some } \\
\text { Significance }\end{array}$ & & \begin{tabular}{|l|} 
Moderate \\
Significance
\end{tabular} & & $\begin{array}{l}\text { High } \\
\text { Significance }\end{array}$ \\
\hline & & 0 & 1 & 2 & 3 & 4 & 5 \\
\hline \multirow{2}{*}{2} & \multirow[b]{2}{*}{$\begin{array}{l}\text { Size and extent of market } \\
\text { for the new technotogy }\end{array}$} & \begin{tabular}{|l|l} 
Very Small \\
\end{tabular} & Small & & Medium & & Large \\
\hline & & 0 & 1 & 2 & 3 & 4 & 5 \\
\hline \multirow{2}{*}{3} & \multirow{2}{*}{ Energy performance } & $\begin{array}{l}\text { N/A or no } \\
\text { Signticance }\end{array}$ & $\begin{array}{l}\text { Some } \\
\text { Significance }\end{array}$ & & \begin{tabular}{|l} 
Moderate \\
Significance
\end{tabular} & & $\begin{array}{l}\text { High } \\
\text { Significance } \\
\end{array}$ \\
\hline & & 0 & 1 & 2 & 3 & 4 & 5 \\
\hline \multirow{2}{*}{4} & \multirow{2}{*}{ Economic attractiveness } & \begin{tabular}{|l} 
Unatractive \\
\end{tabular} & $\begin{array}{l}\text { Somewhat } \\
\text { Atractive }\end{array}$ & & Attracive & & \begin{tabular}{|l} 
Highly \\
Atractive
\end{tabular} \\
\hline & & 0 & 1 & 2 & 3 & 4 & 5 \\
\hline \multirow{2}{*}{5} & \multirow{2}{*}{ Technology champion } & None & \begin{tabular}{|l|} 
Assigned \\
Champion
\end{tabular} & & \begin{tabular}{|c|} 
Independent \\
Champion
\end{tabular} & & \begin{tabular}{|c|} 
Multiphe \\
Champlons
\end{tabular} \\
\hline & & 0 & 1 & 2 & 3 & 4 & 5 \\
\hline \multirow{2}{*}{6} & \multirow{2}{*}{$\begin{array}{l}\text { Scientific insights derived } \\
\text { from project }\end{array}$} & $\begin{array}{l}\text { N/A or no } \\
\text { Significance }\end{array}$ & $\begin{array}{l}\text { Some } \\
\text { Significance }\end{array}$ & & \begin{tabular}{|l|} 
Moderate \\
Significance
\end{tabular} & & $\begin{array}{l}\text { High } \\
\text { Significance }\end{array}$ \\
\hline & & 0 & 1 & 2 & 3 & 4 & 5 \\
\hline \multirow{2}{*}{7} & \multirow{2}{*}{$\begin{array}{l}\text { Improved environmental } \\
\text { performance }\end{array}$} & $\begin{array}{l}\text { N/A or no } \\
\text { Significance }\end{array}$ & $\begin{array}{l}\text { Some } \\
\text { Significance }\end{array}$ & & \begin{tabular}{|l} 
Moderate \\
Significance
\end{tabular} & & $\begin{array}{l}\text { High } \\
\text { Significance }\end{array}$ \\
\hline & & 0 & 1 & 2 & 3 & 4 & 5 \\
\hline \multirow{2}{*}{8} & \multirow{2}{*}{ Technological leadership } & \begin{tabular}{|l} 
N/A or no \\
Significance
\end{tabular} & $\begin{array}{l}\text { Some } \\
\text { Signiticance }\end{array}$ & & \begin{tabular}{|l} 
Moderate \\
Significancoe
\end{tabular} & & \begin{tabular}{|l} 
High \\
Significance \\
\end{tabular} \\
\hline & & 0 & 1 & 2 & 3 & 4 & 5 \\
\hline \multirow{2}{*}{9} & \multirow{2}{*}{$\begin{array}{l}\begin{array}{l}\text { Recycled wood and paper } \\
\text { materials }\end{array} \\
\end{array}$} & \begin{tabular}{|l} 
N/A o n n \\
Significance
\end{tabular} & $\begin{array}{l}\text { Some } \\
\text { Significance }\end{array}$ & & \begin{tabular}{|l|} 
Moderate \\
Significance
\end{tabular} & & $\begin{array}{l}\text { High } \\
\text { Significance } \\
\end{array}$ \\
\hline & & 0 & 1 & 2 & 3 & 4 & 5 \\
\hline \multirow{2}{*}{10} & \multirow{2}{*}{ Risk } & High Risk & $\begin{array}{l}\text { Moderate } \\
\text { Risk }\end{array}$ & & \begin{tabular}{|l|} 
Low Risk \\
\end{tabular} & & $\begin{array}{l}\text { Very Low } \\
\text { Risk }\end{array}$ \\
\hline & & 0 & 1 & 2 & 3 & 4 & 5 \\
\hline \multirow{2}{*}{11} & \multirow{2}{*}{ Antermate uses for biomass } & \begin{tabular}{|l} 
N/A or no \\
Significance
\end{tabular} & $\begin{array}{l}\text { Some } \\
\text { Significance }\end{array}$ & & \begin{tabular}{|l|} 
Moderate \\
Significance
\end{tabular} & & $\begin{array}{l}\text { High } \\
\text { Significance }\end{array}$ \\
\hline & & 0 & 1 & 2 & 3 & 4 & 5 \\
\hline
\end{tabular}

Totals

\begin{tabular}{|c|c|c|}
\hline $\begin{array}{l}\text { cro } \\
\text { Weighti }\end{array}$ & $\begin{array}{l}\text { Raw } \\
\text { ating }\end{array}$ & ting \\
\hline 10 & 1 & 10 \\
\hline $\begin{array}{l}\text { CTO } \\
\text { eighting }\end{array}$ & $\begin{array}{l}\text { Raw } \\
\text { Rating }\end{array}$ & \\
\hline 9 & 4 & 36 \\
\hline $\begin{array}{l}\text { cro } \\
\text { eighting }\end{array}$ & $\begin{array}{l}\text { Raw } \\
\text { Rating }\end{array}$ & $\begin{array}{l}\text { Neighted } \\
\text { Rating }\end{array}$ \\
\hline 0 & & 24 \\
\hline $\begin{array}{l}\text { CTO } \\
\text { elighting }\end{array}$ & $\begin{array}{l}\text { Raw } \\
\text { Rating }\end{array}$ & $\begin{array}{l}\text { Ratiting } \\
\text { Rate }\end{array}$ \\
\hline 8 & 3 & \\
\hline $\begin{array}{l}\text { cro } \\
\text { eighting }\end{array}$ & $\begin{array}{l}\text { Raw } \\
\text { Rating }\end{array}$ & $\begin{array}{l}\text { Weighted } \\
\text { Rating }\end{array}$ \\
\hline & & \\
\hline $\begin{array}{l}\text { cro } \\
\text { eighting }\end{array}$ & $\begin{array}{l}\text { Raw } \\
\text { Rating }\end{array}$ & $\begin{array}{l}\text { Weight } \\
\text { Rating }\end{array}$ \\
\hline 7 & 5 & 35 \\
\hline $\begin{array}{l}\text { cro- } \\
\text { eighting }\end{array}$ & $\begin{array}{l}\text { Raw } \\
\text { Rating }\end{array}$ & Ratin \\
\hline 7 & 1 & \\
\hline $\begin{array}{l}\text { cro } \\
\text { veighting }\end{array}$ & $\begin{array}{l}\text { Raw } \\
\text { Rating }\end{array}$ & \\
\hline & & \\
\hline $\begin{array}{l}\text { CTO } \\
\text { Weighting }\end{array}$ & $\begin{array}{l}\text { Raw } \\
\text { Rating }\end{array}$ & Rating \\
\hline 0 & & \\
\hline $\begin{array}{l}\text { CTO } \\
\text { Weighting }\end{array}$ & $\begin{array}{l}\text { Raw } \\
\text { Rating }\end{array}$ & Ratin \\
\hline 6 & & \\
\hline $\begin{array}{l}\text { CTO } \\
\text { elighting }\end{array}$ & $\begin{array}{l}\text { Raw } \\
\text { Rating }\end{array}$ & Ratin \\
\hline 5 & & \\
\hline
\end{tabular}

Optimizing the fiber in the refining processes can significant fiber in the tissue and towe production.

All paper production is a market for the knowledge to be developed in this project. Devices that might be developed to routinely investigate the internal structure have a more limited market.

Success characterizing the structure and in subsequent research on ways to make paper that releases water more rapidly will provide substantial energy benefits but this "enabling technology" itself is of minor energy significance.

Interest in knowledge to be developed is widespread but tempered by the realization of the difficulty of translating the knowledge into practical process that will materially affect paper production methods.

Knowledge of the internal structure will allow correlation of structural properties with observable and measurable properties of the paper. That knowledge will enable work into identifying and controlling variables that alter the structure.

Indirect connection to possible changes in pulp and paper processes could reduce environmental impacts by lowering energy requirement or perhaps water requirements.

This technique will be an enabling technology to allow efforts in "designing" desirable physical properties into the sheet and developing methods to manufacture sheets meeting the desired design specifications.

Ability to determine differences in recycled product from the structure of non-recycled product is very significant.

This is a speculative investment in research. Low risk that the internal structure can be

examined, but riskier than it can be meaningfully quantified and that correlation with process variables can be identified.

Not applicable. 
FOREST PRODUCTS INDUSTRY OF THE FUTURE - PORTFOLIO STUDY AND EVALUATION

\section{6-669 High Efficiency $\mathrm{ClO}_{2}$ Delignification}

\begin{tabular}{|c|c|c|c|c|c|c|c|}
\hline 1 & \begin{tabular}{|l|} 
Sustained forest resource \\
management
\end{tabular} & $\begin{array}{c}\text { N/A or no } \\
\text { Significance } \\
0\end{array}$ & \begin{tabular}{|c} 
Some \\
Significance \\
1
\end{tabular} & 2 & $\mid \begin{array}{c}\text { Moderate } \\
\text { Significance } \\
3\end{array}$ & 4 & $\begin{array}{c}\text { High } \\
\text { Significance } \\
5\end{array}$ \\
\hline 2 & $\begin{array}{l}\text { Size and extem of market } \\
\text { for the new technology }\end{array}$ & \begin{tabular}{|c|} 
Very Small \\
0
\end{tabular} & $\begin{array}{c}\text { Small } \\
1\end{array}$ & 2 & $\begin{array}{c}\text { Medium } \\
3\end{array}$ & 4 & $\begin{array}{l}\text { Large } \\
5\end{array}$ \\
\hline 3 & Energy performance & \begin{tabular}{|c|} 
N/A or no \\
Significance \\
0 \\
0
\end{tabular} & \begin{tabular}{|c|} 
Some \\
significance \\
1
\end{tabular} & 2 & \begin{tabular}{|c|} 
Moderate \\
Significance \\
3
\end{tabular} & 4 & \begin{tabular}{|c|} 
High \\
Significance \\
5 \\
5
\end{tabular} \\
\hline 4 & Economic attractiveness & \begin{tabular}{|c|} 
Unattractive \\
0
\end{tabular} & \begin{tabular}{|c|}
$\begin{array}{c}\text { Somewhat } \\
\text { Atractive } \\
1\end{array}$ \\
\end{tabular} & 2 & $\begin{array}{c}\text { Atraative } \\
3 \\
\end{array}$ & 4 & $\begin{array}{c}\text { Highly } \\
\text { Atrative } \\
5 \\
5\end{array}$ \\
\hline 5 & Technology champion & $\begin{array}{c}\text { None } \\
0\end{array}$ & \begin{tabular}{|c|} 
Assigned \\
Champion \\
1 \\
\end{tabular} & 2 & \begin{tabular}{|c|} 
independent \\
Champion \\
3 \\
\end{tabular} & 4 & \begin{tabular}{|c} 
Multiple \\
Champions \\
5
\end{tabular} \\
\hline 6 & $\begin{array}{l}\text { Scientific insights derived } \\
\text { from project }\end{array}$ & \begin{tabular}{|c|} 
N/A or no \\
Significance \\
0 \\
0
\end{tabular} & \begin{tabular}{|c|} 
Some \\
Significance \\
1
\end{tabular} & 2 & \begin{tabular}{|c|} 
Moderate \\
Significance \\
3 \\
\end{tabular} & 4 & \begin{tabular}{|c} 
High \\
Significance \\
5 \\
5
\end{tabular} \\
\hline 7 & $\begin{array}{l}\text { Improved environmental } \\
\text { performance }\end{array}$ & \begin{tabular}{|c|} 
N/A or no \\
Significance \\
0 \\
\end{tabular} & \begin{tabular}{|c|} 
Some \\
Significance \\
1
\end{tabular} & 2 & \begin{tabular}{|c|} 
Moderate \\
Significance \\
3 \\
\end{tabular} & 4 & \begin{tabular}{|c|}
$\begin{array}{c}\text { High } \\
\text { Significance } \\
\\
5\end{array}$ \\
\end{tabular} \\
\hline 8 & Technological leadership & \begin{tabular}{|c|}
$\begin{array}{c}\text { N/A or no } \\
\text { Significance } \\
0\end{array}$ \\
\end{tabular} & \begin{tabular}{|c|} 
Some \\
Significance \\
1 \\
\end{tabular} & 2 & \begin{tabular}{|c|} 
Moderate \\
Significance \\
3 \\
\end{tabular} & 4 & \begin{tabular}{|c} 
High \\
Significance \\
5 \\
5
\end{tabular} \\
\hline 9 & $\begin{array}{l}\text { Recycled wood and paper } \\
\text { materials }\end{array}$ & \begin{tabular}{|c|} 
N/A or no \\
Signnificance \\
0 \\
\end{tabular} & \begin{tabular}{|c|} 
Some \\
Significance \\
1 \\
\end{tabular} & 2 & \begin{tabular}{|c|} 
Moderale \\
Significance \\
3 \\
\end{tabular} & 4 & \begin{tabular}{|c|} 
High \\
Significance \\
5 \\
5
\end{tabular} \\
\hline 10 & Risk & $\begin{array}{c}\text { High Risk } \\
0\end{array}$ & $\begin{array}{c}\begin{array}{c}\text { Moderate } \\
\text { Risk } \\
1\end{array} \\
1\end{array}$ & 2 & \begin{tabular}{|c} 
Low Risk \\
3 \\
3
\end{tabular} & 4 & 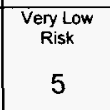 \\
\hline 11 & Afternate uses for biomass & \begin{tabular}{|c|}
$\begin{array}{c}\text { N/A or no } \\
\text { Significance } \\
0 \\
0\end{array}$ \\
\end{tabular} & \begin{tabular}{|c|} 
Some \\
Significance \\
1 \\
1
\end{tabular} & 2 & \begin{tabular}{|c|} 
Moderate \\
Significance \\
3 \\
\end{tabular} & 4 & $\begin{array}{c}\text { High } \\
\text { Significance } \\
5 \\
5\end{array}$ \\
\hline
\end{tabular}

Totals

\begin{tabular}{|c|c|c|}
\hline \begin{tabular}{c|} 
CTO \\
Weighting
\end{tabular} & $\begin{array}{c}\text { Raw } \\
\text { Rating }\end{array}$ & \begin{tabular}{|c|} 
Weighted \\
Rating
\end{tabular} \\
\hline 10 & 0 & 0 \\
\hline \begin{tabular}{c|c|} 
CTO \\
Weighting
\end{tabular} & $\begin{array}{c}\text { Raw } \\
\text { Rating }\end{array}$ & \begin{tabular}{|c|} 
Weighted \\
Rating
\end{tabular} \\
\hline 9 & 5 & 45 \\
\hline $\begin{array}{c}\text { CTO } \\
\text { Weighting }\end{array}$ & $\begin{array}{c}\text { Raw } \\
\text { Rating }\end{array}$ & \begin{tabular}{|c|} 
Weighted \\
Rating
\end{tabular} \\
\hline 8 & 2 & 16 \\
\hline $\begin{array}{c}\text { Cró } \\
\text { Weighting }\end{array}$ & $\begin{array}{c}\text { Raw } \\
\text { Rating }\end{array}$ & \begin{tabular}{|c|} 
Weighted \\
Rating
\end{tabular} \\
\hline 8 & 4 & 32 \\
\hline $\begin{array}{c}\text { Cro } \\
\text { Weighting }\end{array}$ & $\begin{array}{c}\text { Raw } \\
\text { Rating }\end{array}$ & \begin{tabular}{|c|} 
Weighted \\
Rating
\end{tabular} \\
\hline 7 & 2 & 1. \\
\hline $\begin{array}{c}\text { CTO } \\
\text { Weighting }\end{array}$ & $\begin{array}{c}\text { Raw } \\
\text { Rating }\end{array}$ & \begin{tabular}{|c|} 
Weighted \\
Rating
\end{tabular} \\
\hline 7 & 5 & 3 \\
\hline $\begin{array}{c}\text { CTO } \\
\text { Weighting }\end{array}$ & $\begin{array}{c}\text { Raw } \\
\text { Rating }\end{array}$ & \begin{tabular}{|c|} 
Weighted \\
Rating
\end{tabular} \\
\hline 7 & 2 & 8 \\
\hline $\begin{array}{c}\text { CTO } \\
\text { Weighting }\end{array}$ & $\begin{array}{c}\text { Raw } \\
\text { Rating }\end{array}$ & $\begin{array}{c}\text { Weighted } \\
\text { Rating }\end{array}$ \\
\hline$\gamma$ & 3 & 21 \\
\hline $\begin{array}{c}\text { CTO } \\
\text { Weighting }\end{array}$ & $\begin{array}{l}\text { Raw } \\
\text { Rating }\end{array}$ & $\begin{array}{c}\text { Weighted } \\
\text { Rating }\end{array}$ \\
\hline 0 & 2 & 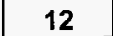 \\
\hline $\begin{array}{c}\text { CTO } \\
\text { Weighting }\end{array}$ & $\begin{array}{c}\text { Raw } \\
\text { Rating }\end{array}$ & $\begin{array}{c}\text { Weighted } \\
\text { Rating }\end{array}$ \\
\hline 6 & 7 & 24 \\
\hline $\begin{array}{c}\text { CTO } \\
\text { Weighting }\end{array}$ & $\begin{array}{c}\text { Raw } \\
\text { Rating }\end{array}$ & $\begin{array}{c}\text { Weighted } \\
\text { Rating }\end{array}$ \\
\hline כ & 0 & 0 \\
\hline
\end{tabular}

Not applicable.

This research is highly important to the bleached Kraft paper business.

Limited energy benefits, deriving from shorter bleach stage cycles and indirectly from reduced demand for and, consequently, lower production of $\mathrm{ClO}_{2}$.

Very attractive to mills that are adding bleaching capacity. PI (McDonough) believes a rapid $D_{0}$ stage might cost only $\$ 1-2$ Million as compared to $\$ 30-45$ million for alternatives.

PI considers himself a long time champion for this technology. He has engaged in dialog with two different companies about projects to incorporate the technology.

Understanding, at the molecular level, of the fundamental mechanisms of $\mathrm{ClO}_{2}$ delignification and interactions of phenolic hydroxyls, beta-o-aryl ethers and hexenuronic acids.

Research will lead to lower usage of $\mathrm{ClO}_{2}$ and consequently lower formation of $\mathrm{AOX}$.

Research team confirmed earlier Scandinavian research on hexenuronic acids.

Some significance to recycling of OCC which can be upgraded by bleaching.

Research project was successful. Commercialization of rapid $D_{0}$ stage poses little risk.

There could be unknowns that might be uncovered in a scale-up effort but they are thought to be small.

Not applicable. 


\section{FOREST PRODUCTS INDUSTRY OF THE FUTURE - PORTFOLIO STUDY AND EVALUATION}

\section{7-685 VOC Control in Kraft Mills}

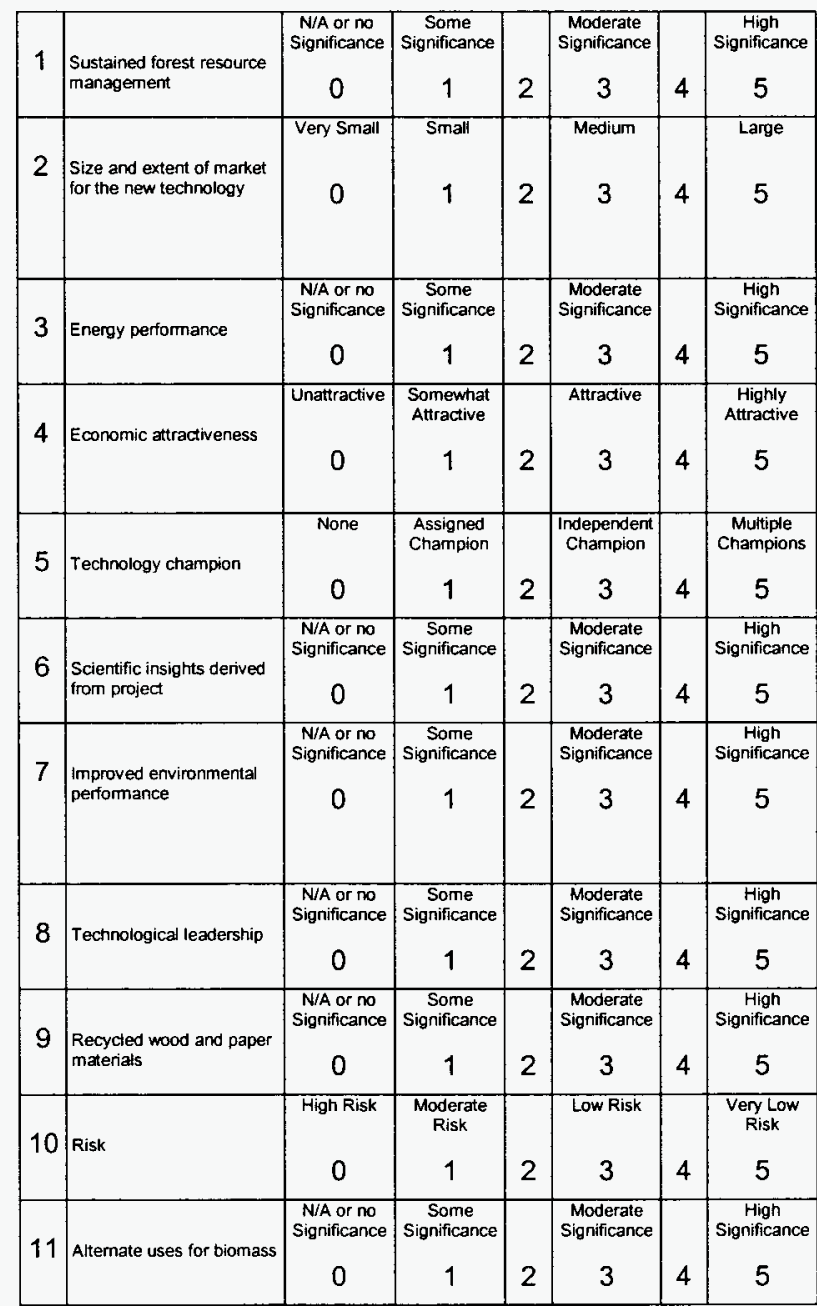

Totals

\begin{tabular}{|c|c|c|}
\hline \begin{tabular}{c|c} 
CTO \\
Weighting
\end{tabular} & $\begin{array}{l}\text { Raw } \\
\text { Rating }\end{array}$ & $\begin{array}{c}\text { Weighted } \\
\text { Rating }\end{array}$ \\
\hline 10 & 0 & 0 \\
\hline \begin{tabular}{|c|} 
CTO \\
Weighting
\end{tabular} & $\begin{array}{l}\text { Raw } \\
\text { Rating }\end{array}$ & $\begin{array}{c}\text { Weighted } \\
\text { Rating }\end{array}$ \\
\hline 9 & 3 & 27 \\
\hline \begin{tabular}{|c|} 
CTO \\
Weighting
\end{tabular} & $\begin{array}{l}\text { Raw } \\
\text { Rating }\end{array}$ & \begin{tabular}{c|}
$\begin{array}{c}\text { Weighted } \\
\text { Rating }\end{array}$ \\
\end{tabular} \\
\hline 8 & 2 & 16 \\
\hline \begin{tabular}{|c|} 
Cró \\
Weighting
\end{tabular} & $\begin{array}{l}\text { Raw } \\
\text { Rating }\end{array}$ & $\begin{array}{c}\text { Weighted } \\
\text { Rating }\end{array}$ \\
\hline 8 & 1 & 8 \\
\hline \begin{tabular}{|c|} 
CTO \\
Weighting
\end{tabular} & $\begin{array}{l}\text { Raw } \\
\text { Rating }\end{array}$ & $\begin{array}{c}\text { Weighted } \\
\text { Rating }\end{array}$ \\
\hline 7 & 0 & 0 \\
\hline \begin{tabular}{|c|} 
CTO \\
Weighting
\end{tabular} & $\begin{array}{l}\text { Raw } \\
\text { Rating }\end{array}$ & \begin{tabular}{|c|} 
Weighted \\
Rating
\end{tabular} \\
\hline 7 & 4 & 2 \\
\hline \begin{tabular}{|c|} 
CTO \\
weighting
\end{tabular} & $\begin{array}{l}\text { Raw } \\
\text { Rating }\end{array}$ & \begin{tabular}{|c|} 
Weighted \\
Rating
\end{tabular} \\
\hline 7 & 3 & 21 \\
\hline $\begin{array}{c}\text { Cro } \\
\text { Weighting }\end{array}$ & $\begin{array}{c}\text { Raw } \\
\text { Rating }\end{array}$ & $\begin{array}{c}\text { Weighted } \\
\text { Rating }\end{array}$ \\
\hline 7 & 4 & \\
\hline $\begin{array}{c}\text { CTO } \\
\text { Weighting }\end{array}$ & $\begin{array}{l}\text { Raw } \\
\text { Rating }\end{array}$ & $\begin{array}{c}\text { Weighted } \\
\text { Rating }\end{array}$ \\
\hline 6 & 0 & \\
\hline \begin{tabular}{|c|} 
CTO \\
Weighting
\end{tabular} & $\begin{array}{l}\text { Raw } \\
\text { Rating }\end{array}$ & \begin{tabular}{|c|} 
Weighted \\
Rating
\end{tabular} \\
\hline 6 & 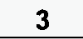 & 18 \\
\hline \begin{tabular}{|c|} 
CTO \\
Weighting
\end{tabular} & $\begin{array}{l}\text { Raw } \\
\text { Rating }\end{array}$ & \begin{tabular}{|c|} 
Weighted \\
Rating
\end{tabular} \\
\hline & & \\
\hline
\end{tabular}

If commercialized, the, membrane technology could be widely applied to VOC/HAP problems. The technology works on methanol, the predominant component of the gas phase in the pulp and paper emissions, as well as on the other, higher molecular weight VOC/HAP emissions. Large potential market limited by cost. PI of membrane research doesn't think it will go anywhere unless something else forces it.

Paper companies are under mandates to control VOC and this technology, while beneficial to identifying the sources, will be most useful in sizing control devices rather than directly contributing to the amelioration of the problem.

The use of the software in the model is attractive and is currently being used. The use of membrane technology to remove methanol is unattractive. The economics are location dependent but in most cases the value of methanol recovered does not warrant a switch to this technology. None identified.

Development and validation of the model to predict the generation of VOC

GPRA numbers for environmental benefit seem low for a project that ultimately could be used in the control of most of VOC/HAPs from the pulp and paper process. However,

manufacturers are already under regulatory requirements to control these emissions and are doing so with other technologies. Consequently, the net environmental benefit is not as great as might be initially imagined.

Development of the VOC/HAP emission model software.

Not applicable.

Model development successful. Use of the model can be a way to reduce risk by developing control measure design specifications that are properly designed and sized for the VOCs being controlled. Risk in the use of the membrane separation technology is a moot question. The analytic methods developed in this project would be applicable to modeling emissions from other processes that might be used on biomass. 
08-687 Low VOC Drying of Lumber and Wood

\begin{tabular}{|c|c|c|c|c|c|c|c|}
\hline 1 & \begin{tabular}{|l|} 
Sustained forest resource \\
management
\end{tabular} & \begin{tabular}{|c|} 
N/A or no \\
Significance \\
0
\end{tabular} & \begin{tabular}{|c|} 
Some \\
Significance \\
1 \\
\end{tabular} & 2 & \begin{tabular}{|c|} 
Moderate \\
Significance \\
3 \\
\end{tabular} & 4 & \begin{tabular}{|c|} 
High \\
Significance \\
5 \\
5
\end{tabular} \\
\hline 2 & $\begin{array}{l}\text { Size and extent of market } \\
\text { for the new technology }\end{array}$ & \begin{tabular}{|c} 
Very Small \\
0
\end{tabular} & $\begin{array}{c}\text { Small } \\
1\end{array}$ & 2 & $\begin{array}{c}\text { Medium } \\
3 \\
3\end{array}$ & 4 & $\begin{array}{l}\text { Large } \\
5 \\
5\end{array}$ \\
\hline 3 & Energy performance & \begin{tabular}{|c} 
N/A or no \\
Significance \\
0
\end{tabular} & \begin{tabular}{|c|} 
Some \\
Significance \\
1
\end{tabular} & 2 & \begin{tabular}{|c|} 
Moderate \\
Significance \\
3 \\
\end{tabular} & 4 & \begin{tabular}{|c} 
High \\
Significance \\
5 \\
5
\end{tabular} \\
\hline 4 & Economic attractiveness & $\begin{array}{c}\text { Unattractive } \\
0\end{array}$ & $\begin{array}{c}\text { Somewhat } \\
\text { Attractive } \\
1\end{array}$ & 2 & $\begin{array}{c}\text { Attractive } \\
3\end{array}$ & 4 & $\begin{array}{c}\begin{array}{c}\text { Highly } \\
\text { Atractive }\end{array} \\
5\end{array}$ \\
\hline 5 & Techrology champion & $\begin{array}{l}\text { None } \\
0\end{array}$ & \begin{tabular}{|c|} 
Assigned \\
Champion \\
1 \\
\end{tabular} & 2 & \begin{tabular}{|c|}
$\begin{array}{c}\text { Independent } \\
\text { Champion }\end{array}$ \\
$\mathbf{3}$
\end{tabular} & 4 & $\begin{array}{c}\text { Muttiple } \\
\text { Champions } \\
5\end{array}$ \\
\hline 6 & $\begin{array}{l}\text { Scientifici insights denved } \\
\text { from project }\end{array}$ & $\begin{array}{c}\text { N/A or no } \\
\text { Significance } \\
0 \\
0\end{array}$ & \begin{tabular}{|c|} 
Some \\
Significance \\
1
\end{tabular} & 2 & \begin{tabular}{|c|} 
Moderate \\
Significance \\
$\mathbf{3}$ \\
\end{tabular} & 4 & $\begin{array}{c}\text { High } \\
\text { Significance } \\
5\end{array}$ \\
\hline 7 & $\begin{array}{l}\text { Improved environmental } \\
\text { performance }\end{array}$ & \begin{tabular}{|c} 
N/A or no \\
Significance \\
0
\end{tabular} & \begin{tabular}{|c|} 
Some \\
Significance \\
1
\end{tabular} & 2 & \begin{tabular}{|c|} 
Moderate \\
Significance \\
3 \\
\end{tabular} & 4 & \begin{tabular}{|c} 
High \\
Significance \\
5 \\
5
\end{tabular} \\
\hline 8 & Technological leadership & $\begin{array}{c}\text { N/A or no } \\
\text { Significance } \\
0 \\
0\end{array}$ & \begin{tabular}{|c|} 
Some \\
Significance \\
1
\end{tabular} & 2 & \begin{tabular}{|c|} 
Moderate \\
Signnificance \\
3 \\
\end{tabular} & 4 & $\begin{array}{c}\text { High } \\
\text { Significance } \\
5 \\
5\end{array}$ \\
\hline 9 & $\begin{array}{l}\text { Recycled wood and paper } \\
\text { materials }\end{array}$ & $\begin{array}{c}\text { N/A or no } \\
\text { Significance } \\
0\end{array}$ & \begin{tabular}{|c|} 
Some \\
significance \\
1
\end{tabular} & 2 & \begin{tabular}{|c|} 
Moderate \\
Significance \\
3 \\
\end{tabular} & 4 & $\begin{array}{c}\text { High } \\
\text { Significance } \\
5\end{array}$ \\
\hline 10 & Risk & $\begin{array}{c}\text { High Risk } \\
0\end{array}$ & $\begin{array}{c}\begin{array}{c}\text { Moderate } \\
\text { Risk }\end{array} \\
1\end{array}$ & 2 & $\begin{array}{c}\text { Low Risk } \\
3\end{array}$ & 4 & 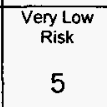 \\
\hline 11 & Attemate uses for biomass & \begin{tabular}{|c} 
N/A or no \\
Significance \\
0
\end{tabular} & $\begin{array}{c}\text { Some } \\
\text { significance } \\
1\end{array}$ & 2 & \begin{tabular}{|c|} 
Moderate \\
Significance \\
3 \\
3
\end{tabular} & 4 & \begin{tabular}{|c} 
High \\
Significance \\
5 \\
5
\end{tabular} \\
\hline
\end{tabular}

Totals

\section{Comments}

\begin{tabular}{|c|c|c|}
\hline $\begin{array}{c}\text { CTO } \\
\text { Weighting }\end{array}$ & $\begin{array}{l}\text { Raw } \\
\text { Rating }\end{array}$ & $\begin{array}{c}\text { Weighted } \\
\text { Rating }\end{array}$ \\
\hline 10 & 0 & $\mathbf{0}$ \\
\hline $\begin{array}{c}\text { CTO } \\
\text { Weighting }\end{array}$ & $\begin{array}{c}\text { Raw } \\
\text { Rating }\end{array}$ & $\begin{array}{c}\text { Weighted } \\
\text { Rating }\end{array}$ \\
\hline 9 & 5 & 45 \\
\hline $\begin{array}{c}\text { CTO } \\
\text { Weighting }\end{array}$ & $\begin{array}{c}\text { Raw } \\
\text { Rating }\end{array}$ & $\begin{array}{c}\text { Weighted } \\
\text { Rating }\end{array}$ \\
\hline 8 & 1 & 8 \\
\hline $\begin{array}{c}\text { CTO } \\
\text { Weighting }\end{array}$ & $\begin{array}{l}\text { Raw } \\
\text { Rating }\end{array}$ & $\begin{array}{c}\text { Weighted } \\
\text { Rating }\end{array}$ \\
\hline 8 & 3 & 24 \\
\hline $\begin{array}{c}\text { CTO } \\
\text { Weighting }\end{array}$ & $\begin{array}{c}\text { Raw } \\
\text { Rating }\end{array}$ & $\begin{array}{c}\text { Weighted } \\
\text { Rating }\end{array}$ \\
\hline 7 & 3 & 21 \\
\hline $\begin{array}{c}\text { CTO } \\
\text { Weighting }\end{array}$ & $\begin{array}{c}\text { Raw } \\
\text { Rating }\end{array}$ & $\begin{array}{c}\text { Weighted } \\
\text { Rating }\end{array}$ \\
\hline 7 & 5 & 35 \\
\hline $\begin{array}{c}\text { CTO } \\
\text { Weighting }\end{array}$ & $\begin{array}{l}\text { Raw } \\
\text { Rating }\end{array}$ & $\begin{array}{c}\text { Weighted } \\
\text { Rating }\end{array}$ \\
\hline 7 & 5 & 35 \\
\hline $\begin{array}{c}\text { CTO } \\
\text { Weighting }\end{array}$ & $\begin{array}{c}\text { Raw } \\
\text { Rating }\end{array}$ & $\begin{array}{c}\text { Weighted } \\
\text { Rating }\end{array}$ \\
\hline 7 & 1 & 7 \\
\hline $\begin{array}{c}\text { CTO } \\
\text { Weighting }\end{array}$ & $\begin{array}{l}\text { Raw } \\
\text { Rating }\end{array}$ & $\begin{array}{c}\text { Weighted } \\
\text { Rating }\end{array}$ \\
\hline 6 & 0 & 0 \\
\hline $\begin{array}{c}\text { CTO } \\
\text { Weighting }\end{array}$ & $\begin{array}{c}\text { Raw } \\
\text { Rating }\end{array}$ & $\begin{array}{c}\text { Weighted } \\
\text { Rating }\end{array}$ \\
\hline 6 & 3 & 18 \\
\hline $\begin{array}{c}\text { CTO } \\
\text { Weighting }\end{array}$ & $\begin{array}{c}\text { Raw } \\
\text { Rating }\end{array}$ & $\begin{array}{c}\text { Weighted } \\
\text { Rating }\end{array}$ \\
\hline 5 & 0 & 0 \\
\hline
\end{tabular}

\begin{tabular}{|c|}
\hline Not applicable. \\
\hline $\begin{array}{l}\text { VOC control in solid wood product production is a large potential market. Technology for } \\
\text { lumber drying operations has not been commercialized. If successful and economical, this } \\
\text { technology could be widely applied. }\end{array}$ \\
\hline $\begin{array}{l}\text { Use of low-pressure steam will drive off VOCs at lower temperatures in a more concentrated } \\
\text { fashion. Collection or destruction of the VOCs still must be accomplished. }\end{array}$ \\
\hline $\begin{array}{l}\text { Installation of unit in Maine at } 1 / 3 \text { of cost of RTO is an attractive alternative to the } \\
\text { conventional RTO installation and operation of an RTO. }\end{array}$ \\
\hline G-P (Lawrence Otwell) is champion for this project. \\
\hline Timing of emissions during the drying and pressing cycles. \\
\hline Technology will facilitate control of VOCs and HAPs from solid lumber operations. \\
\hline $\begin{array}{l}\text { Since work on lumber application has been discontinued, the application of this technology is } \\
\text { limited to the wood panel industry. Incremental benefits are expected over current } \\
\text { technology although the economics may be better. }\end{array}$ \\
\hline Not applicable. \\
\hline $\begin{array}{l}\text { Low risk to technical success in research. Risk to commercialization depends on economics, } \\
\text { which is thought to be low. }\end{array}$ \\
\hline Not applicable. \\
\hline
\end{tabular}

\begin{tabular}{|l|l|}
26 & 193 \\
\hline
\end{tabular} 


\section{FOREST PRODUCTS INDUSTRY OF THE FUTURE - PORTFOLIO STUDY AND EVALUATION}

\section{9-941 Mill Designed Bio-Bleaching Technologies}

\begin{tabular}{|c|c|c|c|c|c|c|c|}
\hline 1 & $\begin{array}{l}\text { Suslained forest resource } \\
\text { management }\end{array}$ & \begin{tabular}{|c|} 
N/A or no \\
Significance \\
0 \\
\end{tabular} & $\begin{array}{c}\text { Some } \\
\text { Significance } \\
1\end{array}$ & 2 & \begin{tabular}{|c|} 
Moderate \\
Significance \\
3 \\
\end{tabular} & 4 & $\begin{array}{c}\text { High } \\
\text { Significance } \\
5 \\
5\end{array}$ \\
\hline 2 & $\begin{array}{l}\text { Size and extent of market } \\
\text { for the new technology }\end{array}$ & \begin{tabular}{|c|} 
very Small \\
0
\end{tabular} & $\begin{array}{c}\text { Small } \\
1\end{array}$ & 2 & $\begin{array}{c}\text { Medium } \\
3\end{array}$ & 4 & $\begin{array}{l}\text { Large } \\
5\end{array}$ \\
\hline 3 & Energy performance & \begin{tabular}{|c|} 
N/A ar no \\
Significance \\
0 \\
\end{tabular} & $\begin{array}{c}\text { Some } \\
\text { Significance } \\
1 \\
1\end{array}$ & 2 & \begin{tabular}{|c|} 
Moderate \\
Significance \\
3 \\
\end{tabular} & 4 & $\begin{array}{c}\text { High } \\
\text { Significance } \\
5 \\
5\end{array}$ \\
\hline 4 & Economic attradiveness & \begin{tabular}{|c|} 
Unattractive \\
0
\end{tabular} & $\begin{array}{c}\begin{array}{c}\text { Somewhat } \\
\text { Attractive } \\
1\end{array} \\
\end{array}$ & 2 & \begin{tabular}{|c} 
Altractive \\
3 \\
3
\end{tabular} & 4 & 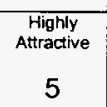 \\
\hline 5 & Technology champion & $\begin{array}{l}\text { None } \\
0\end{array}$ & \begin{tabular}{|c|} 
Assigned \\
Champion \\
1 \\
\end{tabular} & 2 & \begin{tabular}{|c|} 
Independent \\
Champion \\
3
\end{tabular} & 4 & $\begin{array}{c}\text { Multiple } \\
\text { Champions } \\
5\end{array}$ \\
\hline 6 & $\begin{array}{l}\text { Sccientific insights derived } \\
\text { from project }\end{array}$ & \begin{tabular}{|c|} 
N/A or no \\
Significance \\
0 \\
\end{tabular} & $\begin{array}{c}\text { Some } \\
\text { Significance } \\
1 \\
1\end{array}$ & 2 & \begin{tabular}{|c|} 
Moderate \\
Significance \\
3 \\
\end{tabular} & 4 & $\begin{array}{c}\text { High } \\
\text { Significance } \\
5 \\
5\end{array}$ \\
\hline 7 & $\begin{array}{l}\text { Improved environmental } \\
\text { performance }\end{array}$ & \begin{tabular}{|c|} 
N/A or no \\
Significance \\
0 \\
\end{tabular} & \begin{tabular}{|c|} 
Some \\
Significance \\
1 \\
1
\end{tabular} & 2 & \begin{tabular}{c|}
$\begin{array}{c}\text { Moderate } \\
\text { Significance }\end{array}$ \\
3
\end{tabular} & 4 & $\begin{array}{c}\text { High } \\
\text { Significance } \\
5 \\
5\end{array}$ \\
\hline 8 & Technological leadership & \begin{tabular}{|c|} 
N/A or no \\
Significance \\
0 \\
\end{tabular} & $\begin{array}{c}\text { Some } \\
\text { Significance } \\
1 \\
1\end{array}$ & 2 & \begin{tabular}{c|}
$\begin{array}{c}\text { Moderate } \\
\text { Significance }\end{array}$ \\
$\mathbf{3}$
\end{tabular} & 4 & $\begin{array}{c}\text { High } \\
\text { Significance } \\
5 \\
5\end{array}$ \\
\hline 9 & $\begin{array}{l}\text { Reeyded wood and paper } \\
\text { materizis }\end{array}$ & \begin{tabular}{|c|} 
N/A or no \\
Significance \\
0 \\
\end{tabular} & $\begin{array}{c}\text { Some } \\
\text { Significance } \\
1 \\
1\end{array}$ & 2 & \begin{tabular}{c|} 
Moderate \\
Significance \\
3
\end{tabular} & 4 & $\begin{array}{c}\text { High } \\
\text { Significance } \\
5\end{array}$ \\
\hline 10 & Risk & \begin{tabular}{|c|} 
High Risk \\
0 \\
\end{tabular} & \begin{tabular}{|c|}
$\begin{array}{c}\text { Moderate } \\
\text { Risk } \\
1\end{array}$ \\
1
\end{tabular} & 2 & $\begin{array}{c}\text { Low Risk } \\
3\end{array}$ & 4 & $\begin{array}{c}\text { Very Low } \\
\text { Risk } \\
5 \\
5\end{array}$ \\
\hline 11 & Alternate uses for biomass & \begin{tabular}{|c|} 
N/A or no \\
Significance \\
0 \\
\end{tabular} & $\begin{array}{c}\text { Some } \\
\text { Significance } \\
1\end{array}$ & 2 & $\begin{array}{c}\begin{array}{c}\text { Moderate } \\
\text { Significance } \\
3\end{array} \\
3\end{array}$ & 4 & $\begin{array}{c}\text { High } \\
\text { Significance } \\
5\end{array}$ \\
\hline
\end{tabular}

Totals

\begin{tabular}{|c|c|c|}
\hline $\begin{array}{c}\text { CTO } \\
\text { Weighting }\end{array}$ & $\begin{array}{c}\text { Raw } \\
\text { Rating }\end{array}$ & $\begin{array}{l}\text { Weighted } \\
\text { Rating }\end{array}$ \\
\hline 10 & 4 & 40 \\
\hline $\begin{array}{c}\text { CTO } \\
\text { Weighting }\end{array}$ & $\begin{array}{c}\text { Raw } \\
\text { Rating }\end{array}$ & $\begin{array}{c}\text { Weighted } \\
\text { Rating }\end{array}$ \\
\hline 9 & 5 & 45 \\
\hline $\begin{array}{c}\text { CTO } \\
\text { Weighting }\end{array}$ & $\begin{array}{c}\text { Raw } \\
\text { Rating }\end{array}$ & $\begin{array}{c}\text { Weighted } \\
\text { Rating }\end{array}$ \\
\hline 8 & 4 & 32 \\
\hline $\begin{array}{c}\text { CTO } \\
\text { Weighting }\end{array}$ & $\begin{array}{c}\text { Raw } \\
\text { Rating }\end{array}$ & $\begin{array}{c}\text { Weighted } \\
\text { Rating }\end{array}$ \\
\hline 8 & 5 & 40 \\
\hline $\begin{array}{c}\text { CTO } \\
\text { Weighting }\end{array}$ & $\begin{array}{c}\text { Raw } \\
\text { Rating }\end{array}$ & $\begin{array}{c}\text { Weighted } \\
\text { Rating }\end{array}$ \\
\hline 7 & 3 & 21 \\
\hline $\begin{array}{c}\text { CTO } \\
\text { Weighting }\end{array}$ & $\begin{array}{c}\text { Raw } \\
\text { Rating }\end{array}$ & $\begin{array}{c}\text { Weighted } \\
\text { Rating }\end{array}$ \\
\hline 7 & 4 & 28 \\
\hline $\begin{array}{c}\text { CTO } \\
\text { Weighting }\end{array}$ & $\begin{array}{c}\text { Raw } \\
\text { Rating }\end{array}$ & $\begin{array}{c}\text { Weighted } \\
\text { Rating }\end{array}$ \\
\hline 7 & 3 & 21 \\
\hline $\begin{array}{c}\text { CTOO } \\
\text { Weighting }\end{array}$ & $\begin{array}{c}\text { Raw } \\
\text { Rating }\end{array}$ & $\begin{array}{c}\text { Weighted } \\
\text { Rating }\end{array}$ \\
\hline 7 & 3 & 21 \\
\hline $\begin{array}{l}\text { CTO } \\
\text { Weighting }\end{array}$ & $\begin{array}{c}\text { Raw } \\
\text { Rating }\end{array}$ & $\begin{array}{l}\text { Weighted } \\
\text { Rating }\end{array}$ \\
\hline 6 & 0 & 0 \\
\hline $\begin{array}{c}\text { CTO } \\
\text { Weighting }\end{array}$ & $\begin{array}{c}\text { Raw } \\
\text { Rating }\end{array}$ & $\begin{array}{l}\text { Weighted } \\
\text { Rating }\end{array}$ \\
\hline 6 & 4 & 24 \\
\hline $\begin{array}{c}\text { CTO } \\
\text { Weighting }\end{array}$ & $\begin{array}{c}\text { Raw } \\
\text { Rating }\end{array}$ & \begin{tabular}{|c|} 
Weighted \\
Rating
\end{tabular} \\
\hline 5 & 1 & 5 \\
\hline
\end{tabular}

Technology can increase yield by being able to de-lignify higher Kappa number pulps which will allow shorter digester times resulting in higher pulp yields and reduced harvest demand.

Applicable to all bleached Kraft operations.

Reduction in process time in the digesters. This will use less energy while giving a higher pulp yield with a higher Kappa number, which can be effectively de-lignified with the LMS process. Technology also allows the elimination of a bleaching stage, either $\mathrm{O}_{2}$ or 1 st stage of $\mathrm{D}_{0}$ stage. LMS operates at lower temperature and at lower pressure.

This offers an alternative bleaching process with a low capital requirement and low operating expense. No major capital expenditures are required to implement. Economic benefits will be higher pulp yield, lower water usage with reduced chloride/AOXCOD in bleach effluents. Enzyme manufacturers.

Development and validation of the model to predict the generation of VOC.

Reduction of Chlorides/AOX and COD levels in the bleach plant effluents. Indirect benefits in reduced energy at the digester from lower cycle times and in the production of ClO

Paprican, NC State and Hercules are working on this but IPST has demonstrated the pulp yield benefits.

Not Applicable.

Research project: Some concern is finding the most cost efficient mediator.

Commercialization: The technology poses little risk to operations since it can be initiated with almost no capital and does not require abandonment of current practices. Some operational risks inherent in Kraft pulp mills are reduced since process runs at lower temperature and pressure and has less chloride/AOX/COD in the effluents.

$\mathrm{PI}$ and Co-PI believe that there may be a good possibility that these methods can lead to a process of direct production of electricity from biomass. 
11-1150 Use of Residual Solids in Concrete

\begin{tabular}{|c|c|c|c|c|c|c|c|}
\hline 1 & $\begin{array}{l}\text { Sustained forest resource } \\
\text { management }\end{array}$ & \begin{tabular}{|c} 
N/A or no \\
Significance \\
0
\end{tabular} & $\begin{array}{c}\text { Some } \\
\text { Significance } \\
1 \\
1\end{array}$ & 2 & \begin{tabular}{|c} 
Moderate \\
Significance \\
3
\end{tabular} & 4 & \begin{tabular}{|c} 
High \\
Significance \\
5 \\
5
\end{tabular} \\
\hline 2 & $\begin{array}{l}\text { Size and extent of market } \\
\text { for the new technology }\end{array}$ & \begin{tabular}{|c} 
Very Small \\
0
\end{tabular} & $\begin{array}{c}\text { Small } \\
1\end{array}$ & 2 & $\begin{array}{c}\text { Medium } \\
3\end{array}$ & 4 & $\begin{array}{l}\text { Large } \\
5\end{array}$ \\
\hline 3 & Energy pertormance & \begin{tabular}{|c|} 
N/A or no \\
Significance \\
0 \\
0
\end{tabular} & $\begin{array}{c}\text { Some } \\
\text { Significance } \\
1 \\
1\end{array}$ & 2 & \begin{tabular}{|c|} 
Moderate \\
Significance \\
3 \\
3
\end{tabular} & 4 & \begin{tabular}{|c|} 
High \\
Significance \\
5 \\
\end{tabular} \\
\hline 4 & Economic attrativeness & $\begin{array}{c}\text { Unattractive } \\
0\end{array}$ & \begin{tabular}{|c|} 
Somemhat \\
Attractive \\
1
\end{tabular} & 2 & $\begin{array}{c}\text { Altractive } \\
3\end{array}$ & 4 & $\begin{array}{c}\text { Highly } \\
\text { Attractive } \\
5\end{array}$ \\
\hline 5 & Technology champion & $\begin{array}{c}\text { None } \\
0\end{array}$ & $\begin{array}{c}\text { Assigned } \\
\text { Cnampion } \\
1\end{array}$ & 2 & \begin{tabular}{|c} 
independent \\
Champion \\
3
\end{tabular} & 4 & \begin{tabular}{|c} 
Multiple \\
Champions \\
5
\end{tabular} \\
\hline 6 & $\begin{array}{l}\text { Scientific insights derived } \\
\text { trom project }\end{array}$ & \begin{tabular}{|c} 
N/A or no \\
Significance \\
0
\end{tabular} & \begin{tabular}{|c|} 
Some \\
Significance \\
1
\end{tabular} & 2 & \begin{tabular}{|c} 
Moderate \\
Significance \\
3 \\
\end{tabular} & 4 & \begin{tabular}{|c|} 
High \\
Significance \\
5 \\
5
\end{tabular} \\
\hline 7 & $\begin{array}{l}\text { improved environmental } \\
\text { performance }\end{array}$ & \begin{tabular}{|c} 
N/A or no \\
Significance \\
0 \\
0
\end{tabular} & \begin{tabular}{|c|} 
Some \\
Significance \\
1 \\
1
\end{tabular} & 2 & \begin{tabular}{|c|} 
Moderate \\
Significance \\
3
\end{tabular} & 4 & \begin{tabular}{|c|} 
High \\
Significance \\
5 \\
5
\end{tabular} \\
\hline 8 & Technological leadership & \begin{tabular}{|c|} 
N/A of no \\
Significance \\
0
\end{tabular} & \begin{tabular}{|c} 
Some \\
Significance \\
1
\end{tabular} & 2 & $\begin{array}{c}\text { Moderate } \\
\text { Significance } \\
3\end{array}$ & 4 & \begin{tabular}{|c|} 
High \\
Significance \\
5
\end{tabular} \\
\hline 9 & $\begin{array}{l}\text { Recycled wood and paper } \\
\text { materials }\end{array}$ & $\begin{array}{c}\text { N/A or no } \\
\text { Significance } \\
0\end{array}$ & \begin{tabular}{|c} 
Some \\
Significance \\
1
\end{tabular} & 2 & \begin{tabular}{|c|} 
Moderate \\
Signrificance \\
3
\end{tabular} & 4 & \begin{tabular}{|c} 
High \\
Significance \\
5
\end{tabular} \\
\hline 10 & Risk & $\begin{array}{c}\text { High Risk } \\
0\end{array}$ & $\begin{array}{c}\begin{array}{c}\text { Moderate } \\
\text { Risk } \\
1\end{array} \\
1\end{array}$ & 2 & $\begin{array}{c}\text { Low Risk } \\
3\end{array}$ & 4 & \begin{tabular}{|c|} 
Ven Low \\
Risk \\
5
\end{tabular} \\
\hline 11 & Alternate uses for biomass & \begin{tabular}{|c|} 
N/A or no \\
Significance \\
0
\end{tabular} & $\begin{array}{c}\text { Some } \\
\text { Significance } \\
1 \\
1\end{array}$ & 2 & \begin{tabular}{|c|} 
Moderate \\
Significance \\
3
\end{tabular} & 4 & $\begin{array}{c}\text { High } \\
\text { Significeance } \\
5 \\
5\end{array}$ \\
\hline
\end{tabular}

Totals

\begin{tabular}{|c|c|c|}
\hline $\begin{array}{c}\text { CTO } \\
\text { Weighting }\end{array}$ & $\begin{array}{c}\text { Raw } \\
\text { Rating }\end{array}$ & \begin{tabular}{|c|} 
Weighted \\
Rating
\end{tabular} \\
\hline 10 & 0 & 0 \\
\hline $\begin{array}{c}\text { CTO } \\
\text { Weighting }\end{array}$ & $\begin{array}{l}\text { Raw } \\
\text { Rating }\end{array}$ & $\begin{array}{c}\text { Weighted } \\
\text { Rating }\end{array}$ \\
\hline 9 & 2 & 18 \\
\hline $\begin{array}{c}\text { CTO } \\
\text { Weighting }\end{array}$ & $\begin{array}{l}\text { Raw } \\
\text { Rating }\end{array}$ & $\begin{array}{l}\text { Weighted } \\
\text { Rating }\end{array}$ \\
\hline 8 & 1 & 8 \\
\hline $\begin{array}{c}\text { CTO } \\
\text { Weighting }\end{array}$ & $\begin{array}{l}\text { Raw } \\
\text { Rating }\end{array}$ & \begin{tabular}{|c|} 
Weighted \\
Rating
\end{tabular} \\
\hline 8 & 4 & 32 \\
\hline $\begin{array}{c}\text { CTO } \\
\text { Weighting }\end{array}$ & $\begin{array}{l}\text { Raw } \\
\text { Rating }\end{array}$ & $\begin{array}{c}\text { Weighted } \\
\text { Rating }\end{array}$ \\
\hline 7 & 0 & 0 \\
\hline $\begin{array}{c}\text { CTO } \\
\text { Weighting }\end{array}$ & $\begin{array}{c}\text { Raw } \\
\text { Rating }\end{array}$ & \begin{tabular}{|c} 
Weighted \\
Rating
\end{tabular} \\
\hline 7 & 3 & 21 \\
\hline $\begin{array}{c}\text { CTO } \\
\text { Weighting }\end{array}$ & $\begin{array}{l}\text { Raw } \\
\text { Rating }\end{array}$ & $\begin{array}{c}\text { Weighted } \\
\text { Rating }\end{array}$ \\
\hline 7 & 3 & 21 \\
\hline $\begin{array}{c}\text { CTO } \\
\text { weighting }\end{array}$ & $\begin{array}{l}\text { Raw } \\
\text { Rating }\end{array}$ & $\begin{array}{c}\text { Weighted } \\
\text { Rating }\end{array}$ \\
\hline 7 & 2 & 14 \\
\hline $\begin{array}{c}\text { CTO } \\
\text { Weighting }\end{array}$ & $\begin{array}{l}\text { Raw } \\
\text { Rating }\end{array}$ & $\begin{array}{c}\text { Weighted } \\
\text { Rating }\end{array}$ \\
\hline 6 & 4 & 24 \\
\hline $\begin{array}{c}\text { CTO } \\
\text { Weighting }\end{array}$ & $\begin{array}{l}\text { Raw } \\
\text { Rating }\end{array}$ & $\begin{array}{c}\text { Weighted } \\
\text { Rating }\end{array}$ \\
\hline 6 & 1 & 6 \\
\hline $\begin{array}{c}\text { CTO } \\
\text { Weighting }\end{array}$ & $\begin{array}{l}\text { Raw } \\
\text { Rating }\end{array}$ & $\begin{array}{c}\text { Weighted } \\
\text { Rating }\end{array}$ \\
\hline 5 & 0 & 0 \\
\hline
\end{tabular}

Not applicable.

The potential market for fiber reinforced concrete is large but penetration will likely be slow due to the fragmented nature of the ready-mix industry and the reluctance to try new technology.

The energy savings as described in the proposal claims that the new "sludge" reinforced concrete will last longer and ultimately will not require replacement as frequently. These energy "benefits" are questionable since they will come only as fewer replacement yards of concrete are needed in the future because of a longer life of the fiber reinforced concrete. Minimal Capital required. Assuming a reasonably low price to ready-mix plants (approximately the same as disposal cost $\sim 33 /$ ton) the cost to furnish fiber reinforced concrete would not be much greater than non-fiber reinforced concrete. The longer life of the product might allow ready-mix concrete producers to compete more effectively with asphalt producers for government paving jobs.

None.

Breakthroughs in first year. (1) \% of sludge material to maximize concrete strength; analysis of properties of concrete made with paper mill sludge; (2) confirmation that sludge components do not interfere with or degrade concrete.

Based on the assumption that this fiber reinforced concrete will ultimately result in decreased need for new concrete in the future, fewer tons of cement (at 6x106 BTUs per ton to produce and 1 ton of $\mathrm{CO}_{2}$ released per ton of cement produced) would be produced. Also, lesser amounts of sludge would be sent to solid waste disposal sites.

Concept is not new although use of paper mill sludge could provide a good synergistic solution to the need for fiber reinforcement and the problem of disposing of the sludge.

Paper mill sludge used as fiber reinforcement for ready-mixed concrete.

Essentially no risk to success of the research. Risk in commercialization is variable sludge characteristics and quantities and lack of interest by the various paper companies in providing a consistent supply of sludge. Pl mentioned a similar issue with the use of fly ash in concrete. Fly ash was first used over 60 years ago and yet some producers of fly ash still throw theirs away rather than selling it to concrete producers.

Demonstration that wood fibers can be successfully used for concrete could lead to other fibrous biomass products that might be used in concrete. 


\section{FOREST PRODUCTS INDUSTRY OF THE FUTURE - PORTFOLIO STUDY AND EVALUATION}

12-1151 Low Temperature Plasma Technologies for Treating VOC Emissions

\begin{tabular}{|c|c|c|c|c|c|c|c|}
\hline 1 & $\begin{array}{l}\text { Sustained forest resource } \\
\text { managenent }\end{array}$ & $\begin{array}{c}\text { N/A or no } \\
\text { Significance } \\
0\end{array}$ & $\begin{array}{c}\text { Some } \\
\text { Significance } \\
1 \\
1\end{array}$ & 2 & \begin{tabular}{|c|} 
Moderate \\
Slgnificance \\
3
\end{tabular} & 4 & \begin{tabular}{|c|} 
High \\
Significance \\
5
\end{tabular} \\
\hline 2 & $\begin{array}{l}\text { Size and extent of market } \\
\text { for the new lechnology }\end{array}$ & \begin{tabular}{|c} 
Very Small \\
0
\end{tabular} & $\begin{array}{c}\text { Small } \\
1\end{array}$ & 2 & $\begin{array}{c}\text { Medium } \\
3\end{array}$ & 4 & $\begin{array}{l}\text { Large } \\
5 \\
5\end{array}$ \\
\hline 3 & Energy perfornance & \begin{tabular}{|c} 
N/A or no \\
Significance \\
0
\end{tabular} & $\begin{array}{c}\text { Some } \\
\text { Significance } \\
1 \\
1\end{array}$ & 2 & $\begin{array}{c}\text { Moderate } \\
\text { Significance } \\
3 \\
\end{array}$ & 4 & \begin{tabular}{|c|} 
High \\
Significance \\
5
\end{tabular} \\
\hline 4 & Economic attradiveness & $\begin{array}{c}\text { Unattractive } \\
0\end{array}$ & $\begin{array}{c}\text { Somewhat } \\
\text { Atractive } \\
1\end{array}$ & 2 & \begin{tabular}{|c|} 
Attractive \\
3 \\
\end{tabular} & 4 & $\begin{array}{c}\text { Highly } \\
\text { Attractive } \\
5 \\
5\end{array}$ \\
\hline 5 & Technology champion & $\begin{array}{c}\text { None } \\
0 \\
0\end{array}$ & $\begin{array}{c}\text { Assigned } \\
\text { Champion } \\
1\end{array}$ & 2 & $\begin{array}{c}\text { independent } \\
\text { Champion } \\
3\end{array}$ & 4 & $\begin{array}{c}\text { Muttiple } \\
\text { Champions } \\
5\end{array}$ \\
\hline 6 & $\begin{array}{l}\text { Scientific insights derived } \\
\text { from project }\end{array}$ & $\begin{array}{c}\text { N/A or no } \\
\text { Signnificance } \\
0\end{array}$ & $\begin{array}{c}\text { Some } \\
\text { Significance } \\
1 \\
1\end{array}$ & 2 & $\begin{array}{c}\text { Moderate } \\
\text { significance } \\
3\end{array}$ & 4 & $\begin{array}{c}\text { High } \\
\text { Significance } \\
5\end{array}$ \\
\hline 7 & $\begin{array}{l}\text { Improved environmental } \\
\text { performance }\end{array}$ & $\begin{array}{c}\text { N/A or no } \\
\text { Significance } \\
0\end{array}$ & $\begin{array}{c}\text { Some } \\
\text { Significance } \\
1 \\
1\end{array}$ & 2 & $\begin{array}{c}\text { Moderate } \\
\text { Significance } \\
3\end{array}$ & 4 & $\begin{array}{c}\text { Hign } \\
\text { Significance } \\
5\end{array}$ \\
\hline 8 & Technological leadership & \begin{tabular}{|c|} 
N/A or no \\
Significance \\
0 \\
0
\end{tabular} & $\begin{array}{c}\text { Some } \\
\text { Significance } \\
1 \\
1\end{array}$ & 2 & $\begin{array}{c}\text { Moderate } \\
\text { significance } \\
3 \\
\end{array}$ & 4 & $\begin{array}{c}\text { High } \\
\text { Significance } \\
5 \\
5\end{array}$ \\
\hline 9 & $\begin{array}{l}\text { Recycled wood and paper } \\
\text { materials }\end{array}$ & \begin{tabular}{|c} 
N/A or no \\
Siggnificance \\
0 \\
0
\end{tabular} & $\begin{array}{c}\text { Some } \\
\text { Significance } \\
1 \\
1\end{array}$ & 2 & $\begin{array}{c}\text { Moderate } \\
\text { significance } \\
3 \\
3\end{array}$ & 4 & \begin{tabular}{|c}
$\begin{array}{c}\text { High } \\
\text { Significance } \\
5\end{array}$ \\
\end{tabular} \\
\hline 10 & Risk & \begin{tabular}{|c} 
High Risk \\
0
\end{tabular} & \begin{tabular}{|c|}
$\begin{array}{c}\text { Moderate } \\
\text { Risk }\end{array}$ \\
1
\end{tabular} & 2 & \begin{tabular}{|c|} 
Low Risk \\
3 \\
\end{tabular} & 4 & $\begin{array}{c}\text { Very Low } \\
\text { Risk } \\
5\end{array}$ \\
\hline 11 & Attemate uses for biomass & \begin{tabular}{|c} 
N/A or no \\
Significance \\
0
\end{tabular} & $\begin{array}{c}\text { Some } \\
\text { Significance } \\
1 \\
1\end{array}$ & 2 & \begin{tabular}{|c|} 
Moderate \\
Significance \\
3 \\
3
\end{tabular} & 4 & \begin{tabular}{|c} 
High \\
Significance \\
5
\end{tabular} \\
\hline
\end{tabular}

Totals

\begin{tabular}{|c|c|c|}
\hline $\begin{array}{c}\text { CTO } \\
\text { Weighting }\end{array}$ & $\begin{array}{c}\text { Raw } \\
\text { Rating }\end{array}$ & $\begin{array}{c}\text { Weighted } \\
\text { Rating }\end{array}$ \\
\hline 10 & 0 & 0 \\
\hline $\begin{array}{c}\text { CTO } \\
\text { Weighting }\end{array}$ & $\begin{array}{c}\text { Raw } \\
\text { Rating }\end{array}$ & $\begin{array}{l}\text { Weighted } \\
\text { Rating }\end{array}$ \\
\hline 9 & 5 & 45 \\
\hline $\begin{array}{c}\text { CTO } \\
\text { Weighting }\end{array}$ & $\begin{array}{c}\text { Raw } \\
\text { Rating }\end{array}$ & $\begin{array}{c}\text { Weighted } \\
\text { Rating }\end{array}$ \\
\hline 8 & 3 & 24 \\
\hline $\begin{array}{c}\text { CTO } \\
\text { Weighting }\end{array}$ & $\begin{array}{l}\text { Raw } \\
\text { Rating }\end{array}$ & \begin{tabular}{|c} 
Weighted \\
Rating
\end{tabular} \\
\hline 8 & 4 & 32 \\
\hline $\begin{array}{c}\text { CTO } \\
\text { Weighting }\end{array}$ & $\begin{array}{l}\text { Raw } \\
\text { Rating }\end{array}$ & $\begin{array}{l}\text { Weighted } \\
\text { Rating }\end{array}$ \\
\hline 7 & 3 & 21 \\
\hline $\begin{array}{c}\text { CTO } \\
\text { Weighting }\end{array}$ & $\begin{array}{c}\text { Raw } \\
\text { Rating }\end{array}$ & $\begin{array}{c}\text { Weighted } \\
\text { Rating }\end{array}$ \\
\hline 7 & 4 & 28 \\
\hline $\begin{array}{c}\text { CTO } \\
\text { Weighting }\end{array}$ & $\begin{array}{c}\text { Raw } \\
\text { Rating }\end{array}$ & \begin{tabular}{|c} 
Weighted \\
Rating
\end{tabular} \\
\hline 7 & 5 & 35 \\
\hline $\begin{array}{c}\text { CTO } \\
\text { Weighting }\end{array}$ & $\begin{array}{c}\text { Raw } \\
\text { Rating }\end{array}$ & $\begin{array}{c}\text { Weighted } \\
\text { Rating }\end{array}$ \\
\hline 7 & 4 & 28 \\
\hline $\begin{array}{c}\text { CTO } \\
\text { Weighting }\end{array}$ & $\begin{array}{l}\text { Raw } \\
\text { Rating }\end{array}$ & $\begin{array}{c}\text { Weighted } \\
\text { Rating }\end{array}$ \\
\hline 6 & 0 & 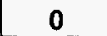 \\
\hline $\begin{array}{c}\text { CTO } \\
\text { Weighting }\end{array}$ & $\begin{array}{l}\text { Raw } \\
\text { Rating }\end{array}$ & $\begin{array}{l}\text { Weighted } \\
\text { Rating }\end{array}$ \\
\hline 6 & 3 & 18 \\
\hline $\begin{array}{c}\text { CTO } \\
\text { Weighting }\end{array}$ & $\begin{array}{l}\text { Raw } \\
\text { Rating }\end{array}$ & $\begin{array}{c}\text { Weighted } \\
\text { Rating }\end{array}$ \\
\hline 5 & 1 & 5 \\
\hline
\end{tabular}

Not applicable.

Technology applicable to higher volume, low-concentration airstreams (concentrations less than $3000 \mathrm{ppm}$ ). Applicable to many industries as well.

\section{Quarterly report indicates lower energy requirements than RTOs because the destruction} mechanism is not heat but low temperature plasma containing radicals $(\mathrm{OH})$ that react with the organic pollution molecules in the air stream. Will obviate the use of natural gas or other purchased fuel for RTOs on high volume, low-concentration airstreams. Capital cost is expected in the range of $30-50 \%$ of the capital cost for an RTO with an additional operating cost advantage on concentrations below $3000 \mathrm{ppm}$.

G-P has stated they would like to have all field tests done at G-P facilities. NCASI has planned to involve other companies in the project.

Ability to grow field quickly and to be able to pulse the plasma generation device at $1 \mathrm{KHZ}$ in 100 nanosecond bursts.

Provides way to economically treat low concentration airstreams and destroy VOCs with low energy usage.

This work is not the only effort in this area but is a leader in the low temperature plasma work.

Not applicable.

Low risk to project success. Low scientific risk in commercialization. Some risks in adapting technology to industrial environment (ruggedness, technological support).

May facilitate the use of more material that would emit naturally occurring VOCs and HAPs. Could perhaps be used on biomass piles. 


\section{FOREST PRODUCTS INDUSTRY OF THE FUTURE - PORTFOLIO STUDY AND EVALUATION}

13-1152 Control of Emissions from Wood Waste Burners and Wood Dryers

\begin{tabular}{|c|c|c|c|c|c|c|c|}
\hline 1 & $\begin{array}{l}\text { Sustained forest resource } \\
\text { managemem }\end{array}$ & $\begin{array}{c}\text { N/A or no } \\
\text { Significance } \\
0\end{array}$ & $\begin{array}{c}\text { Some } \\
\text { Significance } \\
1\end{array}$ & & $\begin{array}{c}\text { Moderate } \\
\text { Significance } \\
3 \\
3\end{array}$ & 4 & \begin{tabular}{|c}
$\begin{array}{c}\text { High } \\
\text { Significance } \\
5\end{array}$ \\
\end{tabular} \\
\hline \multirow[b]{2}{*}{2} & & \begin{tabular}{|l|} 
Very Smaill \\
\end{tabular} & Small & & Medium & & Large \\
\hline & $\begin{array}{l}\text { Size and extent of market } \\
\text { for the new technology }\end{array}$ & & & 2 & 3 & 4 & 5 \\
\hline \multirow{2}{*}{3} & IEner & $\begin{array}{l}\text { N/A or no } \\
\text { Siggificance }\end{array}$ & $\begin{array}{c}\text { Some } \\
\text { Significance }\end{array}$ & & $\begin{array}{l}\text { Moderate } \\
\text { Significance }\end{array}$ & & $\begin{array}{c}\text { High } \\
\text { Significance }\end{array}$ \\
\hline & - & 0 & 1 & 2 & 3 & 4 & 5 \\
\hline \multirow{2}{*}{4} & Economic & \begin{tabular}{|l} 
Unattractive \\
\end{tabular} & $\begin{array}{l}\text { Somewhat } \\
\text { Atrractive }\end{array}$ & & \begin{tabular}{|l|} 
Atractive \\
\end{tabular} & & $\begin{array}{c}\text { Highly } \\
\text { Atractive }\end{array}$ \\
\hline & f & 0 & 1 & 2 & 3 & 4 & 5 \\
\hline \multirow{2}{*}{5} & Technolagy champion & None & \begin{tabular}{|l|} 
Assigned \\
Champion \\
\end{tabular} & & $\begin{array}{c}\text { Independent } \\
\text { Champion }\end{array}$ & & \begin{tabular}{|c|} 
Multiple \\
Champions
\end{tabular} \\
\hline & Ther & 0 & 1 & 2 & 3 & 4 & 5 \\
\hline \multirow{2}{*}{6} & \multirow{2}{*}{$\begin{array}{l}\text { Scientific insights derived } \\
\text { from project }\end{array}$} & $\begin{array}{l}\text { N/A or no } \\
\text { Significance }\end{array}$ & \begin{tabular}{|c|} 
Some \\
Significance
\end{tabular} & & \begin{tabular}{|l} 
Moderate \\
Significance
\end{tabular} & & $\begin{array}{c}\text { High } \\
\text { Significance }\end{array}$ \\
\hline & & 0 & 1 & 2 & 3 & 4 & 5 \\
\hline \multirow{2}{*}{7} & \multirow{2}{*}{$\begin{array}{l}\text { Improved ervironmental } \\
\text { performance }\end{array}$} & $\begin{array}{l}\text { N/A or no } \\
\text { Significance }\end{array}$ & $\begin{array}{l}\text { Some } \\
\text { Significance }\end{array}$ & & $\begin{array}{l}\text { Moderate } \\
\text { Significance }\end{array}$ & & $\begin{array}{l}\text { High } \\
\text { Significance }\end{array}$ \\
\hline & & 0 & 1 & 2 & 3 & 4 & 5 \\
\hline \multirow{2}{*}{8} & \multirow{2}{*}{ Tecthological leadership } & $\begin{array}{l}\text { N/A of no } \\
\text { Significance }\end{array}$ & \begin{tabular}{|l|} 
Some \\
Significance
\end{tabular} & & $\begin{array}{l}\text { Moderate } \\
\text { Significance }\end{array}$ & & $\begin{array}{c}\text { High } \\
\text { Significance }\end{array}$ \\
\hline & & 0 & 1 & 2 & 3 & 4 & 5 \\
\hline \multirow{2}{*}{9} & \multirow{2}{*}{$\begin{array}{l}\begin{array}{l}\text { Recycled wood and paper } \\
\text { materials }\end{array} \\
\end{array}$} & \begin{tabular}{|l|} 
N/A or no \\
Significance
\end{tabular} & \begin{tabular}{|l|} 
Some \\
Significance
\end{tabular} & & \begin{tabular}{|l} 
Moderate \\
Significance
\end{tabular} & & $\begin{array}{c}\text { High } \\
\text { Significance }\end{array}$ \\
\hline & & 0 & 1 & 2 & 3 & 4 & 5 \\
\hline \multirow{2}{*}{10} & \multirow{2}{*}{ Risk } & High Risk & $\begin{array}{c}\begin{array}{c}\text { Moderate } \\
\text { Risk }\end{array} \\
\end{array}$ & & Low Risk & & $\begin{array}{c}\text { Very Low } \\
\text { Risk }\end{array}$ \\
\hline & & 0 & 1 & 2 & 3 & 4 & 5 \\
\hline \multirow{2}{*}{11} & \multirow{2}{*}{ Atternate uses for biomass } & $\begin{array}{l}\text { N/A of no } \\
\text { Significance }\end{array}$ & $\begin{array}{l}\text { Some } \\
\text { Significance }\end{array}$ & & \begin{tabular}{|l|} 
Moderate \\
Significance
\end{tabular} & & $\begin{array}{l}\text { High } \\
\text { Significance }\end{array}$ \\
\hline & & 0 & 1 & 2 & 3 & 4 & 5 \\
\hline
\end{tabular}

Totals

\section{Comments}

\begin{tabular}{|c|c|c|}
\hline $\begin{array}{c}\text { Cro } \\
\text { Weighting }\end{array}$ & $\begin{array}{l}\text { Raw } \\
\text { Rating }\end{array}$ & $\begin{array}{c}\text { Weighted } \\
\text { Rating }\end{array}$ \\
\hline 10 & 0 & 0 \\
\hline $\begin{array}{c}\text { CTO } \\
\text { Weighting }\end{array}$ & $\begin{array}{l}\text { Raw } \\
\text { Rating }\end{array}$ & $\begin{array}{c}\text { Weighted } \\
\text { Rating }\end{array}$ \\
\hline 9 & 4 & 36 \\
\hline $\begin{array}{c}\text { CTO } \\
\text { Weighting }\end{array}$ & $\begin{array}{l}\text { Raw } \\
\text { Rating }\end{array}$ & \begin{tabular}{|c|} 
Weighted \\
Rating
\end{tabular} \\
\hline 8 & 2 & 16 \\
\hline $\begin{array}{c}\text { Cro } \\
\text { Weighting }\end{array}$ & $\begin{array}{l}\text { Raw } \\
\text { Rating }\end{array}$ & \begin{tabular}{|c|} 
Weighted \\
Rating
\end{tabular} \\
\hline 8 & 4 & 32 \\
\hline $\begin{array}{c}\text { CTO } \\
\text { Weighting }\end{array}$ & $\begin{array}{c}\text { Raw } \\
\text { Rating }\end{array}$ & $\begin{array}{c}\text { Weighted } \\
\text { Rating }\end{array}$ \\
\hline 7 & 2 & 14 \\
\hline $\begin{array}{c}\text { CTO } \\
\text { Weighting }\end{array}$ & $\begin{array}{l}\text { Raw } \\
\text { Rating }\end{array}$ & $\begin{array}{c}\text { Weighted } \\
\text { Rating }\end{array}$ \\
\hline 7 & 3 & 2 \\
\hline $\begin{array}{c}\text { CTO } \\
\text { Weighting }\end{array}$ & $\begin{array}{l}\text { Raw } \\
\text { Rating }\end{array}$ & $\begin{array}{c}\text { Weighted } \\
\text { Rating }\end{array}$ \\
\hline 7 & 4 & 28 \\
\hline $\begin{array}{c}\text { CTO } \\
\text { Weighting }\end{array}$ & $\begin{array}{c}\text { Raw } \\
\text { Rating }\end{array}$ & $\begin{array}{c}\text { Weighted } \\
\text { Rating }\end{array}$ \\
\hline 7 & 4 & 28 \\
\hline $\begin{array}{c}\text { CTO } \\
\text { Weighting }\end{array}$ & $\begin{array}{c}\text { Raw } \\
\text { Rating }\end{array}$ & $\begin{array}{c}\text { Weighted } \\
\text { Rating }\end{array}$ \\
\hline 6 & 0 & 0 \\
\hline $\begin{array}{c}\text { CTO } \\
\text { Weighting }\end{array}$ & $\begin{array}{l}\text { Raw } \\
\text { Rating }\end{array}$ & \begin{tabular}{|c|} 
Weighted \\
Rating
\end{tabular} \\
\hline 6 & 3 & 18 \\
\hline $\begin{array}{c}\text { CTO } \\
\text { Weighting }\end{array}$ & $\begin{array}{l}\text { Raw } \\
\text { Rating }\end{array}$ & $\begin{array}{c}\text { Weighted } \\
\text { Rating }\end{array}$ \\
\hline 5 & 3 & 15 \\
\hline
\end{tabular}

Not applicable.

Applicable to a wide area of the forest products industry. Suspension burning is common in the forest products business.

This research will facilitate the continued use of wood waste fuels and save fossil fuels that might otherwise be used to replace renewable wood fuels.

Application of the knowledge gained from this research promises to be relatively easy to implement at low cost.

None specifically identified although Co-chair indicates that there is wide interest in this project.

Knowledge of combustion and how to control suspension burners to minimize generation of $\mathrm{NO}_{\mathrm{x}}$. Co-chair described this project as "really important work".

Wood waste burners are responsible for a significant fraction of the $\mathrm{NO}_{\mathrm{x}}$ emitted from burning of industrial wood wastes. PI states that $\mathrm{NO}_{x}$ emissions can be controlled to less than 100 $\mathrm{ppm}$. This will be significant to enable the increased use of waste wood fuels. Co-chair described this work as "superb". Little other work being done in this area.

Not Applicable.

PI states risk is mid range. Risk to application is more social/cultural than technological.

Potential hardware changes to control fuel injection and air patterns are relatively easy to accomplish.

This will facilitate increased use of biomass as a fuel. 
FOREST PRODUCTS INDUSTRY OF THE FUTURE - PORTFOLIO STUDY AND EVALUATION

14-1154 NPE Removal Using Functionalized Monolayers on Mesoporous Supports

\begin{tabular}{|c|c|c|c|c|c|c|c|}
\hline 1 & $\begin{array}{l}\text { Sustained forest resource } \\
\text { management }\end{array}$ & $\begin{array}{c}\text { N/A or no } \\
\text { Significance } \\
0\end{array}$ & \begin{tabular}{|c|} 
Some \\
Significance \\
1 \\
1
\end{tabular} & 2 & \begin{tabular}{|c|} 
Moderate \\
Significance \\
3 \\
3
\end{tabular} & 4 & \begin{tabular}{|c} 
High \\
Significance \\
5
\end{tabular} \\
\hline 2 & $\begin{array}{l}\text { Size and extent of market } \\
\text { for the new technology }\end{array}$ & $\begin{array}{c}\text { very Small } \\
0\end{array}$ & $\begin{array}{c}\text { Small } \\
1 \\
1\end{array}$ & 2 & $\begin{array}{c}\text { Medium } \\
3\end{array}$ & 4 & $\begin{array}{l}\text { Large } \\
5 \\
5\end{array}$ \\
\hline 3 & Energy perfornance & $\begin{array}{c}\text { N/A or no } \\
\text { Significance } \\
0\end{array}$ & \begin{tabular}{|c|} 
Some \\
Significance \\
1
\end{tabular} & 2 & $\begin{array}{c}\text { Moderate } \\
\text { Significance } \\
3\end{array}$ & 4 & \begin{tabular}{|c} 
High \\
Significance \\
5
\end{tabular} \\
\hline 4 & Economic atradiveness & $\begin{array}{c}\text { Unattractive } \\
0\end{array}$ & \begin{tabular}{|c|} 
Somemhat \\
Atrractive \\
1
\end{tabular} & 2 & $\begin{array}{c}\text { Atractive } \\
3\end{array}$ & 4 & $\begin{array}{c}\text { Highly } \\
\text { Attractive } \\
5\end{array}$ \\
\hline 5 & Techrology champion & $\begin{array}{c}\text { None } \\
0\end{array}$ & \begin{tabular}{|c|} 
Assigned \\
Champion \\
1 \\
\end{tabular} & 2 & \begin{tabular}{|c}
$\begin{array}{c}\text { independent } \\
\text { Champion } \\
3\end{array}$ \\
\end{tabular} & 4 & $\begin{array}{c}\text { Multiple } \\
\text { Champions } \\
5\end{array}$ \\
\hline 6 & $\begin{array}{l}\text { Sclentific insights derived } \\
\text { from project }\end{array}$ & \begin{tabular}{|c} 
N/A or no \\
Significance \\
0
\end{tabular} & \begin{tabular}{|c|} 
Some \\
significance \\
1
\end{tabular} & 2 & \begin{tabular}{|c} 
Moderate \\
Significance \\
3
\end{tabular} & 4 & \begin{tabular}{|c|c} 
High \\
Significance \\
5
\end{tabular} \\
\hline 7 & $\begin{array}{l}\text { Improved environmental } \\
\text { performance }\end{array}$ & \begin{tabular}{|c} 
N/A or mo \\
Significance \\
0
\end{tabular} & $\begin{array}{c}\text { Some } \\
\text { Significance } \\
1\end{array}$ & 2 & \begin{tabular}{|c} 
Moderate \\
Significance \\
3
\end{tabular} & 4 & $\begin{array}{c}\text { High } \\
\text { Significance } \\
5 \\
5\end{array}$ \\
\hline 8 & Technological leadership & \begin{tabular}{|c} 
N/A or no \\
Significance \\
0
\end{tabular} & \begin{tabular}{|c|} 
Some \\
Significance \\
1 \\
\end{tabular} & 2 & \begin{tabular}{|c|} 
Moderate \\
Significance \\
3 \\
3
\end{tabular} & 4 & \begin{tabular}{|c} 
High \\
Significance \\
5 \\
5
\end{tabular} \\
\hline 9 & $\begin{array}{l}\text { Recycled wood and paper } \\
\text { materials }\end{array}$ & \begin{tabular}{|c} 
N/A or no \\
Significance \\
0
\end{tabular} & \begin{tabular}{|c|} 
Some \\
Significance \\
1 \\
1
\end{tabular} & 2 & $\begin{array}{c}\text { Moderate } \\
\text { Significance } \\
3 \\
3\end{array}$ & 4 & \begin{tabular}{|c} 
High \\
Significance \\
5 \\
5
\end{tabular} \\
\hline 10 & Risk & \begin{tabular}{|c} 
High Risk \\
0
\end{tabular} & \begin{tabular}{|c}
$\begin{array}{c}\text { Moderate } \\
\text { Risk }\end{array}$ \\
1
\end{tabular} & 2 & $\begin{array}{c}\text { Low Risk } \\
3\end{array}$ & 4 & $\begin{array}{c}\begin{array}{c}\text { Very Low } \\
\text { Risk }\end{array} \\
5\end{array}$ \\
\hline 11 & Attemate uses for biomass & $\begin{array}{c}\text { N/A or no } \\
\text { Significance } \\
0\end{array}$ & \begin{tabular}{|c|} 
Some \\
Significance \\
1
\end{tabular} & 2 & \begin{tabular}{|c|} 
Moderate \\
Significance \\
3 \\
3
\end{tabular} & 4 & \begin{tabular}{|c} 
High \\
Significance \\
5
\end{tabular} \\
\hline
\end{tabular}

Totals

\begin{tabular}{|c|c|c|}
\hline $\begin{array}{c}\text { CTO } \\
\text { Weighting }\end{array}$ & $\begin{array}{c}\text { Raw } \\
\text { Rating }\end{array}$ & $\begin{array}{l}\text { Weighted } \\
\text { Rating }\end{array}$ \\
\hline 10 & 0 & 0 \\
\hline $\begin{array}{c}\text { CTO } \\
\text { Weighting }\end{array}$ & $\begin{array}{c}\text { Raw } \\
\text { Rating }\end{array}$ & $\begin{array}{l}\text { Weighted } \\
\text { Rating }\end{array}$ \\
\hline 9 & 2 & 18 \\
\hline $\begin{array}{c}\text { CTO } \\
\text { Weighting }\end{array}$ & $\begin{array}{c}\text { Raw } \\
\text { Rating }\end{array}$ & $\begin{array}{l}\text { Weighted } \\
\text { Rating }\end{array}$ \\
\hline 8 & 4 & 32 \\
\hline $\begin{array}{c}\text { CTO } \\
\text { Weighting }\end{array}$ & $\begin{array}{c}\text { Raw } \\
\text { Rating }\end{array}$ & $\begin{array}{c}\text { Weighted } \\
\text { Rating }\end{array}$ \\
\hline 8 & 3 & 24 \\
\hline $\begin{array}{c}\text { CTO } \\
\text { Weighting }\end{array}$ & $\begin{array}{l}\text { Raw } \\
\text { Rating }\end{array}$ & \begin{tabular}{|l} 
Weighted \\
Rating
\end{tabular} \\
\hline 7 & 1 & 7 \\
\hline $\begin{array}{c}\text { CTO } \\
\text { Weighting }\end{array}$ & $\begin{array}{l}\text { Raw } \\
\text { Rating }\end{array}$ & $\begin{array}{c}\text { Weighted } \\
\text { Rating }\end{array}$ \\
\hline 7 & 4 & 28 \\
\hline $\begin{array}{c}\text { CTO } \\
\text { Weighting }\end{array}$ & $\begin{array}{c}\text { Raw } \\
\text { Rating }\end{array}$ & $\begin{array}{c}\text { Weighted } \\
\text { Rating }\end{array}$ \\
\hline 7 & 5 & 35 \\
\hline $\begin{array}{c}\text { CTO } \\
\text { Weighting }\end{array}$ & $\begin{array}{c}\text { Raw } \\
\text { Rating }\end{array}$ & $\begin{array}{l}\text { Weighted } \\
\text { Rating }\end{array}$ \\
\hline 7 & 3 & 35 \\
\hline $\begin{array}{c}\text { CTO } \\
\text { Weighting }\end{array}$ & $\begin{array}{l}\text { Raw } \\
\text { Rating }\end{array}$ & $\begin{array}{l}\text { Weighted } \\
\text { Rating }\end{array}$ \\
\hline b & 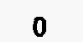 & 0 \\
\hline $\begin{array}{c}\text { CTO } \\
\text { Weighting }\end{array}$ & $\begin{array}{l}\text { Raw } \\
\text { Rating }\end{array}$ & $\begin{array}{l}\text { Weighted } \\
\text { Rating }\end{array}$ \\
\hline 6 & 2 & 12 \\
\hline $\begin{array}{c}\text { CTO } \\
\text { Weighting }\end{array}$ & $\begin{array}{l}\text { Raw } \\
\text { Rating }\end{array}$ & $\begin{array}{c}\text { Weighted } \\
\text { Rating }\end{array}$ \\
\hline 5 & 0 & 0 \\
\hline
\end{tabular}

Not applicable.

Market is bleached paper. Co chair expressed concern about material plugging the media and has doubts about reaching commercial readiness because of the nature of industrial environment. Project manager pointed out that the system, to be effective does not have to remove all the NPEs, only to keep the concentration below the scaling limits. This is important technology for bleach plant operations. Test unit that has been designed is portable and will be used in field trials as a "side-stream" filtration system. Provides an alternative to energy intensive methods for controlling buildup of NPEs.

Capital equipment cost will probably be reasonably low with the exception of the media itself. Pls are unsure of the ultimate cost of media until a manufacturer is identified. Media will have a much longer life (indefinite) as compared to classic ion exchange on an organic media which breaks down.

Interest on part of Weyerhaeuser and other companies, but no strong "champion" yet identified.

Insights into the industrial application of SAMMS

Project will facilitate the adoption of a closed loop bleach plant with the elimination of discharge streams that are environmental concerns.

PNNL is the leader in this technology. This project is a marriage of previous scientific breakthroughs in SAMMS technology.

Not significant.

PI believes there is little risk to completion of research. One hurdle to commercialization is finding an industrial partner that can manufacture the media.

Not applicable. 
FOREST PRODUCTS INDUSTRY OF THE FUTURE - PORTFOLIO STUDY AND EVALUATION

\section{5-None Effects of Fertilization and Competition Control}

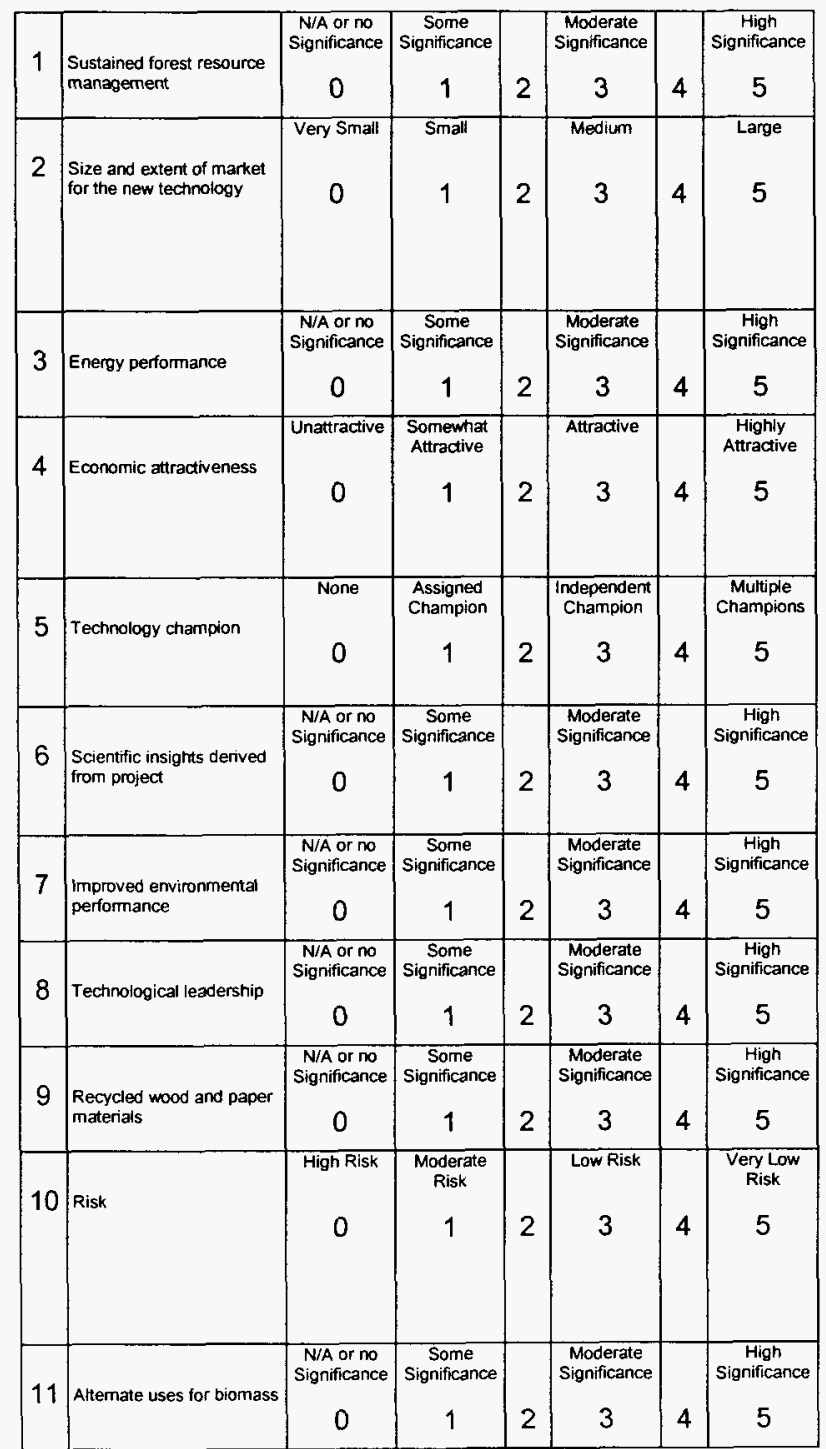

Totals

\begin{tabular}{|c|c|c|}
\hline \begin{tabular}{|c|} 
CTO \\
Weighting
\end{tabular} & $\begin{array}{l}\text { Raw } \\
\text { Rating }\end{array}$ & $\begin{array}{c}\text { Weighted } \\
\text { Rating }\end{array}$ \\
\hline 10 & 5 & 50 \\
\hline $\begin{array}{c}\text { CTO } \\
\text { Weighting }\end{array}$ & $\begin{array}{l}\text { Raw } \\
\text { Rating }\end{array}$ & $\begin{array}{c}\text { Weighted } \\
\text { Rating }\end{array}$ \\
\hline 9 & 4 & 36 \\
\hline $\begin{array}{c}\text { CTO } \\
\text { weighting }\end{array}$ & $\begin{array}{l}\text { Raw } \\
\text { Rating }\end{array}$ & $\begin{array}{l}\text { Weighted } \\
\text { Rating }\end{array}$ \\
\hline 8 & 3 & 24 \\
\hline $\begin{array}{c}\text { CTO } \\
\text { Weighting }\end{array}$ & $\begin{array}{l}\text { Raw } \\
\text { Rating }\end{array}$ & $\begin{array}{c}\text { Weighted } \\
\text { Rating }\end{array}$ \\
\hline 8 & 4 & 32 \\
\hline \begin{tabular}{|c|c|c|c|} 
CTO \\
Weighting
\end{tabular} & $\begin{array}{l}\text { Raw } \\
\text { Rating }\end{array}$ & $\begin{array}{c}\text { Weighted } \\
\text { Rating }\end{array}$ \\
\hline 7 & 5 & 35 \\
\hline \begin{tabular}{|c|c|c|} 
CTO \\
Weighting
\end{tabular} & $\begin{array}{l}\text { Raw } \\
\text { Rating }\end{array}$ & \begin{tabular}{|c} 
Weighted \\
Rating
\end{tabular} \\
\hline 7 & 4 & 28 \\
\hline \begin{tabular}{|c|c|} 
Cro \\
Weighting
\end{tabular} & $\begin{array}{l}\text { Raw } \\
\text { Rating }\end{array}$ & $\begin{array}{c}\text { Weighted } \\
\text { Rating }\end{array}$ \\
\hline 7 & 3 & 21 \\
\hline \begin{tabular}{|l} 
CTO \\
Weighting
\end{tabular} & $\begin{array}{l}\text { Raw } \\
\text { Rating }\end{array}$ & \begin{tabular}{|c|} 
Weighted \\
Rating
\end{tabular} \\
\hline 7 & 2 & 14 \\
\hline \begin{tabular}{|l|} 
CTO \\
Weighting
\end{tabular} & $\begin{array}{l}\text { Raw } \\
\text { Rating }\end{array}$ & $\begin{array}{l}\text { Weighted } \\
\text { Rating }\end{array}$ \\
\hline 0 & 0 & 0 \\
\hline \begin{tabular}{|c} 
cTO \\
Weighting
\end{tabular} & $\begin{array}{l}\text { Raw } \\
\text { Rating }\end{array}$ & $\begin{array}{l}\text { Weighted } \\
\text { Rating }\end{array}$ \\
\hline 6 & 5 & 30 \\
\hline \begin{tabular}{|c|c|c|c|c|} 
CTO \\
Weighting
\end{tabular} & $\begin{array}{l}\text { Raw } \\
\text { Rating }\end{array}$ & $\begin{array}{l}\text { Weightec } \\
\text { Rating }\end{array}$ \\
\hline 5 & 2 & 1 \\
\hline
\end{tabular}

\begin{tabular}{|l|l|}
\hline 37 & 280 \\
\hline
\end{tabular}

\section{Comments}

The main benefit from the study in regards to sustainable management will be in more per unit area production by either generating more fiber from a given land base and time period or by shortening harvest rotations through accelerated growth.

$\mathrm{PI}$ believes that carbon sequestration and the ability to manipulate the allocation of carbon will generate broad interest in the research. Preliminary results have shown that both competition control and fertilization can increase growth rates but competition control tends to cause carbon allocation in the bole of the tree more than in other parts of the tree in Slash. PI believes that this will be true in Loblolly as well. Co-chair perceived that the market impact would be great for this technology.

Some indirect energy benefits can be realized through more efficient use of fertilizers and herbicides. More carbon (biomass) can be accumulated through increased growth.

The proper timing and rates of application for competition control and fertilizer to obtain increased growth are the driving forces behind the economic attractiveness to industry. Competition control and fertilization give similar results in different ways. Understanding these differences and proper use of competition control and fertilization will make the use of the improvement practices more economically attractive.

Nine industry collaborators have endorsed the project. Some companies have been purchased and consolidated, but all of the original collaborators are still behind the project and PI has received good feed back from the collaborators. Co-chair indicted that there are wide interests in the research with most industrial companies.

The major scientific insight that will result from the research will be in determining the relationships between biological mechanisms and growth enhancements. This could be a relationship that applies to other tree species and other plant species. A paper in the latest quarterly report addresses the scientific insights from the research.

Improving the efficiency of nutrient utilization will require less nutrients per unit of growth and can reduce the amount of fertilizers needed. Increased growth will also aid in carbon sequestration.

According to the $\mathrm{PI}$, no new major technologies are anticipated from the research.

Understanding nutrition requirements can make existing technologies more efficient.

This research does not apply to recycled wood and paper.

When data is published on expected yield increases from proper timing for competition control and fertilization, then a more accurate risk/benefit analysis can be made. The potential for substantially improved growth rates in plantation timber makes the speculative risk seem small considering the approximately $\$ 250,000$ research investment. Co-chair thought that this project progressed well with good results and deserved a high ranking overall.

Although the research could lead to increased quantities of biomass, the research does not address alternative uses for biomass. 
FOREST PRODUCTS INDUSTRY OF THE FUTURE - PORTFOLIO STUDY AND EVALUATION

16-677 Model-Based Diagnosis of Soil Limitations

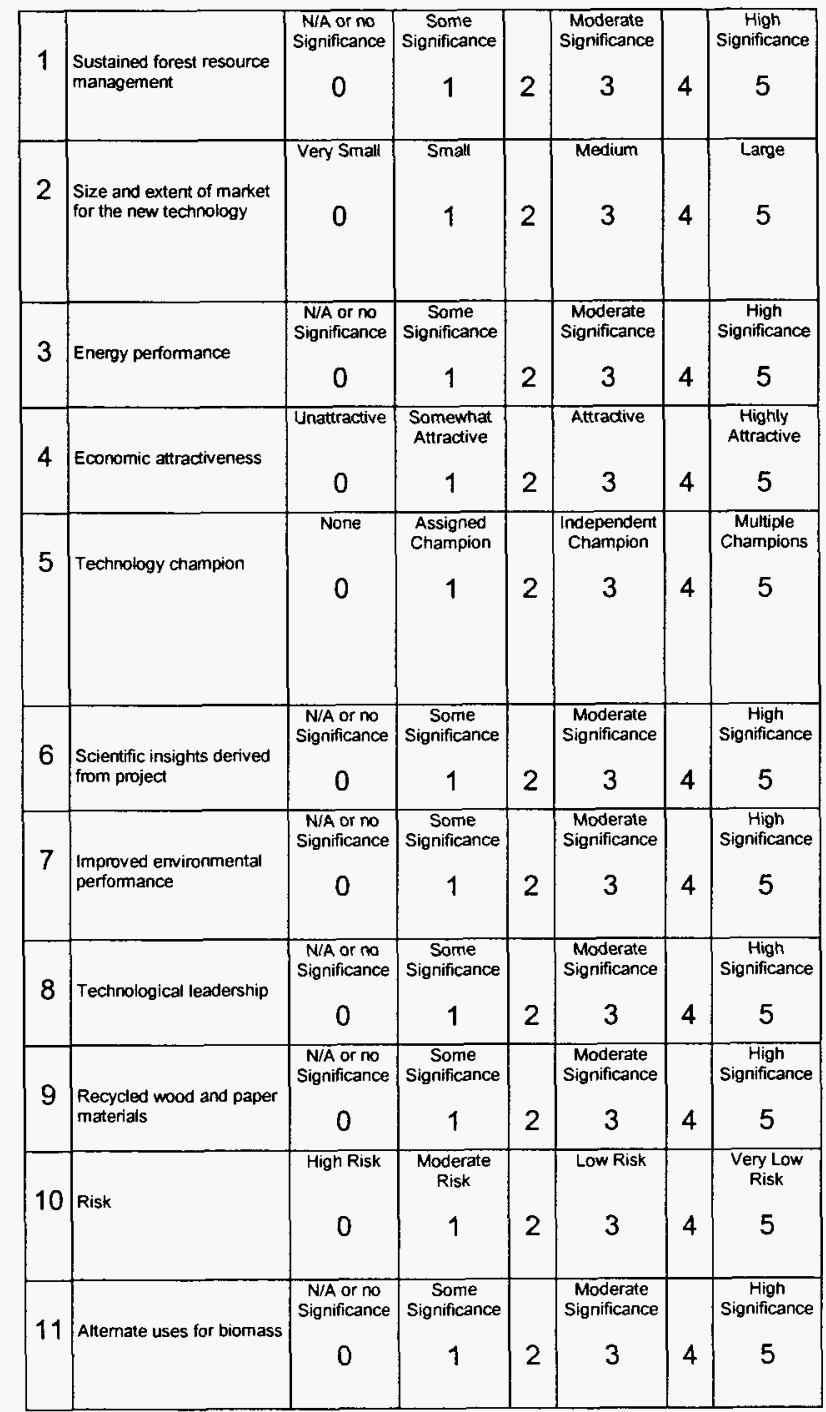

Totals

\begin{tabular}{|c|c|c|}
\hline $\begin{array}{c}\text { CTO } \\
\text { Weighting }\end{array}$ & $\begin{array}{l}\text { Raw } \\
\text { Rating }\end{array}$ & $\begin{array}{c}\text { Weighted } \\
\text { Rating }\end{array}$ \\
\hline 10 & 4 & 40 \\
\hline $\begin{array}{c}\text { CTO } \\
\text { Weighting }\end{array}$ & $\begin{array}{c}\text { Raw } \\
\text { Rating }\end{array}$ & $\begin{array}{c}\text { Weighted } \\
\text { Rating }\end{array}$ \\
\hline 9 & 3 & 27 \\
\hline \begin{tabular}{|c|c|c|} 
CTO \\
Weighting
\end{tabular} & $\begin{array}{c}\text { Raw } \\
\text { Rating }\end{array}$ & $\begin{array}{l}\text { Weighted } \\
\text { Rating }\end{array}$ \\
\hline 8 & 2 & 16 \\
\hline \begin{tabular}{|c|} 
CTO \\
Weighting
\end{tabular} & $\begin{array}{c}\text { Raw } \\
\text { Rating }\end{array}$ & $\begin{array}{c}\text { Weighted } \\
\text { Rating }\end{array}$ \\
\hline 8 & 3 & 24 \\
\hline \begin{tabular}{|l} 
CTO \\
Weighting
\end{tabular} & $\begin{array}{c}\text { Raw } \\
\text { Rating }\end{array}$ & $\begin{array}{c}\text { Weighted } \\
\text { Rating }\end{array}$ \\
\hline 7 & 3 & 21 \\
\hline \begin{tabular}{|c|c|c|c|c|} 
CTO \\
\end{tabular} & $\begin{array}{c}\text { Raw } \\
\text { Rating }\end{array}$ & $\begin{array}{c}\text { Weighted } \\
\text { Rating }\end{array}$ \\
\hline 7 & 2 & 14 \\
\hline $\begin{array}{c}\text { CTO } \\
\text { Weighting }\end{array}$ & $\begin{array}{c}\text { Raw } \\
\text { Rating }\end{array}$ & $\begin{array}{c}\text { Weighted } \\
\text { Rating }\end{array}$ \\
\hline 7 & 3 & 21 \\
\hline $\begin{array}{c}\text { CTO } \\
\text { Weighting }\end{array}$ & $\begin{array}{c}\text { Raw } \\
\text { Rating }\end{array}$ & $\begin{array}{c}\text { Weighted } \\
\text { Rating }\end{array}$ \\
\hline 7 & 3 & 21 \\
\hline $\begin{array}{c}\text { CTO } \\
\text { Weighting }\end{array}$ & $\begin{array}{c}\text { Raw } \\
\text { Rating }\end{array}$ & $\begin{array}{l}\text { Weighted } \\
\text { Rating }\end{array}$ \\
\hline 6 & 0 & 0 \\
\hline $\begin{array}{c}\text { CTO } \\
\text { Weighting }\end{array}$ & $\begin{array}{c}\text { Raw } \\
\text { Rating }\end{array}$ & $\begin{array}{l}\text { Weighted } \\
\text { Rating }\end{array}$ \\
\hline 6 & 5 & 30 \\
\hline $\begin{array}{c}\text { CTO } \\
\text { Weighting }\end{array}$ & $\begin{array}{c}\text { Raw } \\
\text { Rating }\end{array}$ & $\begin{array}{c}\text { Welghted } \\
\text { Rating }\end{array}$ \\
\hline 5 & 2 & 10 \\
\hline
\end{tabular}

30

\section{Comments}

The benefits to sustained resource management from the research will be in being able to model nutrient utilization and soil limitations and thus implement activities to reduce soil limitations to tree growth. This will increase the yield of fiber from a given land base through more productivity.

The two primary models that are being developed are for Loblolly pine and Douglas fir. These two species constitute a large percentage of industrial forest plantations. Decision guidance models will be made available via the world wide web so access to the research will be readily available to timberland owners. The usefulness and the applicability of the models to a large audience may be limited.

Increases in fiber production could make more biomass available as a fuel source.

Increasing nutrient utilization efficiency could result in more efficient utilization of fertilizers, which will make the fertilization process more energy efficient.

The ability to increase site productivity and enhance the efficient utilization of fertilizers in loblolly pine and Douglas fir could produce appealing economic benefits for timber producers

There are four sub-recipient institutions, (Desert Research Institute, Texas A\&M, University of New Hampshire, University of Washington), four industry collaborators (International Paper, The Timber Company, Potlatch, and Weyerhaeuser), and the North Carolina State University Forest Nutrition Cooperative that are involved in the research. According to the PI, there is widespread support for the research. According to the co-chair, industry support is not very strong.

This research could lay the groundwork for additional research and advancements in site preparation and fertilizer formulation technologies. However, much of the research, according to the co-chair, is based on existing climate and soils data.

Increased productivity resulting from more efficient utilization of nutrients can result in less land base required to meet productivity requirements. Higher plant growth rates result in more carbon sequestration. More efficient uptake of nutrients could also result in less nutrient leaching and runoff.

PI indicated that this research was leading edge in this area and that it was much needed to understand the relationships of trees and nutrient utilization. Co-chair stated that some good results were generated early on but that project currently needs direction.

This research is not specifically related to recycling.

The potential benefits that could result from this and future related research projects are quite substantial compared to the developmental risks. Co-chair suggested that this research might be able to be tied-in with the module for the effects of fertilization and competition control

Although the project does not specifically address alternative uses for biomass, it does address issues that could enhance the production of biomass. Co-chair suggested that this research might be able to be tied-in with the module for the effects of fertilization and competition control. 
17-681 Marker-Aided Selection Methods

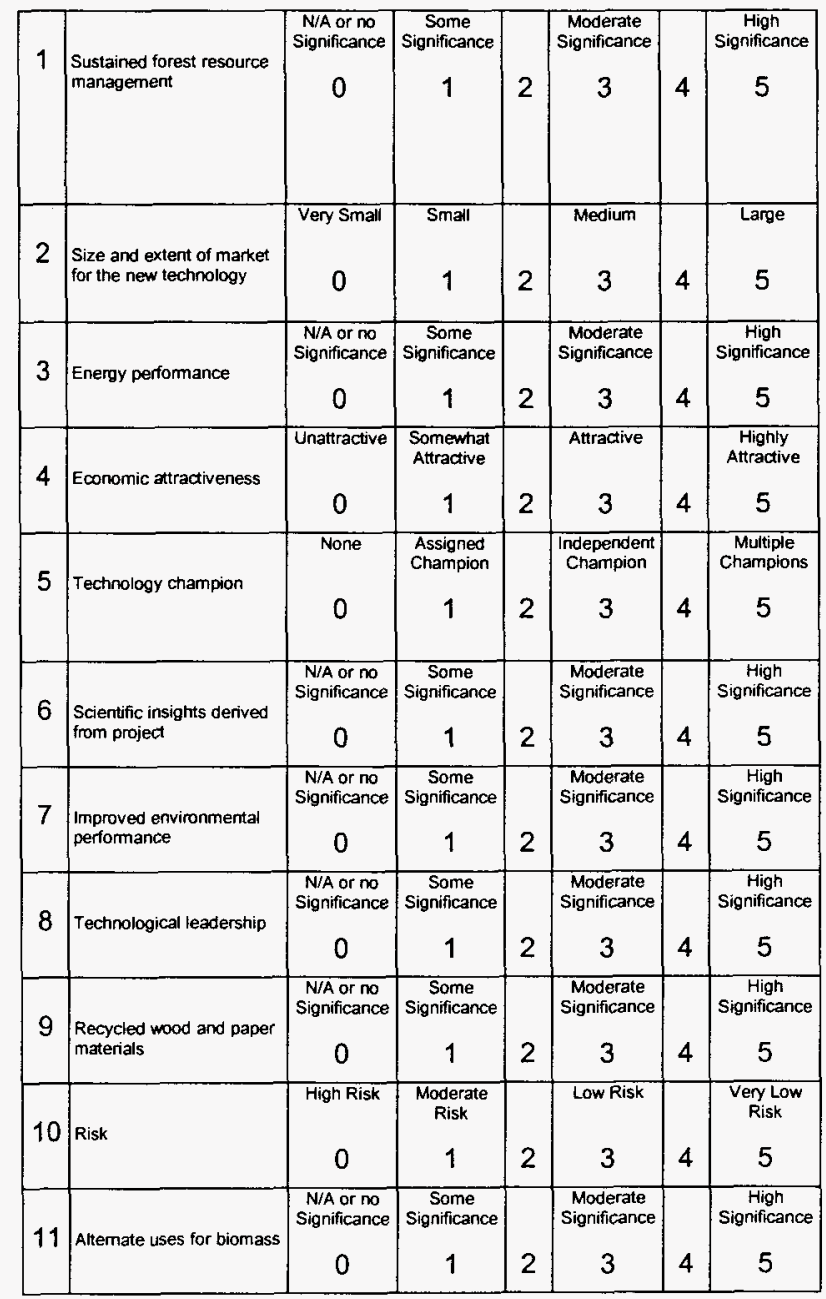

Totals

\section{Comments}

The ultimate impact of the research will be mostly process related in the pulp industry with manipulation of cellulose and lignin allocation within trees. This will result in higher yields and less inputs to the process. Ultimately, the results will be more useable fiber from the given land base. From a fiber quality standpoint, the microfibal angle in wood can be linked to certain genes. Modifying traits could allow wood quality properties to be improved as well. End result... more useable, higher quality fiber from a given land base.

This particular research was geared more towards pulp and paper and bio-fuels. The research is foundational in nature to other research that could lead to much larger market impacts.

As reported with the nitrogen allocation project (OTIS 758) this research could lead to substantial shifting of cellulose/lignin allocation within trees which could be beneficial from an energy standpoint to pulping, bleaching, and bio-fuel production.

PI had not performed any economic analysis on the project. The potential for yield increases both in the forest and at the mill provide the basis for an attractive scenario to industry for developing transgenic trees that utilize some of the knowledge gained from the research. The University of Washington was a collaborator on the project as well as the US Forest Service. Boise Cascade and Weyerhaeuser were industry collaborators. All participants were involved from beginning to end. Weyerhaeuser and USFS seemed to show the most interest in the project. University of Washington worked to develop a genetic map.

$\mathrm{PI}$ believes that this research could be beneficial to other researchers as they study different species. Information is already being requested from other researchers as they are involved in new studies.

PI reported that implementation of the research findings in the pulping process for this particular research could result in a $10 \%$ reduction in chemical use for fiber from transgenic its could also result from research stimulated from these research findings. PI felt that this research was leading edge research in the area of identifying the function of specific genes in trees.

\section{This research did not specifically address recycling}

The potential benefits directly from this research as well as future discoveries that may be derived from this research are estimated to be relatively high compared to the research investment.

This research could lead to methods for producing bio-mass with greater fuel properties. 
FOREST PRODUCTS INDUSTRY OF THE FUTURE - PORTFOLIO STUDY AND EVALUATION

18-758 Molecular Physiology Allocation in Poplar

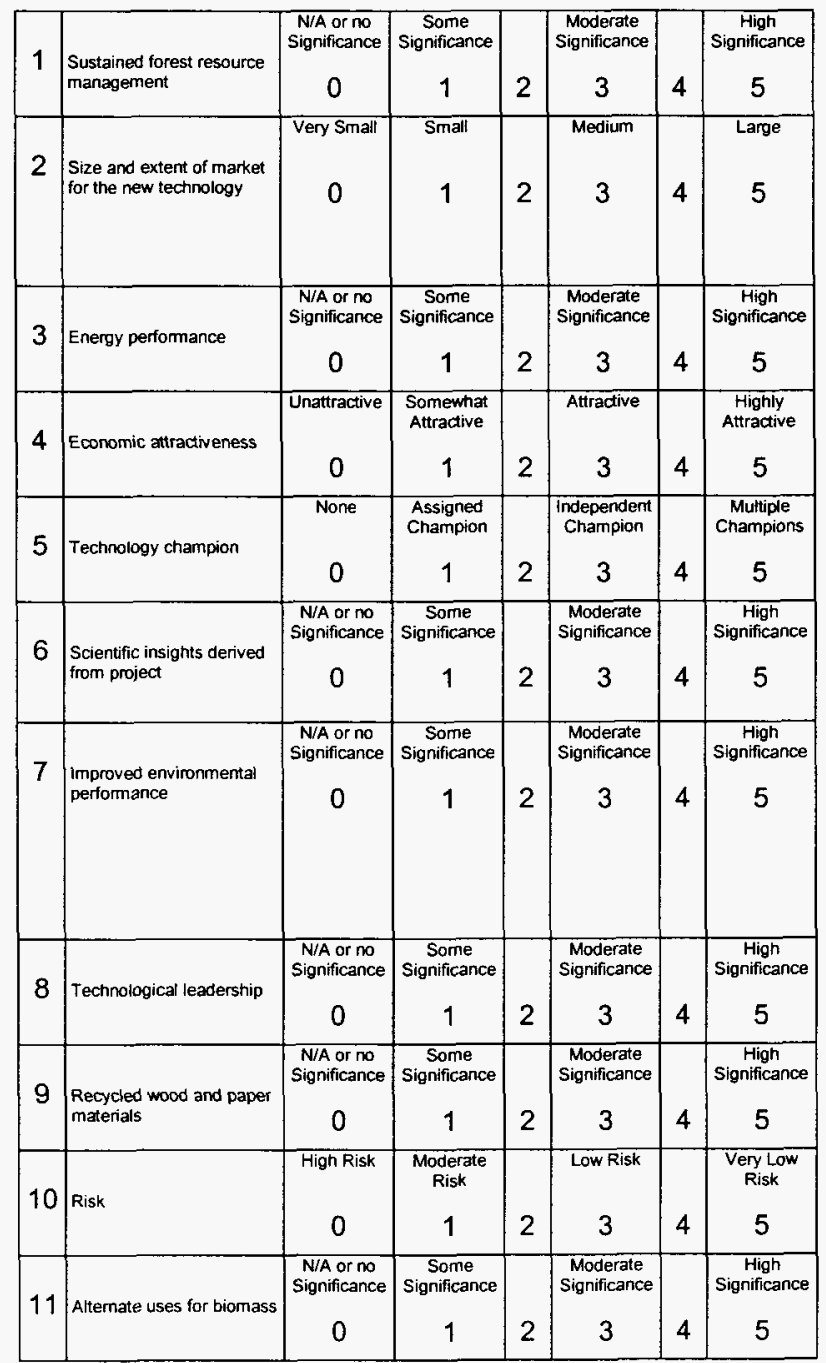

Totals

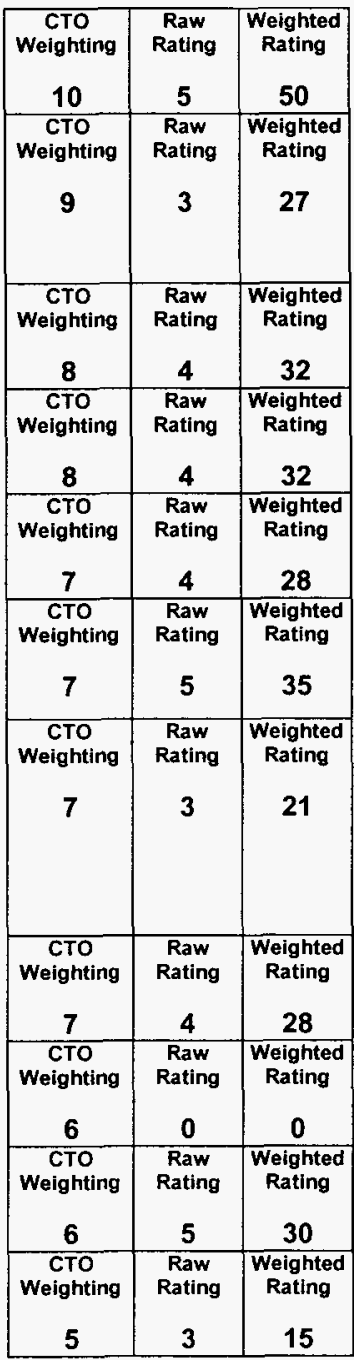

The driving benefit to sustained resource management is in being able to produce higher yields or shorter rotations for a given unit of land as the result of more efficient utilization of nutrients through transgenic trees. Opportunity aiso
improve or design wood qualities through genetic manipulation of carbon allocation to either cellulose or lignin.

Research was performed on hybrid poplars because they are relatively easier to genetically manipulate than species from the pine family. Poplars are npanan species that are subject lo sudden doses of nitrogen through nooding. Poplar leaves

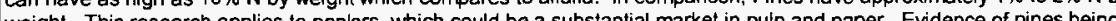
weight. This research applies to poplars, which could be a substana ces in pulp as paper. Evidence or ps is being International Paper will develop the transgenic poplar specie and pine research should follow although not a part of this project.

Creating nitrogen fertilizer (Urea) requires great amounts of energy ( 30,200 BTU/LB) and typical historical application rates are approximately $200 \mathrm{LB} / \mathrm{Acre}$. New application rates could be as low as $100 \mathrm{LB}$ Acre, which could decrease energy use for $N$ production by

PI reported that average pulp mill uses 4.7MMBTU/Ton for pulping and 7.5 MMBTU/Ton for bleaching. Estimates for energy 1/100\% of US raw materials from transgenic trees there could be a 6.6 billion BTU/year energy savings.

International Paper (Union Camp) was the original industry collaborator. Washington State University was a sub-recipient on the project and their task was to perform a field trial on the transgenic trees developed by Union Camp. It was determined that the Union Camp trees were not transgenic and the WSU work was not needed. Daniel Caraway with International Paper has been a good industry contact and has helped with the project.

Biologists are interested in the question of fundamental allocation relationships in plants and this research has provided more information in that area. Carbon/nitrogen balance and productivity wilhin planis has attracted the attention of other scientist to this research. There is also widespread interest in zylem and vascular development that his research could provide some undarts standpoint of how plants adapt to certain environments.

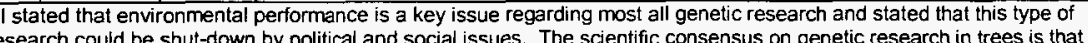
has no more risk than hybrid breeding but that caution should be taken. The goal of the research is to provide meaningfu alternatives that are subject to scrutiny before implementation. This particular genetic research has very litle negative

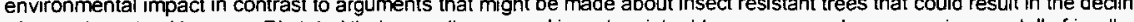
of some insects. However, PI stated that even disease and insect resistant trees were much more environmentally firendily tronger $\mathrm{CO} 2$ sinks. Poplars that act as stronger nitrogen sinks can be used as nitrogen barriers to protectrestore aqu and watersheds from nitrogen leaching. This could also help in preventing nitrogen leaching from organic fertlizers Bio-technology as a whole has high probability for producing breakthrough technologies. This research has discovered new genes and has prompted work on gene expression arrays. PI feels like that this research is on the leading edge of forestry research and is al least par win oher biological research. He feels like a good indeach is on his is ine qually or graduat

This research does not apply to recyded wood and paper.

Altough the total benefis to industry resulting from this research have not been quantified, the magnitude of the total

potential benefits would appear to be quite large.

The cellulosenignin work could provide for better ethanol processes. Being able to shift more lignin production to bark could also create new, more valuable markets for bark. For example, PI referred to one
from bark and using the resins to glue the bark back together as a panel product. 
FOREST PRODUCTS INDUSTRY OF THE FUTURE - PORTFOLIO STUDY AND EVALUATION

19-794 Dominant Negative Mutations of Floral Homeotic Genes

\begin{tabular}{|c|c|c|c|c|c|c|c|}
\hline 1 & $\begin{array}{l}\text { Sustained forest resource } \\
\text { management }\end{array}$ & \begin{tabular}{|c|} 
N/A or no \\
Significance \\
0 \\
\end{tabular} & \begin{tabular}{|c|} 
Some \\
Significance \\
1
\end{tabular} & & \begin{tabular}{|c|} 
Moderate \\
Signficance \\
3 \\
\end{tabular} & 4 & $\begin{array}{c}\text { High } \\
\text { Significance } \\
5\end{array}$ \\
\hline 2 & $\begin{array}{l}\text { Size and extent of market } \\
\text { for the new technology }\end{array}$ & $\begin{array}{c}\text { Very Small } \\
0\end{array}$ & $\begin{array}{c}\text { Smali } \\
1\end{array}$ & 2 & $\begin{array}{c}\text { Medium } \\
3 \\
3\end{array}$ & 4 & $\begin{array}{l}\text { Large } \\
5\end{array}$ \\
\hline 3 & Energy perfornance & $\begin{array}{c}\text { N/A or no } \\
\text { Significance } \\
0 \\
0\end{array}$ & \begin{tabular}{|c|} 
Some \\
significance \\
1
\end{tabular} & 2 & \begin{tabular}{|c|} 
Moderate \\
Significance \\
3 \\
\end{tabular} & 4 & $\begin{array}{c}\text { High } \\
\text { Significance } \\
5 \\
5\end{array}$ \\
\hline 4 & Economic attradiveness & $\begin{array}{c}\text { Unattractive } \\
0\end{array}$ & \begin{tabular}{|c|} 
Somewhat \\
Attractive \\
1
\end{tabular} & 2 & $\begin{array}{c}\text { Atractive } \\
3\end{array}$ & 4 & $\begin{array}{c}\text { Highty } \\
\text { Atradive } \\
5 \\
5\end{array}$ \\
\hline 5 & Techrology champion & $\begin{array}{c}\text { None } \\
0\end{array}$ & \begin{tabular}{|c|} 
Assigned \\
Champion \\
1
\end{tabular} & 2 & $\begin{array}{c}\begin{array}{c}\text { Independent } \\
\text { Champion } \\
3\end{array} \\
\end{array}$ & 4 & \begin{tabular}{|c|c|} 
Multipie \\
Champions \\
5 \\
5
\end{tabular} \\
\hline 6 & \begin{tabular}{|l} 
Scientific insights derived \\
from project
\end{tabular} & \begin{tabular}{|c|} 
N/A or no \\
Significance \\
0 \\
0
\end{tabular} & \begin{tabular}{|c|} 
Some \\
significance \\
1
\end{tabular} & 2 & $\begin{array}{c}\begin{array}{c}\text { Moderate } \\
\text { Signiificance } \\
3\end{array} \\
3\end{array}$ & 4 & $\begin{array}{c}\text { High } \\
\text { Significance } \\
5 \\
5\end{array}$ \\
\hline 7 & $\begin{array}{l}\text { Improved environmental } \\
\text { performance }\end{array}$ & \begin{tabular}{|c} 
N/A or no \\
Significance \\
0
\end{tabular} & $\begin{array}{c}\text { Some } \\
\text { Significance } \\
1 \\
1\end{array}$ & 2 & \begin{tabular}{|c|} 
Moderate \\
Significance \\
3 \\
\end{tabular} & 4 & 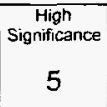 \\
\hline 8 & Technological leadership & $\begin{array}{c}\text { N/A or no } \\
\text { Significance } \\
0\end{array}$ & \begin{tabular}{|c|} 
Some \\
Significance \\
1
\end{tabular} & 2 & \begin{tabular}{|c|} 
Moderate \\
Significance \\
3 \\
\end{tabular} & 4 & $\begin{array}{c}\text { High } \\
\text { Significance } \\
5 \\
5\end{array}$ \\
\hline 9 & $\begin{array}{l}\text { Recycled wood and paper } \\
\text { materials }\end{array}$ & $\begin{array}{c}\text { N/A or no } \\
\text { Significance } \\
0\end{array}$ & \begin{tabular}{|c} 
Some \\
signficance \\
1
\end{tabular} & 2 & \begin{tabular}{|c|} 
Moderate \\
Significance \\
3 \\
\end{tabular} & 4 & $\begin{array}{c}\text { High } \\
\text { Significance } \\
5 \\
5\end{array}$ \\
\hline 10 & Risk & $\begin{array}{c}\text { High Risk } \\
0\end{array}$ & $\begin{array}{c}\text { Moderate } \\
\text { Risk } \\
1\end{array}$ & 2 & $\begin{array}{c}\text { Low Risk } \\
3\end{array}$ & 4 & \begin{tabular}{|c|}
$\begin{array}{c}\text { Very Low } \\
\text { Risk } \\
5\end{array}$ \\
\end{tabular} \\
\hline 11 & Atremate uses for biomass & \begin{tabular}{|c|} 
N/A or no \\
Significance \\
0 \\
0
\end{tabular} & \begin{tabular}{|c} 
Some \\
Significance \\
1
\end{tabular} & 2 & $\begin{array}{c}\text { Moderate } \\
\text { Significance } \\
3\end{array}$ & 4 & $\begin{array}{c}\text { High } \\
\text { Significance } \\
5 \\
5\end{array}$ \\
\hline
\end{tabular}

Totals

\section{Comments}

Eventually, the ability to utilize the sustained resource benefits of transgenic trees could hinge on the ability to genetically engineer sterility into the trees. From the social and political standpoint of enabling the use of transgenic trees, the potential impact to sustained resource management from this research is huge From a physiological standpoint, flowering and reproduction requires large amounts of carbohydrates. Genetically engineering sterility into trees could free more carbohydrates for merchantabie fiber production This research is being conducted on poplars. The process and methodology used to develop sterility in poplars can crossover into developing sterility in other angiosperms as well as provide a basis for the process in developing sterility in gymmosperms. The exact methodology wil probably be linited to close species. The development of sterility in transgenic trees will ultimately influence a potentially huge market. As with sustainable management, sterility can be an enabling technology to improve energy for transgenic trees that can be designed to have better pulping qualities or more energy content.

The economic attractiveness of the research is high because it is an enabling technology that may allow future advances and applications of genetically engineered trees.

The research has several industrial collaborators... Alberta Pacific, Boise Cascade, International Paper, Potlatch, The Timber Company, Westvaco. Weyerhaeuser, and Aircruise Cellulose. PI reported that feedback has been good from collaborators. Co-chair stated that this research is very important to industry and it can have immediate impacts on applied technology.

In order to speed the testing in the lab, the researchers have made advancements in promoting early flowering in the research plants. PI reported that this advancement is useful in the lab but it is inadequate the early flowering. Co-chair indicated that the early flowering was a significant development.

The driving force behind this research is to improve environmental performance of intensively managed plantations by genetically engineering sterility into transgenic trees to prohibit "genetic pollution" through pollen spread from transenics. Although this technology has environmental benefits, its transgenics are developed. Some would argue that developing transgenics is an environmental risk.

$\mathrm{PI}$ believes that this research is leading edge in the areas of trees and in other areas of plant study.

Researchers are discovering phenomena that are not evident in annuals. Researchers in other areas have indicated interest in this research.

This project does not specifically address recycling.

Considering that the future of implementing transgenics into production could be directly related to the ability to produce sterile trees, the potential benefits of this research are great versus the cost of the research.

This research does not specifically address alternative uses for biomass but it could have a big impact on the ability to utilize transgenic trees that are designed to be higher in lignin (fuel) content 


\section{FOREST PRODUCTS INDUSTRY OF THE FUTURE - PORTFOLIO STUDY AND EVALUATION}

\section{0-795 Pine Gene Discovery Project}

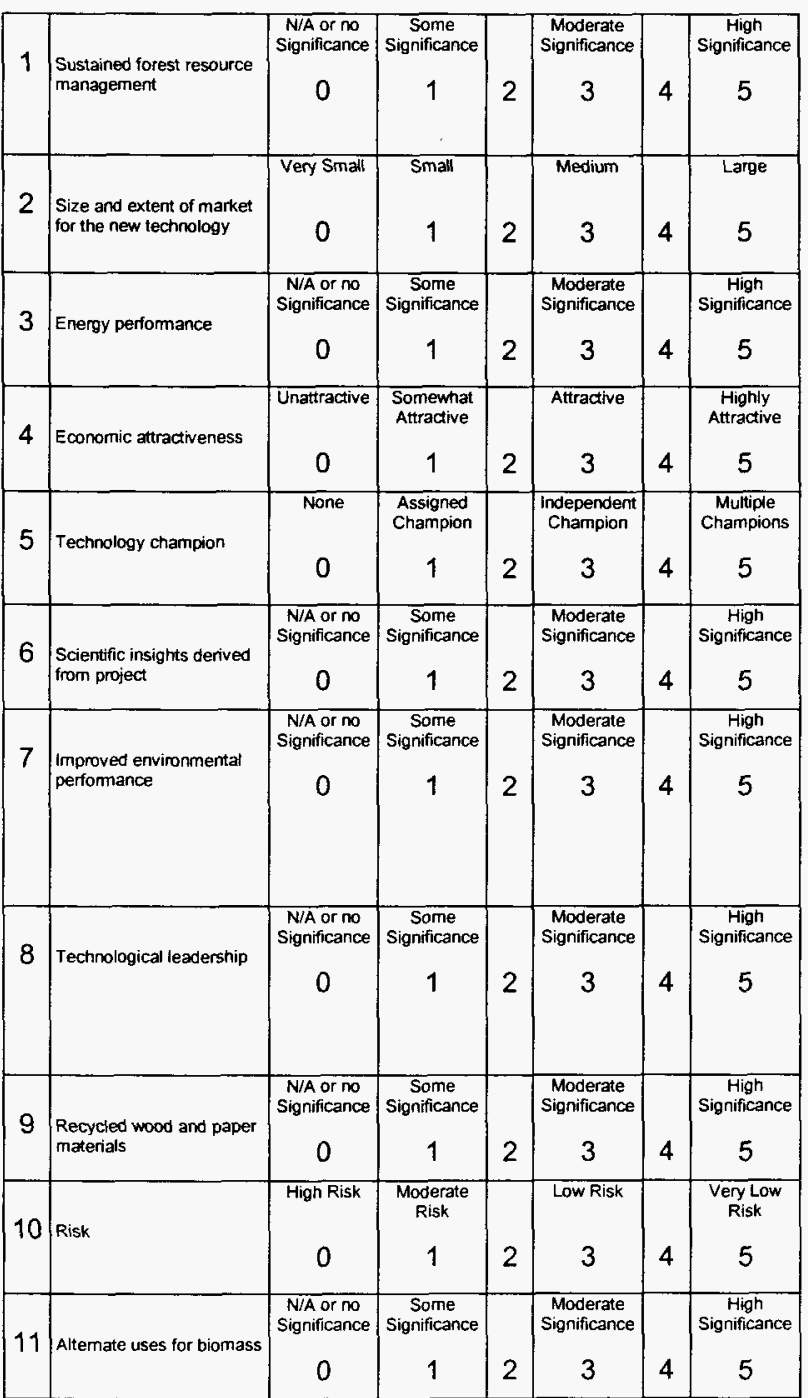

Totals

\begin{tabular}{|c|c|c|}
\hline $\begin{array}{c}\text { CTO } \\
\text { Weighting }\end{array}$ & $\begin{array}{l}\text { Raw } \\
\text { Rating }\end{array}$ & \begin{tabular}{|c} 
Weighted \\
Rating
\end{tabular} \\
\hline 10 & 5 & 50 \\
\hline $\begin{array}{c}\text { CTO } \\
\text { Weighting }\end{array}$ & $\begin{array}{c}\text { Raw } \\
\text { Rating }\end{array}$ & $\begin{array}{l}\text { Welighted } \\
\text { Rating }\end{array}$ \\
\hline 9 & 4 & 36 \\
\hline $\begin{array}{c}\text { cTo } \\
\text { Weighting }\end{array}$ & $\begin{array}{c}\text { Raw } \\
\text { Rating }\end{array}$ & $\begin{array}{c}\text { Weighted } \\
\text { Rating }\end{array}$ \\
\hline 8 & 3 & 24 \\
\hline $\begin{array}{c}\text { CTO } \\
\text { Weighting }\end{array}$ & $\begin{array}{c}\text { Raw } \\
\text { Rating }\end{array}$ & \begin{tabular}{|c} 
Weighted \\
Rating
\end{tabular} \\
\hline 8 & 3 & 24 \\
\hline $\begin{array}{c}\text { CTO } \\
\text { Weighting }\end{array}$ & $\begin{array}{c}\text { Raw } \\
\text { Rating }\end{array}$ & $\begin{array}{c}\text { Weighted } \\
\text { Rating }\end{array}$ \\
\hline 7 & 5 & 35 \\
\hline $\begin{array}{c}\text { CTO } \\
\text { Weighting }\end{array}$ & $\begin{array}{c}\text { Raw } \\
\text { Rating }\end{array}$ & \begin{tabular}{|c|} 
Weighted \\
Rating
\end{tabular} \\
\hline 7 & 5 & 35 \\
\hline $\begin{array}{c}\text { cTo } \\
\text { Weighting }\end{array}$ & $\begin{array}{c}\text { Raw } \\
\text { Rating }\end{array}$ & \begin{tabular}{|c} 
Weighted \\
Rating
\end{tabular} \\
\hline 7 & 3 & 21 \\
\hline \begin{tabular}{|c|c|c|c|} 
CTO \\
Weighting
\end{tabular} & $\begin{array}{c}\text { Raw } \\
\text { Rating }\end{array}$ & \begin{tabular}{|c} 
Weighted \\
Rating
\end{tabular} \\
\hline 7 & 4 & 28 \\
\hline \begin{tabular}{|c} 
cro \\
Weighting
\end{tabular} & $\begin{array}{c}\text { Raw } \\
\text { Rating }\end{array}$ & $\begin{array}{l}\text { Weighted } \\
\text { Rating }\end{array}$ \\
\hline 6 & 0 & 0 \\
\hline \begin{tabular}{|c|c|} 
Cro \\
Weighting
\end{tabular} & $\begin{array}{c}\text { Raw } \\
\text { Rating }\end{array}$ & $\begin{array}{c}\text { Weighted } \\
\text { Rating }\end{array}$ \\
\hline 6 & 5 & 30 \\
\hline $\begin{array}{c}\text { CTO } \\
\text { Weighting }\end{array}$ & $\begin{array}{c}\text { Raw } \\
\text { Rating }\end{array}$ & $\begin{array}{c}\text { Weighted } \\
\text { Rating }\end{array}$ \\
\hline 5 & 4 & 20 \\
\hline
\end{tabular}

dentifying the genes of loblolly is foundational to learning how all of the genes work in a tree. From this research it will be possible to understand and maniputte productivity in plantations and to understand productivity in natural forests. This is also foundational to producing trees with better quality. The mplications of benefits to sustainable resource management from research that will build from the discovery of pine genes is enormous.

This research could eventually have an influence on the entire wood products market worldwide. Fuel wood makes-up over one-half of the world's wood fiber use. Developing transgenic trees with higher fuel values could also greatly affect this market. Although this specific technology might not have a large market, it is an enabler to other technologies with huge markets.

In a broad scale, this research could lead to ways to improve energy utilization from trees as a

fermentation source (cellulose) as well as a direct energy source (lignin). Methods for increased vields and utilization, better pulping and bleaching qualities and various other energy saving benefits could build from this research

This research lays the foundation for a whole list of new developments that would be very economically attractive.

Four industry collaborators (G-P, Rayonier, International Paper, and Westvaco) were initially involved in the research and the researchers continue to interact with representatives from all four collaborators in addition to the original collaborators, companies from New Zealand, Japan, England, Portugal, and Brazl have expressed interest in the research.

Research in genetics is growing and the gene catalogue is a fundamental element of the research Through the DOE project, the PI stated that one of the most valuable insights learned was not scientific but was in how to manage this type of research project with multiple researchers in different locations.

PI stated that the environmental risks associated with transgenic trees are greatly overstated. This research promotes an increasing rate of domestication in trees similar to what has been done in

agricultural crops. As with agricultural crops, specialized trees cannot survive in a competifive environment outside the controls of the plantation. From a scientific perspective, transgenic trees offer advantages in environmental performance i.e., insect resistant trees versus pesticides and bottom nutrient utilization However, there are scientific, political, and social issues mainly in the areas of bio-diversity and genetic "poliution" that pits transgenics against the environment

PI stated that this research team is the world leader in gene research in pines. Sweden leads in poplar gene research. New Zealand leads in Eucalyptus research and a new project is underway in Canada to perform gene research in spruce and poplar. Pl also stated that there is also another DOE project to sequence the entire genome in poplar. Using the genome of arabidopsis as a basis, poplar has 5 to 6 times more genes, the human genome contains 20 times more genes and the pine genome contains 200 times more genes. Co-chair was complimentary of research team.

This project does not address recycling directly. However, PI stated that recycling is inefficient, economically non-justifiable and could be eliminated through improvements with transgenic trees.

According to the PI environmental benefits associated with transgenic trees greatly outweigh the perceived environmental risks. This research is foundational, pathway type research that establishes the basis for a vast amount of new research and technologies. The research is essential to further research in tree genetics.

This research did not specifically address alternative uses for bio-mass but again, it lays the foundation for all kinds of future research to develop alternative uses for biomass 


\section{1-1481 Lateral Corrugator}

\begin{tabular}{|c|c|c|c|c|c|c|c|}
\hline 1 & $\begin{array}{l}\text { Sustained forest resource } \\
\text { management }\end{array}$ & \begin{tabular}{|c|} 
N/A or no \\
Significance \\
0 \\
\end{tabular} & \begin{tabular}{|c|} 
Some \\
Significance \\
1
\end{tabular} & 2 & \begin{tabular}{|c|} 
Moderate \\
Significance \\
3 \\
\end{tabular} & 4 & $\begin{array}{c}\text { High } \\
\text { Significance } \\
5\end{array}$ \\
\hline 2 & $\begin{array}{l}\text { Size and extent of market } \\
\text { for the new tecthology }\end{array}$ & \begin{tabular}{|c|} 
very Small \\
0
\end{tabular} & $\begin{array}{c}\text { Smail } \\
1\end{array}$ & 2 & $\begin{array}{c}\text { Medium } \\
3\end{array}$ & 4 & $\begin{array}{l}\text { Large } \\
5\end{array}$ \\
\hline 3 & Energy perfomance & \begin{tabular}{|c|} 
N/A or no \\
Significance \\
0
\end{tabular} & \begin{tabular}{|c|} 
Some \\
Significance \\
1 \\
\end{tabular} & 2 & \begin{tabular}{|c|} 
Moderate \\
Significance \\
3 \\
\end{tabular} & 4 & $\begin{array}{c}\text { High } \\
\text { Significance } \\
5\end{array}$ \\
\hline 4 & Economic attractiveness & \begin{tabular}{|c|} 
Unattractive \\
0 \\
0
\end{tabular} & $\begin{array}{c}\text { Somewhat } \\
\text { Atractive } \\
1\end{array}$ & 2 & $\begin{array}{c}\text { Attractive } \\
3\end{array}$ & 4 & $\begin{array}{c}\text { Highily } \\
\text { Attractive } \\
5\end{array}$ \\
\hline 5 & Technology champion & $\begin{array}{c}\text { None } \\
0\end{array}$ & \begin{tabular}{|c|} 
Assigned \\
Csampion \\
1
\end{tabular} & 2 & \begin{tabular}{|c|}
$\begin{array}{c}\text { Independent } \\
\text { Champion } \\
3\end{array}$ \\
\end{tabular} & 4 & $\begin{array}{c}\text { Muttiple } \\
\text { Champions } \\
5\end{array}$ \\
\hline 6 & 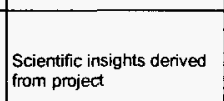 & \begin{tabular}{|c|} 
N/A o no \\
Significance \\
0 \\
\end{tabular} & $\begin{array}{c}\text { Some } \\
\text { Significance } \\
1\end{array}$ & 2 & \begin{tabular}{|c|} 
Moderate \\
Significance \\
3 \\
\end{tabular} & 4 & \begin{tabular}{|c|} 
High \\
Significance \\
5
\end{tabular} \\
\hline 7 & $\begin{array}{l}\text { Improved emwironmental } \\
\text { performance }\end{array}$ & \begin{tabular}{|c|} 
N/A or no \\
Significance \\
0 \\
\end{tabular} & $\begin{array}{c}\text { Some } \\
\text { significance } \\
1\end{array}$ & 2 & \begin{tabular}{|c|} 
Moderate \\
Significance \\
3 \\
\end{tabular} & 4 & $\begin{array}{c}\text { High } \\
\text { Significance } \\
5\end{array}$ \\
\hline 8 & Technological leadership & \begin{tabular}{|c|} 
N/A or no \\
Significance \\
0 \\
0
\end{tabular} & \begin{tabular}{|c|} 
Some \\
significance \\
1 \\
\end{tabular} & 2 & \begin{tabular}{|c|} 
Moderate \\
Significance \\
3 \\
\end{tabular} & 4 & \begin{tabular}{|c|} 
High \\
Significance \\
5 \\
5
\end{tabular} \\
\hline 9 & $\begin{array}{l}\text { Recycled wood and paper } \\
\text { materials }\end{array}$ & \begin{tabular}{|c|} 
NiA or no \\
Significance \\
0 \\
\end{tabular} & \begin{tabular}{|c|} 
Some \\
significance \\
1 \\
1
\end{tabular} & 2 & \begin{tabular}{|c|} 
Moderate \\
Significance \\
3 \\
\end{tabular} & 4 & $\begin{array}{c}\text { High } \\
\text { Significance } \\
5 \\
5\end{array}$ \\
\hline 10 & Risk & $\begin{array}{c}\text { High Risk } \\
0\end{array}$ & $\begin{array}{c}\text { Moderate } \\
\text { Risk } \\
1\end{array}$ & 2 & $\begin{array}{c}\text { Low Risk } \\
3\end{array}$ & 4 & $\begin{array}{c}\begin{array}{c}\text { Ven Low } \\
\text { Risk } \\
5\end{array} \\
\end{array}$ \\
\hline 11 & Altemate uses for biomass & \begin{tabular}{|c|} 
N/A or no \\
Significance \\
0 \\
\end{tabular} & \begin{tabular}{|c|} 
Some \\
Significance \\
1
\end{tabular} & 2 & \begin{tabular}{|c|} 
Moderate \\
Significance \\
3 \\
\end{tabular} & 4 & $\begin{array}{c}\text { High } \\
\text { Significance } \\
5\end{array}$ \\
\hline
\end{tabular}

Totals

\section{Comments}

\begin{tabular}{|c|c|c|}
\hline $\begin{array}{c}\text { CTO } \\
\text { Weighting } \\
10\end{array}$ & $\begin{array}{c}\text { Raw } \\
\text { Rating } \\
1\end{array}$ & \begin{tabular}{|c|}
$\begin{array}{c}\text { Weighted } \\
\text { Rating }\end{array}$ \\
10
\end{tabular} \\
\hline $\begin{array}{c}\text { CTO } \\
\text { Weighting }\end{array}$ & $\begin{array}{c}\text { Raw } \\
\text { Rating }\end{array}$ & $\begin{array}{c}\text { Weighted } \\
\text { Rating }\end{array}$ \\
\hline 9 & 2 & 18 \\
\hline $\begin{array}{c}\text { CTO } \\
\text { Weighting }\end{array}$ & $\begin{array}{l}\text { Raw } \\
\text { Rating }\end{array}$ & \begin{tabular}{|c|}
$\begin{array}{c}\text { Weighted } \\
\text { Rating }\end{array}$ \\
\end{tabular} \\
\hline 8 & 1 & 8 \\
\hline $\begin{array}{c}\text { CTO } \\
\text { Weighting }\end{array}$ & $\begin{array}{l}\text { Raw } \\
\text { Rating }\end{array}$ & $\begin{array}{c}\text { Weighted } \\
\text { Rating }\end{array}$ \\
\hline 8 & 1 & 8 \\
\hline $\begin{array}{c}\text { CTO } \\
\text { Weighting }\end{array}$ & $\begin{array}{l}\text { Raw } \\
\text { Rating }\end{array}$ & $\begin{array}{l}\text { Weighted } \\
\text { Rating }\end{array}$ \\
\hline 7 & 0 & 0 \\
\hline $\begin{array}{c}\text { CTO } \\
\text { Weighting }\end{array}$ & $\begin{array}{l}\text { Raw } \\
\text { Rating }\end{array}$ & $\begin{array}{c}\text { Weighted } \\
\text { Rating }\end{array}$ \\
\hline 7 & 1 & 7 \\
\hline $\begin{array}{c}\text { CTO } \\
\text { Weighting }\end{array}$ & $\begin{array}{l}\text { Raw } \\
\text { Rating }\end{array}$ & $\begin{array}{l}\text { Weighted } \\
\text { Rating }\end{array}$ \\
\hline 7 & 2 & 14 \\
\hline $\begin{array}{c}\text { CTO } \\
\text { Weighting }\end{array}$ & $\begin{array}{c}\text { Raw } \\
\text { Rating }\end{array}$ & $\begin{array}{c}\text { Weighted } \\
\text { Rating }\end{array}$ \\
\hline 7 & 2 & 14 \\
\hline $\begin{array}{c}\text { CTO } \\
\text { Weighting }\end{array}$ & $\begin{array}{l}\text { Raw } \\
\text { Rating }\end{array}$ & $\begin{array}{c}\text { Weighted } \\
\text { Rating }\end{array}$ \\
\hline 6 & 0 & 0 \\
\hline $\begin{array}{c}\text { CTO } \\
\text { Weighting }\end{array}$ & $\begin{array}{l}\text { Raw } \\
\text { Rating }\end{array}$ & $\begin{array}{c}\text { Weighted } \\
\text { Rating }\end{array}$ \\
\hline 6 & 1 & 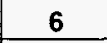 \\
\hline $\begin{array}{c}\text { CTO } \\
\text { Weighting }\end{array}$ & $\begin{array}{l}\text { Raw } \\
\text { Rating }\end{array}$ & $\begin{array}{c}\text { Weighted } \\
\text { Rating }\end{array}$ \\
\hline 5 & 0 & 0 \\
\hline
\end{tabular}

\begin{tabular}{|c|}
\hline $\begin{array}{l}\text { The new lateral corrugator is projected to use } 15 \% \text { less fiber to achieve the same strength } \\
\text { corrugated board. A } 15 \% \text { reduction is significant but the total production of corrugating } \\
\text { medium coupled with the limited market for new corrugating machines limits the relevance of } \\
\text { this project to sustainable forestry. } \\
\text { Market overcapacity in corrugating medium severely limits both the new machine market and } \\
\text { the replacement. }\end{array}$ \\
\hline Energy savings from producing fewer tons of corrugating medium (9.5 Mtons/yr.) \\
\hline $\begin{array}{l}\text { Market overcapacity in corrugating medium severely limits both the new machine market and } \\
\text { the replacement. }\end{array}$ \\
\hline None. Project has lost its corporate sponsor. \\
\hline $\begin{array}{l}\text { Knowledge of matching the strength properties of the paper with the construction design of } \\
\text { corrugated containers. }\end{array}$ \\
\hline $\begin{array}{l}\text { Assuming success in both research and commercialization, the corrugator would have minor } \\
\text { environmental impact because of reduced production and lowered tonnage of post-consumer } \\
\text { waste material. }\end{array}$ \\
\hline $\begin{array}{l}\text { Development of higher stacking strength corrugated containers with } 15 \% \text { less fiber } \\
\text { consumption. }\end{array}$ \\
\hline Not applicable. \\
\hline $\begin{array}{l}\text { Risks to the research success are technical problems of synchronous, high-speed material } \\
\text { handling. The likelihood of commercialization is poor because there is no "market pull" under } \\
\text { today's economy. }\end{array}$ \\
\hline Not Applicable. \\
\hline
\end{tabular}

\begin{tabular}{l|l|}
11 & 85 \\
\hline
\end{tabular} 
22-1482 Improved Dryer and Press Efficiencies

\begin{tabular}{|c|c|c|c|c|c|c|c|}
\hline 1 & $\begin{array}{l}\text { Sustained forest resource } \\
\text { management }\end{array}$ & \begin{tabular}{|c|} 
N/A or no \\
Significance \\
0 \\
0
\end{tabular} & \begin{tabular}{|c|} 
Some \\
Significance \\
1 \\
1
\end{tabular} & & \begin{tabular}{|c|} 
Moderate \\
Significance \\
3 \\
\end{tabular} & 4 & $\begin{array}{c}\begin{array}{c}\text { High } \\
\text { Significance } \\
5\end{array} \\
5\end{array}$ \\
\hline \multirow[b]{2}{*}{2} & & \begin{tabular}{|l|} 
Very Smail \\
\end{tabular} & Smail & & Medium & & Large \\
\hline & $\begin{array}{l}\text { Size and extent of market } \\
\text { for the new tectinology }\end{array}$ & 0 & 1 & 2 & 3 & 4 & 5 \\
\hline \multirow{2}{*}{3} & & \begin{tabular}{|l|} 
N/A or no \\
Significance
\end{tabular} & \begin{tabular}{|l|} 
Some \\
Significance
\end{tabular} & & \begin{tabular}{|l|} 
Moderate \\
Significance \\
\end{tabular} & & $\begin{array}{l}\text { High } \\
\text { Significance }\end{array}$ \\
\hline & Linergy pervinatine & 0 & 1 & 2 & 3 & 4 & 5 \\
\hline \multirow{2}{*}{4} & & \begin{tabular}{|l|} 
Unattractive \\
\end{tabular} & \begin{tabular}{|l|} 
Somewhat \\
Atractive
\end{tabular} & & \begin{tabular}{|l} 
Attractive \\
\end{tabular} & & $\begin{array}{c}\text { Highly } \\
\text { Attractive }\end{array}$ \\
\hline & 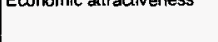 & 0 & 1 & 2 & 3 & 4 & 5 \\
\hline \multirow{2}{*}{5} & & & \begin{tabular}{|l|} 
Assigned \\
Champion
\end{tabular} & & $\begin{array}{c}\text { independent } \\
\text { Champion }\end{array}$ & & $\begin{array}{l}\text { Muttiple } \\
\text { Champions }\end{array}$ \\
\hline & 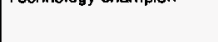 & 0 & 1 & 2 & 3 & 4 & 5 \\
\hline \multirow{2}{*}{6} & & \begin{tabular}{|l|} 
N/A or no \\
Significance
\end{tabular} & \begin{tabular}{|c|} 
Some \\
Significance \\
\end{tabular} & & \begin{tabular}{|l|l} 
Moderate \\
Significance \\
\end{tabular} & & $\begin{array}{l}\text { High } \\
\text { Significance }\end{array}$ \\
\hline & from pr & 0 & 1 & 2 & 3 & 4 & 5 \\
\hline \multirow{2}{*}{7} & & \begin{tabular}{|l|} 
N/A or no \\
Significance
\end{tabular} & \begin{tabular}{|c|} 
Some \\
Significance \\
\end{tabular} & & $\begin{array}{l}\text { Moderate } \\
\text { Significance }\end{array}$ & & $\begin{array}{c}\text { High } \\
\text { Significance }\end{array}$ \\
\hline & perfom & 0 & 1 & 2 & 3 & 4 & 5 \\
\hline \multirow{2}{*}{8} & Ter & \begin{tabular}{|c|} 
N/A or no \\
Significance
\end{tabular} & \begin{tabular}{|c|} 
Some \\
Significicance \\
\end{tabular} & & \begin{tabular}{|l|} 
Moderate \\
Significance \\
\end{tabular} & & $\begin{array}{c}\text { High } \\
\text { Significance }\end{array}$ \\
\hline & & 0 & 1 & 2 & 3 & 4 & 5 \\
\hline \multirow{2}{*}{9} & & \begin{tabular}{|c|} 
NA or no \\
Significance \\
\end{tabular} & \begin{tabular}{|c|} 
Some \\
Significance
\end{tabular} & & \begin{tabular}{|c|} 
Moderate \\
Significance
\end{tabular} & & $\begin{array}{l}\text { High } \\
\text { Significance }\end{array}$ \\
\hline & $\begin{array}{l}\text { leccyled wood and paper } \\
\text { materials }\end{array}$ & 0 & 1 & 2 & 3 & 4 & 5 \\
\hline \multirow{2}{*}{10} & & High Risk & $\begin{array}{c}\text { Moderate } \\
\text { Fisk }\end{array}$ & & Low Risk & & $\begin{array}{l}\text { Very Low } \\
\text { Risk }\end{array}$ \\
\hline & Jish & 0 & 1 & 2 & 3 & 4 & 5 \\
\hline \multirow{2}{*}{11} & \multirow{2}{*}{ Alternate uses for biomass } & \begin{tabular}{|c|} 
N/A or no \\
Significance
\end{tabular} & \begin{tabular}{|l|} 
Some \\
Significance
\end{tabular} & & \begin{tabular}{l|} 
Moderate \\
Significance \\
\end{tabular} & & $\begin{array}{l}\text { High } \\
\text { Significance }\end{array}$ \\
\hline & & 0 & 1 & 2 & 3 & 4 & 5 \\
\hline
\end{tabular}

Totals

\begin{tabular}{|c|c|c|}
\hline $\begin{array}{c}\text { Cro } \\
\text { Weighting }\end{array}$ & $\begin{array}{l}\text { Raw } \\
\text { Rating }\end{array}$ & $\begin{array}{c}\text { Weighted } \\
\text { Rating }\end{array}$ \\
\hline 10 & 0 & 0 \\
\hline $\begin{array}{c}\text { CTO } \\
\text { Weighting }\end{array}$ & $\begin{array}{l}\text { Raw } \\
\text { Rating }\end{array}$ & $\begin{array}{c}\text { Weighted } \\
\text { Rating }\end{array}$ \\
\hline 9 & 3 & 27 \\
\hline \begin{tabular}{|c|} 
CTO \\
Weighting
\end{tabular} & $\begin{array}{l}\text { Raw } \\
\text { Rating }\end{array}$ & $\begin{array}{c}\text { Weighted } \\
\text { Rating }\end{array}$ \\
\hline 8 & 4 & 32 \\
\hline $\begin{array}{c}\text { CTO } \\
\text { Weighting }\end{array}$ & $\begin{array}{l}\text { Raw } \\
\text { Rating }\end{array}$ & $\begin{array}{l}\text { Weighted } \\
\text { Rating }\end{array}$ \\
\hline 8 & 5 & 40 \\
\hline $\begin{array}{c}\text { CTO } \\
\text { Weighting }\end{array}$ & $\begin{array}{c}\text { Raw } \\
\text { Rating }\end{array}$ & $\begin{array}{c}\text { Weighted } \\
\text { Rating }\end{array}$ \\
\hline 7 & 4 & 28 \\
\hline $\begin{array}{c}\text { CTO } \\
\text { Weighting }\end{array}$ & $\begin{array}{c}\text { Raw } \\
\text { Rating }\end{array}$ & $\begin{array}{c}\text { Weighted } \\
\text { Rating }\end{array}$ \\
\hline 7 & 3 & 21 \\
\hline $\begin{array}{c}\text { Cro } \\
\text { Weighting }\end{array}$ & $\begin{array}{c}\text { Raw } \\
\text { Rating }\end{array}$ & $\begin{array}{l}\text { Weighted } \\
\text { Rating }\end{array}$ \\
\hline 7 & 4 & 28 \\
\hline $\begin{array}{c}\text { CTO } \\
\text { Weighting }\end{array}$ & $\begin{array}{l}\text { Raw } \\
\text { Rating }\end{array}$ & $\begin{array}{c}\text { Weighted } \\
\text { Rating }\end{array}$ \\
\hline 0 & 3 & 21 \\
\hline \begin{tabular}{|c|c|} 
CTO \\
Weighting
\end{tabular} & $\begin{array}{c}\text { Raw } \\
\text { Rating }\end{array}$ & $\begin{array}{c}\text { Weighted } \\
\text { Rating }\end{array}$ \\
\hline 6 & 0 & 0 \\
\hline \begin{tabular}{|c|c|} 
CTO \\
Weighting
\end{tabular} & $\begin{array}{c}\text { Raw } \\
\text { Rating }\end{array}$ & \begin{tabular}{|c} 
Weighted \\
Rating
\end{tabular} \\
\hline 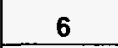 & 4 & 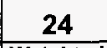 \\
\hline $\begin{array}{c}\text { CTO } \\
\text { Weighting }\end{array}$ & $\begin{array}{l}\text { Raw } \\
\text { Rating }\end{array}$ & $\begin{array}{c}\text { Weighted } \\
\text { Rating }\end{array}$ \\
\hline 5 & 0 & 0 \\
\hline
\end{tabular}

\begin{tabular}{l|l|}
\hline 30 & 221 \\
\hline
\end{tabular}

\section{Comments}

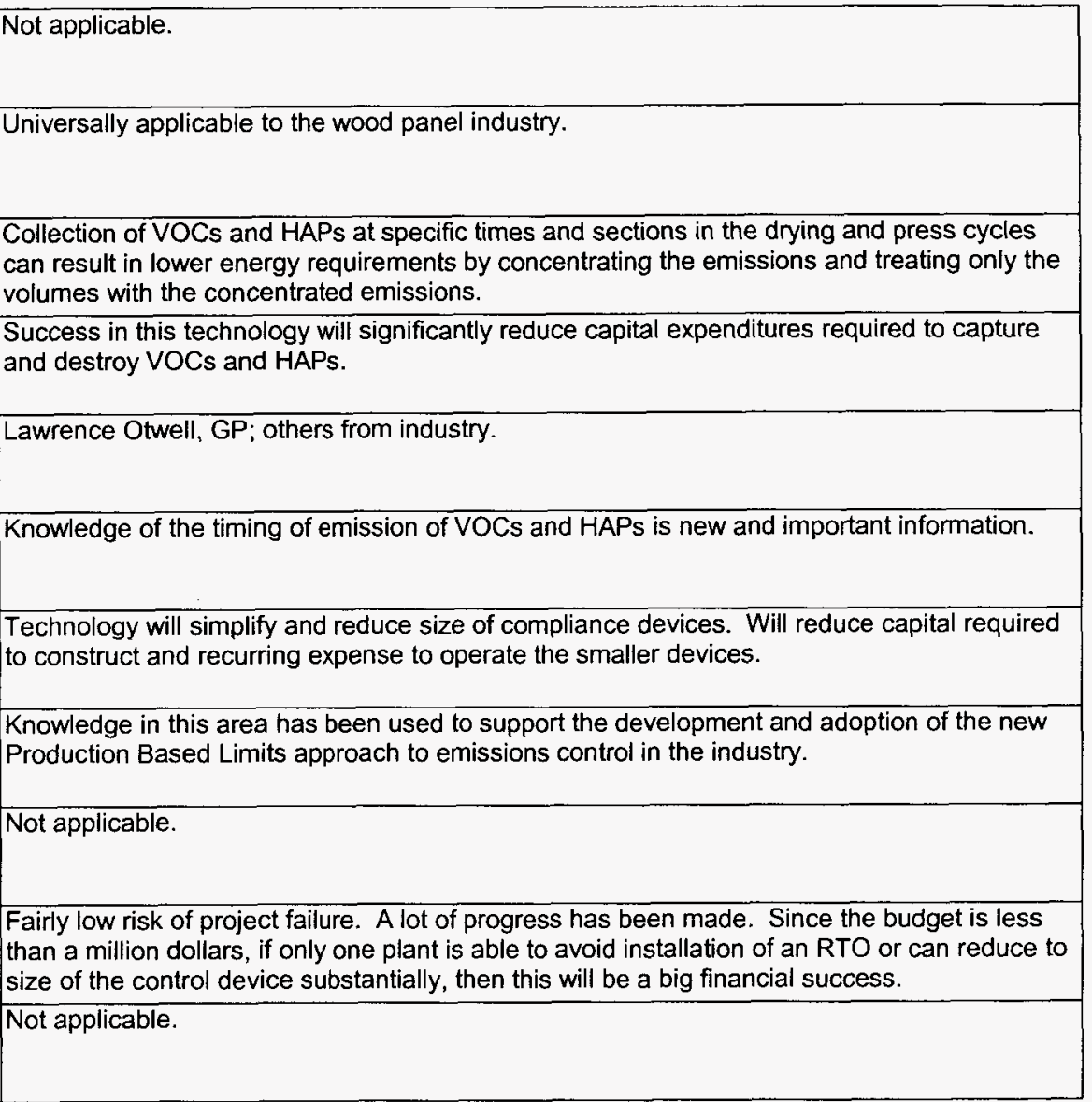


FOREST PRODUCTS INDUSTRY OF THE FUTURE - PORTFOLIO STUDY AND EVALUATION

\section{3-1483 Directed Green Liquor Pulping}

\begin{tabular}{|c|c|c|c|c|c|c|c|}
\hline 1 & $\begin{array}{l}\text { Sustained forest resources } \\
\text { management }\end{array}$ & $\begin{array}{c}\text { N/A or no } \\
\text { Significance } \\
0\end{array}$ & \begin{tabular}{|c|} 
Some \\
Significance \\
1 \\
\end{tabular} & 2 & $\begin{array}{c}\text { Moderate } \\
\text { Significance } \\
3\end{array}$ & 4 & $\begin{array}{c}\text { High } \\
\text { Significance } \\
5\end{array}$ \\
\hline \multirow[b]{2}{*}{2} & & Very Small & Small & & Medium & & $\begin{array}{l}\text { Lange } \\
\end{array}$ \\
\hline & $\begin{array}{l}\text { Size and extent of market } \\
\text { for the new technology }\end{array}$ & 0 & 1 & 2 & 3 & 4 & 5 \\
\hline \multirow{2}{*}{3} & F & $\begin{array}{l}\text { NA or no } \\
\text { Significance }\end{array}$ & \begin{tabular}{|c|} 
Some \\
Significance \\
\end{tabular} & & \begin{tabular}{l|} 
Moderate \\
Significance
\end{tabular} & & $\begin{array}{c}\text { High } \\
\text { Significance }\end{array}$ \\
\hline & Ennergy perromancee & 0 & 1 & 2 & 3 & 4 & 5 \\
\hline \multirow{2}{*}{4} & 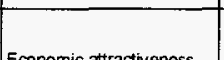 & & \begin{tabular}{|l|} 
Somewhat \\
Atradive
\end{tabular} & & Attractive & & $\begin{array}{l}\text { Highly } \\
\text { Atractive }\end{array}$ \\
\hline & f cconomic antraciveness & 0 & 1 & 2 & 3 & 4 & 5 \\
\hline \multirow{2}{*}{5} & Toch & & $\begin{array}{l}\text { Assigned } \\
\text { Champion }\end{array}$ & & $\begin{array}{l}\text { Independent } \\
\text { Champion }\end{array}$ & & $\begin{array}{l}\text { Multiple } \\
\text { champions }\end{array}$ \\
\hline & | Iecniology cnampion & 0 & 1 & 2 & 3 & 4 & 5 \\
\hline \multirow{2}{*}{6} & & $\begin{array}{l}\text { N/A or no } \\
\text { Signiificance }\end{array}$ & \begin{tabular}{|c|} 
Some \\
Significance
\end{tabular} & & $\begin{array}{l}\text { Moderate } \\
\text { Significance }\end{array}$ & & $\begin{array}{l}\text { High } \\
\text { Significance }\end{array}$ \\
\hline & $\begin{array}{l}\text { from pr } \\
\text { for }\end{array}$ & 0 & 1 & 2 & 3 & 4 & 5 \\
\hline \multirow{2}{*}{7} & & $\begin{array}{l}\text { N/A or no } \\
\text { Significance }\end{array}$ & \begin{tabular}{|c|} 
Some \\
Significance
\end{tabular} & & $\begin{array}{l}\text { Moderate } \\
\text { Signficance }\end{array}$ & & $\begin{array}{c}\text { High } \\
\text { Significance }\end{array}$ \\
\hline & perform & 0 & 1 & 2 & 3 & 4 & 5 \\
\hline \multirow{2}{*}{8} & $T$ & $\begin{array}{l}\text { N/A or no } \\
\text { Significance }\end{array}$ & $\begin{array}{c}\text { Some } \\
\text { Significance }\end{array}$ & & $\begin{array}{l}\text { Moderate } \\
\text { Significance }\end{array}$ & & $\begin{array}{l}\text { Hiligh } \\
\text { Significance }\end{array}$ \\
\hline & & 0 & 1 & 2 & 3 & 4 & 5 \\
\hline \multirow{2}{*}{9} & \multirow{2}{*}{$\begin{array}{l}\text { Recycled wood and paper } \\
\text { materials }\end{array}$} & $\begin{array}{l}\text { N/A or no } \\
\text { Significance }\end{array}$ & \begin{tabular}{|c|} 
Some \\
Significance
\end{tabular} & & $\begin{array}{l}\text { Moderate } \\
\text { Significance }\end{array}$ & & $\begin{array}{c}\text { High } \\
\text { Significance }\end{array}$ \\
\hline & & 0 & 1 & 2 & 3 & 4 & 5 \\
\hline \multirow{2}{*}{10} & Dir & & 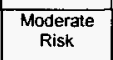 & & Low Risk & & $\begin{array}{c}\text { Very Low } \\
\text { Risk }\end{array}$ \\
\hline & & 0 & 1 & 2 & 3 & 4 & 5 \\
\hline \multirow{2}{*}{11} & \multirow{2}{*}{ Alternate uses for biomass } & $\begin{array}{l}\text { N/A or no } \\
\text { Significance }\end{array}$ & \begin{tabular}{|c|} 
Some \\
Significance
\end{tabular} & & \begin{tabular}{l|} 
Moderate \\
Significance
\end{tabular} & & $\begin{array}{l}\text { High } \\
\text { Significance }\end{array}$ \\
\hline & & 0 & 1 & 2 & 3 & 4 & 5 \\
\hline
\end{tabular}

Totals

\section{Comments}

\begin{tabular}{|c|c|c|}
\hline $\begin{array}{c}\text { CTO } \\
\text { Weighting }\end{array}$ & $\begin{array}{c}\text { Raw } \\
\text { Rating }\end{array}$ & $\begin{array}{c}\text { Weighted } \\
\text { Rating }\end{array}$ \\
\hline 10 & 5 & 50 \\
\hline $\begin{array}{c}\text { CTO } \\
\text { Weighting }\end{array}$ & $\begin{array}{l}\text { Raw } \\
\text { Rating }\end{array}$ & $\begin{array}{c}\text { Weighted } \\
\text { Rating }\end{array}$ \\
\hline 9 & 5 & 45 \\
\hline $\begin{array}{c}\text { CTO } \\
\text { Weighting }\end{array}$ & $\begin{array}{l}\text { Raw } \\
\text { Rating }\end{array}$ & 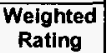 \\
\hline 8 & 3 & 24 \\
\hline $\begin{array}{c}\text { Cro } \\
\text { Weighting }\end{array}$ & $\begin{array}{l}\text { Raw } \\
\text { Rating }\end{array}$ & $\begin{array}{c}\text { Welghted } \\
\text { Rating }\end{array}$ \\
\hline 8 & 5 & 4 \\
\hline $\begin{array}{c}\text { CTO } \\
\text { Weighting }\end{array}$ & $\begin{array}{c}\text { Raw } \\
\text { Rating }\end{array}$ & $\begin{array}{c}\text { Weighted } \\
\text { Rating }\end{array}$ \\
\hline 7 & 4 & 28 \\
\hline $\begin{array}{c}\text { CTO } \\
\text { Weighting }\end{array}$ & $\begin{array}{l}\text { Raw } \\
\text { Rating }\end{array}$ & $\begin{array}{c}\text { Weighted } \\
\text { Rating }\end{array}$ \\
\hline 7 & 3 & 21 \\
\hline $\begin{array}{c}\text { CTO } \\
\text { Weighting }\end{array}$ & $\begin{array}{l}\text { Raw } \\
\text { Rating }\end{array}$ & $\begin{array}{c}\text { Weighted } \\
\text { Rating }\end{array}$ \\
\hline 7 & 0 & 0 \\
\hline $\begin{array}{c}\text { CTO } \\
\text { Weighting }\end{array}$ & $\begin{array}{c}\text { Raw } \\
\text { Rating }\end{array}$ & $\begin{array}{c}\text { Weighted } \\
\text { Rating }\end{array}$ \\
\hline 7 & 3 & \\
\hline $\begin{array}{c}\text { CTO } \\
\text { Weighting }\end{array}$ & $\begin{array}{c}\text { Raw } \\
\text { Rating }\end{array}$ & $\begin{array}{c}\text { Weighted } \\
\text { Rating }\end{array}$ \\
\hline 0 & 0 & \\
\hline $\begin{array}{c}\text { CTO } \\
\text { Weighting }\end{array}$ & $\begin{array}{c}\text { Raw } \\
\text { Rating }\end{array}$ & $\begin{array}{l}\text { Weighted } \\
\text { Rating }\end{array}$ \\
\hline 6 & 2 & 12 \\
\hline $\begin{array}{c}\text { CTO } \\
\text { Weighting }\end{array}$ & $\begin{array}{l}\text { Raw } \\
\text { Rating }\end{array}$ & \begin{tabular}{|c|}
$\begin{array}{c}\text { Weighted } \\
\text { Rating }\end{array}$ \\
\end{tabular} \\
\hline 5 & 0 & C \\
\hline
\end{tabular}

$4 \%$ increase in pulp yield contributes significantly to sustainability efforts by lowering required annual cut to sustain current pulp and paper production levels.

All Kraft mills are candidates for this technology. GPRA calculated energy savings on only those mills that require bleaching since the elimination of a bleaching is the point of the electrical energy savings. However, the pulping benefits are not limited to the bleached mills. Energy savings are estimated for bleached mills based on the elimination a bleach stage. Commercialization success will probably hinge on process benefits rather than energy benefits even though they will contribute to the overall economics.

$4 \%$ yield increase and a $20-40 \%$ pulp fiber increase with very little capital expenditure!

Capital effectiveness co-chair states this is a very popular project among his industry contacts. PI has had companies indicate strong interest in adopting this technology.

Beneficial effect of GL pre-treatment. How to economically get the benefit of directed green liquor pre-treatment.

Increase in sulfur make increase odor problems.

Although other work is underway in this area of research, much of it is proprietary. This effort will make the technology more widely available. IPSTs structure of industry advisory boards helps focus research efforts on critically important areas.

Not applicable.

Very low capital required - tank for pre-treatment of chip with green liquor chemicals. Corrosion is thought not to be a problem but has not been extensively investigated. Green liquor is known to increase the solubility of some iron compounds and adding the green liquor pretreatment could initiate some corrosion. Increased sulfur could be an odor risk issue. Not applicable. 
FOREST PRODUCTS INDUSTRY OF THE FUTURE - PORTFOLIO STUDY AND EVALUATION

24-1484 High-Capacity Gas-Fired Dryer

\begin{tabular}{|c|c|c|c|c|c|c|c|}
\hline 1 & $\begin{array}{l}\text { Sustained forest resource } \\
\text { management }\end{array}$ & \begin{tabular}{|c|} 
N/A o n no \\
Significance \\
0
\end{tabular} & \begin{tabular}{|c|} 
Some \\
Significance \\
1 \\
\end{tabular} & 2 & $\begin{array}{c}\text { Moderate } \\
\text { Significance } \\
3\end{array}$ & 4 & \begin{tabular}{|c} 
High \\
Significance \\
5
\end{tabular} \\
\hline 2 & $\begin{array}{l}\text { Size and extent of market } \\
\text { for the new technology }\end{array}$ & \begin{tabular}{|c} 
Very Small \\
0
\end{tabular} & $\begin{array}{c}\text { Small } \\
1\end{array}$ & 2 & $\begin{array}{c}\text { Medium } \\
3\end{array}$ & 4 & $\begin{array}{l}\text { Large } \\
5\end{array}$ \\
\hline 3 & Energy performance & \begin{tabular}{|c|} 
N/A or no \\
Significance \\
0
\end{tabular} & \begin{tabular}{|c|} 
Some \\
Stgnificance \\
1 \\
\end{tabular} & 2 & \begin{tabular}{|c|}
$\begin{array}{c}\text { Moderate } \\
\text { Significance } \\
3 \\
3\end{array}$ \\
\end{tabular} & 4 & $\begin{array}{c}\text { High } \\
\text { Significance } \\
5\end{array}$ \\
\hline 4 & Economic attractiveness & $\begin{array}{c}\text { Unatraccive } \\
0\end{array}$ & \begin{tabular}{|c|} 
Somewhat \\
Atractive \\
1 \\
\end{tabular} & 2 & $\begin{array}{c}\text { Atractive } \\
3\end{array}$ & 4 & $\begin{array}{c}\begin{array}{c}\text { Highly } \\
\text { Attractive }\end{array} \\
5\end{array}$ \\
\hline 5 & Technology champion & $\begin{array}{c}\text { None } \\
0\end{array}$ & \begin{tabular}{|c|} 
Assigned \\
Champion \\
1
\end{tabular} & 2 & \begin{tabular}{|c|} 
Independent \\
Champion \\
3
\end{tabular} & 4 & $\begin{array}{c}\text { Multiple } \\
\text { Champions } \\
5\end{array}$ \\
\hline 6 & $\begin{array}{l}\text { Scientific insights derived } \\
\text { from projed }\end{array}$ & $\begin{array}{c}\text { N/A or no } \\
\text { Significance } \\
0\end{array}$ & \begin{tabular}{|c|} 
Some \\
Significance \\
1 \\
\end{tabular} & 2 & \begin{tabular}{|c|} 
Moderate \\
Significance \\
3 \\
\end{tabular} & 4 & $\begin{array}{c}\text { High } \\
\text { Significance } \\
5\end{array}$ \\
\hline 7 & $\begin{array}{l}\text { Improved environmental } \\
\text { perfomance }\end{array}$ & $\begin{array}{c}\text { N/A o n n } \\
\text { Significance } \\
0\end{array}$ & \begin{tabular}{|c|} 
Some \\
Significance \\
1 \\
\end{tabular} & 2 & \begin{tabular}{|c|} 
Moderate \\
Significance \\
3 \\
\end{tabular} & 4 & $\begin{array}{c}\text { High } \\
\text { Significance } \\
5\end{array}$ \\
\hline 8 & Technological leadership & \begin{tabular}{|c|} 
N/A or no \\
Significance \\
0
\end{tabular} & \begin{tabular}{|c|} 
Some \\
Significance \\
1 \\
\end{tabular} & 2 & \begin{tabular}{|c|}
$\begin{array}{c}\text { Moderate } \\
\text { Significance } \\
3\end{array}$ \\
\end{tabular} & 4 & $\begin{array}{c}\text { High } \\
\text { Significance } \\
5\end{array}$ \\
\hline 9 & $\begin{array}{l}\text { Recycled wood and paper } \\
\text { meterials }\end{array}$ & $\begin{array}{c}\text { N/A or no } \\
\text { Significance } \\
0\end{array}$ & \begin{tabular}{|c|} 
Some \\
significance \\
1 \\
\end{tabular} & 2 & \begin{tabular}{|c|}
$\begin{array}{c}\text { Moderate } \\
\text { Signiifcance } \\
3\end{array}$ \\
\end{tabular} & 4 & $\begin{array}{c}\text { High } \\
\text { Significance } \\
5\end{array}$ \\
\hline 10 & Risk & $\begin{array}{c}\text { High Risk } \\
0\end{array}$ & $\begin{array}{c}\begin{array}{c}\text { Moderate } \\
\text { Risk }\end{array} \\
1\end{array}$ & 2 & $\begin{array}{c}\text { Low Risk } \\
3\end{array}$ & 4 & $\begin{array}{c}\begin{array}{c}\text { Very Low } \\
\text { Risk }\end{array} \\
5\end{array}$ \\
\hline 11 & 1 Alternate uses for biomass & $\begin{array}{c}\text { NA or no } \\
\text { Significance } \\
0\end{array}$ & \begin{tabular}{|c|} 
Some \\
Significance \\
1
\end{tabular} & 2 & \begin{tabular}{|c|} 
Moderate \\
Significance \\
3 \\
\end{tabular} & 4 & \begin{tabular}{|c} 
High \\
Significance \\
5
\end{tabular} \\
\hline
\end{tabular}

Totals

\begin{tabular}{|c|c|c|}
\hline $\begin{array}{c}\text { CTO } \\
\text { Weighting }\end{array}$ & $\begin{array}{l}\text { Raw } \\
\text { Rating }\end{array}$ & $\begin{array}{c}\text { Weighted } \\
\text { Rating }\end{array}$ \\
\hline 10 & 0 & 0 \\
\hline $\begin{array}{c}\text { CTO } \\
\text { Weighting }\end{array}$ & $\begin{array}{l}\text { Raw } \\
\text { Rating }\end{array}$ & $\begin{array}{c}\text { Weighted } \\
\text { Rating }\end{array}$ \\
\hline 9 & 3 & 27 \\
\hline $\begin{array}{c}\text { CTO } \\
\text { Weighting }\end{array}$ & $\begin{array}{l}\text { Raw } \\
\text { Rating }\end{array}$ & \begin{tabular}{|c|}
$\begin{array}{c}\text { Weighted } \\
\text { Rating }\end{array}$ \\
\end{tabular} \\
\hline 8 & 2 & 16 \\
\hline $\begin{array}{c}\text { CTO } \\
\text { Weighting }\end{array}$ & $\begin{array}{c}\text { Raw } \\
\text { Rating }\end{array}$ & $\begin{array}{c}\text { Weighted } \\
\text { Rating }\end{array}$ \\
\hline 8 & 3 & 24 \\
\hline $\begin{array}{c}\text { CTO } \\
\text { Weighting }\end{array}$ & $\begin{array}{c}\text { Raw } \\
\text { Rating }\end{array}$ & $\begin{array}{c}\text { Weighted } \\
\text { Rating }\end{array}$ \\
\hline 7 & 1 & 7 \\
\hline $\begin{array}{c}\text { CTO } \\
\text { Weighting }\end{array}$ & $\begin{array}{l}\text { Raw } \\
\text { Rating }\end{array}$ & $\begin{array}{c}\text { Weighted } \\
\text { Rating }\end{array}$ \\
\hline 7 & 4 & 2 \\
\hline $\begin{array}{c}\text { CTO } \\
\text { Weighting }\end{array}$ & $\begin{array}{l}\text { Raw } \\
\text { Rating }\end{array}$ & $\begin{array}{c}\text { Weighted } \\
\text { Rating }\end{array}$ \\
\hline 7 & 1 & 7 \\
\hline $\begin{array}{c}\text { CTO } \\
\text { Weighting }\end{array}$ & $\begin{array}{c}\text { Raw } \\
\text { Rating }\end{array}$ & $\begin{array}{c}\text { Weighted } \\
\text { Rating }\end{array}$ \\
\hline 7 & 4 & 2 \\
\hline $\begin{array}{c}\text { CTO } \\
\text { Weighting }\end{array}$ & $\begin{array}{l}\text { Raw } \\
\text { Rating }\end{array}$ & $\begin{array}{c}\text { Weighted } \\
\text { Rating }\end{array}$ \\
\hline 6 & 0 & 0 \\
\hline $\begin{array}{c}\text { CTO } \\
\text { Weighting }\end{array}$ & $\begin{array}{l}\text { Raw } \\
\text { Rating }\end{array}$ & $\begin{array}{c}\text { Weighted } \\
\text { Rating }\end{array}$ \\
\hline 6 & 3 & 18 \\
\hline \begin{tabular}{|c|} 
CTO \\
Weighting
\end{tabular} & $\begin{array}{l}\text { Raw } \\
\text { Rating }\end{array}$ & $\begin{array}{c}\text { Weighted } \\
\text { Rating }\end{array}$ \\
\hline 5 & 0 & 0 \\
\hline
\end{tabular}

$21 \quad 155$
Comments 
FOREST PRODUCTS INDUSTRY OF THE FUTURE - PORTFOLIO STUDY AND EVALUATION

25-1485 Continuous Displacement Dewatering

\begin{tabular}{|c|c|c|c|c|c|c|c|}
\hline 1 & $\begin{array}{l}\text { Sustained forest resource } \\
\text { management }\end{array}$ & $\begin{array}{c}\text { N/A or no } \\
\text { Significance } \\
0\end{array}$ & \begin{tabular}{|c|} 
Some \\
Significance \\
1 \\
1
\end{tabular} & 2 & $\begin{array}{c}\text { Moderate } \\
\text { Significance } \\
3\end{array}$ & 4 & $\begin{array}{c}\text { High } \\
\text { Significance } \\
5 \\
5\end{array}$ \\
\hline \multirow[b]{2}{*}{2} & & Very Small & Small & & Medium & & Large \\
\hline & $\begin{array}{l}\text { Size and extent of market } \\
\text { for the new tecthology }\end{array}$ & & & 2 & & 4 & \\
\hline \multirow{2}{*}{3} & & \begin{tabular}{|l} 
N/A or no \\
Significance
\end{tabular} & $\begin{array}{l}\text { Some } \\
\text { Significance }\end{array}$ & & \begin{tabular}{|l|}
$\begin{array}{l}\text { Moderate } \\
\text { Significance }\end{array}$ \\
\end{tabular} & & \begin{tabular}{|c} 
High \\
Significance
\end{tabular} \\
\hline & |Energy perromiance & 0 & 1 & 2 & 3 & 4 & 5 \\
\hline \multirow{2}{*}{4} & Fonomic atrontropes & & $\begin{array}{l}\text { Somewhat } \\
\text { Atractive }\end{array}$ & & Atrracive & & $\begin{array}{c}\text { Highly } \\
\text { Atractive }\end{array}$ \\
\hline & Jeconomic atractiveness & 0 & 1 & 2 & 3 & 4 & 5 \\
\hline \multirow{2}{*}{5} & Tochong champion & & \begin{tabular}{|c|} 
Assigned \\
Champion
\end{tabular} & & \begin{tabular}{|l} 
Independent \\
Champion
\end{tabular} & & \begin{tabular}{|c|} 
Multiple \\
Champions
\end{tabular} \\
\hline & 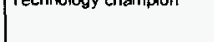 & 0 & 1 & 2 & 3 & 4 & 5 \\
\hline \multirow{2}{*}{6} & & \begin{tabular}{|l|} 
N/A or no \\
Significance
\end{tabular} & \begin{tabular}{|c|} 
Some \\
Significance
\end{tabular} & & \begin{tabular}{|l} 
Moderate \\
Significance
\end{tabular} & & \begin{tabular}{|c} 
High \\
Significance
\end{tabular} \\
\hline & from project & 0 & 1 & 2 & 3 & 4 & 5 \\
\hline \multirow{2}{*}{7} & & \begin{tabular}{|l} 
N/A or no \\
Significance
\end{tabular} & \begin{tabular}{|l} 
Some \\
Significance
\end{tabular} & & \begin{tabular}{|c|} 
Moderate \\
Significance
\end{tabular} & & $\begin{array}{c}\text { High } \\
\text { Significance }\end{array}$ \\
\hline & performance & 0 & 1 & 2 & 3 & 4 & 5 \\
\hline \multirow{2}{*}{8} & Tot & \begin{tabular}{|l} 
N/A or no \\
Significance
\end{tabular} & $\begin{array}{l}\text { Some } \\
\text { Significance }\end{array}$ & & \begin{tabular}{|c|c|} 
Moderate \\
Significance
\end{tabular} & & $\begin{array}{l}\text { High } \\
\text { Significance }\end{array}$ \\
\hline & |recrnological lezoerstip & 0 & 1 & 2 & 3 & 4 & 5 \\
\hline \multirow{2}{*}{9} & \multirow{2}{*}{$\begin{array}{l}\text { Recycled wood and paper } \\
\text { materials }\end{array}$} & \begin{tabular}{|l|} 
N/A or no \\
Significance
\end{tabular} & $\begin{array}{c}\text { Some } \\
\text { Significance }\end{array}$ & & \begin{tabular}{|c|} 
Moderate \\
Significance
\end{tabular} & & $\begin{array}{c}\text { High } \\
\text { Significance }\end{array}$ \\
\hline & & 0 & 1 & 2 & 3 & 4 & 5 \\
\hline \multirow{2}{*}{10} & & High Risk & $\begin{array}{l}\text { Moderate } \\
\text { Risk }\end{array}$ & & Low Risk & & 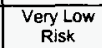 \\
\hline & |Risk & 0 & 1 & 2 & 3 & 4 & 5 \\
\hline \multirow{2}{*}{11} & 1 & \begin{tabular}{|c|} 
N/A or no \\
Significance
\end{tabular} & \begin{tabular}{|c|} 
Some \\
Significance
\end{tabular} & & \begin{tabular}{|c|} 
Moderate \\
Significance
\end{tabular} & & \begin{tabular}{|c|} 
High \\
Significance
\end{tabular} \\
\hline & Altemate uses for biomass & 0 & 1 & 2 & 3 & 4 & 5 \\
\hline
\end{tabular}

Totals

\section{Comments}

\begin{tabular}{|c|c|c|c|}
\hline \begin{tabular}{c|c|c|c|c|} 
CTO \\
Weighting \\
10
\end{tabular} & $\begin{array}{c}\text { Raw } \\
\text { Rating } \\
0\end{array}$ & $\begin{array}{c}\begin{array}{c}\text { Weighted } \\
\text { Rating } \\
0\end{array} \\
\end{array}$ & Not applicable. \\
\hline \begin{tabular}{c|c} 
CTO \\
Weighting \\
9
\end{tabular} & $\begin{array}{c}\text { Raw } \\
\text { Rating } \\
5\end{array}$ & \begin{tabular}{|c|}
$\begin{array}{c}\text { Weighted } \\
\text { Rating } \\
45\end{array}$ \\
\end{tabular} & $\begin{array}{l}\text { All paper machines are candidates for this technology. Since the largest energy use in the } \\
\text { industry is heat to dry water from the paper, this mechanical method will have large positive } \\
\text { economic benefits which will enhance it market penetration. }\end{array}$ \\
\hline \begin{tabular}{c|} 
CTO \\
Weighting \\
8
\end{tabular} & $\begin{array}{c}\text { Raw } \\
\text { Rating } \\
5\end{array}$ & $\begin{array}{c}\text { Weighted } \\
\text { Rating } \\
40\end{array}$ & $\begin{array}{l}\text { Process will increase solids at prior to the nip from approximately } 40 \% \text { to nearly } 60 \% \text { - in } \\
\text { effect removing by mechanical means one third of the water currently removed by the dryers. } \\
\text { GPRA preparer took issue with PIs BTU / ton assumptions but in any event, success with this } \\
\text { technology will have a highly significantly energy impact. }\end{array}$ \\
\hline \begin{tabular}{c|c|c|c|} 
CTO \\
Weighting \\
8
\end{tabular} & $\begin{array}{c}\text { Raw } \\
\text { Rating } \\
4\end{array}$ & \begin{tabular}{c|} 
Weighted \\
Rating \\
32
\end{tabular} & $\begin{array}{l}\text { Cost to build and install is unknown but PI believes this will be retrofitable to existing } \\
\text { machines. The combination of this technology with the promise of the dryer efficiency } \\
\text { research being conducted should allow relatively easy installation and providing higher speed } \\
\text { capabilities through the dryers. }\end{array}$ \\
\hline \begin{tabular}{c|c|c|c|} 
CTO \\
Weighting \\
7 \\
\end{tabular} & $\begin{array}{c}\text { Raw } \\
\text { Rating } \\
5\end{array}$ & 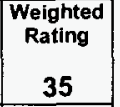 & High interest among the industry for this technology. \\
\hline $\begin{array}{c}\text { CTO } \\
\text { Weighting } \\
7\end{array}$ & $\begin{array}{c}\text { Raw } \\
\text { Rating } \\
3\end{array}$ & \begin{tabular}{|c|}
$\begin{array}{c}\text { Weighted } \\
\text { Rating } \\
21\end{array}$ \\
\end{tabular} & Voith is willing to disclose providing some means of intellectual property protection is in place. \\
\hline $\begin{array}{c}\text { CTO } \\
\text { Weighting } \\
7\end{array}$ & $\begin{array}{c}\text { Raw } \\
\text { Rating } \\
4\end{array}$ & \begin{tabular}{|c|} 
Weighted \\
Rating \\
28
\end{tabular} & $\begin{array}{l}1 / 3 \text { less heat energy (for drying) required per ton will bring indirect environmental benefits - } \\
\text { Lower } \mathrm{CO} 2 \text {, particulate on solid fuel. }\end{array}$ \\
\hline $\begin{array}{c}\text { CTO } \\
\text { Weighting } \\
7\end{array}$ & $\begin{array}{c}\text { Raw } \\
\text { Rating } \\
4\end{array}$ & \begin{tabular}{|c|} 
Weighted \\
Rating \\
28
\end{tabular} & $\begin{array}{l}\text { Mechanical means for removal of water is not new but this application and its potential } \\
\text { benefits to the industry are a significant step forward. }\end{array}$ \\
\hline $\begin{array}{c}\text { CTO } \\
\text { Weighting } \\
6\end{array}$ & $\begin{array}{c}\text { Raw } \\
\text { Rating } \\
0 \\
0\end{array}$ & $\begin{array}{c}\text { Weighted } \\
\text { Rating } \\
0\end{array}$ & Not applicable. \\
\hline $\begin{array}{c}\text { CTO } \\
\text { Weighting } \\
6 \\
\end{array}$ & $\begin{array}{c}\text { Raw } \\
\text { Rating } \\
2\end{array}$ & $\begin{array}{c}\begin{array}{c}\text { Weighted } \\
\text { Rating }\end{array} \\
12 \\
\end{array}$ & $\begin{array}{l}\text { Project risk is lower after early successes in lab paper machine and lower pressures achieved } \\
50 \% \text { solids. Risk in scale-up issue and commercialization to potential owners is disruption of } \\
\text { existing production facilities. }\end{array}$ \\
\hline $\begin{array}{c}\begin{array}{c}\text { CTO } \\
\text { Weighting }\end{array} \\
5\end{array}$ & $\begin{array}{c}\text { Raw } \\
\text { Rating } \\
0\end{array}$ & \begin{tabular}{|c|}
$\begin{array}{c}\text { Weighted } \\
\text { Rating } \\
0\end{array}$ \\
\end{tabular} & Not applicable. \\
\hline
\end{tabular}




\section{FOREST PRODUCTS INDUSTRY OF THE FUTURE - PORTFOLIO STUDY AND EVALUATION}

\section{6-1486 Borate Autocausticizing}

\begin{tabular}{|c|c|c|c|c|c|c|c|}
\hline 1 & $\begin{array}{l}\text { Sustained forest resource } \\
\text { management }\end{array}$ & $\begin{array}{c}\text { N/A or no } \\
\text { Significance } \\
0\end{array}$ & \begin{tabular}{|c|} 
Some \\
Significance \\
1 \\
\end{tabular} & 2 & \begin{tabular}{|c|} 
Moderate \\
Significance \\
3 \\
\end{tabular} & 4 & $\begin{array}{c}\text { High } \\
\text { Significance } \\
5\end{array}$ \\
\hline 2 & $\begin{array}{l}\text { Size and extent of market } \\
\text { for the new tecthrology }\end{array}$ & $\begin{array}{c}\text { Very Small } \\
0\end{array}$ & $\begin{array}{c}\text { Small } \\
1\end{array}$ & 2 & $\begin{array}{c}\text { Medium } \\
3\end{array}$ & 4 & $\begin{array}{c}\text { Large } \\
5\end{array}$ \\
\hline 3 & Energy performance & $\begin{array}{c}\text { N/A or ro } \\
\text { Significance } \\
0 \\
0\end{array}$ & \begin{tabular}{|c|} 
Some \\
Significance \\
1
\end{tabular} & 2 & \begin{tabular}{c|} 
Moderate \\
significance \\
3 \\
3
\end{tabular} & 4 & $\begin{array}{c}\text { High } \\
\text { Significance } \\
5\end{array}$ \\
\hline 4 & Economic atractiveness & $\begin{array}{c}\text { Unattractive } \\
0\end{array}$ & \begin{tabular}{|c|}
$\begin{array}{c}\text { Somewhat } \\
\text { Atradive } \\
1\end{array}$ \\
\end{tabular} & 2 & $\begin{array}{c}\text { Altractive } \\
3\end{array}$ & 4 & 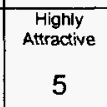 \\
\hline 5 & Technology champion & $\begin{array}{c}\text { None } \\
0\end{array}$ & \begin{tabular}{|c|} 
Assigned \\
Champian \\
1 \\
\end{tabular} & 2 & \begin{tabular}{|c|} 
Independent \\
champion \\
3 \\
\end{tabular} & 4 & $\begin{array}{c}\text { Multiple } \\
\text { Champions } \\
5\end{array}$ \\
\hline 6 & $\begin{array}{l}\text { Scientific insignts derived } \\
\text { from project }\end{array}$ & $\begin{array}{c}\text { N/A or no } \\
\text { Significance } \\
0\end{array}$ & \begin{tabular}{|c|} 
Some \\
Significance \\
1
\end{tabular} & 2 & \begin{tabular}{|c|} 
Moderate \\
Significance \\
3 \\
\end{tabular} & 4 & $\begin{array}{c}\text { High } \\
\text { Significance } \\
5\end{array}$ \\
\hline 7 & $\begin{array}{l}\text { Improved environmental } \\
\text { periomance }\end{array}$ & $\begin{array}{c}\text { N/A or no } \\
\text { Significance } \\
0\end{array}$ & \begin{tabular}{|c|} 
Some \\
significance \\
1
\end{tabular} & 2 & \begin{tabular}{|c|} 
Moderate \\
Significance \\
3 \\
\end{tabular} & 4 & $\begin{array}{c}\text { High } \\
\text { Significance } \\
5 \\
5\end{array}$ \\
\hline 8 & Technological leadership & $\begin{array}{c}\text { N/A or no } \\
\text { Significance } \\
0\end{array}$ & \begin{tabular}{|c|} 
Some \\
significance \\
1
\end{tabular} & 2 & \begin{tabular}{|c|} 
Moderate \\
Significance \\
3 \\
\end{tabular} & 4 & \begin{tabular}{|c} 
High \\
Significance \\
5 \\
5
\end{tabular} \\
\hline 9 & $\begin{array}{l}\text { Recycled wood and paper } \\
\text { materials }\end{array}$ & $\begin{array}{c}\text { N/A or no } \\
\text { Significance } \\
0 \\
0\end{array}$ & $\begin{array}{c}\text { Some } \\
\text { significance } \\
1\end{array}$ & 2 & \begin{tabular}{|c|} 
Moderate \\
Significance \\
3 \\
\end{tabular} & 4 & $\begin{array}{c}\text { Migh } \\
\text { Significance } \\
5\end{array}$ \\
\hline 10 & Risk & $\begin{array}{c}\text { High Risk } \\
0\end{array}$ & $\begin{array}{c}\begin{array}{c}\text { Moderate } \\
\text { Risk } \\
1\end{array} \\
1\end{array}$ & 2 & $\begin{array}{c}\text { Low Risk } \\
3\end{array}$ & 4 & $\begin{array}{c}\begin{array}{c}\text { Very Low } \\
\text { Risk } \\
5\end{array} \\
5\end{array}$ \\
\hline 11 & Alternate uses for biomass & $\begin{array}{c}\text { N/A or mo } \\
\text { Significance } \\
0\end{array}$ & $\begin{array}{c}\text { Some } \\
\text { Significance } \\
1\end{array}$ & 2 & \begin{tabular}{|c|} 
Moderate \\
Significance \\
3 \\
\end{tabular} & 4 & $\begin{array}{c}\text { High } \\
\text { Significance } \\
5 \\
5\end{array}$ \\
\hline
\end{tabular}

Totals

\section{Comments}

\begin{tabular}{|c|c|c|c|}
\hline $\begin{array}{c}\text { CTO } \\
\text { Weighting } \\
10\end{array}$ & $\begin{array}{c}\text { Raw } \\
\text { Rating } \\
1\end{array}$ & $\begin{array}{c}\text { Weighted } \\
\text { Rating } \\
10\end{array}$ & $\begin{array}{l}1-1.5 \% \text { pulp yield increase has been seen in the trials. Efforts are underway to confirm this } \\
\text { yield increase can be repeated. Confidence is not yet high that other trial will see the yield } \\
\text { increase. }\end{array}$ \\
\hline $\begin{array}{c}\text { CTO } \\
\text { Weighting }\end{array}$ & $\begin{array}{l}\text { Raw } \\
\text { Rating }\end{array}$ & $\begin{array}{c}\text { Weighted } \\
\text { Rating }\end{array}$ & $\begin{array}{l}\text { Given success with research and mill trials, process could become the standard causticizing } \\
\text { method. No technical reason why } 100 \% \text { borate autocausticizing could not be used. }\end{array}$ \\
\hline 9 & 4 & 36 & \\
\hline $\begin{array}{c}\text { CTO } \\
\text { Weighting }\end{array}$ & $\begin{array}{l}\text { Raw } \\
\text { Rating }\end{array}$ & $\begin{array}{c}\text { Weighted } \\
\text { Rating }\end{array}$ & $\begin{array}{l}\text { Elimination of the lime kiln with attendant reduction of its energy requirements is the major } \\
\text { energy benefit of the technology. }\end{array}$ \\
\hline 8 & 3 & 24 & \\
\hline $\begin{array}{c}\text { CTO } \\
\text { Weighting }\end{array}$ & $\begin{array}{c}\text { Raw } \\
\text { Rating }\end{array}$ & $\begin{array}{c}\text { Weighted } \\
\text { Rating }\end{array}$ & Will allow capacity expansion of the furnace and digester with essentially no capital. \\
\hline 8 & 5 & 40 & \\
\hline $\begin{array}{c}\text { CTO } \\
\text { Weighting }\end{array}$ & $\begin{array}{l}\text { Raw } \\
\text { Rating }\end{array}$ & $\begin{array}{c}\begin{array}{c}\text { Weighted } \\
\text { Rating }\end{array} \\
\end{array}$ & $\begin{array}{l}\text { Charles Bair industrial partner representative. Mill personnel at mills where trials have been } \\
\text { heid. }\end{array}$ \\
\hline 7 & 4 & 28 & \\
\hline $\begin{array}{l}\text { CTO } \\
\text { Weighting } \\
7\end{array}$ & $\begin{array}{c}\text { Raw } \\
\text { Rating } \\
4\end{array}$ & \begin{tabular}{|c|}
$\begin{array}{c}\text { Weighted } \\
\text { Rating } \\
28\end{array}$ \\
\end{tabular} & $\begin{array}{l}\text { Furnace decarbonizing reactions occur as predicted. Causticizing efficiency appears to } \\
\text { increase. Borate may increase the efficiency of the pulping reaction. Less energy required for } \\
\text { calcining. }\end{array}$ \\
\hline $\begin{array}{c}\text { CTO } \\
\text { Weighting }\end{array}$ & $\begin{array}{c}\text { Raw } \\
\text { Rating }\end{array}$ & $\begin{array}{c}\text { Weighted } \\
\text { Rating }\end{array}$ & $\mathrm{CO} 2$ reduction from reduced fuel at the lime kiln. \\
\hline 7 & 2 & 14 & \\
\hline $\begin{array}{c}\text { CTO } \\
\text { Weighting } \\
7\end{array}$ & $\begin{array}{c}\text { Raw } \\
\text { Rating } \\
4\end{array}$ & \begin{tabular}{|c|}
$\begin{array}{c}\text { Weighted } \\
\text { Rating } \\
28\end{array}$ \\
2
\end{tabular} & $\begin{array}{l}\text { Project will take concept and demonstrate that } 100 \% \text { autocausticizing, while possible is not } \\
\text { required. Understanding and demonstrating the proposed stoichiometry of borate } \\
\text { autocausticizing. }\end{array}$ \\
\hline $\begin{array}{c}\text { CTO } \\
\text { Weighting }\end{array}$ & $\begin{array}{l}\text { Raw } \\
\text { Rating }\end{array}$ & \begin{tabular}{|c|} 
Weighted \\
Rating
\end{tabular} & Not applicable. \\
\hline 6 & 0 & $\mathbf{0}$ & \\
\hline $\begin{array}{c}\text { CTO } \\
\text { Weighting } \\
6\end{array}$ & $\begin{array}{c}\text { Raw } \\
\text { Rating } \\
5\end{array}$ & $\begin{array}{c}\text { Weighted } \\
\text { Rating } \\
30\end{array}$ & $\begin{array}{l}\text { Risk to research success is very low. Risk to commercialization also very low. Essentially no } \\
\text { capital required. A mill can revert to its existing systems if any problems arise. Transition to } \\
\text { use of borates can be gradual. }\end{array}$ \\
\hline $\begin{array}{c}\text { CTO } \\
\text { Weighting }\end{array}$ & $\begin{array}{l}\text { Raw } \\
\text { Rating }\end{array}$ & $\begin{array}{c}\text { Weighted } \\
\text { Rating }\end{array}$ & Not applicable. \\
\hline 5 & 0 & $\mathbf{0}$ & \\
\hline
\end{tabular}




\section{7-1487 Fast Curing of Wood Composites}

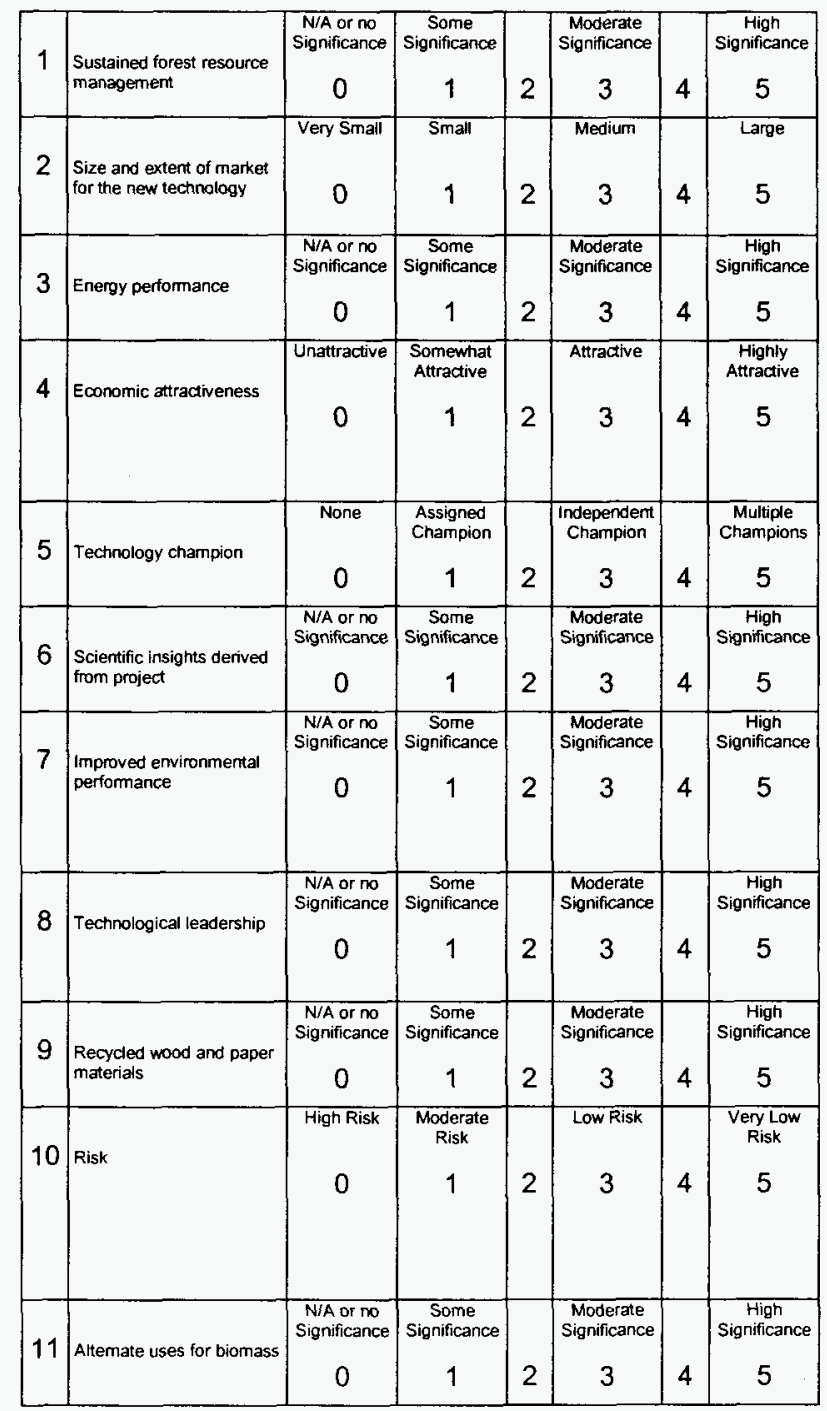

Totals

\begin{tabular}{|c|c|c|}
\hline $\begin{array}{c}\text { Cro } \\
\text { Weighting }\end{array}$ & $\begin{array}{l}\text { Raw } \\
\text { Rating }\end{array}$ & $\begin{array}{c}\text { Weighted } \\
\text { Rating }\end{array}$ \\
\hline 10 & 0 & 0 \\
\hline $\begin{array}{c}\text { CTOO } \\
\text { Weighting }\end{array}$ & $\begin{array}{l}\text { Raw } \\
\text { Rating }\end{array}$ & $\begin{array}{c}\text { Weighted } \\
\text { Rating }\end{array}$ \\
\hline 9 & 5 & 45 \\
\hline $\begin{array}{c}\text { CTO } \\
\text { Weighting }\end{array}$ & $\begin{array}{l}\text { Raw } \\
\text { Rating }\end{array}$ & $\begin{array}{c}\begin{array}{c}\text { Weighted } \\
\text { Rating }\end{array} \\
\text { (a) }\end{array}$ \\
\hline 8 & 4 & 32 \\
\hline $\begin{array}{l}\text { CTO } \\
\text { Weighting }\end{array}$ & $\begin{array}{l}\text { Raw } \\
\text { Rating }\end{array}$ & $\begin{array}{c}\text { Weighted } \\
\text { Rating }\end{array}$ \\
\hline 8 & 5 & 40 \\
\hline $\begin{array}{c}\text { CTO } \\
\text { Weighting }\end{array}$ & $\begin{array}{c}\begin{array}{c}\text { Raw } \\
\text { Rating }\end{array} \\
\end{array}$ & $\begin{array}{c}\text { Weighted } \\
\text { Rating }\end{array}$ \\
\hline 7 & 5 & 35 \\
\hline $\begin{array}{c}\text { CTO } \\
\text { Weighting }\end{array}$ & $\begin{array}{l}\text { Raw } \\
\text { Rating }\end{array}$ & $\begin{array}{c}\text { Weighted } \\
\text { Rating }\end{array}$ \\
\hline 7 & 4 & 28 \\
\hline $\begin{array}{c}\text { CTO } \\
\text { Weighting }\end{array}$ & $\begin{array}{l}\text { Raw } \\
\text { Rating }\end{array}$ & $\begin{array}{c}\text { Weighted } \\
\text { Rating }\end{array}$ \\
\hline 7 & 3 & 21 \\
\hline $\begin{array}{c}\text { CTO } \\
\text { Weighting }\end{array}$ & $\begin{array}{c}\text { Raw } \\
\text { Rating }\end{array}$ & $\begin{array}{c}\text { Weighted } \\
\text { Rating }\end{array}$ \\
\hline 7 & 3 & 21 \\
\hline $\begin{array}{c}\text { cTo } \\
\text { Weighting }\end{array}$ & $\begin{array}{l}\text { Raw } \\
\text { Rating }\end{array}$ & $\begin{array}{l}\text { Weighted } \\
\text { Rating }\end{array}$ \\
\hline 6 & 0 & 0 \\
\hline $\begin{array}{l}\text { CTo } \\
\text { Weighting }\end{array}$ & $\begin{array}{c}\text { Raw } \\
\text { Rating }\end{array}$ & $\begin{array}{c}\text { Weighted } \\
\text { Rating }\end{array}$ \\
\hline 6 & 4 & 24 \\
\hline $\begin{array}{c}\text { CTO } \\
\text { Ceighting }\end{array}$ & $\begin{array}{c}\text { Raw } \\
\text { Rating }\end{array}$ & $\begin{array}{c}\text { Weighted } \\
\text { Rating }\end{array}$ \\
\hline 5 & 0 & 0 \\
\hline & 33 & 246 \\
\hline
\end{tabular}

E-28
Comments

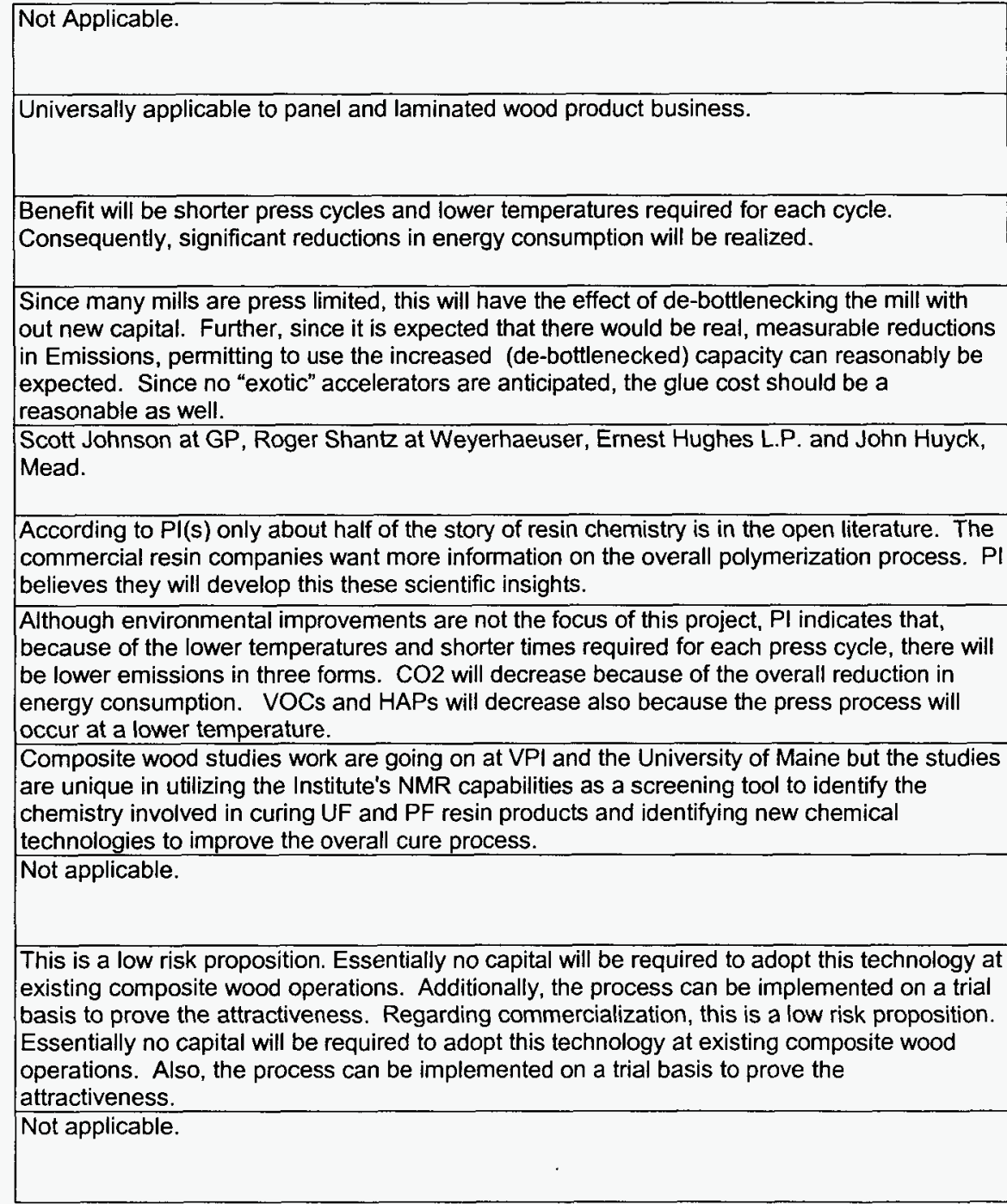

Final Report 


\section{FOREST PRODUCTS INDUSTRY OF THE FUTURE - PORTFOLIO STUDY AND EVALUATION}

\section{8-772 Acoustic Separation Technology}

\begin{tabular}{|c|c|c|c|c|c|c|c|}
\hline 1 & $\begin{array}{l}\text { Sustained forest resource } \\
\text { management }\end{array}$ & $\begin{array}{c}\text { N/A or no } \\
\text { Significance } \\
0\end{array}$ & $\begin{array}{c}\text { Some } \\
\text { Significance } \\
1\end{array}$ & 2 & \begin{tabular}{|} 
Moderate \\
Significance \\
3 \\
3
\end{tabular} & 4 & \begin{tabular}{|c|}
$\begin{array}{c}\text { High } \\
\text { Significance } \\
5 \\
5\end{array}$ \\
\end{tabular} \\
\hline 2 & $\begin{array}{l}\text { Size and extent of market } \\
\text { for the new techrology }\end{array}$ & $\begin{array}{c}\text { Very Small } \\
0\end{array}$ & $\begin{array}{c}\text { Small } \\
1\end{array}$ & 2 & $\begin{array}{c}\text { Medium } \\
3\end{array}$ & 4 & $\begin{array}{l}\text { Lange } \\
5\end{array}$ \\
\hline 3 & Energy performance & $\begin{array}{c}\text { N/A o n no } \\
\text { Significance } \\
0\end{array}$ & \begin{tabular}{|c|} 
Some \\
Significance \\
1
\end{tabular} & 2 & \begin{tabular}{|c|} 
Moderate \\
Significance \\
3 \\
3
\end{tabular} & 4 & $\begin{array}{c}\text { High } \\
\text { Significance } \\
5 \\
5\end{array}$ \\
\hline 4 & Economic attractiveness & $\begin{array}{c}\text { Unattractive } \\
0\end{array}$ & \begin{tabular}{|c|}
$\begin{array}{c}\text { Somewhat } \\
\text { Attractive } \\
1\end{array}$ \\
\end{tabular} & 2 & $\begin{array}{c}\text { Attractive } \\
3 \\
3\end{array}$ & 4 & $\begin{array}{c}\begin{array}{c}\text { Highty } \\
\text { Attractive }\end{array} \\
5\end{array}$ \\
\hline 5 & Technology champion & $\begin{array}{c}\text { None } \\
0\end{array}$ & $\begin{array}{c}\text { Assigned } \\
\text { Champion } \\
1\end{array}$ & 2 & $\begin{array}{c}\begin{array}{c}\text { Independent } \\
\text { Champion } \\
3\end{array} \\
\end{array}$ & 4 & \begin{tabular}{|c} 
Multiple \\
Champions \\
5 \\
5
\end{tabular} \\
\hline 6 & $\begin{array}{l}\text { Scientific insights derived } \\
\text { from project }\end{array}$ & \begin{tabular}{|c} 
N/A or no \\
Significance \\
0
\end{tabular} & \begin{tabular}{|c|} 
Some \\
Significance \\
1
\end{tabular} & 2 & $\begin{array}{c}\text { Moderate } \\
\text { Significance } \\
3 \\
3\end{array}$ & 4 & \begin{tabular}{|c} 
High \\
Significance \\
5 \\
5
\end{tabular} \\
\hline 7 & $\begin{array}{l}\text { Improved environmental } \\
\text { performance }\end{array}$ & \begin{tabular}{|c} 
NAA or no \\
Significance \\
0
\end{tabular} & \begin{tabular}{|c|} 
Some \\
Significance \\
1
\end{tabular} & 2 & \begin{tabular}{|c|} 
Moderate \\
Significance \\
3 \\
3
\end{tabular} & 4 & \begin{tabular}{|c} 
High \\
Significance \\
5
\end{tabular} \\
\hline 8 & Technological leadership & $\begin{array}{c}\text { N/A or no } \\
\text { Significance } \\
0\end{array}$ & \begin{tabular}{|c|} 
Some \\
Significance \\
1 \\
\end{tabular} & 2 & \begin{tabular}{|c|} 
Moderate \\
Significance \\
3 \\
3
\end{tabular} & 4 & $\begin{array}{c}\text { High } \\
\text { Significance } \\
5\end{array}$ \\
\hline 9 & $\begin{array}{l}\text { Recycled wood and paper } \\
\text { materials }\end{array}$ & \begin{tabular}{|c} 
N/A or no \\
Significance \\
0
\end{tabular} & \begin{tabular}{|c|} 
Some \\
Significance \\
1 \\
\end{tabular} & 2 & \begin{tabular}{|c|} 
Moderate \\
Significance \\
3 \\
3
\end{tabular} & 4 & $\begin{array}{c}\text { High } \\
\text { Significance } \\
5\end{array}$ \\
\hline 10 & Risk & $\begin{array}{c}\text { High Risk } \\
0 \\
0\end{array}$ & \begin{tabular}{|c}
$\begin{array}{c}\text { Moderate } \\
\text { Risk }\end{array}$ \\
1
\end{tabular} & 2 & $\begin{array}{c}\text { Low Risk } \\
3\end{array}$ & 4 & $\begin{array}{c}\text { Very Low } \\
\text { Risk } \\
5\end{array}$ \\
\hline 11 & Alternate uses for biomass & \begin{tabular}{|c} 
N/A or no \\
Significance \\
0
\end{tabular} & \begin{tabular}{|c|} 
Some \\
Significance \\
1
\end{tabular} & 2 & \begin{tabular}{|c|} 
Moderate \\
Significance \\
3 \\
3
\end{tabular} & 4 & $\begin{array}{c}\text { High } \\
\text { Significance } \\
5 \\
5\end{array}$ \\
\hline
\end{tabular}

Totals

\section{Comments}

\begin{tabular}{|c|c|c|}
\hline $\begin{array}{c}\text { CTO } \\
\text { Weighting } \\
10\end{array}$ & $\begin{array}{c}\text { Raw } \\
\text { Rating } \\
0\end{array}$ & \begin{tabular}{|c|} 
Weighted \\
Rating \\
0
\end{tabular} \\
\hline $\begin{array}{c}\text { CTO } \\
\text { Weighting }\end{array}$ & $\begin{array}{l}\text { Raw } \\
\text { Rating }\end{array}$ & \begin{tabular}{|c|} 
Weighted \\
Rating
\end{tabular} \\
\hline 9 & 5 & 45 \\
\hline $\begin{array}{c}\text { CTO } \\
\text { Weighting }\end{array}$ & $\begin{array}{c}\text { Raw } \\
\text { Rating }\end{array}$ & \begin{tabular}{|c|} 
Weighted \\
Rating
\end{tabular} \\
\hline 8 & 2 & 16 \\
\hline $\begin{array}{c}\text { CTO } \\
\text { Weighting }\end{array}$ & $\begin{array}{c}\text { Raw } \\
\text { Rating }\end{array}$ & $\begin{array}{c}\text { Weighted } \\
\text { Rating }\end{array}$ \\
\hline 8 & 4 & 32 \\
\hline $\begin{array}{c}\text { CTO } \\
\text { Weighting }\end{array}$ & $\begin{array}{l}\text { Raw } \\
\text { Rating }\end{array}$ & $\begin{array}{c}\text { Weighted } \\
\text { Rating }\end{array}$ \\
\hline 7 & 0 & 0 \\
\hline $\begin{array}{c}\text { CTO } \\
\text { Weighting }\end{array}$ & $\begin{array}{c}\text { Raw } \\
\text { Rating }\end{array}$ & $\begin{array}{c}\text { Weighted } \\
\text { Rating }\end{array}$ \\
\hline 7 & 3 & 21 \\
\hline $\begin{array}{c}\text { CTO } \\
\text { Weighting }\end{array}$ & $\begin{array}{c}\text { Raw } \\
\text { Rating }\end{array}$ & $\begin{array}{c}\text { Weighted } \\
\text { Rating }\end{array}$ \\
\hline 7 & 4 & 28 \\
\hline $\begin{array}{c}\text { CTO } \\
\text { Weighting }\end{array}$ & $\begin{array}{c}\text { Raw } \\
\text { Rating }\end{array}$ & $\begin{array}{c}\text { Weighted } \\
\text { Rating }\end{array}$ \\
\hline 7 & 3 & 21 \\
\hline $\begin{array}{c}\text { CTO } \\
\text { Weighting }\end{array}$ & $\begin{array}{l}\text { Raw } \\
\text { Rating }\end{array}$ & $\begin{array}{c}\begin{array}{c}\text { Weighted } \\
\text { Rating }\end{array} \\
\end{array}$ \\
\hline 6 & 1 & 6 \\
\hline $\begin{array}{c}\text { CTO } \\
\text { Weighting }\end{array}$ & $\begin{array}{c}\text { Raw } \\
\text { Rating }\end{array}$ & \begin{tabular}{|c|} 
Weighted \\
Rating
\end{tabular} \\
\hline 6 & 1 & 6 \\
\hline $\begin{array}{c}\text { Cro } \\
\text { Weighting }\end{array}$ & $\begin{array}{l}\text { Raw } \\
\text { Rating }\end{array}$ & $\begin{array}{c}\text { Weighted } \\
\text { Rating }\end{array}$ \\
\hline 5 & 0 & 0 \\
\hline
\end{tabular}

\begin{tabular}{|c|}
\hline Not applicable for sustainable forestry. \\
\hline $\begin{array}{l}\text { Market potential is good, but the fundamental nature of the technology takes a long time to } \\
\text { penetrate the market and the developmental problems with the transducers may slow market } \\
\text { penetration. }\end{array}$ \\
\hline $\begin{array}{l}\text { Offers potential improvement in energy consumption, but to some degree this improvement is } \\
\text { tied to design refinements and savings that result as the technology matures over several } \\
\text { years. }\end{array}$ \\
\hline Good economic attractiveness because of its simplicity. \\
\hline State of Georgia has agreed to fund for another year, but no real industry champion. \\
\hline $\begin{array}{l}\text { The science has wide application even in other industries, however the failure to identify a } \\
\text { reliable transducer for this application is critical to other applications as well as to this one. }\end{array}$ \\
\hline $\begin{array}{l}\text { Offers good, solid environmental improvements because this technology replaces an open } \\
\text { system with a closed system. }\end{array}$ \\
\hline $\begin{array}{l}\text { Good technology that needs to be proven in a pilot operation, but the failure to develop a } \\
\text { functional transducer makes this project vulnerable to ultimate failure, i.e. they may probably } \\
\text { run out of funding before they solve the transducer problems. }\end{array}$ \\
\hline This project would enhance the use of recycled fiber, but is not essential technology. \\
\hline $\begin{array}{l}\text { The poor performance and reliability of the transducers during pilot runs and testing seem to } \\
\text { indicate that there are a number of risks with this technology. However, if the next round of } \\
\text { testing were to successfully develop a functional dependable transducer, then the risks of this } \\
\text { project would be substantially altered. }\end{array}$ \\
\hline Not applicable. \\
\hline
\end{tabular}


29-944 Easily Removable Cationic PSAs

\begin{tabular}{|c|c|c|c|c|c|c|c|}
\hline \multirow{2}{*}{1} & \multirow{2}{*}{$\begin{array}{l}\text { Sustained forest resource } \\
\text { management }\end{array}$} & \begin{tabular}{|l|} 
N/A or no \\
Significance
\end{tabular} & \begin{tabular}{c|} 
Some \\
Significance
\end{tabular} & & $\begin{array}{l}\text { Moderate } \\
\text { Significance }\end{array}$ & & $\begin{array}{c}\text { High } \\
\text { Significance }\end{array}$ \\
\hline & & 0 & 1 & 2 & 3 & 4 & 5 \\
\hline \multirow[b]{2}{*}{2} & & \begin{tabular}{|l|} 
Very Small \\
\end{tabular} & Small & & Medium & & Large \\
\hline & $\begin{array}{l}\text { Size and extent of market } \\
\text { for the new technology }\end{array}$ & 0 & 1 & $?$ & 3 & 1 & 5 \\
\hline \multirow{3}{*}{3} & & N/A or no & Some & & Moderate & & High \\
\hline & Energy performance & & - & 21 & 20 & 4 & 5 \\
\hline & & 0 & 1 & 21 & 3 & 4 & 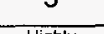 \\
\hline \multirow{2}{*}{4} & & Unattractive & $\begin{array}{l}\text { Somemtiat } \\
\text { Atradive }\end{array}$ & & Attractive & & $\begin{array}{c}\text { Highly } \\
\text { Attractive }\end{array}$ \\
\hline & | Economic attraativeness & 0 & 1 & 2 & 3 & 4 & 5 \\
\hline \multirow{2}{*}{5} & T Tochoony champing & & $\begin{array}{l}\text { Assigned } \\
\text { Champion }\end{array}$ & & $\begin{array}{c}\text { Independemt } \\
\text { Champion }\end{array}$ & & $\begin{array}{l}\text { Multiple } \\
\text { champions }\end{array}$ \\
\hline & Tecrinoilogy crampion & 0 & 1 & 2 & 3 & 4 & 5 \\
\hline \multirow{2}{*}{6} & & \begin{tabular}{|l|} 
N/A or no \\
Significance
\end{tabular} & $\begin{array}{l}\text { Some } \\
\text { Significance } \\
\end{array}$ & & $\begin{array}{l}\text { Moderate } \\
\text { Significance }\end{array}$ & & $\begin{array}{l}\text { Pligh } \\
\text { Significance }\end{array}$ \\
\hline & from pro & 0 & 1 & 2 & 3 & 4 & 5 \\
\hline \multirow{2}{*}{7} & & $\begin{array}{l}\text { N/A or no } \\
\text { Significance }\end{array}$ & \begin{tabular}{|c|} 
Some \\
Significance
\end{tabular} & & $\begin{array}{l}\text { Moderate } \\
\text { Significance }\end{array}$ & & $\begin{array}{c}\text { Migh } \\
\text { Significance }\end{array}$ \\
\hline & perform & 0 & 1 & 2 & 3 & 4 & 5 \\
\hline \multirow{2}{*}{8} & Tont & $\begin{array}{l}\text { N/A or no } \\
\text { Significance }\end{array}$ & \begin{tabular}{|c|} 
Some \\
Significance
\end{tabular} & & $\begin{array}{l}\text { Moderate } \\
\text { Significance }\end{array}$ & & $\begin{array}{c}\text { High } \\
\text { Significance }\end{array}$ \\
\hline & & 0 & 1 & 2 & 3 & 4 & 5 \\
\hline \multirow{2}{*}{9} & & $\begin{array}{l}\text { N/A or no } \\
\text { Significance }\end{array}$ & \begin{tabular}{|c|} 
Some \\
Significance
\end{tabular} & & \begin{tabular}{|l} 
Moderate \\
Significance
\end{tabular} & & $\begin{array}{c}\text { High } \\
\text { Significance }\end{array}$ \\
\hline & mater & 0 & 1 & 2 & 3 & 4 & 5 \\
\hline \multirow{2}{*}{10} & Dir & & \begin{tabular}{|c|} 
Moderate \\
Risk
\end{tabular} & & \begin{tabular}{|l|} 
Low Risk \\
\end{tabular} & & $\begin{array}{l}\text { Very Low } \\
\text { Risk }\end{array}$ \\
\hline & RISK & 0 & 1 & 2 & 3 & 4 & 5 \\
\hline \multirow{2}{*}{11} & \multirow{2}{*}{ Alternate uses for biomass } & \begin{tabular}{|l|} 
N/A or no \\
Significance \\
\end{tabular} & \begin{tabular}{|c|} 
Some \\
Significance
\end{tabular} & & $\begin{array}{l}\text { Moderate } \\
\text { Significance }\end{array}$ & & $\begin{array}{l}\text { High } \\
\text { Significance }\end{array}$ \\
\hline & & 0 & 1 & 2 & 3 & 4 & 5 \\
\hline
\end{tabular}

Totals

\begin{tabular}{|c|c|c|}
\hline $\begin{array}{c}\text { CTO } \\
\text { Weighting } \\
10 \\
\end{array}$ & $\begin{array}{c}\text { Raw } \\
\text { Rating } \\
1 \\
\end{array}$ & 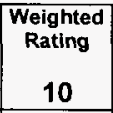 \\
\hline $\begin{array}{c}\text { CTO } \\
\text { Weighting }\end{array}$ & $\begin{array}{l}\text { Raw } \\
\text { Rating }\end{array}$ & $\begin{array}{c}\text { Weighted } \\
\text { Rating }\end{array}$ \\
\hline 9 & 4 & 36 \\
\hline $\begin{array}{c}\text { CTO } \\
\text { Weighting }\end{array}$ & $\begin{array}{l}\text { Raw } \\
\text { Rating }\end{array}$ & Rating \\
\hline 8 & 3 & 24 \\
\hline $\begin{array}{c}\text { CTO } \\
\text { Weighting }\end{array}$ & $\begin{array}{c}\text { Raw } \\
\text { Rating }\end{array}$ & $\begin{array}{c}\text { Weighted } \\
\text { Rating }\end{array}$ \\
\hline 8 & 4 & 3 \\
\hline $\begin{array}{c}\text { CTO } \\
\text { Weighting }\end{array}$ & $\begin{array}{c}\text { Raw } \\
\text { Rating }\end{array}$ & $\begin{array}{c}\text { Weighted } \\
\text { Rating }\end{array}$ \\
\hline 7 & 3 & 21 \\
\hline $\begin{array}{c}\text { CTO } \\
\text { Weighting }\end{array}$ & $\begin{array}{c}\text { Raw } \\
\text { Rating }\end{array}$ & $\begin{array}{c}\text { Weighted } \\
\text { Rating }\end{array}$ \\
\hline 7 & 3 & \\
\hline $\begin{array}{c}\text { CTO } \\
\text { Weighting }\end{array}$ & $\begin{array}{c}\text { Raw } \\
\text { Rating }\end{array}$ & $\begin{array}{c}\text { Weighted } \\
\text { Rating }\end{array}$ \\
\hline 8 & 7 & \\
\hline \begin{tabular}{|c|c|} 
CTO \\
Weighting
\end{tabular} & $\begin{array}{c}\text { Raw } \\
\text { Rating }\end{array}$ & $\begin{array}{c}\text { Weighted } \\
\text { Rating }\end{array}$ \\
\hline 7 & 4 & 28 \\
\hline $\begin{array}{c}\text { CTO } \\
\text { Weighting }\end{array}$ & $\begin{array}{c}\text { Raw } \\
\text { Rating }\end{array}$ & \begin{tabular}{|c} 
Weighted \\
Rating
\end{tabular} \\
\hline b & J & \\
\hline \begin{tabular}{|c|} 
CTO \\
Weighting
\end{tabular} & $\begin{array}{c}\text { Raw } \\
\text { Rating }\end{array}$ & $\begin{array}{c}\text { Weighted } \\
\text { Rating }\end{array}$ \\
\hline 6 & 4 & \\
\hline $\begin{array}{c}\text { CTO } \\
\text { Weighting }\end{array}$ & $\begin{array}{c}\text { Raw } \\
\text { Rating }\end{array}$ & $\begin{array}{l}\text { Weighted } \\
\text { Rating }\end{array}$ \\
\hline 5 & 0 & 0 \\
\hline
\end{tabular}

\begin{tabular}{|l|l|}
\hline 35 & 254 \\
\hline
\end{tabular}

\section{Comments}

Some significance since no fiber is saved, but this technology enhances the use of recycled fiber in the industry.

Even though cost will be 8-10\% higher than competitive for the pressure sensitive adhesives, the market should be driven by the demand for recycled products and an environmentally

friendly adhesive that facilitates the use of recycled fiber. However, the sparker project is an alternate solution to the stickies problem and is closer to commercialization.

Depends on the ability to increase the use of recycled fiber and to reduce downtime requency.

Only stumbling block is 8 to $10 \%$ higher costs for the PSAs and the potential competition from the sparker project (Replacing Chemicals with Mechanical Alternatives).

EcoSynthetix, Inc. is a technology partner and is willing to go forward with commercialization if pilot runs and a suitable reactor can be demonstrated.

Has some applicability to other products, specifically polystyrenes.

Reduces the use of chemicals as well as potentially increases the use of recycled fiber.

When research started, H.B Fuller was believed to a cationic PSA product, but that appears to not be the case, therefore, this project is leading the industry in this area and offers one method of dealing with "stickies"-- P4 and since this project is nearing commercialization, might reduce the significance of this project.

By eliminating "stickies', one of the major obstacles to increased use of recycled paper is eliminated.

This seems to be good science, at least in the lab. Unless unanticipated problems develop, there should be very limited risks.

No contribution. 


\section{FOREST PRODUCTS INDUSTRY OF THE FUTURE - PORTFOLIO STUDY AND EVALUATION}

\section{0-945 Replacing Chemicals in Recycle Mills}

\begin{tabular}{|c|c|c|c|c|c|c|c|}
\hline 1 & $\begin{array}{l}\text { Sustained forest resource } \\
\text { managenent }\end{array}$ & $\begin{array}{c}\text { N/A or no } \\
\text { Significance } \\
0\end{array}$ & \begin{tabular}{|c|} 
Some \\
Significance \\
1
\end{tabular} & 2 & \begin{tabular}{|c|} 
Moderate \\
Significance \\
3 \\
\end{tabular} & 4 & $\begin{array}{c}\text { High } \\
\text { Significance } \\
5\end{array}$ \\
\hline \multirow[b]{2}{*}{2} & \multirow[b]{2}{*}{$\begin{array}{l}\text { Size and extent of market } \\
\text { for the new technology }\end{array}$} & Very Small & Small & & Medium & & Lange \\
\hline & & 0 & 1 & 2 & 3 & 4 & 5 \\
\hline \multirow{2}{*}{3} & \multirow{2}{*}{ Energy perfornance } & $\begin{array}{l}\text { N/A or no } \\
\text { Significance }\end{array}$ & \begin{tabular}{|c|} 
Some \\
Significance
\end{tabular} & & \begin{tabular}{|l|} 
Moderate \\
Significance
\end{tabular} & & $\begin{array}{l}\text { High } \\
\text { Significance }\end{array}$ \\
\hline & & 0 & 1 & 2 & 3 & 4 & 5 \\
\hline \multirow{2}{*}{4} & \multirow{2}{*}{ Economic attractiveness } & Unattractive & \begin{tabular}{|l|} 
Somewhat \\
Attractive
\end{tabular} & & \begin{tabular}{|l|} 
Attractive \\
\end{tabular} & & $\begin{array}{c}\text { Highly } \\
\text { Atractive }\end{array}$ \\
\hline & & 0 & 1 & 2 & 3 & 4 & 5 \\
\hline \multirow{2}{*}{5} & \multirow{2}{*}{ Tecthology champion } & None & \begin{tabular}{|l|} 
Assigned \\
Champion \\
\end{tabular} & & \begin{tabular}{|c|} 
Independent \\
Champion
\end{tabular} & & \begin{tabular}{|c|} 
Multiple \\
Champions
\end{tabular} \\
\hline & & 0 & 1 & 2 & 3 & 4 & 5 \\
\hline \multirow{2}{*}{6} & \multirow{2}{*}{$\begin{array}{l}\text { Scientific insights derived } \\
\text { from project }\end{array}$} & \begin{tabular}{|l} 
N/A or no \\
Significance
\end{tabular} & \begin{tabular}{|l|} 
Some \\
Significance
\end{tabular} & & \begin{tabular}{|l} 
Moderate \\
Significance
\end{tabular} & & $\begin{array}{l}\text { Hiigh } \\
\text { Significance }\end{array}$ \\
\hline & & 0 & 1 & 2 & 3 & 4 & 5 \\
\hline \multirow{2}{*}{7} & \multirow{2}{*}{$\begin{array}{l}\text { Improved environmental } \\
\text { performance }\end{array}$} & $\begin{array}{l}\text { N/A or no } \\
\text { Significance }\end{array}$ & \begin{tabular}{|c|} 
Some \\
Significance
\end{tabular} & & $\begin{array}{l}\text { Moderate } \\
\text { Significance }\end{array}$ & & $\begin{array}{l}\text { High } \\
\text { Significance }\end{array}$ \\
\hline & & 0 & 1 & 2 & 3 & 4 & 5 \\
\hline \multirow{2}{*}{8} & \multirow{2}{*}{ Technological leadership } & \begin{tabular}{|l|} 
N/A or no \\
Significance
\end{tabular} & \begin{tabular}{|c|} 
Some \\
Significance
\end{tabular} & & \begin{tabular}{|l|} 
Moderate \\
Significance \\
\end{tabular} & & $\begin{array}{l}\text { High } \\
\text { Significance }\end{array}$ \\
\hline & & 0 & 1 & 2 & 3 & 4 & 5 \\
\hline \multirow{2}{*}{9} & \multirow{2}{*}{$\begin{array}{l}\text { Recycled wood and paper } \\
\text { materials }\end{array}$} & $\begin{array}{l}\text { N/A or no } \\
\text { Significance }\end{array}$ & \begin{tabular}{|c|} 
Some \\
Significance
\end{tabular} & & \begin{tabular}{|l|} 
Moderate \\
Signiificance
\end{tabular} & & $\begin{array}{l}\text { High } \\
\text { Significance }\end{array}$ \\
\hline & & 0 & 1 & 2 & 3 & 4 & 5 \\
\hline \multirow{2}{*}{10} & \multirow{2}{*}{ Risk } & High Risk & $\begin{array}{l}\text { Moderate } \\
\text { Risk }\end{array}$ & & \begin{tabular}{|l|} 
Low Risk \\
\end{tabular} & & $\begin{array}{l}\text { Very Low } \\
\text { Risk }\end{array}$ \\
\hline & & 0 & 1 & 2 & 3 & 4 & 5 \\
\hline \multirow{2}{*}{11} & \multirow{2}{*}{ Attemate uses for biomass } & $\begin{array}{l}\text { N/A or no } \\
\text { Significance }\end{array}$ & \begin{tabular}{|c|} 
Some \\
Significance
\end{tabular} & & \begin{tabular}{|l|} 
Moderate \\
Significance
\end{tabular} & & \begin{tabular}{|l} 
High \\
Significance
\end{tabular} \\
\hline & & 0 & 1 & 2 & 3 & 4 & 5 \\
\hline
\end{tabular}

Totals

\section{Comments}

\begin{tabular}{|c|c|c|}
\hline $\begin{array}{c}\text { Cro } \\
\text { Weighting }\end{array}$ & $\begin{array}{l}\text { Raw } \\
\text { Rating }\end{array}$ & $\begin{array}{c}\text { Weighted } \\
\text { Rating }\end{array}$ \\
\hline 10 & 1 & 10 \\
\hline $\begin{array}{c}\text { CTO } \\
\text { Weighting }\end{array}$ & $\begin{array}{c}\text { Raw } \\
\text { Rating }\end{array}$ & $\begin{array}{c}\text { Weighted } \\
\text { Rating }\end{array}$ \\
\hline 9 & 5 & 45 \\
\hline $\begin{array}{c}\text { CTO } \\
\text { Weighting }\end{array}$ & $\begin{array}{c}\text { Raw } \\
\text { Rating }\end{array}$ & $\begin{array}{c}\text { Weighted } \\
\text { Rating }\end{array}$ \\
\hline 8 & 3 & 24 \\
\hline $\begin{array}{c}\text { CTO } \\
\text { Weighting }\end{array}$ & $\begin{array}{c}\text { Raw } \\
\text { Rating }\end{array}$ & $\begin{array}{c}\text { Weighted } \\
\text { Rating }\end{array}$ \\
\hline 8 & 5 & 40 \\
\hline $\begin{array}{c}\text { CTO } \\
\text { Weighting }\end{array}$ & $\begin{array}{c}\text { Raw } \\
\text { Rating }\end{array}$ & $\begin{array}{c}\text { Weighted } \\
\text { Rating }\end{array}$ \\
\hline 7 & 4 & 28 \\
\hline $\begin{array}{c}\text { CTO } \\
\text { Weighting }\end{array}$ & $\begin{array}{c}\text { Raw } \\
\text { Rating }\end{array}$ & $\begin{array}{c}\text { Weighted } \\
\text { Rating }\end{array}$ \\
\hline 7 & 3 & 21 \\
\hline $\begin{array}{c}\text { CTO } \\
\text { Weighting }\end{array}$ & $\begin{array}{l}\text { Raw } \\
\text { Rating }\end{array}$ & $\begin{array}{c}\text { Weighted } \\
\text { Rating }\end{array}$ \\
\hline 7 & 4 & 28 \\
\hline $\begin{array}{c}\text { CT̃o } \\
\text { Weighting }\end{array}$ & $\begin{array}{c}\text { Raw } \\
\text { Rating }\end{array}$ & $\begin{array}{c}\text { Weighted } \\
\text { Rating }\end{array}$ \\
\hline 7 & 3 & 21 \\
\hline $\begin{array}{c}\text { CTO } \\
\text { Weighting }\end{array}$ & $\begin{array}{l}\text { Raw } \\
\text { Rating }\end{array}$ & $\begin{array}{c}\text { Weighted } \\
\text { Rating }\end{array}$ \\
\hline 6 & 5 & 30 \\
\hline $\begin{array}{c}\text { CTO } \\
\text { Weighting }\end{array}$ & $\begin{array}{c}\text { Raw } \\
\text { Rating }\end{array}$ & \begin{tabular}{|c} 
Weighted \\
Rating
\end{tabular} \\
\hline 6 & 3 & 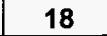 \\
\hline \begin{tabular}{|c|} 
CTO \\
weighting
\end{tabular} & $\begin{array}{c}\text { Raw } \\
\text { Rating }\end{array}$ & $\begin{array}{c}\text { Weighted } \\
\text { Rating }\end{array}$ \\
\hline 5 & 0 & 0 \\
\hline
\end{tabular}

There is some significance to Sustainable Forestry because the higher recovery of recycled products ultimately results in lowered required annual harvests.

PI thinks ultimate market is greater that that stated in GPRA sheet. Success with biocide effects will make this attractive to many process industries outside the paper industry.

Estimated energy savings of 41 million $\mathrm{kWh}$ per installation.

Units are comparatively low cost and are expected to have a very short payback.

Sparktec, Inc. has signed a license agreement to sell the device for the stickies application and presumably for other applications, and potential installations are moving forward.

Effective range of biocidal effects, effect of charge balance on particle agglomeration, effect on sheet quality (brightness, hole count, de-tackifying pitch on metal surfaces).

Lowered chemical usage, potentially lowered biocide usage if effect range issues can be resolved or managed, more materials recycled resulting in lowered solid waste space requirements, $10 \%$ lower water usage. Accomplishes the desired result at lower capital and operating cost. Advancement of mill closure procedures by reducing/elimination of residual chemical build-up.

Lowered production cost, maintenance cost, higher up-time rates from reduction of pitch coating and stickies deposition, more efficient fiber refining.

Removing "stickies" with the new technology will lower cost of recycled products and make them more competitive. Higher quality paper (brightness and lower hole count) will enhance market potential for recycled products.

Ultimately, low to very low risk in proper installation and use of this technology. Necessity of doing all work in mill trials has created some experimental control issue that will ultimately be resolved as more trials are done.

No contribution. 
FOREST PRODUCTS INDUSTRY OF THE FUTURE - PORTFOLIO STUDY AND EVALUATION

31-1198 Surfactant Spray to Improve Flotation Deinking

\begin{tabular}{|c|c|c|c|c|c|c|c|}
\hline 1 & $\begin{array}{l}\text { Sustained forest resource } \\
\text { management }\end{array}$ & \begin{tabular}{|c|} 
N/A or no \\
Significance \\
0 \\
\end{tabular} & \begin{tabular}{|c|} 
Some \\
Significance \\
1 \\
\end{tabular} & 2 & \begin{tabular}{|c|}
$\begin{array}{c}\text { Moderate } \\
\text { Significance } \\
3\end{array}$ \\
\end{tabular} & 4 & $\begin{array}{c}\text { Aigh } \\
\text { Significance } \\
5\end{array}$ \\
\hline 2 & \begin{tabular}{|} 
Size and extent of markst \\
for the new technology
\end{tabular} & $\begin{array}{c}\text { Very Small } \\
0\end{array}$ & $\begin{array}{c}\text { Small } \\
1\end{array}$ & 2 & $\begin{array}{c}\text { Medium } \\
3\end{array}$ & 4 & $\begin{array}{l}\text { Large } \\
5\end{array}$ \\
\hline 3 & Energy perfomance & \begin{tabular}{|c|} 
N/A or no \\
Significance \\
0 \\
0
\end{tabular} & \begin{tabular}{|c|} 
Some \\
Significance \\
1 \\
\end{tabular} & 2 & \begin{tabular}{|c|} 
Moderate \\
Significance \\
3 \\
\end{tabular} & 4 & 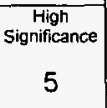 \\
\hline 4 & Economic attractiveness & $\begin{array}{c}\text { Unattractive } \\
0\end{array}$ & \begin{tabular}{|c|} 
Somewhat \\
Atractive \\
1
\end{tabular} & 2 & $\begin{array}{c}\text { Attractive } \\
3\end{array}$ & 4 & $\begin{array}{c}\begin{array}{c}\text { Hightly } \\
\text { Attractive } \\
5\end{array} \\
5\end{array}$ \\
\hline 5 & Technology champion & $\begin{array}{c}\text { None } \\
0\end{array}$ & \begin{tabular}{|c|} 
Assigned \\
Champion \\
1 \\
\end{tabular} & 2 & \begin{tabular}{|c|} 
Independent \\
Champion \\
3 \\
\end{tabular} & 4 & $\begin{array}{c}\text { Multiple } \\
\text { Champions } \\
5\end{array}$ \\
\hline 6 & $\begin{array}{l}\text { Scientific insignts derived } \\
\text { frrom project }\end{array}$ & \begin{tabular}{|c|} 
N/A or no \\
Significance \\
0 \\
\end{tabular} & \begin{tabular}{|c|} 
Some \\
Significance \\
1 \\
1
\end{tabular} & 2 & \begin{tabular}{|c|}
$\begin{array}{c}\text { Moderate } \\
\text { Significance } \\
3\end{array}$ \\
\end{tabular} & 4 & $\begin{array}{c}\text { High } \\
\text { Significance } \\
5 \\
5\end{array}$ \\
\hline 7 & $\begin{array}{l}\text { Improved environmental } \\
\text { performance }\end{array}$ & \begin{tabular}{|c|} 
N/A or no \\
Significance \\
0 \\
0
\end{tabular} & \begin{tabular}{|c|} 
Some \\
Significance \\
1 \\
1
\end{tabular} & 2 & \begin{tabular}{|c|} 
Moderate \\
Significance \\
3 \\
\end{tabular} & 4 & $\begin{array}{c}\text { High } \\
\text { Significance } \\
5\end{array}$ \\
\hline 8 & Tectnological leadership & \begin{tabular}{|c|} 
N/A or $n o$ \\
Significance \\
0 \\
0
\end{tabular} & \begin{tabular}{|c|} 
Some \\
Significance \\
1 \\
1
\end{tabular} & 2 & \begin{tabular}{|c|} 
Moderate \\
Significance \\
3 \\
\end{tabular} & 4 & $\begin{array}{c}\text { High } \\
\text { Significance } \\
5 \\
5\end{array}$ \\
\hline 9 & $\begin{array}{l}\text { Recyded wood and paper } \\
\text { materials }\end{array}$ & $\begin{array}{c}\text { N/A or no } \\
\text { Significance } \\
0\end{array}$ & \begin{tabular}{|c|} 
Some \\
significance \\
1
\end{tabular} & 2 & \begin{tabular}{|c|} 
Moderate \\
Significance \\
3 \\
\end{tabular} & 4 & \begin{tabular}{|c|}
$\begin{array}{c}\text { High } \\
\text { Significance }\end{array}$ \\
5
\end{tabular} \\
\hline 10 & Risk & $\begin{array}{c}\text { Figh Risk } \\
0\end{array}$ & $\begin{array}{c}\begin{array}{c}\text { Moderate } \\
\text { Risk }\end{array} \\
1\end{array}$ & 2 & $\begin{array}{c}\text { Low Risk } \\
3\end{array}$ & 4 & $\begin{array}{c}\text { Ver Low } \\
\text { Risk } \\
5\end{array}$ \\
\hline 11 & Attemate uses for biomass & \begin{tabular}{|c} 
N/A o r no \\
Significance \\
0
\end{tabular} & $\begin{array}{c}\text { Some } \\
\text { Significance } \\
1\end{array}$ & 2 & \begin{tabular}{|c|} 
Moderate \\
Significance \\
3 \\
\end{tabular} & 4 & \begin{tabular}{|c|}
$\begin{array}{c}\text { High } \\
\text { Significance } \\
5 \\
5\end{array}$ \\
\end{tabular} \\
\hline
\end{tabular}

Totals

\begin{tabular}{|c|c|c|}
\hline $\begin{array}{c}\text { cTo } \\
\text { Weighting }\end{array}$ & $\begin{array}{l}\text { Raw } \\
\text { Rating }\end{array}$ & $\begin{array}{l}\text { Weighted } \\
\text { Rating }\end{array}$ \\
\hline 10 & 1 & 10 \\
\hline $\begin{array}{l}\text { CTO } \\
\text { Weighting }\end{array}$ & $\begin{array}{c}\begin{array}{c}\text { Raw } \\
\text { Rating }\end{array} \\
\end{array}$ & $\begin{array}{l}\begin{array}{l}\text { Weighted } \\
\text { Rating }\end{array} \\
\text { a }\end{array}$ \\
\hline 9 & 4 & 36 \\
\hline $\begin{array}{c}\text { CTO } \\
\text { Weighting }\end{array}$ & $\begin{array}{c}\text { Raw } \\
\text { Rating }\end{array}$ & $\begin{array}{c}\begin{array}{c}\text { Weighted } \\
\text { Rating }\end{array} \\
\text { a }\end{array}$ \\
\hline 8 & 5 & 40 \\
\hline $\begin{array}{c}\text { CTO } \\
\text { Weighting }\end{array}$ & $\begin{array}{l}\text { Raw } \\
\text { Rating }\end{array}$ & $\begin{array}{c}\text { Weighted } \\
\text { Rating }\end{array}$ \\
\hline 8 & 4 & 32 \\
\hline $\begin{array}{c}\text { CTO } \\
\text { Weighting }\end{array}$ & $\begin{array}{l}\text { Raw } \\
\text { Rating }\end{array}$ & $\begin{array}{c}\text { Weighted } \\
\text { Rating }\end{array}$ \\
\hline 7 & 3 & 21 \\
\hline $\begin{array}{c}\text { CTO } \\
\text { Weighting }\end{array}$ & $\begin{array}{c}\text { Raw } \\
\text { Rating }\end{array}$ & $\begin{array}{c}\begin{array}{c}\text { Weighted } \\
\text { Rating }\end{array} \\
\text { (a) }\end{array}$ \\
\hline 7 & 1 & 7 \\
\hline $\begin{array}{c}\text { CTO } \\
\text { Weighting }\end{array}$ & $\begin{array}{c}\text { Raw } \\
\text { Rating }\end{array}$ & $\begin{array}{c}\text { Weighted } \\
\text { Rating }\end{array}$ \\
\hline 7 & 2 & 14 \\
\hline \begin{tabular}{|c|} 
CTO \\
Weighting
\end{tabular} & $\begin{array}{c}\text { Raw } \\
\text { Rating }\end{array}$ & $\begin{array}{c}\text { Weighted } \\
\text { Rating }\end{array}$ \\
\hline 7 & 2 & 14 \\
\hline \begin{tabular}{|c} 
CTO \\
Weighting
\end{tabular} & $\begin{array}{c}\text { Raw } \\
\text { Rating }\end{array}$ & $\begin{array}{c}\text { Weighted } \\
\text { Rating }\end{array}$ \\
\hline 6 & 4 & 24 \\
\hline \begin{tabular}{|c} 
CTO \\
Weighting
\end{tabular} & $\begin{array}{c}\text { Raw } \\
\text { Rating }\end{array}$ & $\begin{array}{c}\text { Weighted } \\
\text { Rating }\end{array}$ \\
\hline 6 & 4 & 24 \\
\hline \begin{tabular}{|c|c} 
CTO \\
Weighting
\end{tabular} & $\begin{array}{c}\text { Raw } \\
\text { Rating }\end{array}$ & $\begin{array}{c}\text { Weighted } \\
\text { Rating }\end{array}$ \\
\hline 5 & 0 & 0 \\
\hline
\end{tabular}

\begin{tabular}{|l|l|}
\hline 30 & 222 \\
\hline
\end{tabular}

\section{Comments}

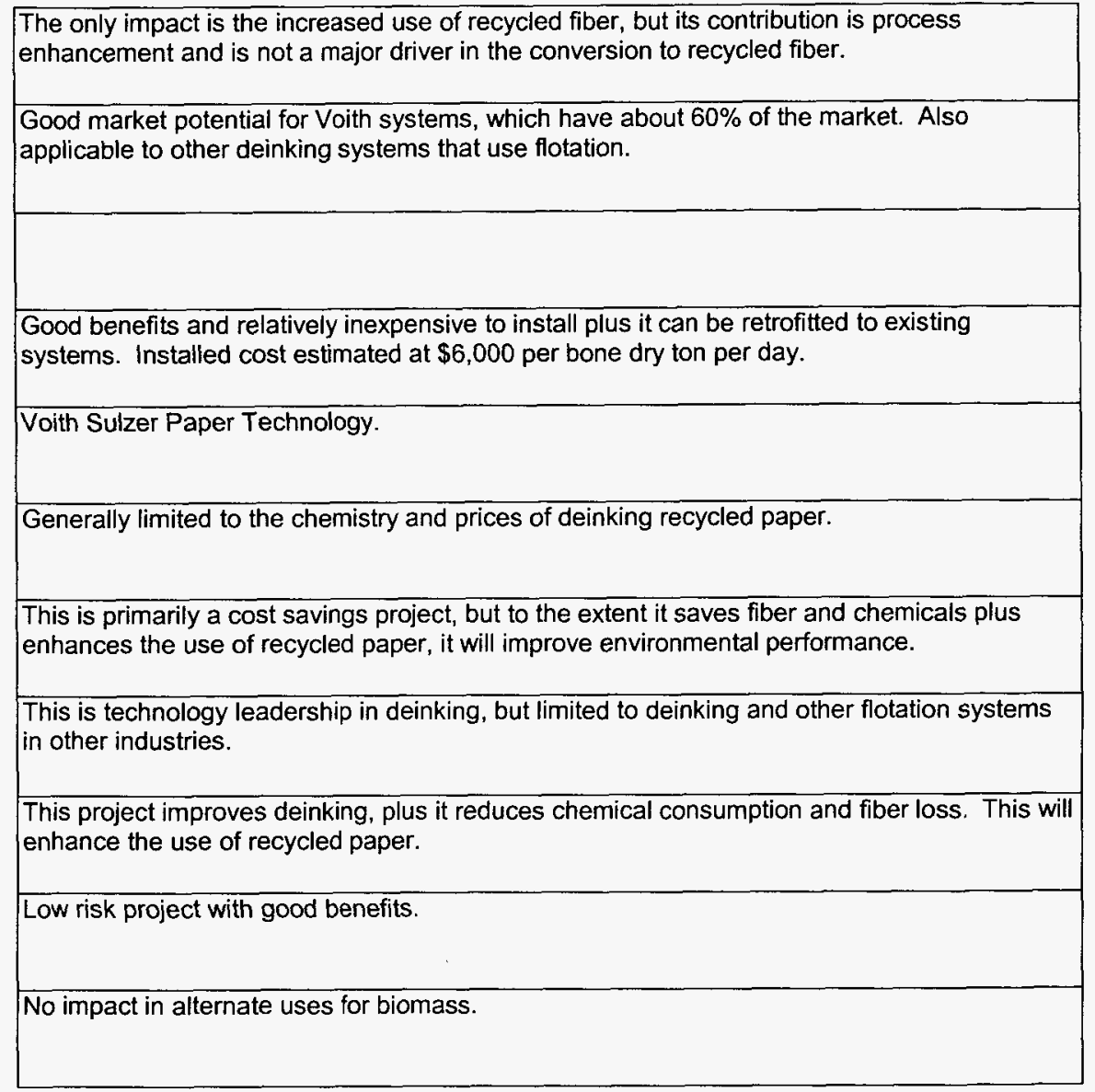




\section{2-1158/699 Feed Stock-Product/Field Mobile NIR}

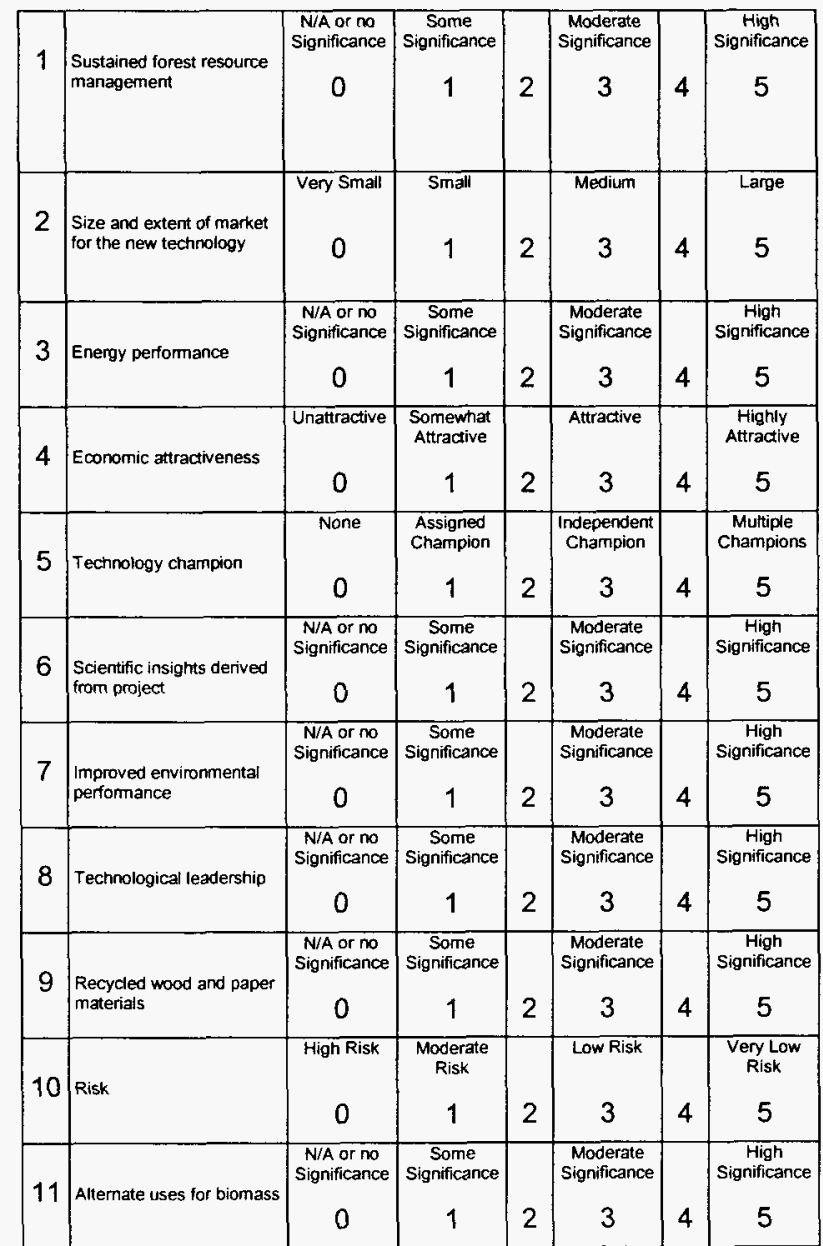

Totals

\begin{tabular}{|c|c|c|}
\hline $\begin{array}{c}\text { CTO } \\
\text { Weighting }\end{array}$ & $\begin{array}{c}\text { Raw } \\
\text { Rating }\end{array}$ & $\begin{array}{c}\text { Weighted } \\
\text { Rating }\end{array}$ \\
\hline 10 & 2 & 20 \\
\hline $\begin{array}{c}\text { CTO } \\
\text { Weighting }\end{array}$ & $\begin{array}{c}\text { Raw } \\
\text { Rating }\end{array}$ & $\begin{array}{c}\text { Weighted } \\
\text { Rating }\end{array}$ \\
\hline 9 & 5 & 45 \\
\hline $\begin{array}{c}\text { CTO } \\
\text { Weighting }\end{array}$ & $\begin{array}{c}\text { Raw } \\
\text { Rating }\end{array}$ & $\begin{array}{c}\text { Weighted } \\
\text { Rating }\end{array}$ \\
\hline 8 & 1 & 8 \\
\hline $\begin{array}{c}\text { CTO } \\
\text { Weighting }\end{array}$ & $\begin{array}{c}\text { Raw } \\
\text { Rating }\end{array}$ & $\begin{array}{c}\text { Weighted } \\
\text { Rating }\end{array}$ \\
\hline 8 & 5 & 40 \\
\hline $\begin{array}{c}\text { CTO } \\
\text { Weighting }\end{array}$ & $\begin{array}{c}\text { Raw } \\
\text { Rating }\end{array}$ & $\begin{array}{c}\text { Weighted } \\
\text { Rating }\end{array}$ \\
\hline 7 & 5 & 35 \\
\hline $\begin{array}{c}\text { CTO } \\
\text { Weighting }\end{array}$ & $\begin{array}{c}\text { Raw } \\
\text { Rating }\end{array}$ & \begin{tabular}{|c} 
Weighted \\
Rating
\end{tabular} \\
\hline 7 & 5 & 35 \\
\hline $\begin{array}{c}\text { CTO } \\
\text { Weighting }\end{array}$ & $\begin{array}{c}\text { Raw } \\
\text { Rating }\end{array}$ & $\begin{array}{l}\text { Weighted } \\
\text { Rating }\end{array}$ \\
\hline 7 & 1 & 7 \\
\hline $\begin{array}{c}\text { CTO } \\
\text { Weighting }\end{array}$ & $\begin{array}{c}\text { Raw } \\
\text { Rating }\end{array}$ & $\begin{array}{l}\text { Weighted } \\
\text { Rating }\end{array}$ \\
\hline 7 & 5 & 35 \\
\hline $\begin{array}{c}\text { CTO } \\
\text { Weighting }\end{array}$ & $\begin{array}{c}\text { Raw } \\
\text { Rating }\end{array}$ & $\begin{array}{c}\text { Weighted } \\
\text { Rating }\end{array}$ \\
\hline 6 & 4 & 24 \\
\hline $\begin{array}{c}\text { CTO } \\
\text { Weighting }\end{array}$ & $\begin{array}{c}\text { Raw } \\
\text { Rating }\end{array}$ & $\begin{array}{c}\text { Weighted } \\
\text { Rating }\end{array}$ \\
\hline 6 & 4 & 24 \\
\hline $\begin{array}{c}\text { CTO } \\
\text { Weighting }\end{array}$ & $\begin{array}{c}\text { Raw } \\
\text { Rating }\end{array}$ & $\begin{array}{c}\text { Weighted } \\
\text { Rating }\end{array}$ \\
\hline 5 & 4 & 20 \\
\hline
\end{tabular}

Relationship to this area is primarily as a tool used in research efforts. Its significance is more than being a new tool because the understanding of wood chemical and physical properties in standing timber on a virtually instantaneous basis brings a new level of information about the effects of forest management practices and can affect the decision cycle times in sustainable forestry research.

Technology has demonstrated applications in forestry, wood processing, and pulp production. PI believes there are other crossover applications in recycling paper and treated wood products. There may be other non-forest products applications. Relatively low cost will expand the market.

Not a primary objective of the research. Energy benefits will come from lowered process energy required for the wood because of better-defined sorting characteristics.

\section{Probable unit cost of less than $\$ 10,000$ makes this a very attractive device for forestry} research. Integrated application in processing should also be reasonably priced and attractive.

Ron Brown Westvaco, Peter Arranson Weyerhaeuser, Allistair Twaddle, IP.

Development of correlation of NIR Spectral data with physical and chemical properties is highly significant.

High, received R\&D 100 award.

Moderate to High significance because of ability to sort on chemical and physical properties.

Low to both project successful completion and to commercialization.

Ability to know chemical compositions quickly cheaply and at various stages in the growth and harvesting of biomass materials. 


\section{FOREST PRODUCTS INDUSTRY OF THE FUTURE - PORTFOLIO STUDY AND EVALUATION}

\section{3-827 Distributed Web Sensor for On-Line Measurement of Paper} Basis Weight

\begin{tabular}{|c|c|c|c|c|c|c|c|}
\hline 1 & $\begin{array}{l}\text { Sustained forest resource } \\
\text { management }\end{array}$ & \begin{tabular}{|c} 
N/A or no \\
Significance \\
0 \\
0
\end{tabular} & \begin{tabular}{|c|} 
Some \\
Significance \\
1 \\
1
\end{tabular} & 2 & \begin{tabular}{|c|}
$\begin{array}{c}\text { Moderate } \\
\text { Significance } \\
3\end{array}$ \\
\end{tabular} & 4 & \begin{tabular}{|c|} 
High \\
Significance \\
5
\end{tabular} \\
\hline 2 & $\begin{array}{l}\text { Size and extent of market } \\
\text { for the new technology }\end{array}$ & $\begin{array}{c}\text { Very Small } \\
0\end{array}$ & $\begin{array}{c}\text { Small } \\
1\end{array}$ & 2 & $\begin{array}{c}\text { Medium } \\
3\end{array}$ & 4 & $\begin{array}{l}\text { Lange } \\
5\end{array}$ \\
\hline 3 & Energy performance & $\begin{array}{c}\text { N/A o mo } \\
\text { Significance } \\
0 \\
0\end{array}$ & \begin{tabular}{|c|} 
Some \\
Significance \\
1
\end{tabular} & 2 & \begin{tabular}{|c|} 
Moderate \\
Significance \\
3 \\
\end{tabular} & 4 & $\begin{array}{c}\text { High } \\
\text { Significance } \\
5\end{array}$ \\
\hline 4 & Economic attractiveness & \begin{tabular}{|c} 
Unattractive \\
0 \\
0
\end{tabular} & $\begin{array}{c}\text { Somewhat } \\
\text { Attractive } \\
1\end{array}$ & 2 & $\begin{array}{c}\text { Attractive } \\
3\end{array}$ & 4 & $\begin{array}{c}\text { Highly } \\
\text { Atractive } \\
5\end{array}$ \\
\hline 5 & Technology champion & $\begin{array}{l}\text { None } \\
0\end{array}$ & $\begin{array}{c}\begin{array}{c}\text { Assigned } \\
\text { Champion } \\
1\end{array} \\
1\end{array}$ & 2 & \begin{tabular}{|c|} 
Independeent \\
Champion \\
3
\end{tabular} & 4 & $\begin{array}{c}\text { Mutriple } \\
\text { Champions } \\
5\end{array}$ \\
\hline 6 & $\begin{array}{l}\text { Scientific insights derived } \\
\text { trom project }\end{array}$ & \begin{tabular}{|c|} 
N/A or no \\
Significance \\
0 \\
0
\end{tabular} & \begin{tabular}{|c|} 
Some \\
Significance \\
1 \\
1
\end{tabular} & 2 & \begin{tabular}{|c|} 
Moderate \\
significance \\
3 \\
\end{tabular} & 4 & $\begin{array}{c}\text { High } \\
\text { Significance } \\
5 \\
5\end{array}$ \\
\hline 7 & $\begin{array}{l}\text { Improved environmental } \\
\text { performance }\end{array}$ & \begin{tabular}{|c|} 
N/A or no \\
Significance \\
0 \\
0
\end{tabular} & \begin{tabular}{|c|} 
Some \\
Significance \\
1 \\
1
\end{tabular} & 2 & \begin{tabular}{|c|} 
Moderate \\
Significance \\
3
\end{tabular} & 4 & $\begin{array}{c}\text { High } \\
\text { Significance } \\
5 \\
5\end{array}$ \\
\hline 8 & Technological leadership & \begin{tabular}{|c|} 
N/A or no \\
Significance \\
0 \\
0
\end{tabular} & \begin{tabular}{|c|} 
Some \\
Significance \\
1 \\
1
\end{tabular} & 2 & \begin{tabular}{|c|} 
Moderate \\
Significance \\
3 \\
\end{tabular} & 4 & $\begin{array}{c}\text { High } \\
\text { Significance } \\
5\end{array}$ \\
\hline 9 & $\begin{array}{l}\begin{array}{l}\text { Recycled wood and paper } \\
\text { materials }\end{array} \\
\text { ing }\end{array}$ & \begin{tabular}{|c} 
N/A or no \\
Significance \\
0 \\
0
\end{tabular} & \begin{tabular}{|c|} 
Some \\
significance \\
1 \\
1
\end{tabular} & 2 & \begin{tabular}{|c|} 
Moderate \\
Significance \\
3 \\
\end{tabular} & 4 & \begin{tabular}{|c} 
High \\
Significance \\
5
\end{tabular} \\
\hline 10 & Risk & \begin{tabular}{|c} 
High Risk \\
0
\end{tabular} & $\begin{array}{c}\begin{array}{c}\text { Moderate } \\
\text { Risk }\end{array} \\
1\end{array}$ & 2 & $\begin{array}{c}\text { Low Risk } \\
3\end{array}$ & 4 & $\begin{array}{c}\begin{array}{c}\text { Very Low } \\
\text { Risk }\end{array} \\
5\end{array}$ \\
\hline 11 & Alternate uses for biomass & \begin{tabular}{|c|} 
N/A or no \\
Significance \\
0 \\
0
\end{tabular} & \begin{tabular}{|c|} 
Some \\
significance \\
1
\end{tabular} & 2 & \begin{tabular}{|c|} 
Moderate \\
Significance \\
3 \\
\end{tabular} & 4 & $\begin{array}{c}\text { High } \\
\text { Significance } \\
5\end{array}$ \\
\hline
\end{tabular}

\begin{tabular}{|c|c|c|}
\hline $\begin{array}{c}\text { CTO } \\
\text { Weighting }\end{array}$ & $\begin{array}{l}\text { Raw } \\
\text { Rating }\end{array}$ & $\begin{array}{c}\text { Weighted } \\
\text { Rating }\end{array}$ \\
\hline 10 & 0 & 0 \\
\hline $\begin{array}{c}\text { CTO } \\
\text { Weighting }\end{array}$ & $\begin{array}{l}\text { Raw } \\
\text { Rating }\end{array}$ & $\begin{array}{c}\text { Weighted } \\
\text { Rating }\end{array}$ \\
\hline 9 & 1 & 9 \\
\hline $\begin{array}{c}\text { CTO } \\
\text { Weighting }\end{array}$ & $\begin{array}{l}\text { Raw } \\
\text { Rating }\end{array}$ & $\begin{array}{c}\text { Weighted } \\
\text { Rating }\end{array}$ \\
\hline 8 & 1 & 8 \\
\hline $\begin{array}{c}\text { CTO } \\
\text { Weighting }\end{array}$ & $\begin{array}{l}\text { Raw } \\
\text { Rating }\end{array}$ & $\begin{array}{c}\text { Weighted } \\
\text { Rating }\end{array}$ \\
\hline 8 & 0 & 0 \\
\hline $\begin{array}{c}\text { CTO } \\
\text { Weighting }\end{array}$ & $\begin{array}{l}\text { Raw } \\
\text { Rating }\end{array}$ & $\begin{array}{c}\text { Weighted } \\
\text { Rating }\end{array}$ \\
\hline 7 & 0 & 0 \\
\hline $\begin{array}{c}\text { CTO } \\
\text { Weighting }\end{array}$ & $\begin{array}{l}\text { Raw } \\
\text { Rating }\end{array}$ & $\begin{array}{l}\text { Weighted } \\
\text { Rating }\end{array}$ \\
\hline 7 & 2 & 14 \\
\hline $\begin{array}{c}\text { CTO } \\
\text { Weighting }\end{array}$ & $\begin{array}{l}\text { Raw } \\
\text { Rating }\end{array}$ & $\begin{array}{c}\text { Weighted } \\
\text { Rating }\end{array}$ \\
\hline 7 & 0 & 0 \\
\hline $\begin{array}{c}\text { CTOO } \\
\text { Weighting }\end{array}$ & $\begin{array}{l}\text { Raw } \\
\text { Rating }\end{array}$ & $\begin{array}{c}\text { Weighted } \\
\text { Rating }\end{array}$ \\
\hline 7 & 1 & 7 \\
\hline $\begin{array}{c}\text { CTO } \\
\text { Weighting }\end{array}$ & $\begin{array}{l}\text { Raw } \\
\text { Rating }\end{array}$ & $\begin{array}{c}\text { Weighted } \\
\text { Rating }\end{array}$ \\
\hline 6 & 0 & 0 \\
\hline $\begin{array}{c}\text { CTO } \\
\text { Weighting }\end{array}$ & $\begin{array}{l}\text { Raw } \\
\text { Rating }\end{array}$ & $\begin{array}{c}\text { Weighted } \\
\text { Rating }\end{array}$ \\
\hline 6 & 1 & 6 \\
\hline $\begin{array}{c}\text { CTO } \\
\text { Weighting }\end{array}$ & $\begin{array}{l}\text { Raw } \\
\text { Rating }\end{array}$ & \begin{tabular}{|c|}
$\begin{array}{c}\text { Weighted } \\
\text { Rating }\end{array}$ \\
\end{tabular} \\
\hline 5 & 0 & 0 \\
\hline
\end{tabular}

Totals

\section{Comments}

There does not appear to be any affect on forest resources.

The market could be fairly large if there were a demand for this particular technology. The $\mathrm{Pl}$ indicated that the slow response time (10's of seconds) was a factor in poor attractiveness in the market. The Co-Chair for these projects noted that this full web weight basis measurement device was desired by the industry. No measurable affect on energy consumption/savings.

There is a low level of economic attractiveness. The PI commented that it would take another $\$ 1-\$ 5$ million to prepare for market.

ABB Industrial Systems Inc. was the main support for this project.

After Progressing through the steps of this project, I believe the research team learned some of the limitations of this technology and maybe there is a use for this type of density measurement in some other market that would better match this systems' performance. Use of radioactive elements.

1 could see some demand for a system that performed a real-time measurement of the paper web density, but this proposed system has some drawbacks (slow measurement speed and radioactive components).

Not applicable.

A lot more money would have to be invested in development and commercialization of this technology. The current point source method works. Other methods are also being looked at.

Not applicable. 


\section{FOREST PRODUCTS INDUSTRY OF THE FUTURE - PORTFOLIO STUDY AND EVALUATION}

\section{4-975 On-Line Fluidics Controlled Headbox}

\begin{tabular}{|c|c|c|c|c|c|c|c|}
\hline 1 & $\begin{array}{l}\text { Sustained forest resource } \\
\text { management }\end{array}$ & \begin{tabular}{|c|} 
N/A or no \\
Significance \\
0 \\
0
\end{tabular} & \begin{tabular}{|c|} 
Some \\
Significance \\
1 \\
1
\end{tabular} & 2 & $\begin{array}{c}\text { Moderate } \\
\text { Significance } \\
3\end{array}$ & 4 & \begin{tabular}{|c|} 
High \\
Significance \\
5 \\
5
\end{tabular} \\
\hline 2 & \begin{tabular}{|l|} 
Size and extent of market \\
for the new technology
\end{tabular} & \begin{tabular}{|c|} 
Very Small \\
0
\end{tabular} & $\begin{array}{c}\text { Small } \\
1\end{array}$ & 2 & $\begin{array}{c}\text { Medium } \\
3\end{array}$ & 4 & $\begin{array}{l}\text { Large } \\
5\end{array}$ \\
\hline 3 & Energy performance & \begin{tabular}{|c|} 
N/A or no \\
Significance \\
0 \\
\end{tabular} & \begin{tabular}{|c|} 
Some \\
Significance \\
1 \\
1
\end{tabular} & 2 & $\begin{array}{c}\text { Moderate } \\
\text { Significance } \\
3 \\
3\end{array}$ & 4 & \begin{tabular}{|c|}
$\begin{array}{c}\text { High } \\
\text { Significance } \\
5\end{array}$ \\
\end{tabular} \\
\hline 4 & Economic attractiveness & $\begin{array}{c}\text { Unattractive } \\
0\end{array}$ & \begin{tabular}{|c|} 
Somewhat \\
Atractive \\
1 \\
\end{tabular} & 2 & $\begin{array}{c}\text { Attractive } \\
3 \\
3\end{array}$ & 4 & 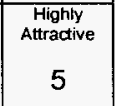 \\
\hline 5 & Techrology champion & $\begin{array}{c}\text { None } \\
0 \\
0\end{array}$ & \begin{tabular}{|c|} 
Assigned \\
champion \\
1 \\
\end{tabular} & 2 & $\begin{array}{c}\begin{array}{c}\text { Independent } \\
\text { Champion } \\
3\end{array} \\
\end{array}$ & 4 & \begin{tabular}{|c|}
$\begin{array}{c}\text { Multiple } \\
\text { Champions }\end{array}$ \\
5
\end{tabular} \\
\hline 6 & $\begin{array}{l}\text { Scientific insights defived } \\
\text { from project }\end{array}$ & \begin{tabular}{|c|} 
N/A or no \\
Significance \\
0 \\
0
\end{tabular} & \begin{tabular}{|c|} 
Some \\
Significance \\
1 \\
1
\end{tabular} & 2 & \begin{tabular}{|c|} 
Moderate \\
significance \\
3 \\
\end{tabular} & 4 & \begin{tabular}{|c|} 
High \\
Significance \\
5 \\
5
\end{tabular} \\
\hline 7 & $\begin{array}{l}\text { Improved environmental } \\
\text { performance }\end{array}$ & \begin{tabular}{|c|} 
N/A or no \\
Significance \\
0 \\
\end{tabular} & \begin{tabular}{|c|} 
Some \\
Significance \\
1 \\
\end{tabular} & 2 & \begin{tabular}{|c|} 
Moderate \\
Significance \\
3 \\
3
\end{tabular} & 4 & \begin{tabular}{|c|}
$\begin{array}{c}\text { High } \\
\text { Significance } \\
5\end{array}$ \\
\end{tabular} \\
\hline 8 & Technological leadership & \begin{tabular}{|c|} 
N/A or no \\
Significance \\
0 \\
\end{tabular} & \begin{tabular}{|c|} 
Some \\
Significance \\
1 \\
\end{tabular} & 2 & \begin{tabular}{|c|} 
Moderate \\
Significance \\
3 \\
\end{tabular} & 4 & \begin{tabular}{|c|} 
High \\
Significance \\
5 \\
\end{tabular} \\
\hline 9 & $\begin{array}{l}\text { Recycled wood and paper } \\
\text { materials }\end{array}$ & \begin{tabular}{|c|} 
N/A or no \\
Significance \\
0 \\
\end{tabular} & \begin{tabular}{|c|} 
Some \\
Significance \\
1
\end{tabular} & 2 & \begin{tabular}{|c|} 
Moderate \\
Significance \\
3 \\
\end{tabular} & 4 & \begin{tabular}{|c|}
$\begin{array}{c}\text { High } \\
\text { Significance } \\
5\end{array}$ \\
\end{tabular} \\
\hline 10 & Risk & $\begin{array}{c}\text { Hign Risk } \\
0\end{array}$ & $\begin{array}{c}\text { Moderate } \\
\text { Risk } \\
1\end{array}$ & 2 & $\begin{array}{c}\text { Low Risk } \\
3\end{array}$ & 4 & $\begin{array}{c}\text { Very Low } \\
\text { Risk } \\
5\end{array}$ \\
\hline 11 & Allemate uses for biomass & \begin{tabular}{|c|} 
N/A or no \\
Significance \\
0 \\
\end{tabular} & \begin{tabular}{|c} 
Some \\
Significance \\
1
\end{tabular} & 2 & \begin{tabular}{|c|} 
Moderate \\
Significance \\
3 \\
\end{tabular} & 4 & \begin{tabular}{|c|}
$\begin{array}{c}\text { High } \\
\text { Significance } \\
5 \\
5\end{array}$ \\
\end{tabular} \\
\hline
\end{tabular}

Totals

\begin{tabular}{|c|c|c|}
\hline $\begin{array}{c}\text { CTO } \\
\text { Weighting }\end{array}$ & $\begin{array}{c}\text { Raw } \\
\text { Rating }\end{array}$ & $\begin{array}{c}\text { Weighted } \\
\text { Rating }\end{array}$ \\
\hline 10 & 4 & 40 \\
\hline \begin{tabular}{|c|} 
CTO \\
Weighting
\end{tabular} & $\begin{array}{c}\text { Raw } \\
\text { Rating }\end{array}$ & $\begin{array}{c}\text { Weighted } \\
\text { Rating }\end{array}$ \\
\hline 9 & 5 & 45 \\
\hline \begin{tabular}{|c|} 
CTO \\
Weighting
\end{tabular} & $\begin{array}{c}\text { Raw } \\
\text { Rating }\end{array}$ & $\begin{array}{l}\text { Weighted } \\
\text { Rating }\end{array}$ \\
\hline 8 & 3 & 24 \\
\hline $\begin{array}{c}\text { CTO } \\
\text { Weighting }\end{array}$ & $\begin{array}{c}\text { Raw } \\
\text { Rating }\end{array}$ & $\begin{array}{c}\text { Weighted } \\
\text { Rating }\end{array}$ \\
\hline 8 & 4 & 32 \\
\hline $\begin{array}{c}\text { CTO } \\
\text { Weighting }\end{array}$ & $\begin{array}{c}\text { Raw } \\
\text { Rating }\end{array}$ & \begin{tabular}{|c} 
Weighted \\
Rating
\end{tabular} \\
\hline 7 & 4 & \\
\hline \begin{tabular}{|c|} 
CTO \\
Weighting
\end{tabular} & $\begin{array}{c}\text { Raw } \\
\text { Rating }\end{array}$ & $\begin{array}{c}\text { Weighted } \\
\text { Rating }\end{array}$ \\
\hline 7 & 4 & \\
\hline $\begin{array}{c}\text { CTO } \\
\text { Weighting }\end{array}$ & $\begin{array}{c}\text { Raw } \\
\text { Rating }\end{array}$ & $\begin{array}{c}\text { Weighted } \\
\text { Rating }\end{array}$ \\
\hline 7 & 3 & \\
\hline $\begin{array}{c}\text { CTO } \\
\text { Weighting }\end{array}$ & $\begin{array}{c}\text { Raw } \\
\text { Rating }\end{array}$ & $\begin{array}{l}\text { Weighted } \\
\text { Rating }\end{array}$ \\
\hline 7 & 3 & \\
\hline $\begin{array}{c}\text { CTO } \\
\text { Weighting }\end{array}$ & $\begin{array}{c}\text { Raw } \\
\text { Rating }\end{array}$ & $\begin{array}{c}\text { Weighted } \\
\text { Rating }\end{array}$ \\
\hline 6 & 0 & 0 \\
\hline $\begin{array}{c}\text { CTO } \\
\text { Weighting }\end{array}$ & $\begin{array}{c}\text { Raw } \\
\text { Rating }\end{array}$ & $\begin{array}{c}\text { Weighted } \\
\text { Rating }\end{array}$ \\
\hline 6 & 3 & \\
\hline $\begin{array}{c}\text { CTO } \\
\text { Weighting }\end{array}$ & $\begin{array}{c}\text { Raw } \\
\text { Rating }\end{array}$ & $\begin{array}{c}\text { Weighted } \\
\text { Rating }\end{array}$ \\
\hline 5 & 0 & \\
\hline
\end{tabular}

By producing a more isotropic distribution of the paper fiber the strength and quality are increased. In the linerboard plants the team indicates a 5-10\% reduction in pulp to produce the same strength linerboard.

The market should be fairly large based on continued successful results.

There are energy savings related to less required fiber. Less fiber, less required drying energy and less energy for refining.

The data results from the commercial trials of the vortigen block with static elements shows several benefits over the standard headbox designs.

Multiple groups involved.

The team is currently looking at options in controlling the vorticity generating elements by

using memory shape metals and other devices.

Better isotropic fiber orientation can lead to a reduction in fiber usage, which in turn would lead to a reduction in the pulping process and a reduction in any environmental problems.

The IPST team has developed some of the fundamental technology behind this research.

Not applicable.

There already is success with the vortigen block with stationary elements setup in the

commercial trials the team has conducted.

Not applicable. 
FOREST PRODUCTS INDUSTRY OF THE FUTURE - PORTFOLIO STUDY AND EVALUATION

35-1157 Guided Acoustic Wave Monitoring of Corrosion \& Erosion in Recovery Boiler Tubing

\begin{tabular}{|c|c|c|c|c|c|c|c|}
\hline 1 & $\begin{array}{l}\text { Sustained forest resource } \\
\text { management }\end{array}$ & \begin{tabular}{|c|} 
N/A or no \\
Significance \\
0 \\
\end{tabular} & $\begin{array}{c}\text { Some } \\
\text { Significance } \\
1\end{array}$ & 2 & \begin{tabular}{|c|}
$\begin{array}{c}\text { Moderate } \\
\text { Significance } \\
3\end{array}$ \\
\end{tabular} & 4 & \begin{tabular}{|c|}
$\begin{array}{c}\text { High } \\
\text { Significance } \\
5 \\
5\end{array}$ \\
\end{tabular} \\
\hline 2 & $\begin{array}{l}\text { Size and extent of market } \\
\text { for the new techrology }\end{array}$ & \begin{tabular}{|c|} 
Very Small \\
0
\end{tabular} & $\begin{array}{c}\text { Small } \\
1\end{array}$ & 2 & $\begin{array}{c}\text { Medium } \\
3\end{array}$ & 4 & $\begin{array}{l}\text { Large } \\
5\end{array}$ \\
\hline 3 & Energy perfornance & \begin{tabular}{|c|} 
N/A or no \\
Significance \\
0 \\
0
\end{tabular} & \begin{tabular}{|c|} 
Some \\
Significance \\
1
\end{tabular} & 2 & \begin{tabular}{|c|} 
Moderate \\
Significance \\
3 \\
\end{tabular} & 4 & $\begin{array}{c}\text { High } \\
\text { Significance } \\
5\end{array}$ \\
\hline 4 & Economic attractiveness & $\begin{array}{c}\text { Unattractive } \\
0\end{array}$ & \begin{tabular}{|c|} 
Somewhat \\
Attractive \\
1
\end{tabular} & 2 & \begin{tabular}{|c|} 
Atractive \\
3
\end{tabular} & 4 & \begin{tabular}{|c} 
Highly \\
Attractive \\
5
\end{tabular} \\
\hline 5 & Technology champion & $\begin{array}{c}\text { None } \\
0\end{array}$ & $\begin{array}{c}\text { Assigned } \\
\text { Champion } \\
1\end{array}$ & 2 & \begin{tabular}{|c|}
$\begin{array}{c}\text { Independent } \\
\text { Cnampion } \\
3\end{array}$ \\
\end{tabular} & 4 & \begin{tabular}{|c} 
Multiple \\
champions \\
5
\end{tabular} \\
\hline 6 & $\begin{array}{l}\text { Scientifc insights derived } \\
\text { trom project }\end{array}$ & \begin{tabular}{|c|} 
N/A or no \\
Significance \\
0 \\
\end{tabular} & \begin{tabular}{|c|} 
Some \\
Significance \\
1
\end{tabular} & 2 & \begin{tabular}{|c|} 
Moderate \\
Significance \\
3 \\
\end{tabular} & 4 & $\begin{array}{c}\text { High } \\
\text { Significance } \\
5\end{array}$ \\
\hline 7 & $\begin{array}{l}\text { Improved environmental } \\
\text { periomance }\end{array}$ & \begin{tabular}{|c|} 
N/A or no \\
Significance \\
0 \\
\end{tabular} & $\begin{array}{c}\text { Some } \\
\text { Significance } \\
1\end{array}$ & 2 & \begin{tabular}{|c|}
$\begin{array}{c}\text { Moderate } \\
\text { Significance } \\
3\end{array}$ \\
\end{tabular} & 4 & $\begin{array}{c}\text { High } \\
\text { Significance } \\
5 \\
5\end{array}$ \\
\hline 8 & Technological leadership & \begin{tabular}{|c|} 
N/A or no \\
significance \\
0 \\
\end{tabular} & $\begin{array}{c}\text { Some } \\
\text { significance } \\
1\end{array}$ & 2 & \begin{tabular}{|c|} 
Moderate \\
Significance \\
3 \\
\end{tabular} & 4 & $\begin{array}{c}\text { High } \\
\text { Significance } \\
5\end{array}$ \\
\hline 9 & $\begin{array}{l}\text { Recycled wood and paper } \\
\text { materials }\end{array}$ & \begin{tabular}{|c|} 
N/A or no \\
Significance \\
0 \\
\end{tabular} & \begin{tabular}{|c|} 
Some \\
significance \\
1
\end{tabular} & 2 & \begin{tabular}{|c|} 
Moderate \\
Significance \\
3 \\
\end{tabular} & 4 & $\begin{array}{c}\text { High } \\
\text { Significance } \\
5\end{array}$ \\
\hline 10 & Risk & $\begin{array}{c}\text { High Risk } \\
0\end{array}$ & $\begin{array}{c}\text { Moderate } \\
\text { Risk } \\
1\end{array}$ & 2 & $\begin{array}{c}\text { Low Risk } \\
3\end{array}$ & 4 & \begin{tabular}{|c}
$\begin{array}{c}\text { Very Low } \\
\text { Risk } \\
5\end{array}$ \\
5
\end{tabular} \\
\hline 11 & Altemate uses for biomass & \begin{tabular}{|c|} 
N/A or no \\
Significance \\
0 \\
\end{tabular} & \begin{tabular}{|c|} 
Some \\
Significance \\
1 \\
\end{tabular} & 2 & \begin{tabular}{|c|} 
Moderate \\
Significance \\
3 \\
\end{tabular} & 4 & \begin{tabular}{|c} 
High \\
Significance \\
5
\end{tabular} \\
\hline
\end{tabular}

Totals

\begin{tabular}{|c|c|c|}
\hline $\begin{array}{c}\text { CTO } \\
\text { Weighting }\end{array}$ & $\begin{array}{c}\text { Raw } \\
\text { Rating }\end{array}$ & $\begin{array}{c}\text { Weighted } \\
\text { Rating }\end{array}$ \\
\hline 10 & 0 & 0 \\
\hline $\begin{array}{l}\text { CTO } \\
\text { Weighting }\end{array}$ & $\begin{array}{l}\text { Raw } \\
\text { Rating }\end{array}$ & $\begin{array}{l}\text { Weighted } \\
\text { Rating }\end{array}$ \\
\hline 9 & 4 & 36 \\
\hline $\begin{array}{c}\text { CTO } \\
\text { Weighting }\end{array}$ & $\begin{array}{c}\text { Raw } \\
\text { Rating }\end{array}$ & $\begin{array}{c}\text { Weighted } \\
\text { Rating }\end{array}$ \\
\hline 8 & 1 & 8 \\
\hline $\begin{array}{c}\text { CTO } \\
\text { Weighting }\end{array}$ & $\begin{array}{c}\text { Raw } \\
\text { Rating }\end{array}$ & $\begin{array}{c}\text { Weighted } \\
\text { Rating }\end{array}$ \\
\hline 8 & 3 & 24 \\
\hline $\begin{array}{c}\text { CTO } \\
\text { Weighting }\end{array}$ & $\begin{array}{c}\text { Raw } \\
\text { Rating }\end{array}$ & $\begin{array}{c}\text { Weighted } \\
\text { Rating }\end{array}$ \\
\hline 7 & 4 & 28 \\
\hline $\begin{array}{c}\text { CTO } \\
\text { Weighting }\end{array}$ & $\begin{array}{c}\text { Raw } \\
\text { Rating }\end{array}$ & $\begin{array}{c}\text { Weighted } \\
\text { Rating }\end{array}$ \\
\hline 7 & 3 & 2 \\
\hline $\begin{array}{c}\text { CTO } \\
\text { Weighting }\end{array}$ & $\begin{array}{c}\text { Raw } \\
\text { Rating }\end{array}$ & $\begin{array}{c}\text { Weighted } \\
\text { Rating }\end{array}$ \\
\hline 7 & 1 & 7 \\
\hline $\begin{array}{c}\text { CTO } \\
\text { Weighting }\end{array}$ & $\begin{array}{c}\text { Raw } \\
\text { Rating }\end{array}$ & $\begin{array}{c}\text { Weighted } \\
\text { Rating }\end{array}$ \\
\hline 7 & 2 & 14 \\
\hline $\begin{array}{c}\text { CTO } \\
\text { Weighting }\end{array}$ & $\begin{array}{c}\text { Raw } \\
\text { Rating }\end{array}$ & $\begin{array}{c}\text { Weighted } \\
\text { Rating }\end{array}$ \\
\hline 6 & 0 & 0 \\
\hline $\begin{array}{c}\text { CTO } \\
\text { Weighting }\end{array}$ & $\begin{array}{l}\text { Raw } \\
\text { Rating }\end{array}$ & \begin{tabular}{|c} 
Weighted \\
Rating
\end{tabular} \\
\hline 6 & 3 & 18 \\
\hline $\begin{array}{c}\text { CTO } \\
\text { Weighting }\end{array}$ & $\begin{array}{c}\text { Raw } \\
\text { Rating }\end{array}$ & $\begin{array}{c}\text { Weighted } \\
\text { Rating }\end{array}$ \\
\hline & & \\
\hline
\end{tabular}

\begin{tabular}{|l|l|}
\hline 22 & 161 \\
\hline
\end{tabular}

\section{Comments}

\begin{tabular}{l} 
There does not appear to be any affect on forest resources. \\
\hline This technology can be applied to any boiler so the market could be fairly extensive. \\
\hline No real affect on energy performance. \\
\hline scheduled down time and provide more complete information on boiler tube status. \\
\hline There are two (2) groups assisting the technology team (Penn. State \& Weyco.) \\
\hline Existing technology being used for a new application. \\
\hline Not applicable. \\
\hline $\begin{array}{l}\text { This will be the only source of this type of technology for boiler tube checking. Patents are } \\
\text { being pursued. }\end{array}$ \\
\hline Not applicable. \\
\hline Low risk and good benefit. \\
\hline
\end{tabular}




\section{FOREST PRODUCTS INDUSTRY OF THE FUTURE - PORTFOLIO STUDY AND EVALUATION}

36-1491 Wireless Microwave Wood Moisture Measurement

\begin{tabular}{|c|c|c|c|c|c|c|c|}
\hline \multirow{2}{*}{1} & \multirow{2}{*}{$\begin{array}{l}\text { Sustained forest resource } \\
\text { management }\end{array}$} & \begin{tabular}{|c|} 
N/A or no \\
Significance
\end{tabular} & \begin{tabular}{|l|} 
Some \\
Significance \\
\end{tabular} & & \begin{tabular}{|c|} 
Moderate \\
Significance \\
\end{tabular} & & $\begin{array}{c}\text { High } \\
\text { Significance }\end{array}$ \\
\hline & & 0 & 1 & 2 & 3 & 4 & 5 \\
\hline \multirow[b]{2}{*}{2} & \multirow[b]{2}{*}{$\begin{array}{l}\text { Size and extent of market } \\
\text { for the new tectrology }\end{array}$} & \begin{tabular}{|l|} 
Very Smant \\
\end{tabular} & Small & & Medium & & Large \\
\hline & & 0 & 1 & 2 & 3 & 4 & 5 \\
\hline \multirow{3}{*}{3} & \multirow{3}{*}{ Energy perfomance } & no & ome & & \begin{tabular}{|l|l|} 
Moderate \\
\end{tabular} & & High \\
\hline & & Significance & | Significance & & Significance & & Significance \\
\hline & & 0 & 1 & 2 & 3 & 4 & 5 \\
\hline \multirow{2}{*}{4} & \multirow{2}{*}{ Economic atractiveness } & Unattractive & \begin{tabular}{|l|} 
Somenthat \\
Attractive
\end{tabular} & & Attractive & & $\begin{array}{l}\text { Highly } \\
\text { Atractive }\end{array}$ \\
\hline & & 0 & 1 & 2 & 3 & 4 & 5 \\
\hline \multirow{2}{*}{5} & \multirow{2}{*}{ Techrology champion } & None & \begin{tabular}{|l|} 
Assigned \\
Champion
\end{tabular} & & \begin{tabular}{|l|} 
Independent \\
Champion
\end{tabular} & & $\begin{array}{l}\text { Muttiple } \\
\text { Champions }\end{array}$ \\
\hline & & 0 & 1 & 2 & 3 & 4 & 5 \\
\hline \multirow{2}{*}{6} & \multirow{2}{*}{$\begin{array}{l}\text { Scientific insights derived } \\
\text { from project }\end{array}$} & \begin{tabular}{|l|} 
N/A or no \\
Significance \\
\end{tabular} & \begin{tabular}{|l|} 
Some \\
Significance
\end{tabular} & & \begin{tabular}{|c|} 
Moderale \\
Significance \\
\end{tabular} & & $\begin{array}{l}\text { High } \\
\text { Significance }\end{array}$ \\
\hline & & 0 & 1 & 2 & 3 & 4 & 5 \\
\hline \multirow{2}{*}{7} & \multirow{2}{*}{$\begin{array}{l}\text { Improved environmental } \\
\text { performance }\end{array}$} & \begin{tabular}{|c|} 
N/A or no \\
Significance
\end{tabular} & \begin{tabular}{|c|} 
Some \\
Significance
\end{tabular} & & \begin{tabular}{|c|} 
Moderate \\
Significance \\
\end{tabular} & & $\begin{array}{l}\text { High } \\
\text { Significance }\end{array}$ \\
\hline & & 0 & 1 & 2 & 3 & 4 & 5 \\
\hline \multirow{2}{*}{8} & \multirow{2}{*}{ Tectrological leadership } & \begin{tabular}{|c|} 
N/A or no \\
Significance
\end{tabular} & \begin{tabular}{|c|} 
Some \\
Significance
\end{tabular} & & \begin{tabular}{|c|} 
Moderate \\
Significance \\
\end{tabular} & & \begin{tabular}{|l} 
High \\
Significance
\end{tabular} \\
\hline & & 0 & 1 & 2 & 3 & 4 & 5 \\
\hline \multirow{2}{*}{9} & \multirow[b]{2}{*}{$\begin{array}{l}\text { Recycled wood and paper } \\
\text { materials }\end{array}$} & \begin{tabular}{|c|} 
N/A or no \\
Significance
\end{tabular} & $\begin{array}{l}\text { Some } \\
\text { Significance }\end{array}$ & & \begin{tabular}{|c|} 
Moderate \\
Significance \\
\end{tabular} & & $\begin{array}{l}\text { High } \\
\text { Significance }\end{array}$ \\
\hline & & 0 & 1 & 2 & 3 & 4 & 5 \\
\hline \multirow{2}{*}{10} & \multirow{2}{*}{ Risk } & High Risk & $\begin{array}{c}\text { Moderate } \\
\text { Risk }\end{array}$ & & Low Risk & & $\begin{array}{l}\text { Very Low } \\
\text { Risk }\end{array}$ \\
\hline & & 0 & 1 & 2 & 3 & 4 & 5 \\
\hline \multirow{2}{*}{11} & \multirow{2}{*}{ ses for biomass } & $\begin{array}{l}\text { N/A or no } \\
\text { Significance }\end{array}$ & $\begin{array}{l}\text { Some } \\
\text { Significance }\end{array}$ & & \begin{tabular}{|c|} 
Moderate \\
Significance
\end{tabular} & & $\begin{array}{c}\text { High } \\
\text { Significance } \\
\end{array}$ \\
\hline & & 0 & 1 & 2 & 3 & 4 & 5 \\
\hline
\end{tabular}

Totals

\section{Comments}

\begin{tabular}{|c|c|c|}
\hline $\begin{array}{c}\text { CTO } \\
\text { Weighting }\end{array}$ & $\begin{array}{c}\text { Raw } \\
\text { Rating }\end{array}$ & $\begin{array}{c}\text { Weighted } \\
\text { Rating }\end{array}$ \\
10 & 0 & 0 \\
\hline $\begin{array}{c}\text { CTO } \\
\text { Weighting }\end{array}$ & $\begin{array}{c}\text { Raw } \\
\text { Rating }\end{array}$ & $\begin{array}{c}\text { Weighted } \\
\text { Rating }\end{array}$ \\
9 & 4 & 36 \\
\hline $\begin{array}{c}\text { CTO } \\
\text { Weighting }\end{array}$ & $\begin{array}{c}\text { Raw } \\
\text { Rating }\end{array}$ & $\begin{array}{c}\text { Weighted } \\
\text { Rating }\end{array}$ \\
8 & 4 & 32 \\
\hline $\begin{array}{c}\text { CTO } \\
\text { Weighting }\end{array}$ & $\begin{array}{c}\text { Raw } \\
\text { Rating }\end{array}$ & $\begin{array}{c}\text { Weighted } \\
\text { Rating }\end{array}$ \\
8 & 4 & 32 \\
\hline $\begin{array}{c}\text { CTO } \\
\text { Weighting }\end{array}$ & $\begin{array}{c}\text { Raw } \\
\text { Rating }\end{array}$ & $\begin{array}{c}\text { Weighted } \\
\text { Rating }\end{array}$ \\
7 & 4 & 28 \\
\hline $\begin{array}{c}\text { CTO } \\
\text { Weighting }\end{array}$ & $\begin{array}{c}\text { Raw } \\
\text { Rating }\end{array}$ & $\begin{array}{c}\text { Weighted } \\
\text { Rating }\end{array}$ \\
7 & 3 & 21 \\
\hline $\begin{array}{c}\text { CTO } \\
\text { Weighting }\end{array}$ & $\begin{array}{c}\text { Raw } \\
\text { Rating }\end{array}$ & $\begin{array}{c}\text { Weighted } \\
\text { Rating }\end{array}$ \\
7 & 4 & 28 \\
\hline $\begin{array}{c}\text { CTO } \\
\text { Weighting }\end{array}$ & $\begin{array}{c}\text { Raw } \\
\text { Rating }\end{array}$ & $\begin{array}{c}\text { Weighted } \\
\text { Rating }\end{array}$ \\
7 & 3 & 21 \\
\hline $\begin{array}{c}\text { CTO } \\
\text { Weighting }\end{array}$ & $\begin{array}{c}\text { Raw } \\
\text { Rating }\end{array}$ & $\begin{array}{c}\text { Weighted } \\
\text { Rating }\end{array}$ \\
6 & 0 & 0 \\
\hline $\begin{array}{c}\text { CTO } \\
\text { Weighting }\end{array}$ & $\begin{array}{c}\text { Raw } \\
\text { Rating }\end{array}$ & $\begin{array}{c}\text { Weighted } \\
\text { Rating }\end{array}$ \\
6 & 4 & 24 \\
\hline $\begin{array}{c}\text { CTO } \\
\text { Weighting }\end{array}$ & $\begin{array}{c}\text { Raw } \\
\text { Rating }\end{array}$ & $\begin{array}{c}\text { Weighted } \\
\text { Rating }\end{array}$ \\
5 & 0 & 0 \\
\hline
\end{tabular}

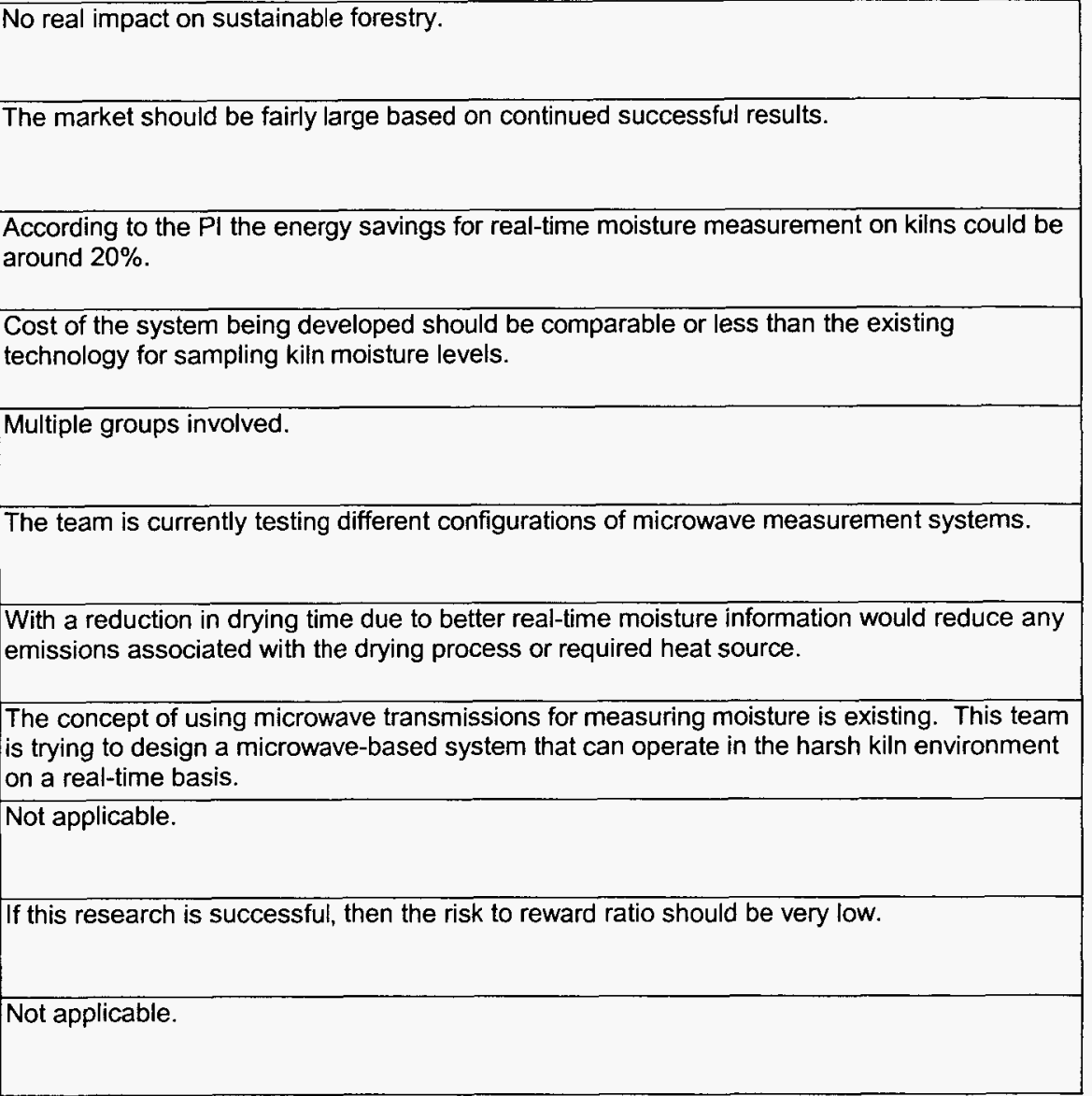




\begin{tabular}{|c|c|c|c|c|c|c|c|}
\hline 1 & $\begin{array}{l}\text { Sustained forest resource } \\
\text { management }\end{array}$ & $\begin{array}{c}\text { N/A or no } \\
\text { Significance } \\
0\end{array}$ & \begin{tabular}{|c|} 
Some \\
Significance \\
1
\end{tabular} & 2 & \begin{tabular}{|c|} 
Moderate \\
Significance \\
3 \\
\end{tabular} & 4 & \begin{tabular}{|c} 
High \\
Significance \\
5 \\
5
\end{tabular} \\
\hline 2 & $\begin{array}{l}\text { Size and extent of market } \\
\text { for the new technology }\end{array}$ & $\begin{array}{c}\text { Very Small } \\
0\end{array}$ & $\begin{array}{c}\text { Small } \\
1\end{array}$ & 2 & $\begin{array}{c}\text { Medium } \\
3\end{array}$ & 4 & $\begin{array}{l}\text { Large } \\
5 \\
5\end{array}$ \\
\hline 3 & Energy performance & \begin{tabular}{|c} 
N/A or no \\
Significance \\
0
\end{tabular} & \begin{tabular}{|c|} 
Some \\
Significance \\
1 \\
\end{tabular} & 2 & \begin{tabular}{|c|} 
Moderate \\
Significance \\
3 \\
\end{tabular} & 4 & $\begin{array}{c}\text { High } \\
\text { Significance } \\
5 \\
5\end{array}$ \\
\hline 4 & Economic attractiveness & $\begin{array}{c}\text { Unattractive } \\
0\end{array}$ & \begin{tabular}{|c|}
$\begin{array}{c}\text { Somewhat } \\
\text { Atractive } \\
1 \\
1\end{array}$ \\
\end{tabular} & 2 & \begin{tabular}{|c|} 
Atractive \\
3 \\
\end{tabular} & 4 & $\begin{array}{c}\text { Highly } \\
\text { Attractive } \\
5 \\
5\end{array}$ \\
\hline 5 & Technology champion & $\begin{array}{c}\text { None } \\
0 \\
0\end{array}$ & \begin{tabular}{|c|} 
Assigned \\
Champion \\
1
\end{tabular} & 2 & $\begin{array}{c}\text { independent } \\
\text { Cnampion } \\
\mathbf{3}\end{array}$ & 4 & \begin{tabular}{|c|} 
Mutitiple \\
Champions \\
5 \\
5
\end{tabular} \\
\hline 6 & $\begin{array}{l}\text { Scientific insights derived } \\
\text { from project }\end{array}$ & $\begin{array}{c}\text { N/A or no } \\
\text { Significance } \\
0\end{array}$ & \begin{tabular}{|c|} 
Some \\
Significance \\
1 \\
\end{tabular} & 2 & $\begin{array}{c}\text { Moderate } \\
\text { Significance } \\
3\end{array}$ & 4 & $\begin{array}{c}\text { High } \\
\text { Significance } \\
5 \\
5\end{array}$ \\
\hline 7 & $\begin{array}{l}\text { Improved environmental } \\
\text { performance }\end{array}$ & $\begin{array}{c}\text { N/A or no } \\
\text { Significance } \\
0\end{array}$ & \begin{tabular}{|c|} 
Some \\
Significance \\
1
\end{tabular} & 2 & \begin{tabular}{|c|} 
Moderate \\
Significance \\
3 \\
\end{tabular} & 4 & \begin{tabular}{|c} 
High \\
Significance \\
5
\end{tabular} \\
\hline 8 & Technological leadership & $\begin{array}{c}\text { N/A or no } \\
\text { Significance } \\
0\end{array}$ & \begin{tabular}{|c|} 
Some \\
Significance \\
1
\end{tabular} & 2 & \begin{tabular}{|c|} 
Moderate \\
Signnificannee \\
3 \\
\end{tabular} & 4 & $\begin{array}{c}\text { High } \\
\text { Significance } \\
5\end{array}$ \\
\hline 9 & $\begin{array}{l}\text { Recycled wood and paper } \\
\text { materials }\end{array}$ & $\begin{array}{c}\text { N/A or no } \\
\text { Significance } \\
0\end{array}$ & \begin{tabular}{|c|} 
Some \\
Significance \\
1
\end{tabular} & 2 & $\begin{array}{c}\text { Moderate } \\
\text { Stgnificance } \\
3 \\
\end{array}$ & 4 & $\begin{array}{c}\text { High } \\
\text { Significance } \\
5\end{array}$ \\
\hline 10 & Risk & $\begin{array}{c}\text { High Risk } \\
0\end{array}$ & \begin{tabular}{|c|} 
Moderate \\
Risk \\
1
\end{tabular} & 2 & $\begin{array}{c}\text { Low Risk } \\
3\end{array}$ & 4 & $\begin{array}{c}\text { Very Low } \\
\text { Risk } \\
5\end{array}$ \\
\hline 11 & Altemate uses for biomass & $\begin{array}{c}\text { N/A or o } \\
\text { Significance } \\
0\end{array}$ & \begin{tabular}{|c|} 
Some \\
Significance \\
1
\end{tabular} & 2 & \begin{tabular}{|c|} 
Moderate \\
Significance \\
3 \\
\end{tabular} & 4 & \begin{tabular}{|c|} 
High \\
Significance \\
5
\end{tabular} \\
\hline
\end{tabular}

Totals

\begin{tabular}{|c|c|c|}
\hline $\begin{array}{c}\text { CTO } \\
\text { Weighting }\end{array}$ & $\begin{array}{l}\text { Raw } \\
\text { Rating }\end{array}$ & $\begin{array}{c}\text { Weighted } \\
\text { Rating }\end{array}$ \\
\hline 10 & 0 & 0 \\
\hline $\begin{array}{c}\text { CTO } \\
\text { Weighting }\end{array}$ & $\begin{array}{l}\text { Raw } \\
\text { Rating }\end{array}$ & $\begin{array}{c}\text { Weighted } \\
\text { Rating }\end{array}$ \\
\hline 9 & 3 & 27 \\
\hline $\begin{array}{c}\text { CTO } \\
\text { Weighting }\end{array}$ & $\begin{array}{l}\text { Raw } \\
\text { Rating }\end{array}$ & $\begin{array}{c}\text { Weighted } \\
\text { Rating }\end{array}$ \\
\hline 8 & 4 & 32 \\
\hline $\begin{array}{c}\text { CTO } \\
\text { weighting }\end{array}$ & $\begin{array}{l}\text { Raw } \\
\text { Rating }\end{array}$ & $\begin{array}{c}\text { Weighted } \\
\text { Rating }\end{array}$ \\
\hline 8 & 3 & 24 \\
\hline $\begin{array}{c}\text { CTO } \\
\text { Weighting }\end{array}$ & $\begin{array}{l}\text { Raw } \\
\text { Rating }\end{array}$ & $\begin{array}{c}\text { Weighted } \\
\text { Rating }\end{array}$ \\
\hline 7 & 3 & 21 \\
\hline $\begin{array}{c}\text { CTO } \\
\text { Weighting }\end{array}$ & $\begin{array}{l}\text { Raw } \\
\text { Rating }\end{array}$ & $\begin{array}{c}\text { Weighted } \\
\text { Rating }\end{array}$ \\
\hline 7 & 3 & 21 \\
\hline $\begin{array}{c}\text { CTO } \\
\text { Weighting }\end{array}$ & $\begin{array}{l}\text { Raw } \\
\text { Rating }\end{array}$ & $\begin{array}{c}\text { Weighted } \\
\text { Rating }\end{array}$ \\
\hline 7 & 4 & 28 \\
\hline $\begin{array}{c}\text { CTO } \\
\text { Weighting }\end{array}$ & $\begin{array}{l}\text { Raw } \\
\text { Rating }\end{array}$ & $\begin{array}{c}\text { Weighted } \\
\text { Rating }\end{array}$ \\
\hline 7 & 4 & 28 \\
\hline $\begin{array}{c}\text { CTO } \\
\text { Weighting }\end{array}$ & $\begin{array}{l}\text { Raw } \\
\text { Rating }\end{array}$ & $\begin{array}{c}\text { Weighted } \\
\text { Rafing }\end{array}$ \\
\hline 6 & 1 & 6 \\
\hline $\begin{array}{c}\text { CTO } \\
\text { Weighting }\end{array}$ & $\begin{array}{l}\text { Raw } \\
\text { Rating }\end{array}$ & $\begin{array}{c}\text { Weighted } \\
\text { Rating }\end{array}$ \\
\hline 6 & 3 & 18 \\
\hline $\begin{array}{c}\text { CTO } \\
\text { Weighting }\end{array}$ & $\begin{array}{l}\text { Raw } \\
\text { Rating }\end{array}$ & $\begin{array}{c}\text { Weighted } \\
\text { Rating }\end{array}$ \\
\hline 5 & 1 & 5 \\
\hline
\end{tabular}

29

\begin{tabular}{|l|}
\hline There does not appear to be any affect on forest resources. \\
\hline $\begin{array}{l}\text { All paper mills would benefit from the successful results of this project through more efficient } \\
\text { processing of black liquor. }\end{array}$ \\
\hline $\begin{array}{l}\text { Better atomization and control of the black liquor nozzle spray would increase the energy } \\
\text { (thermal) production of the chemical recovery boiler. }\end{array}$ \\
\hline Increasing the efficiency of processing black liquor in chemical recovery boilers would in turn \\
save money in this process. \\
\hline McDermott Technologies Inc. has been the research team's main support for this project. \\
\hline There will be concepts learned in developing a CFD model for black liquor nozzles. \\
\hline Improved nozzle performance means better combustion and fewer emissions. \\
\hline Since there are no current models for black liquor nozzles this will be the first and only. \\
\hline Not applicable. \\
\hline Low risk and good benefit. \\
\hline
\end{tabular}


FOREST PRODUCTS INDUSTRY OF THE FUTURE

PORTFOLIO STUDY AND EVALUATION

Appendix F

Agenda 2020 Implementation Plan R\&D Pathways 
FOREST PRODUCTS INDUSTRY OF THE FUTURE - PORTFOLIO STUDY AND EVALUATION

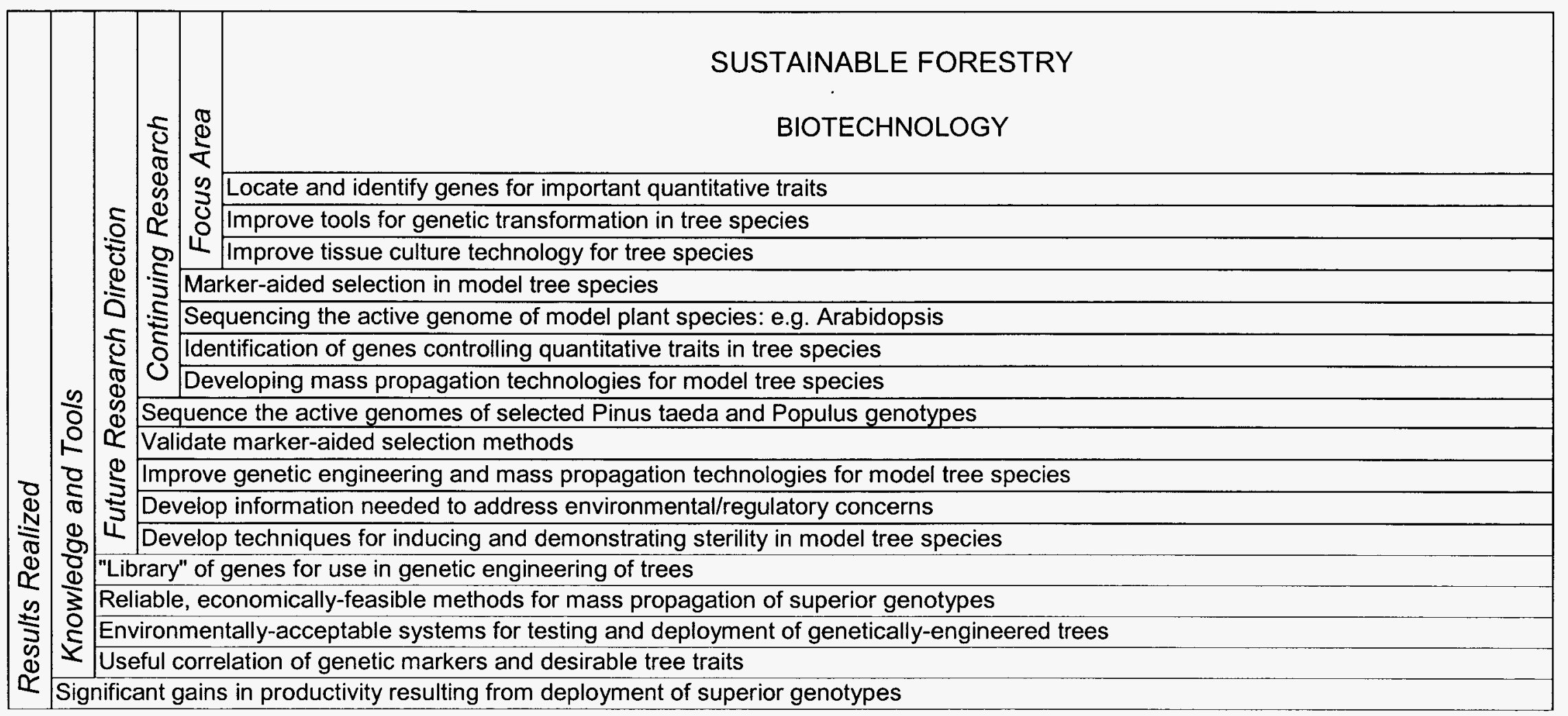




\begin{tabular}{|l|l|l|l|l|}
\hline & & & \\
\end{tabular}




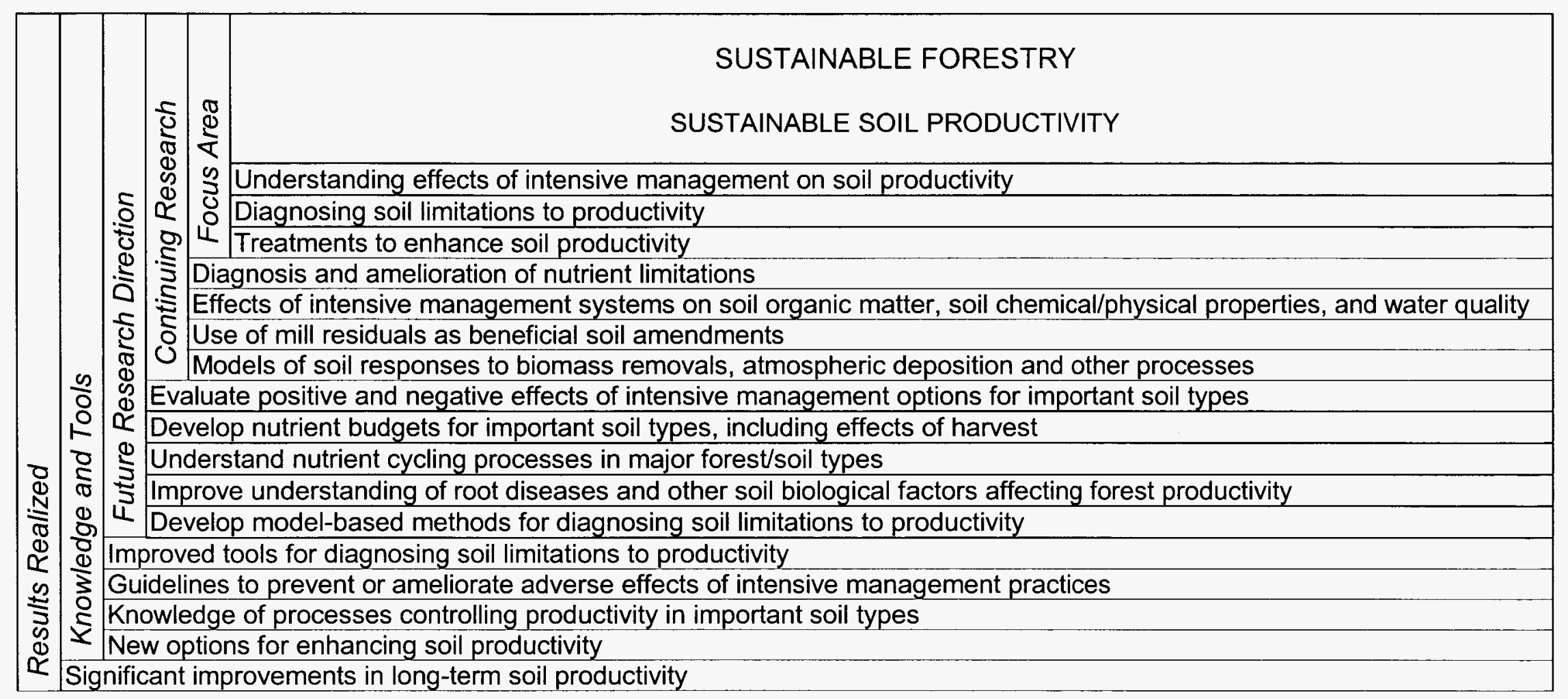




\begin{tabular}{|l|l|l|l|l|l|}
\hline & & & & \\
& & & & \\
\end{tabular}


FOREST PRODUCTS INDUSTRY OF THE FUTURE - PORTFOLIO STUDY AND EVALUATION

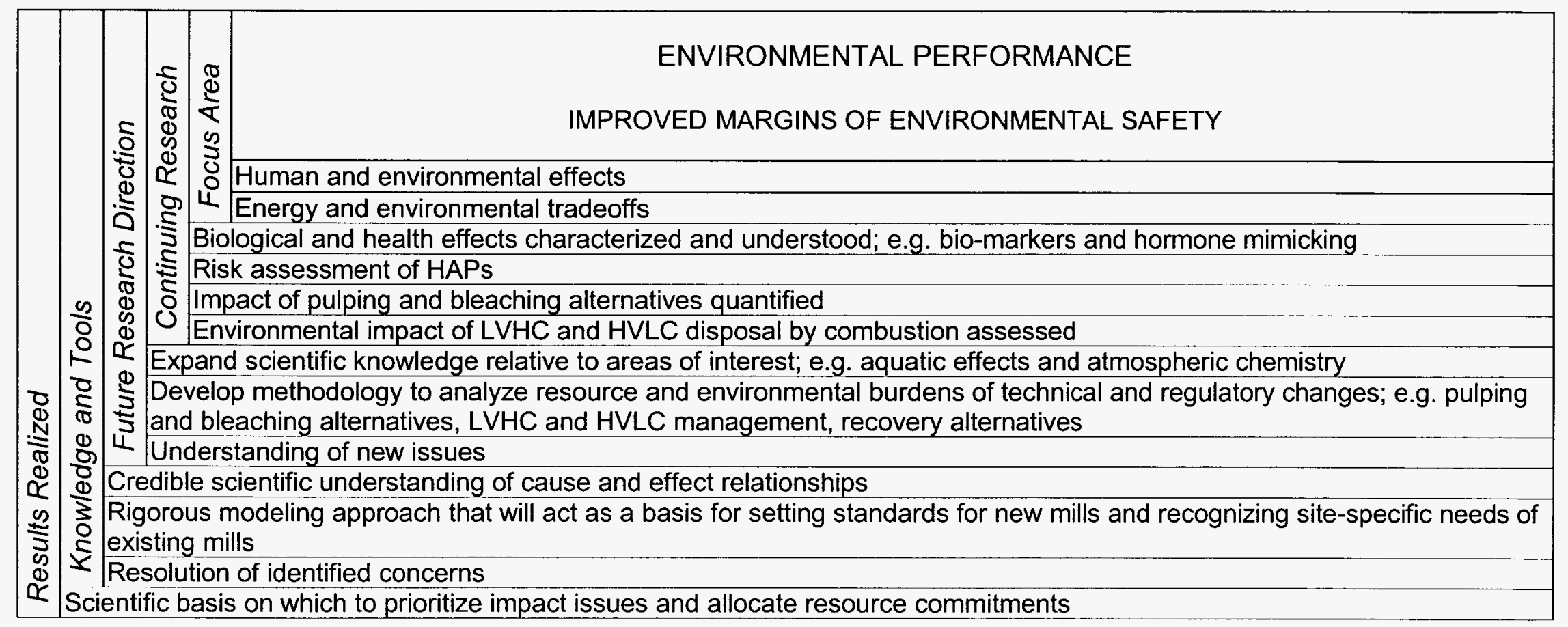




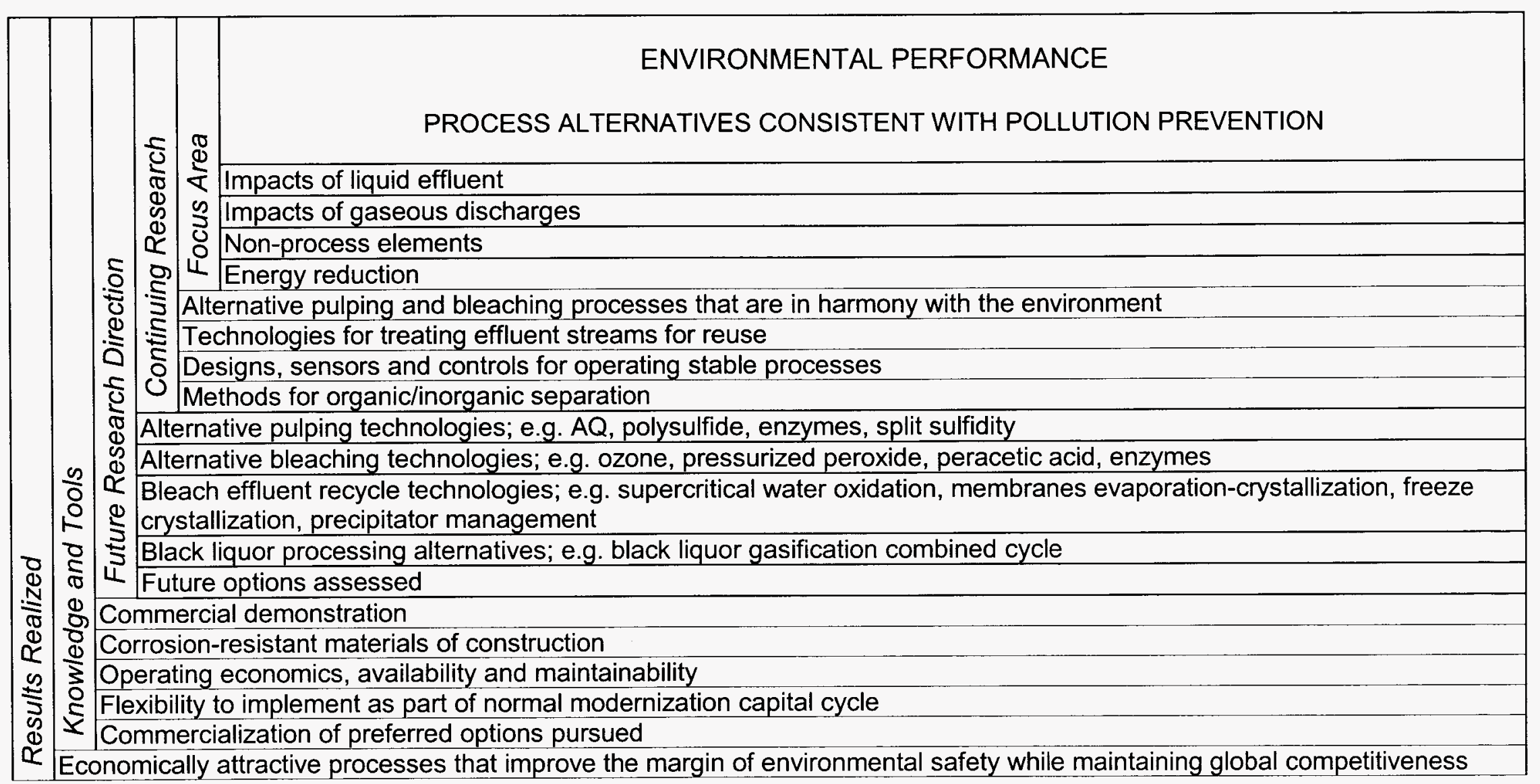


FOREST PRODUCTS INDUSTRY OF THE FUTURE - PORTFOLIO STUDY AND EVALUATION

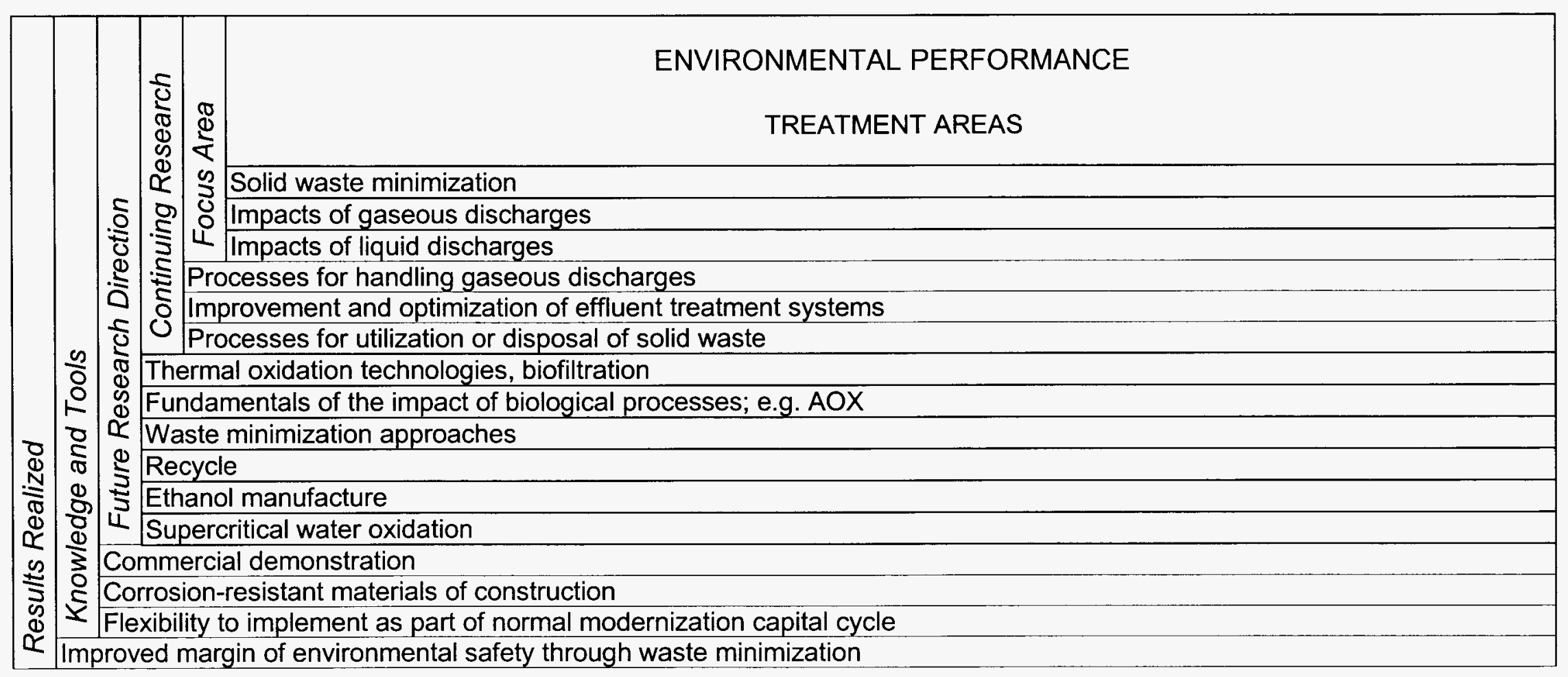


FOREST PRODUCTS INDUSTRY OF THE FUTURE - PORTFOLIO STUDY AND EVALUATION

\begin{tabular}{|c|c|c|c|c|c|}
\hline \multirow{12}{*}{ 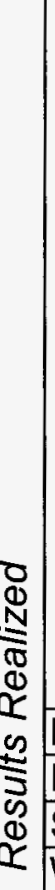 } & & \multirow{8}{*}{ 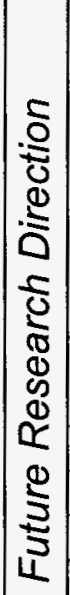 } & \multirow{3}{*}{ } & $\mid \begin{array}{c}0 \\
\mathbb{d} \\
\frac{1}{2} \\
y \\
3 \\
0 \\
0\end{array}$ & $\begin{array}{c}\text { ENERGY PERFORMANCE } \\
\text { FUEL PRODUCTION AND ENHANCEMENT }\end{array}$ \\
\hline & & & & \begin{tabular}{|l|l}
1 \\
Agri
\end{tabular} & $\begin{array}{l}\text { Technologies for maximizing the value of waste materials and biomass as an energy source } \\
\text { icultural residues as fuel and as feedstock for chemicals }\end{array}$ \\
\hline & & & & Non & -recyclable recoverable materials as a fuel \\
\hline & $\frac{1}{2}$ & & & & $\begin{array}{l}\text { and plantation management strategies and prescriptions that will optimize "energy fiber" generation while } \\
\text { ing overall productivity }\end{array}$ \\
\hline & ఉా & & Coll & lectic & on and harvesting systems and techniques to increase forest residual availability and reduce costs \\
\hline & के & & Imp & orove & ed moisture reduction techniques, including drying \\
\hline & ర్ల & & Tec & chnol & logies for beneficiation of wastes and other recyclable materials \\
\hline & $\frac{\pi}{3}$ & & $\operatorname{Imp}$ & orove & ed materials handling technologies \\
\hline & & & $\frac{w \text { int }}{\text { stem }}$ & tegra & $\begin{array}{l}\text { ated systems for growing, harvesting, sorting, and developing energy fiber from forests and plantations } \\
\text { r collecting sorting and beneficiatina nonrecvclable recovered material for enerav }\end{array}$ \\
\hline & $\mathrm{Ma}$ & axim & um I & value & e of forest resources \\
\hline & & exibil & lity to & o util & lize the cheapest fuels \\
\hline & & & & 5 & ssil fuel price perturbations and ener \\
\hline
\end{tabular}




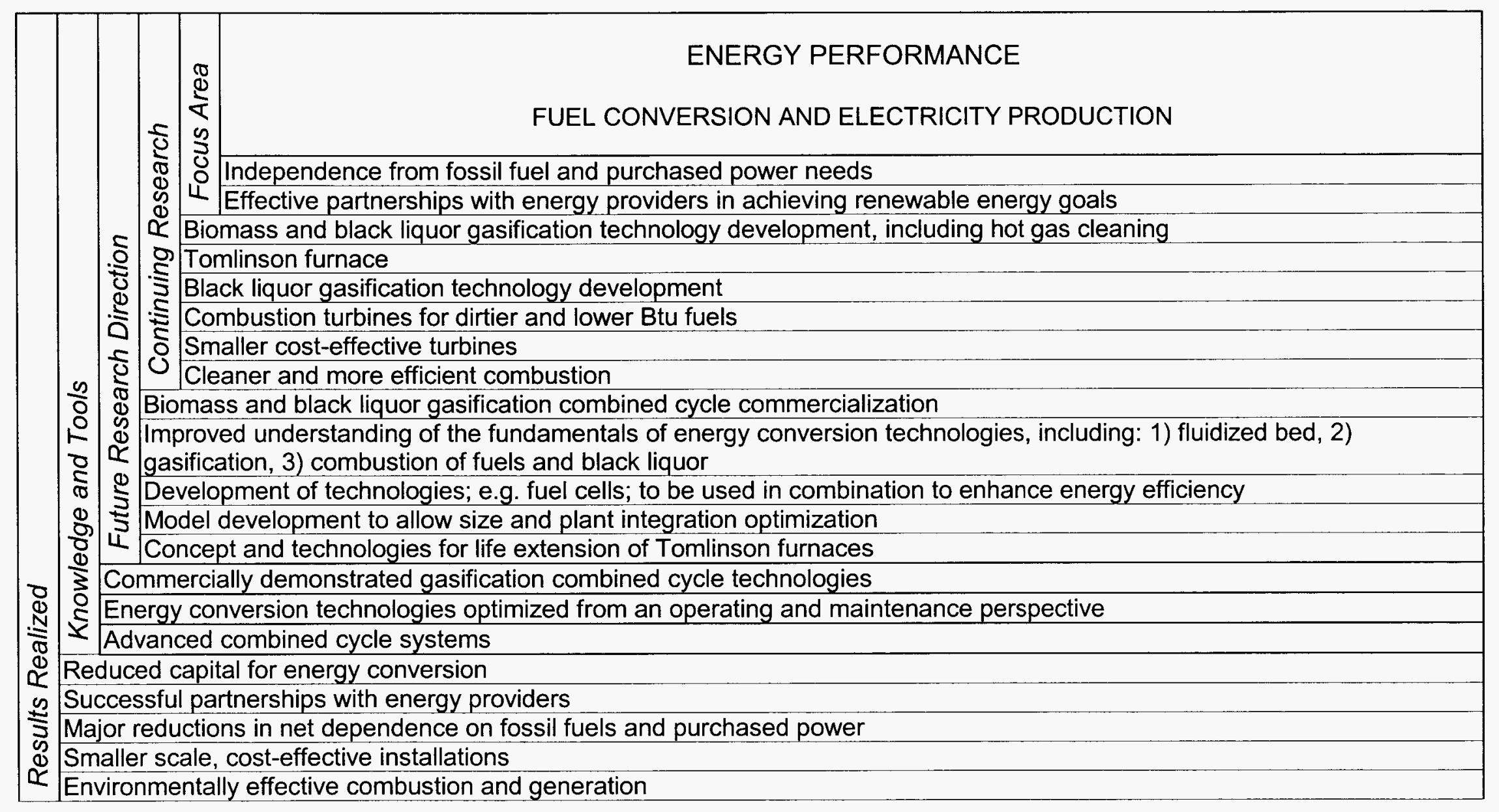




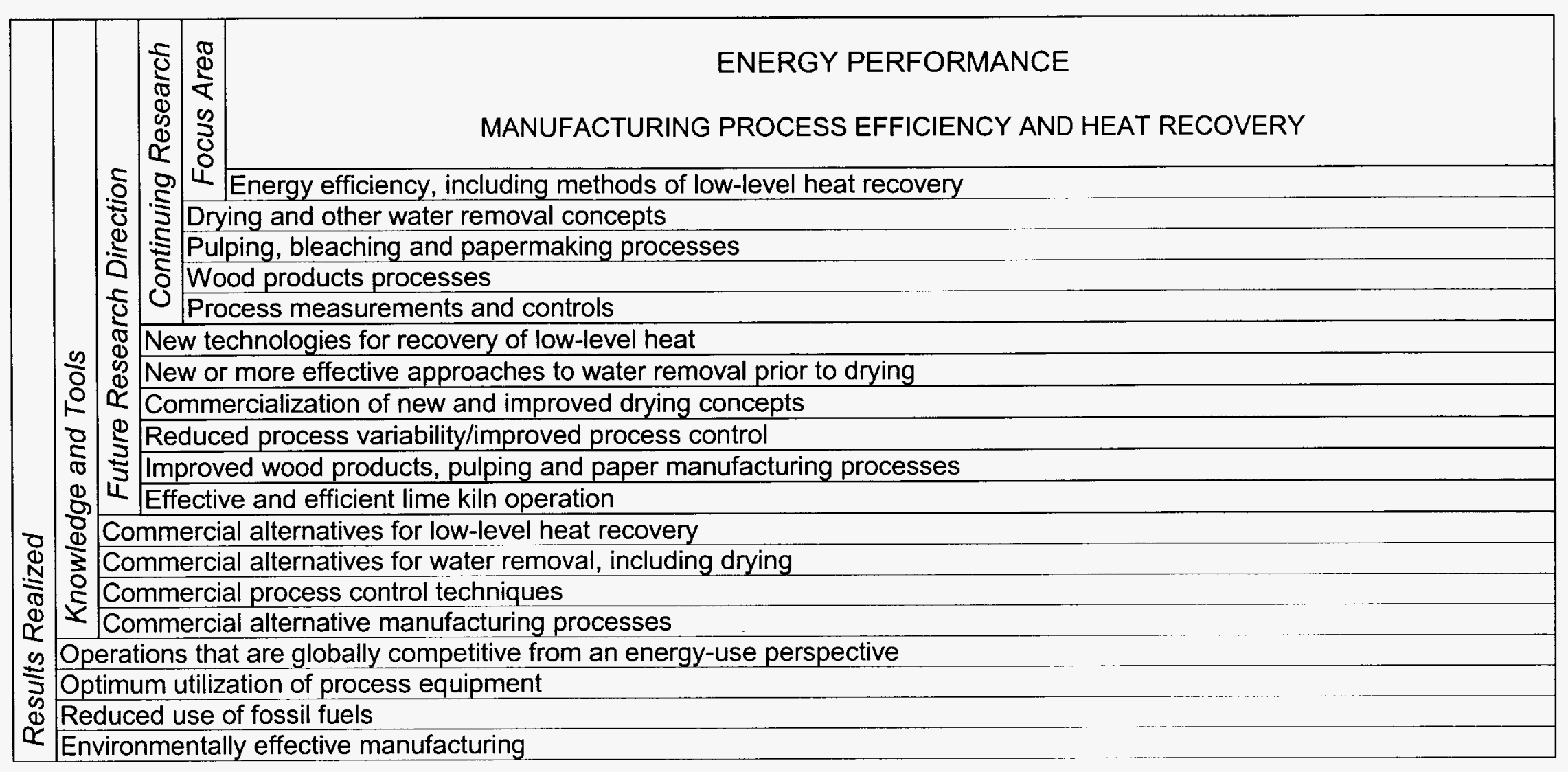


FOREST PRODUCTS INDUSTRY OF THE FUTURE - PORTFOLIO STUDY AND EVALUATION

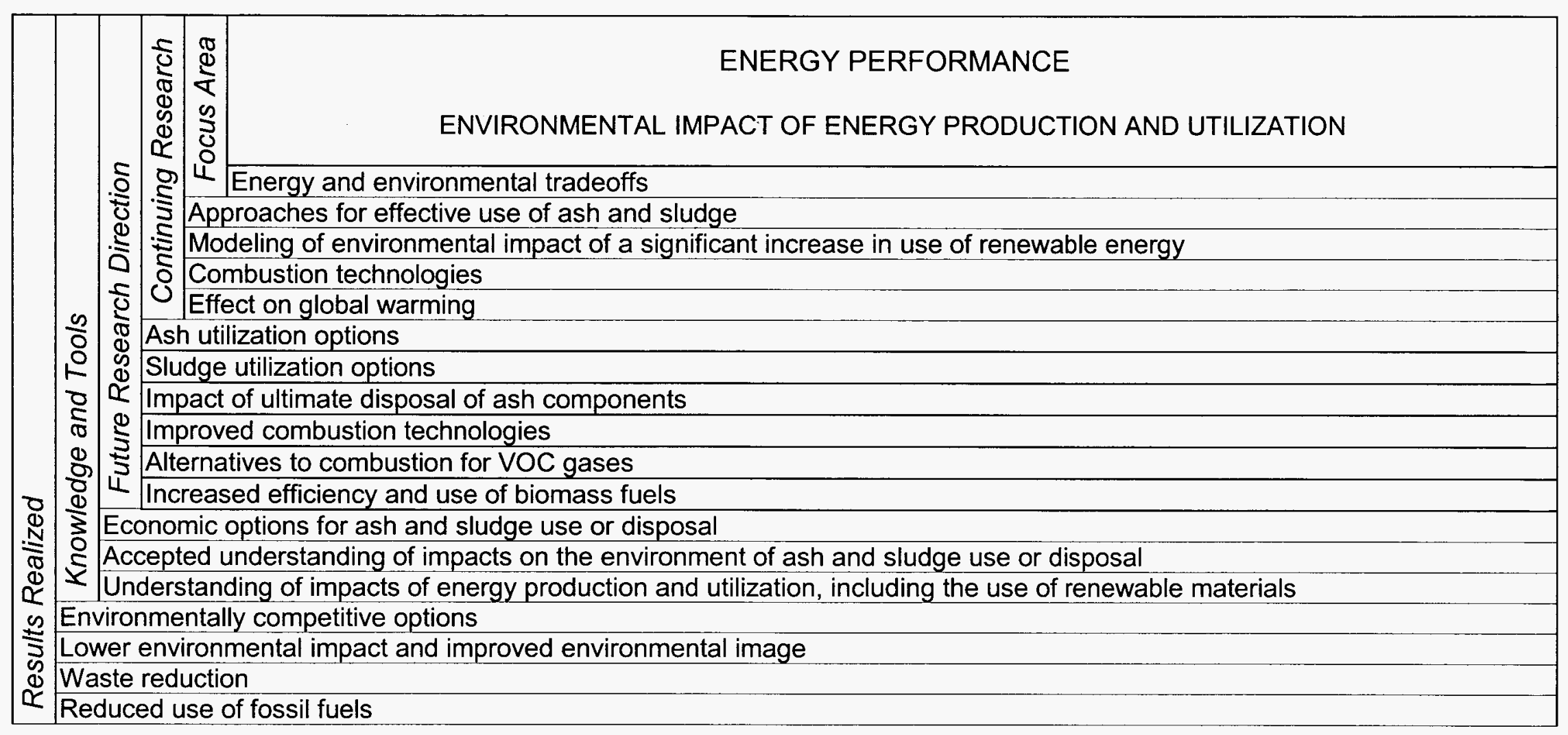


FOREST PRODUCTS INDUSTRY OF THE FUTURE - PORTFOLIO STUDY AND EVALUATION

\begin{tabular}{|c|c|c|c|c|c|}
\hline \multirow{12}{*}{\multicolumn{2}{|c|}{ 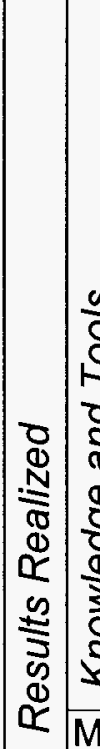 }} & \multirow{10}{*}{\multicolumn{2}{|c|}{ 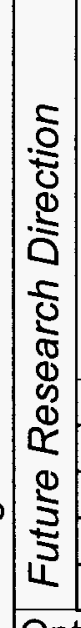 }} & 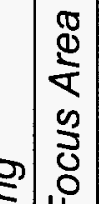 & $\begin{array}{c}\text { ENERGY PERFORMANCE } \\
\text { WIDER USE OF RENEWABLE RESOURCES }\end{array}$ \\
\hline & & & & & Technologies for maximizing the value of waste materials and biomass as an energy source \\
\hline & & & & & mass-to-chemical conversion processes \\
\hline & & & & & chnologies for recycling wood \\
\hline & & & & Life & extension of wood products \\
\hline & & & $8 \quad$ Co & omme & ercialization of improved biomass-to-chemicals conversion technologies \\
\hline & & & $\operatorname{Pr}$ & roces: & s integration alternatives allowing for attractive chemical production opportunities \\
\hline & & & $\operatorname{lm}$ & nprove & ed technologies for wood products recycling \\
\hline & & & Un & nders & tanding of the energy efficiency in production and use of forest and paper products relative to competing products \\
\hline & & & & reater & r life of wood buildings via design and repair \\
\hline & & & ption & ns for & effective partnerships with utilities, chemical and oil companies, designers and repair entities \\
\hline & & & & & of forest resources \\
\hline
\end{tabular}




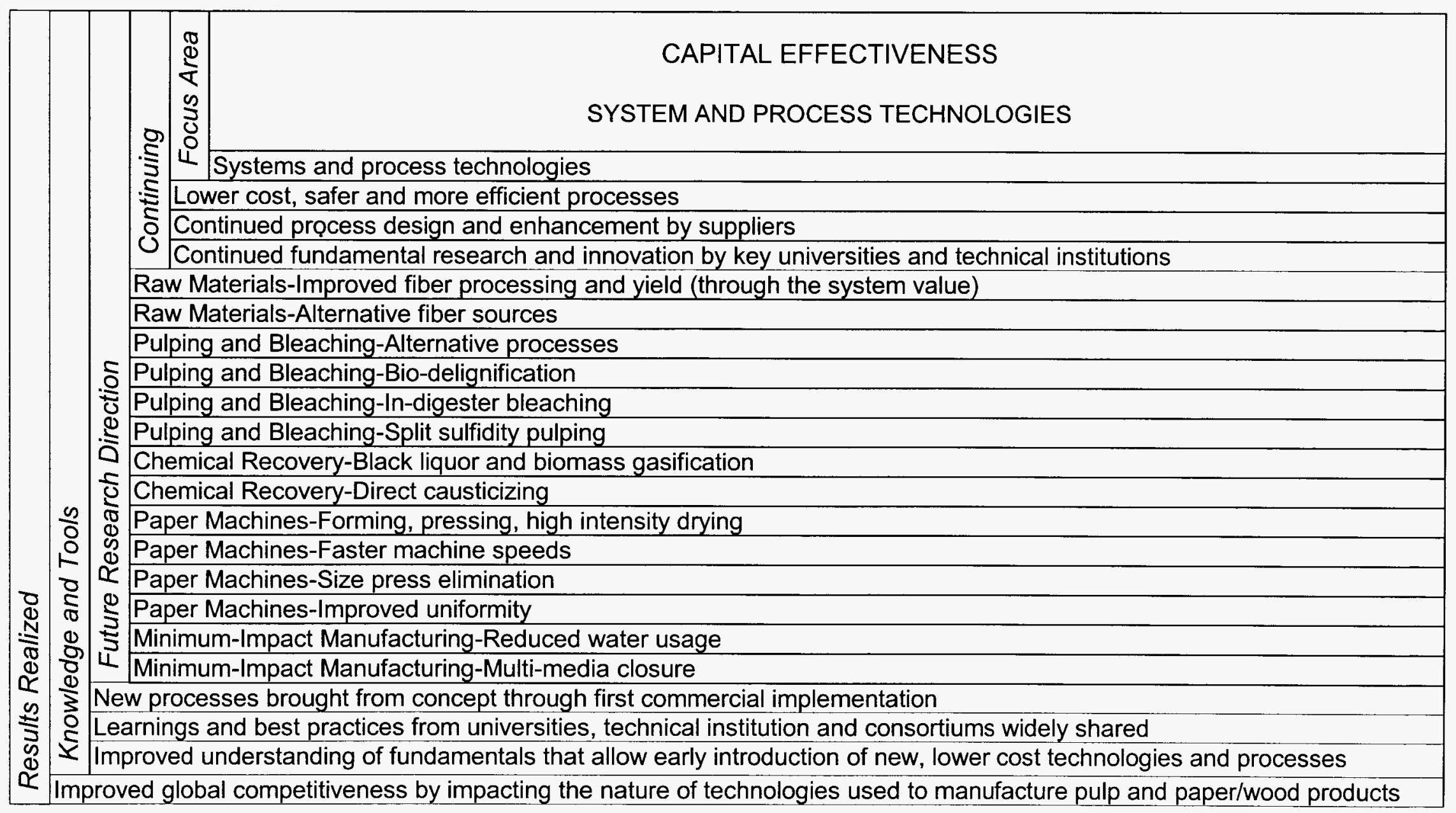




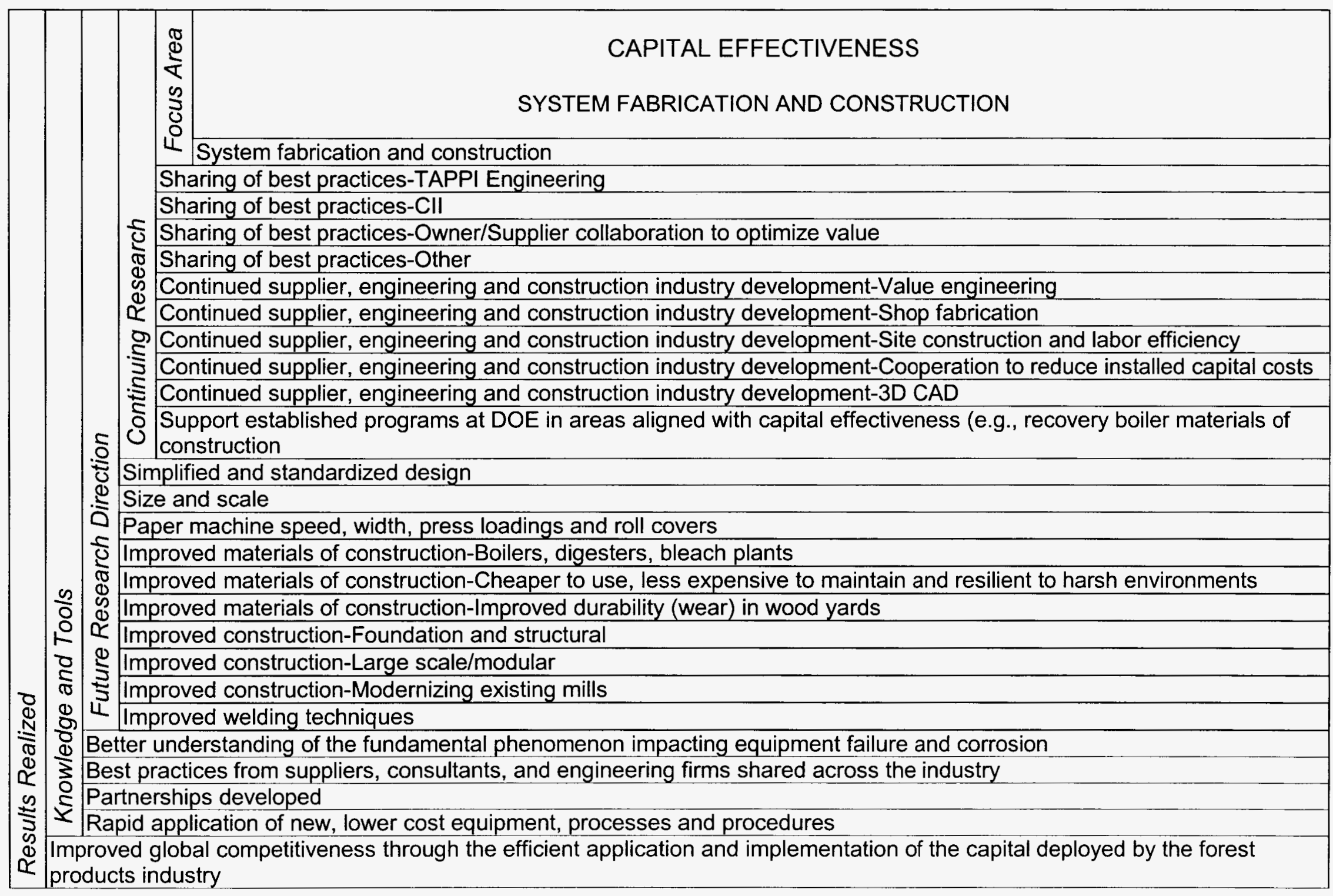


FOREST PRODUCTS INDUSTRY OF THE FUTURE - PORTFOLIO STUDY AND EVALUATION

\begin{tabular}{|c|c|c|c|c|c|}
\hline & & & & 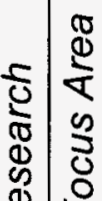 & $\begin{array}{c}\text { CAPITAL EFFECTIVENESS } \\
\text { SYSTEM EFFICIENCY }\end{array}$ \\
\hline & & & & LL & System efficiency \\
\hline & & & & ge & veloping skilled resources for the industry-Maintenance and operations \\
\hline & & & 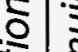 & De & veloping skilled resources for the industry-Discipline engineers \\
\hline & & & $\stackrel{5}{1}$ & $\equiv \overline{D e}$ & veloping skilled resources for the industry-Process engineers \\
\hline & & & ¿ & Co & ontinued development of process monitoring tools for the industry by suppliers \\
\hline & & & $\underline{a}$ & $0 \longdiv { \mathrm { Co } _ { 0 } }$ & ontinued development of fundamental process knowledge by key technical institutions and suppliers \\
\hline & & & 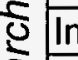 & Improv & ved modeling, simulation, optimization and operator training tools \\
\hline & $\frac{c}{c}$ & $\frac{n}{0}$ & $\mathbb{D}$ & Diagne & ostic and smart sensors to reduce unscheduled downtime \\
\hline & r & $\begin{array}{lll}0 & 0 \\
0 & 0 & 0\end{array}$ & $\bar{d} \ln$ & Intellig & ent maintenance-Proactive \\
\hline & & 8 & Ir & Intellig & ent maintenance-Allow to design process and systems on the edge \\
\hline$\stackrel{n}{d}$ & 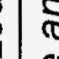 & $\sqrt{6}$ & 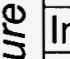 & Intellig & ent maintenance-Maintain facilities "on the run" \\
\hline 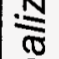 & & 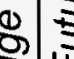 & $\stackrel{R}{R}$ & Reduc & ed raw materials variability \\
\hline$\underset{0}{0}$ & 2 & ¿ & $\perp \bar{C}$ & Chemi & ical and energy optimization \\
\hline w & & $A$ & div & verse & set of skilled resources capable of meeting the challenges of the future \\
\hline$\sum_{S}^{5}$ & & $\stackrel{\ln }{S}$ & mprc & roved & process models and tools for optimization \\
\hline$\Phi$ & 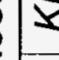 & & & roved & economics, availability and maintainability of core manufacturing processes \\
\hline $\mathbb{1}$ & & & & d & jal competitiveness through better manufacturing asset utilization \\
\hline
\end{tabular}




\begin{tabular}{|l|l|l|l|l|}
\hline & & & & \\
\end{tabular}




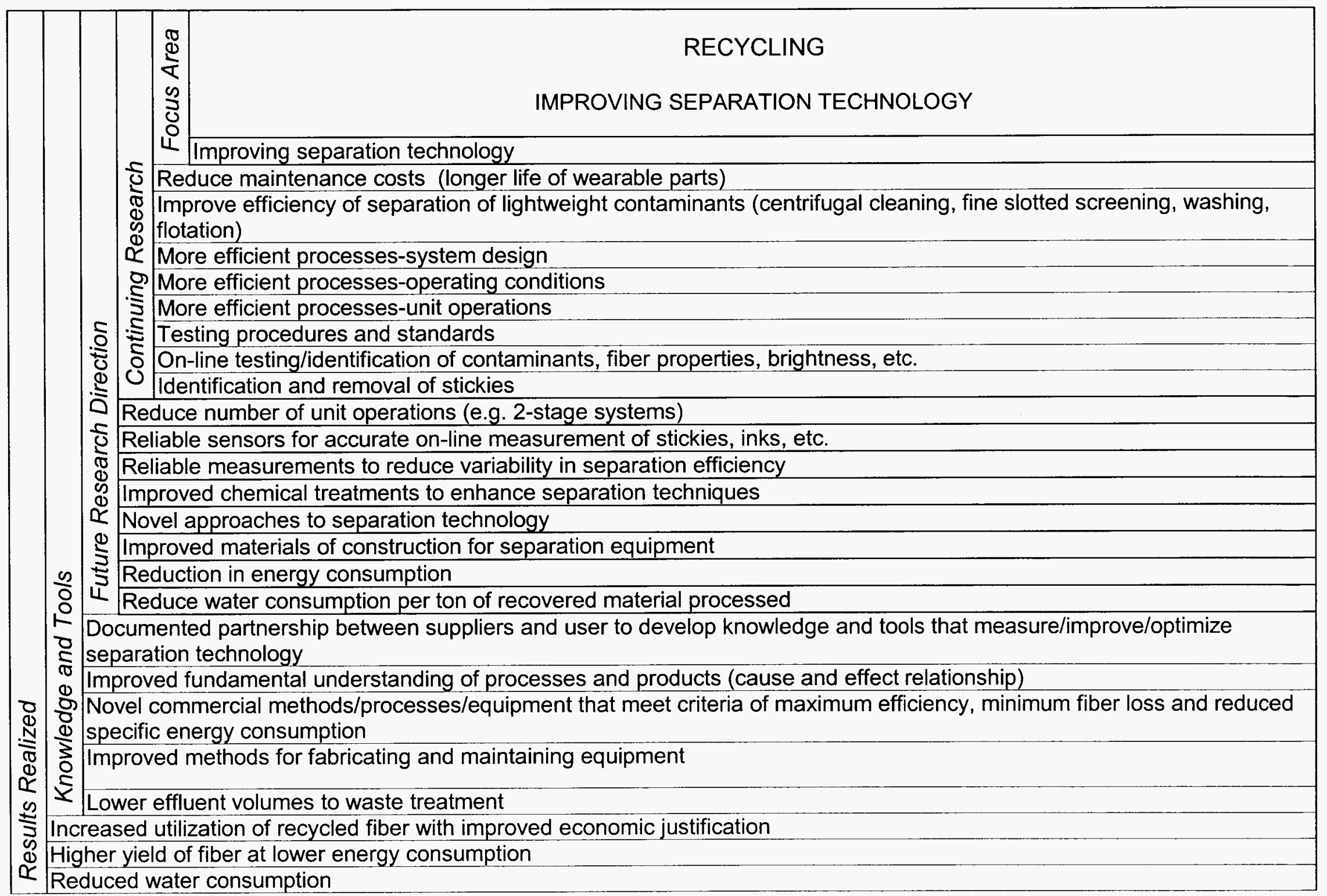


FOREST PRODUCTS INDUSTRY OF THE FUTURE - PORTFOLIO STUDY AND EVALUATION

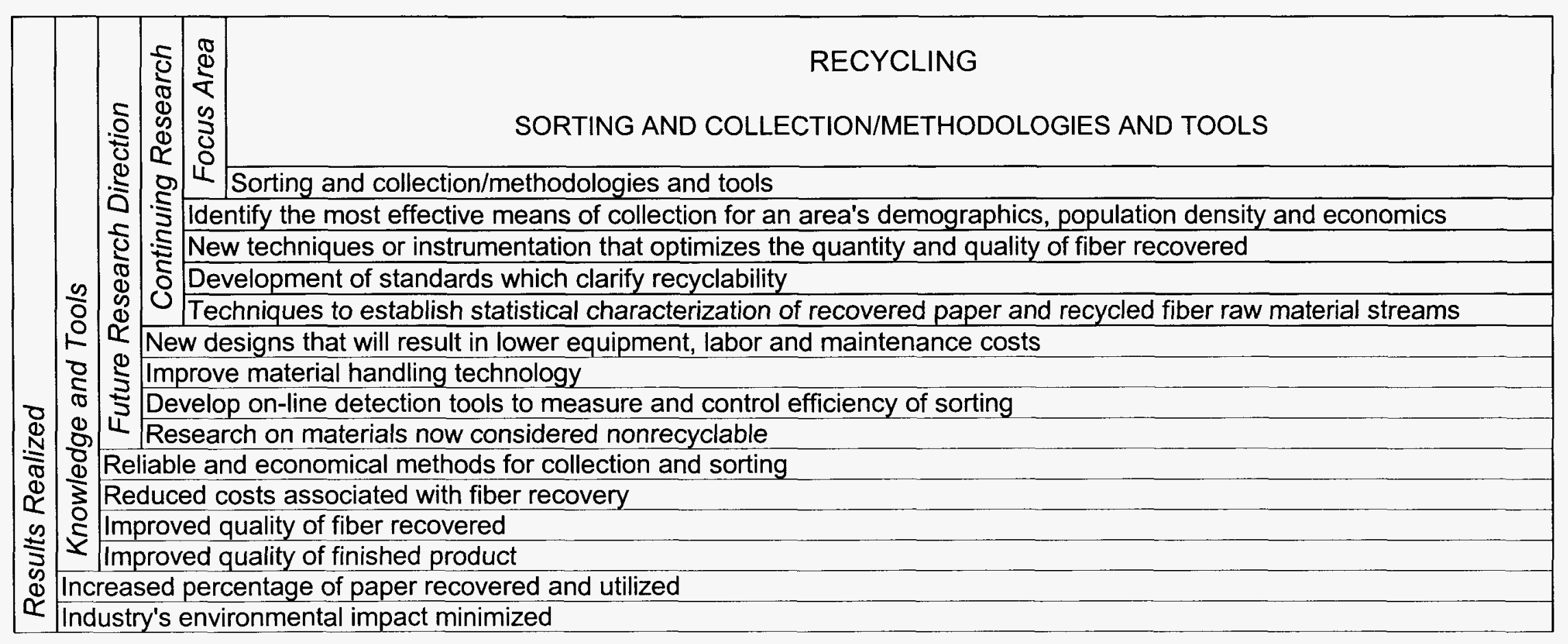




\section{FOREST PRODUCTS INDUSTRY OF THE FUTURE - PORTFOLIO STUDY AND EVALUATION}

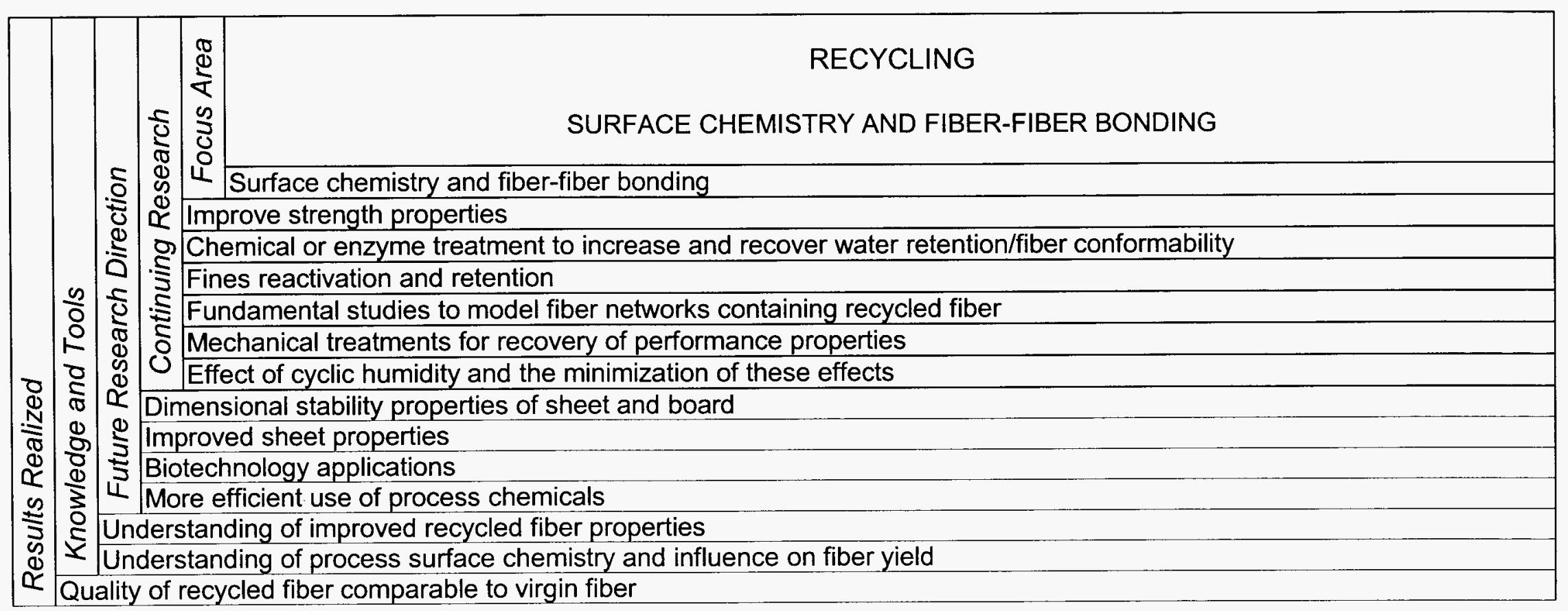




\section{FOREST PRODUCTS INDUSTRY OF THE FUTURE - PORTFOLIO STUDY AND EVALUATION}

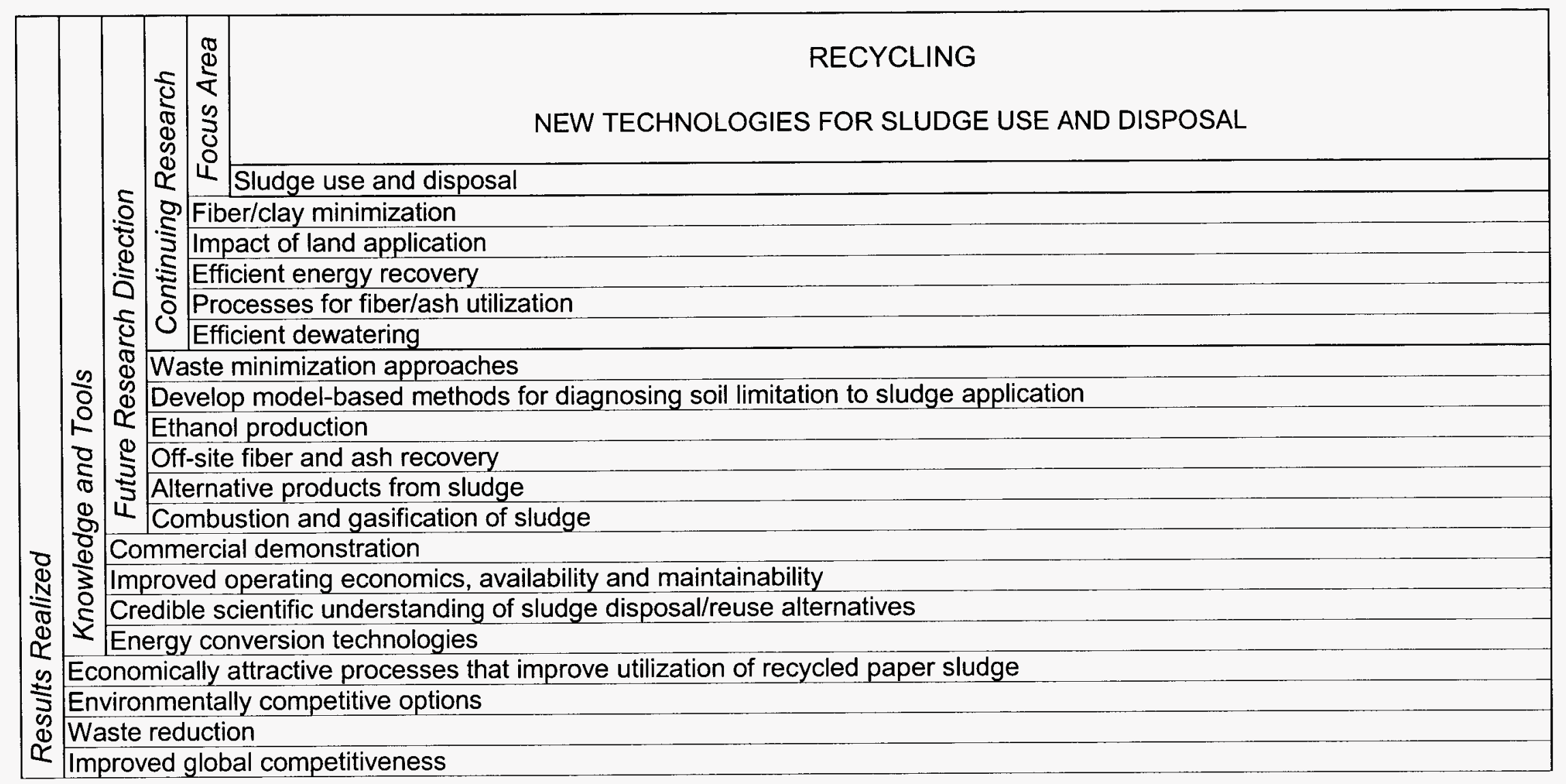


FOREST PRODUCTS INDUSTRY OF THE FUTURE - PORTFOLIO STUDY AND EVALUATION

\begin{tabular}{|c|c|c|c|c|c|}
\hline & & & 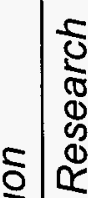 & 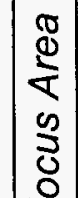 & $\begin{array}{c}\text { SENSORS AND CONTROLS } \\
\text { ACTUATORS AND CONTROL DEVICES }\end{array}$ \\
\hline & & & 8 & & Surface chemistry and fiber-fiber bonding \\
\hline & & 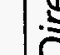 & $\stackrel{0}{3}$ & Mic & croprocessors at actuator level \\
\hline & & & 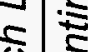 & $\operatorname{Imp}$ & proved flow control \\
\hline & & & 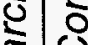 & $\mathrm{He}$ & ad box dilution control \\
\hline & & 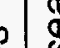 & 0 & Act & tuators to stabilize processes \\
\hline & $\bar{c}$ & & 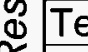 & chni & iques/methods to minimize/eliminate variability \\
\hline & F & & $A C$ & ttuatc & ors that keep up with control system development \\
\hline & 8 & & $\stackrel{\mathrm{AC}}{\Xi}$ & tuat & ors that satisfy product requirements \\
\hline & $\pi$ & & 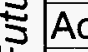 & tuat & ors for new processes \\
\hline & $\frac{1}{8}$ & & $\perp \mathrm{Se}$ & elf-di & agnostic \\
\hline & 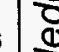 & & Actua & tors & for critical product variables \\
\hline$\stackrel{D}{N}$ & $\overline{3}$ & & Actua & tors & for critical process variables \\
\hline$=0$ & $\int_{2}^{2}$ & & Actua & tors & for raw material variables \\
\hline $\mid \begin{array}{l}0 \\
\mathbb{1}\end{array}$ & $x$ & & Actua & tors & for environmental variables \\
\hline$\stackrel{0}{5}$ & & & $\begin{array}{l}\text { able a } \\
\text { omer }\end{array}$ & and 0 & $\begin{array}{l}\text { Cost-effective actuators enabling optimal process operation, environmental performance, safe performance and } \\
\text { sfaction }\end{array}$ \\
\hline $\begin{array}{c}\mathscr{D} \\
\mathbb{1} \\
\mathbb{1}\end{array}$ & & & ductiv & & \\
\hline & & & & & \\
\hline
\end{tabular}




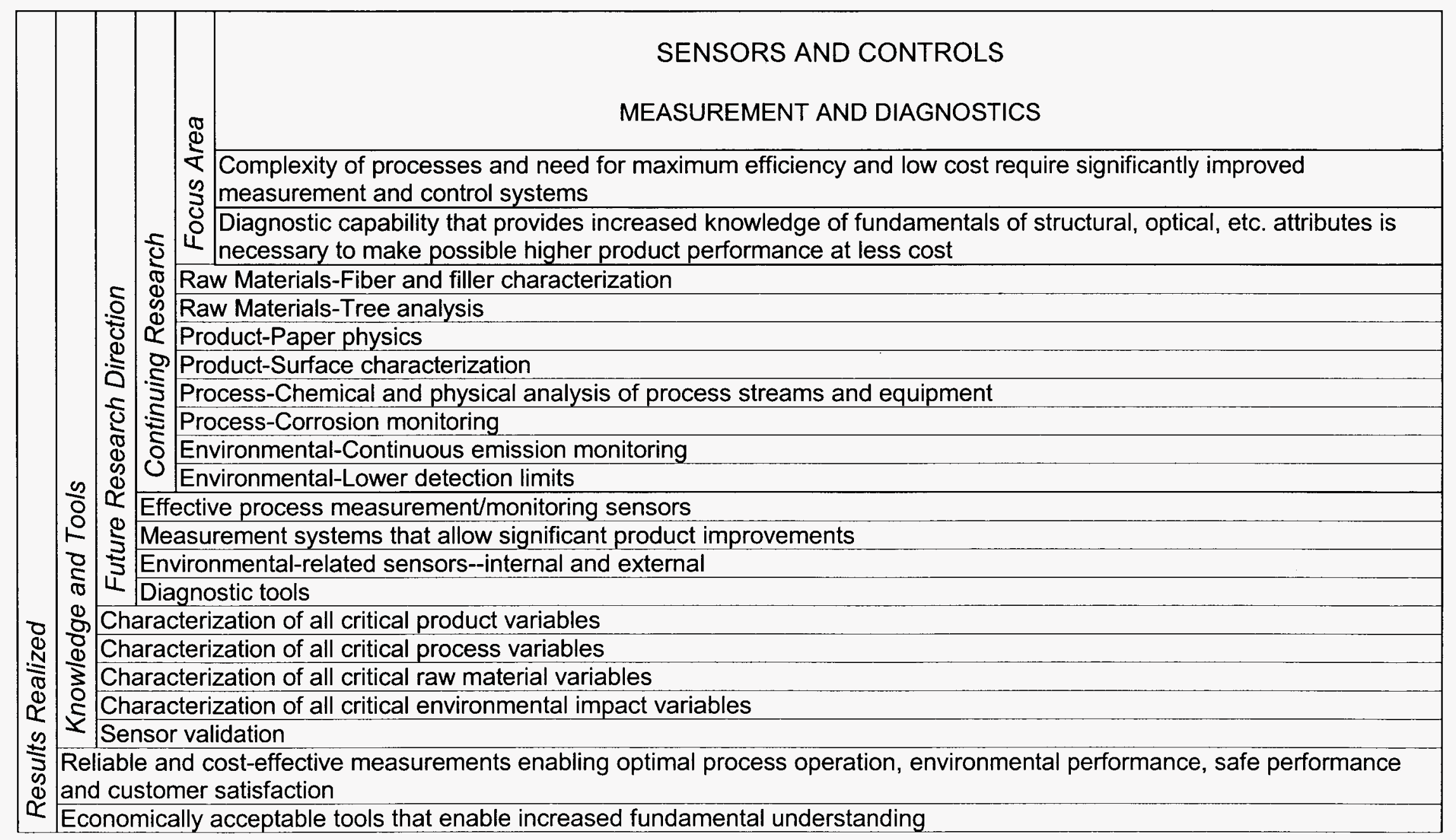


FOREST PRODUCTS INDUSTRY OF THE FUTURE - PORTFOLIO STUDY AND EVALUATION

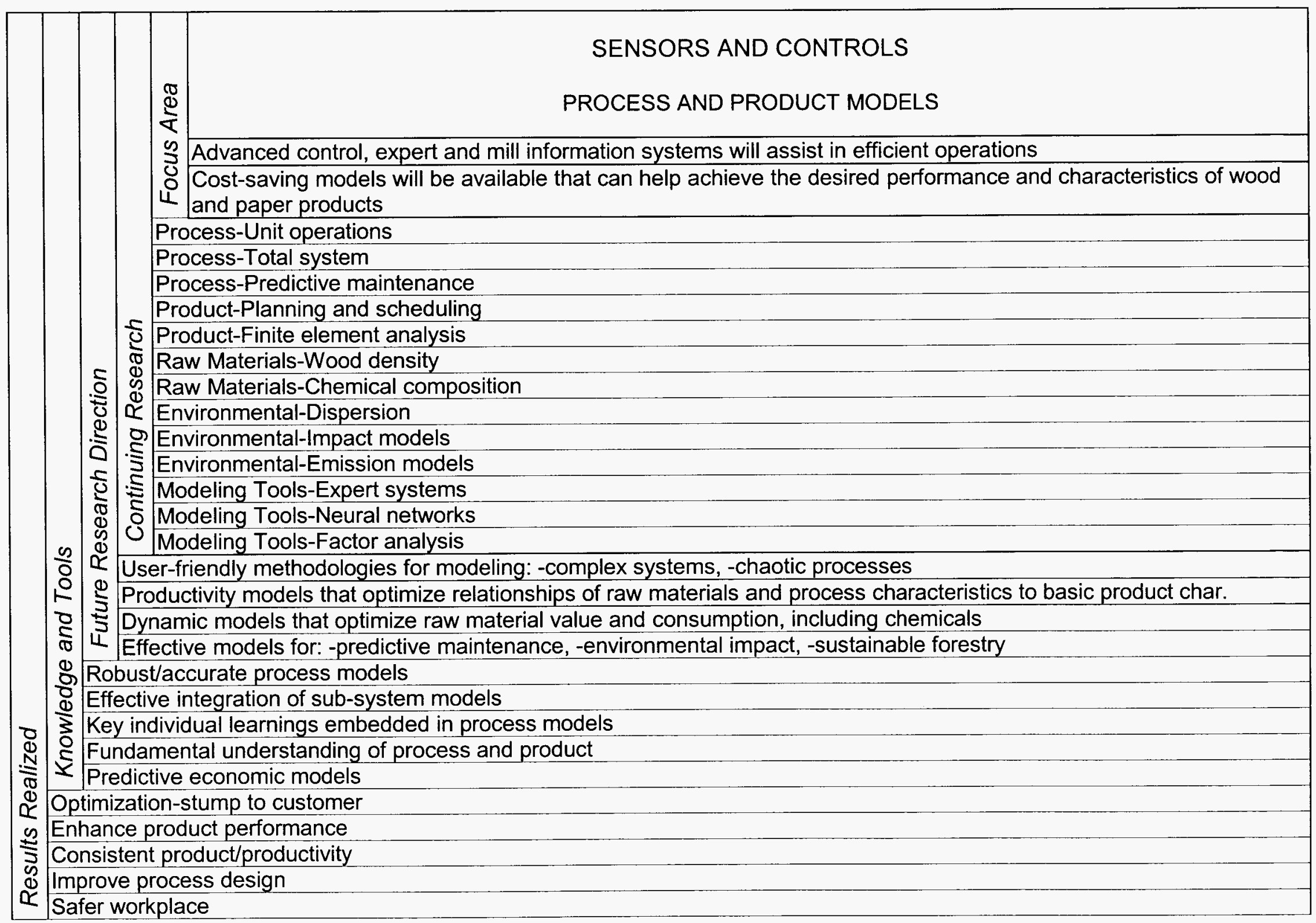




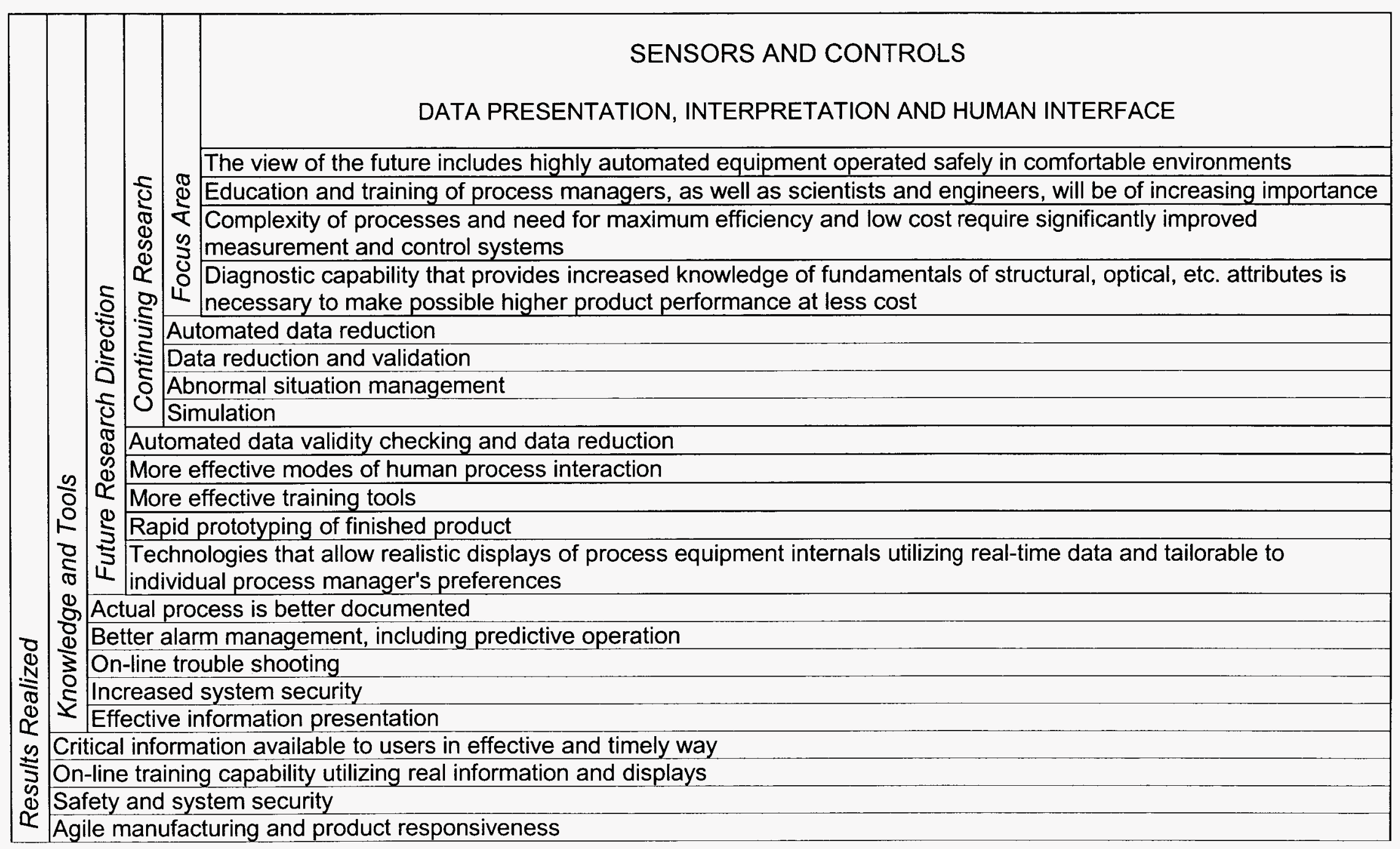


FOREST PRODUCTS INDUSTRY OF THE FUTURE - PORTFOLIO STUDY AND EVALUATION

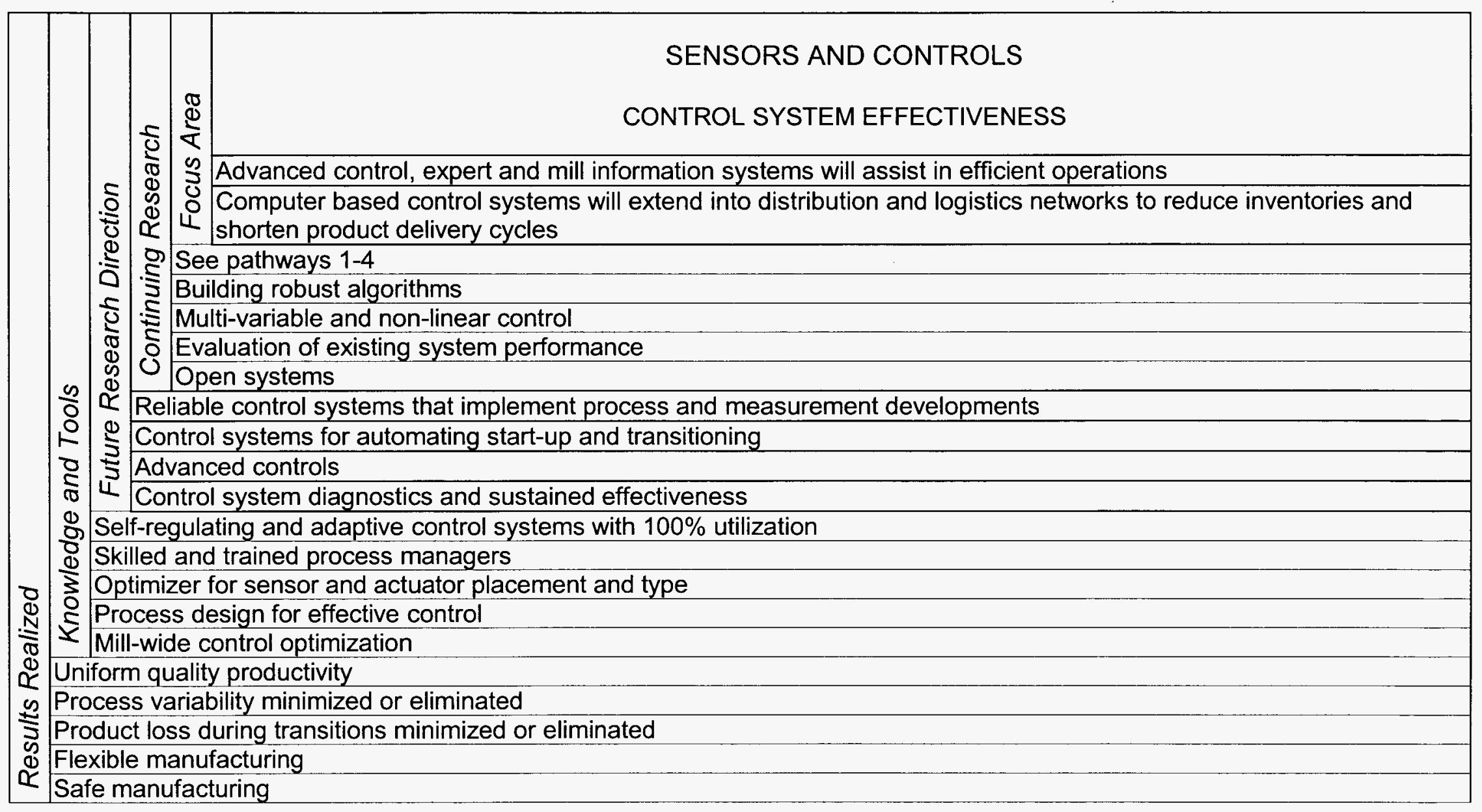




\author{
Appendix G
}

Proposed New Technology Strategy 
FOREST PRODUCTS INDUSTRY OF THE FUTURE - PORTFOLIO STUDY AND EVALUATION

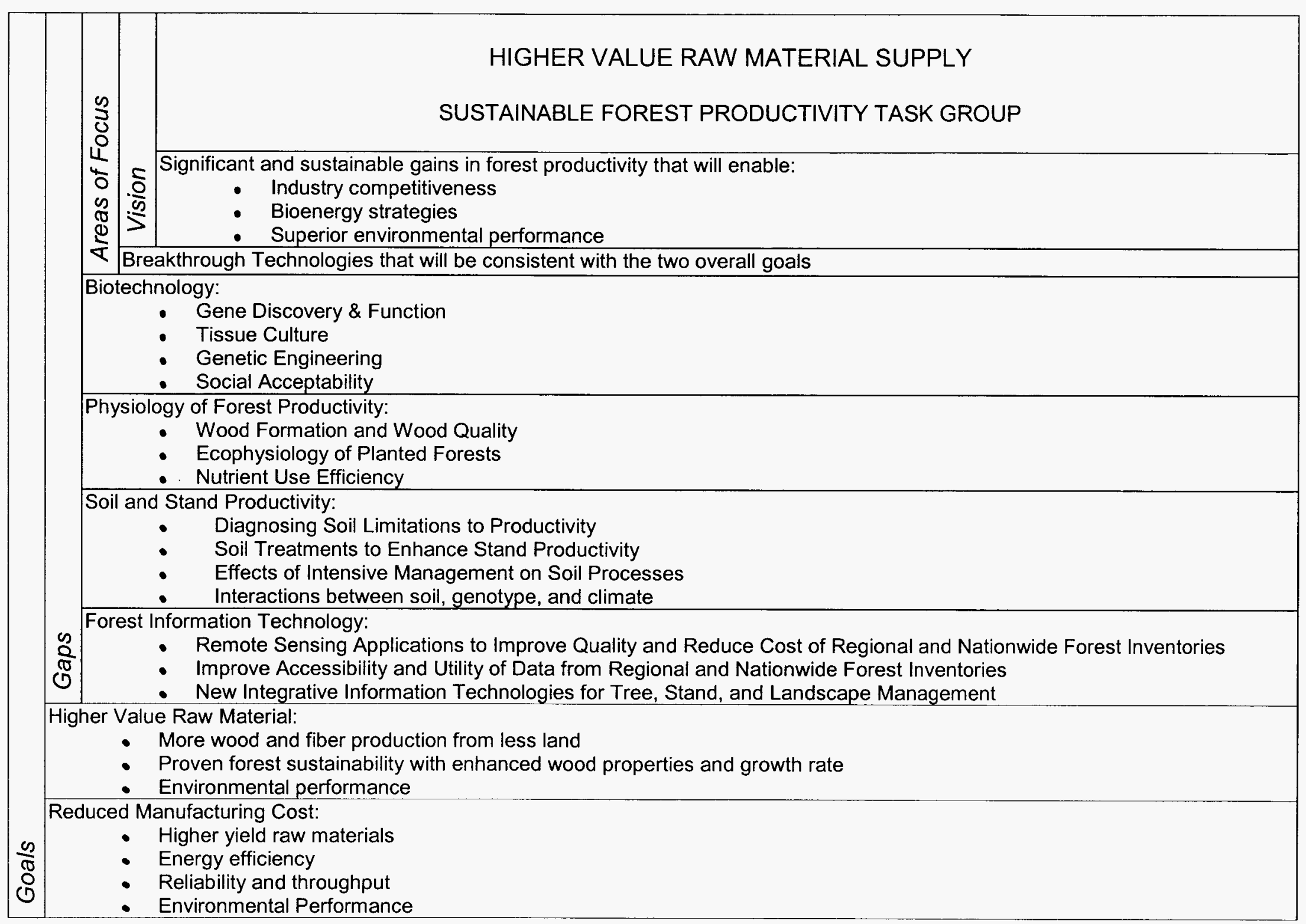


FOREST PRODUCTS INDUSTRY OF THE FUTURE - PORTFOLIO STUDY AND EVALUATION

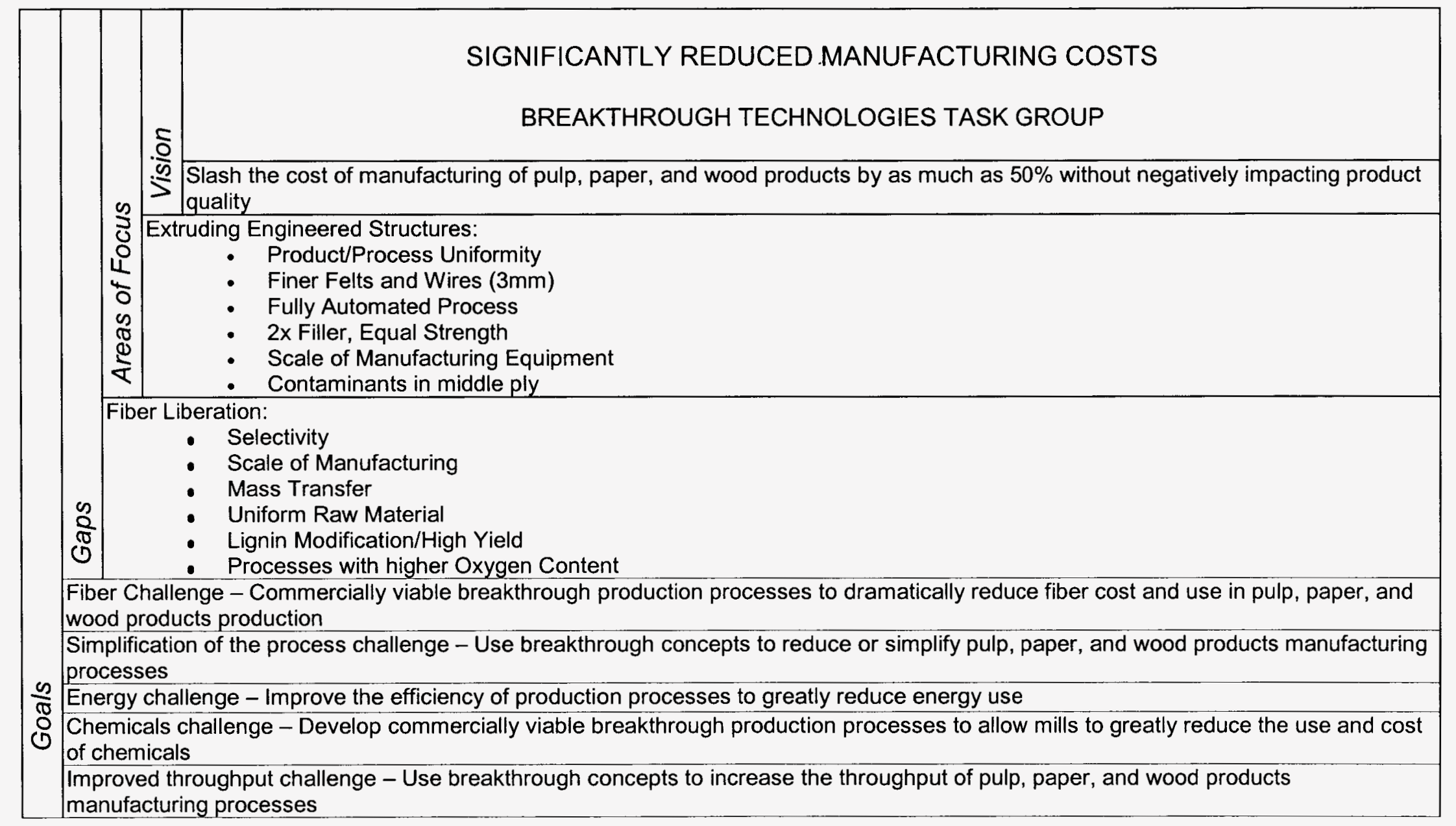


FOREST PRODUCTS INDUSTRY OF THE FUTURE - PORTFOLIO STUDY AND EVALUATION

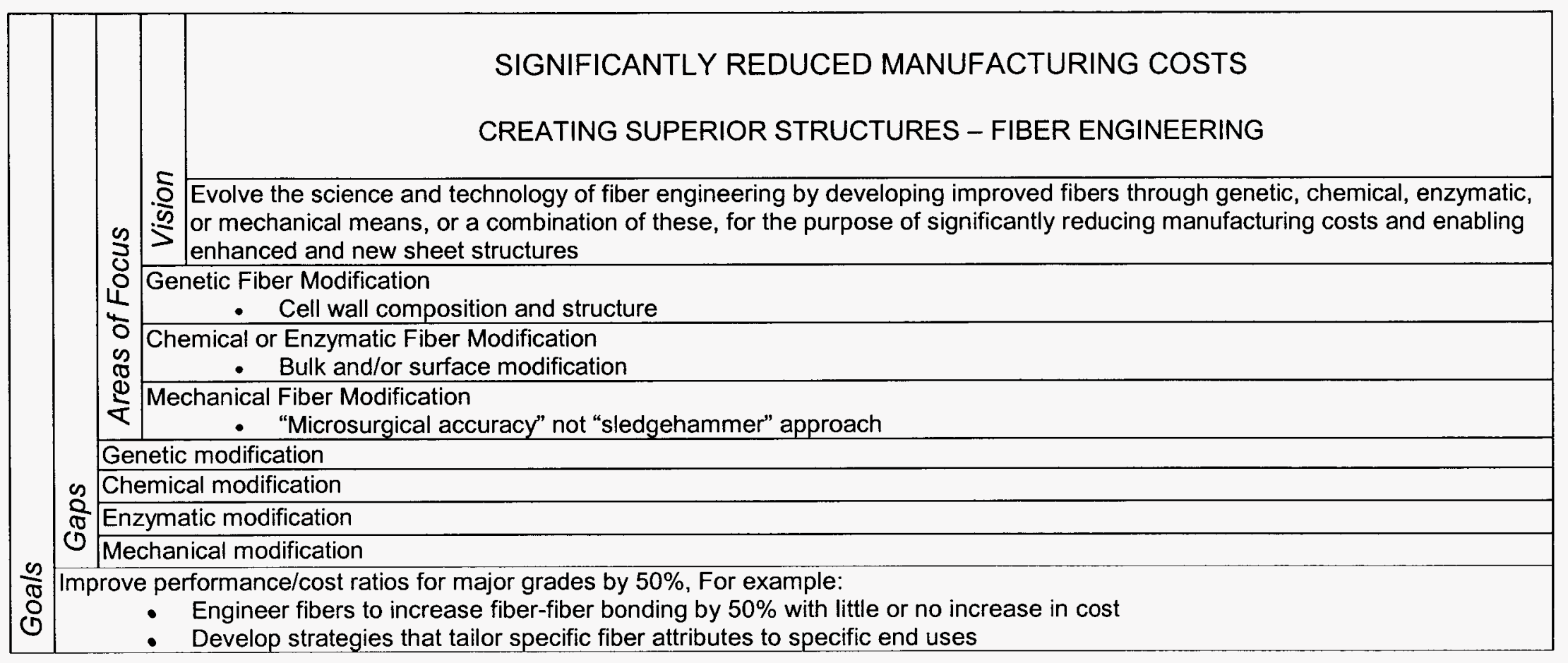


FOREST PRODUCTS INDUSTRY OF THE FUTURE - PORTFOLIO STUDY AND EVALUATION

\begin{tabular}{|l|l|l|l|}
\hline & & & \\
\end{tabular}




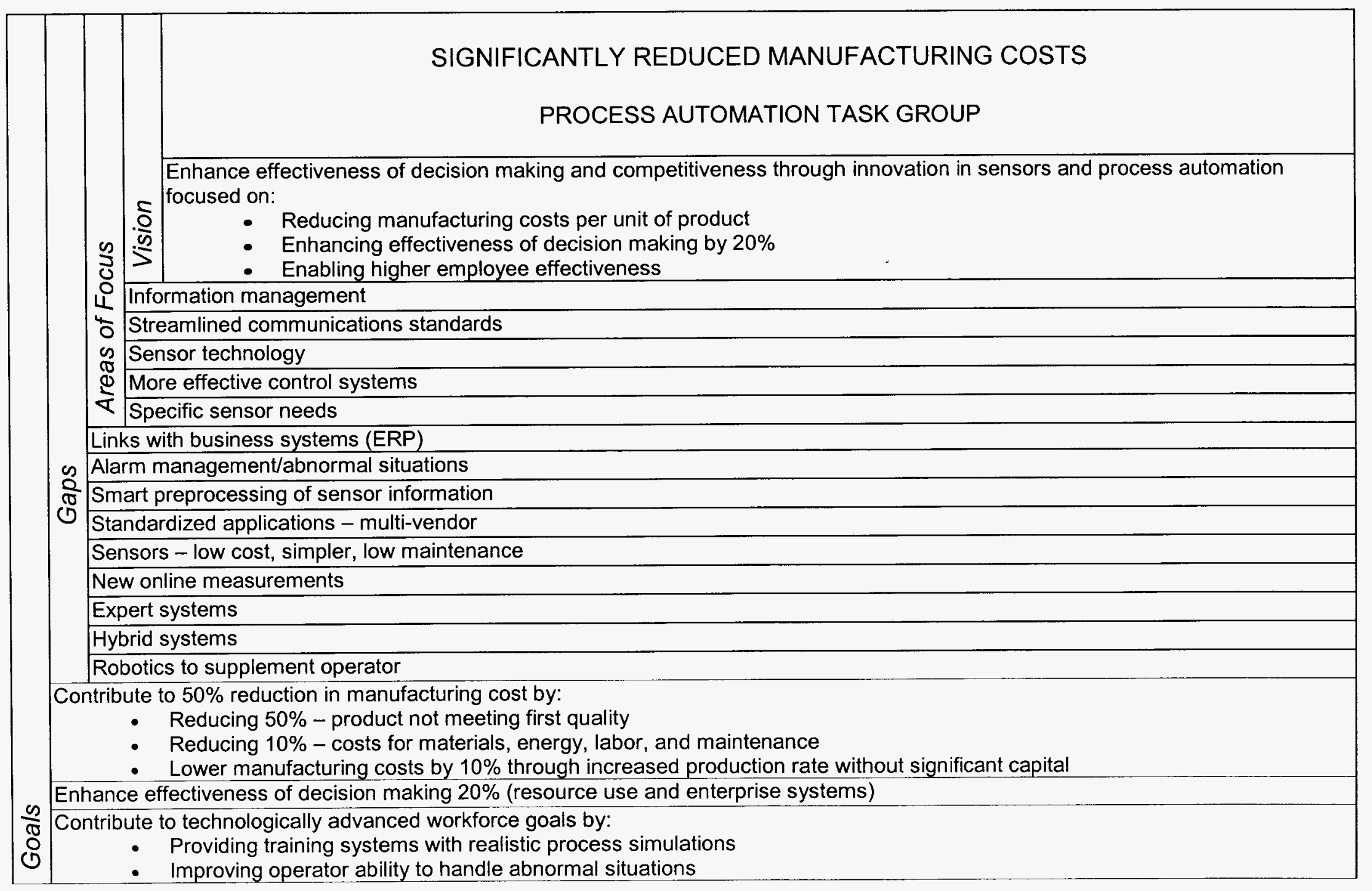


FOREST PRODUCTS INDUSTRY OF THE FUTURE - PORTFOLIO STUDY AND EVALUATION

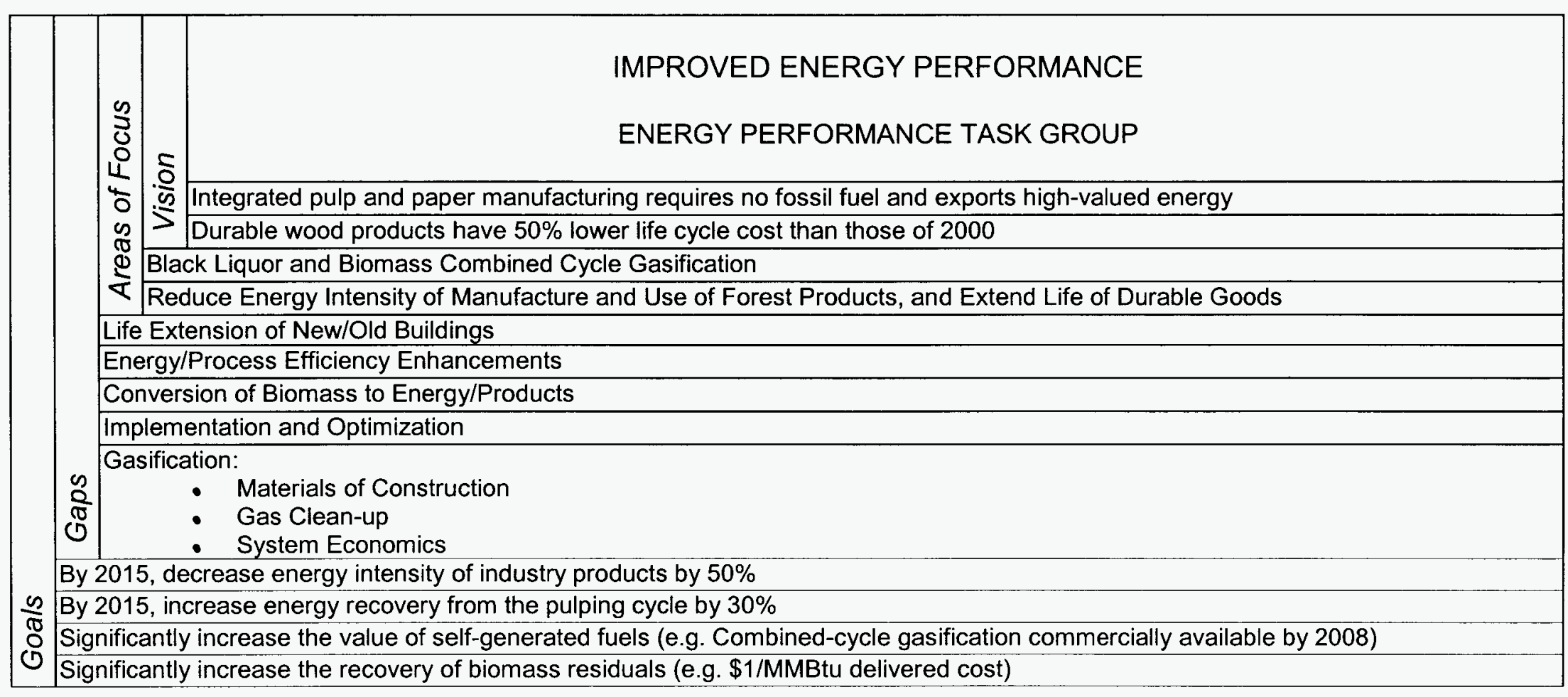




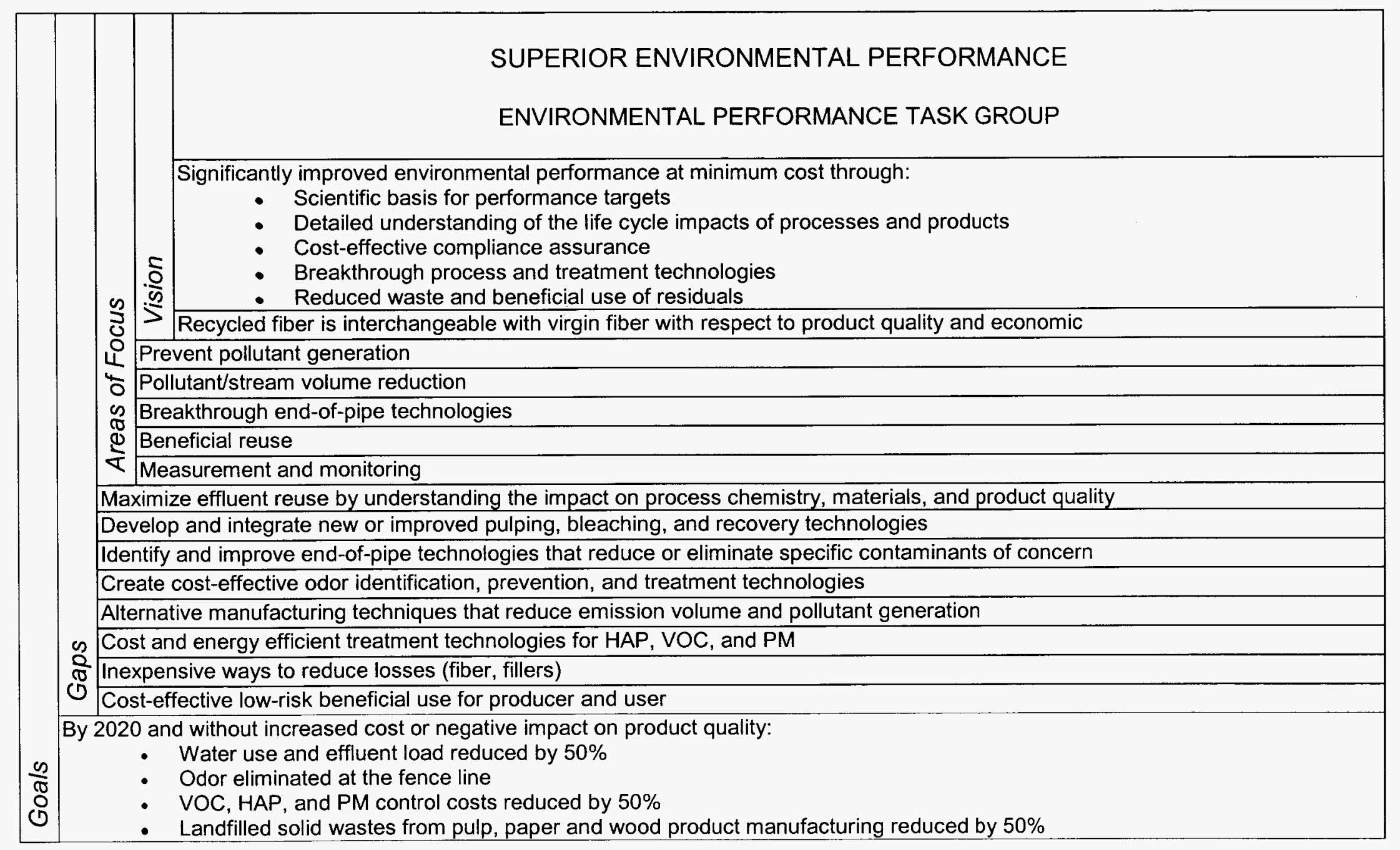


FOREST PRODUCTS INDUSTRY OF THE FUTURE - PORTFOLIO STUDY AND EVALUATION

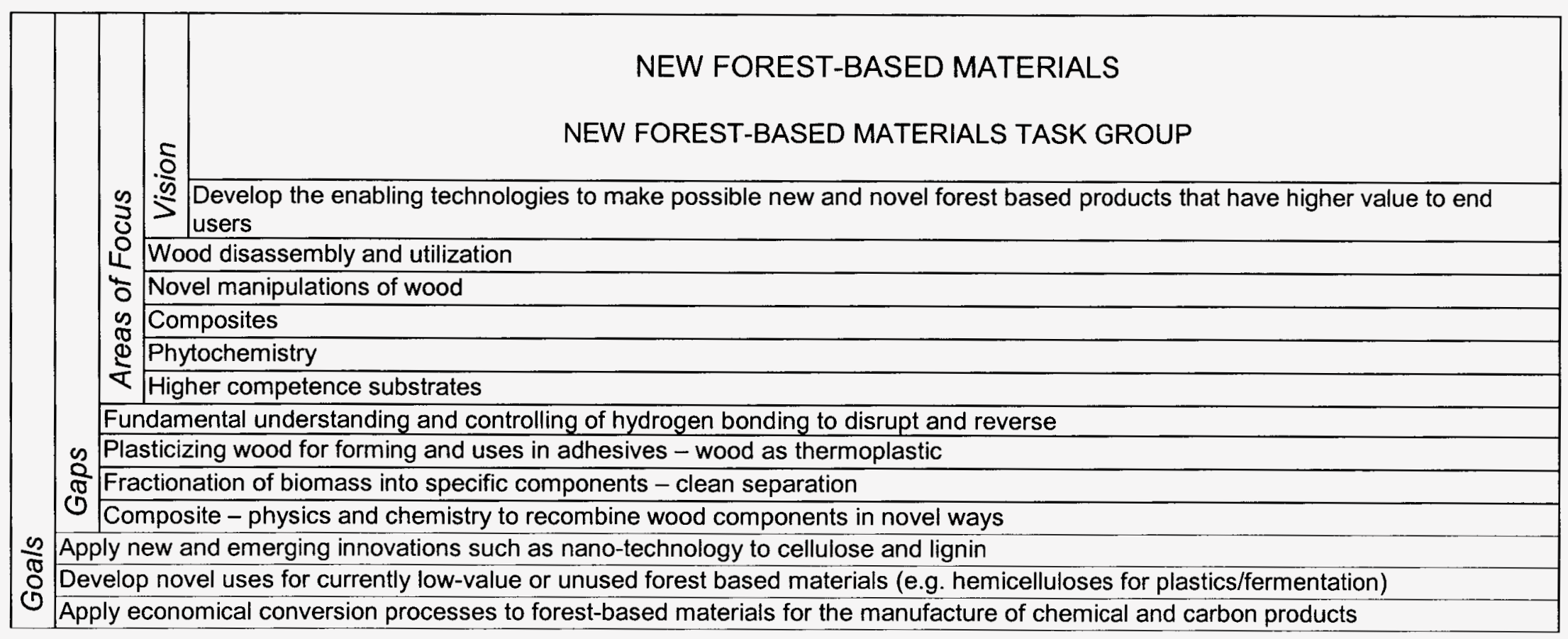


FOREST PRODUCTS INDUSTRY OF THE FUTURE - PORTFOLIO STUDY AND EVALUATION

\begin{tabular}{|l|l|l|l|}
\hline & TECHNOLOGICALLY ADVANCED WORKFORCE \\
\hline
\end{tabular}




\title{
INDUCED POLARIZATION WITH ELECTROMAGNETIC COUPLING: 3D SPECTRAL IMAGING THEORY EMSP PROJECT NO. 73836
}

\section{TOPICAL/ANNUAL PROGRESS REPORT}

for Period September 15, 2001-September 14, 2002

\author{
F. Dale Morgan, Principal Investigator \\ Earth Resources Laboratory \\ Department of Earth, Atmospheric, and Planetary Sciences \\ Massachusetts Institute of Technology \\ Cambridge, Massachusetts 02139 \\ Tel. 617/253-7857 \\ morgan@erl.mit.edu \\ Graduate Students: \\ Current: Darrell Coles (June 2003) \\ Past: Michael Lambert (2002-2003) \\ Lisa Lassner (2001-2002) \\ Weiqun Shi (1996-1998) \\ Amy Vandiver (1997-1999)
}

May 1, 2003

Prepared for

THE U.S. DEPARTMENT OF ENERGY

AGREEMENT NO. DE-FG07-96ER14714 


\section{RESEARCH PROGRESS AND IMPLICATIONS:}

This report summarizes the research work completed on the project between December 2001 and September 2002.

1. A model of all Spectral IP capacitive couplings revealed that potential bearing electrodes should be carefully chosen to obviate some of the capacitive coupling problems. This need becomes more important for borehole sampling. Thus, work had been done to design a porous pot electrode that has all the desired characteristics (low input impedance $\leq 100 \Omega$, low noise $\leq 1 \mu \mathrm{V} / \sqrt{\mathrm{Hz}}$, low temperature sensitivity $\leq 10 \mu \mathrm{V} /{ }^{\circ} \mathrm{C}$ ) and that can be implanted in a borehole for up to two years. Further constructional/fabrication details will be given in the final report. The attached pictures are from a sample of the prototype electrode. Four strings, each consisting of 14 electrodes ( 7 potential electrodes alternated with 7 metallic-copper current electrodes, each electrode $6 \mathrm{ft}$ apart), were constructed and are to be deployed into the four boreholes. (They were eventually deployed in Dec. 2002 and measurements acquired in March 2003).

2. The MIT's Earth Resources Laboratory (ERL) performed Spectral Induced Polarization (SIP) and Time Domain Induced Polarization (TDIP) measurements at the A-14 Outfall during the summer of FY01 as a participant in a DOE-sponsored exercise to assess the state-of-the-art in cross-borehole IP technology for delineating subsurface contaminants. To demonstrate the utility of SIP to map DNAPL contaminants, we inverted cross-borehole SIP data, taken within a very narrow frequency bandwidth of $1 / 32$ to $9 / 32 \mathrm{~Hz}$. The narrow bandwidth was selected after carefully studying when effects of emc, electrode polarization, etc. begin to set in. The upper frequency is limited by electromagnetic couplings (emc) and strong capacitive behavior observed for the electrodes and the lowfrequency limit is set by the time to take measurements. Because below $9 / 32 \mathrm{~Hz}$, the IP response seems to be greater than emc in all our measurements, the data was considered invertible by our existing $2 \mathrm{D} / 3 \mathrm{D}$ complex resistivity codes. The results of this exercise were inconclusive because the ground-truthing phase of the operation failed to detect any concentration of NAPL above a requisite threshold of $40-50 \mu \mathrm{g} / \mathrm{g}$. It is our understanding that this threshold level is based upon analytic chemical partition analysis, which is dependent upon the physicochemical properties of the soil, its pore-fluid, and organic constituents [Cohen and Mercer, 1993], and thus represents a necessary and sufficient condition to confirm the presence of NAPL. Therefore, since the ground-truthing phase never found PCE concentrations in excess of $\sim 3 \mu \mathrm{g} / \mathrm{g}$, there is no irrefutable evidence of NAPL; hence, the objective of the FY01 exercise 
could not be completed. Nonetheless, ERL's inversion results (an example is shown in Figure 1) agree well with the ground truth considering the sparseness of the CRS boreholes, low concentrations of 'PCE' $(<3 \mu \mathrm{g} / \mathrm{g})$, and despite poor electrodes. Note that the displacement of the center of the SIP phase anomaly from that of the ground truth data might be due to inaccuracies in the SIP inversion (which we are still working on improving) or sampling depth errors during the ground-truthing phase which could cumulatively amount to a meter or more.

3. As a continuation of the FY01 efforts, another set of surface and borehole SIP measurements were planned at another SRS site during FY02, which unlike the FY01 site, had been verified to have substantial DNAPL presence by SRS engineers. The plan to use Phoenix Geophysics SIP equipment could not materialize because Phoenix discontinued its SIP line and planned to introduce a new line in the Spring/Summer of 2003, which will be too late for us. So our planned second fieldwork of FY02 defaults again to Zonge Engineering and Research Organization equipment.

4. Developments on the modeling and inversion of the new complex resistivity code, that will incorporate inductive coupling, stalled to give way to the electrode design, fabrication and testing(s), which were not anticipated earlier.

\section{Reference}

Cohen, R., Mercer, J., Mathews, J. (EPA Project Officer), DNAPL Site Evaluation, C.K. Smoley, 1993

\section{PLANNED ACTIVITIES}

The following shows a timetable of activities planned for the remaining time of the project:

October 2002 to March 2003: Completion of the formulation of the forward and inverse algorithms.

October 2002 to March 200: More field work using Zonge Engineering and Research Organization SIP equipment.

March 2003 to May 2003: Testing of the inverse algorithms using both synthetic and field data.

June 2003 to July 2003: More demonstration field work possibly at Savannah River Site A14 outfall.

July 2003 to September 2003: Interpretation of field results and writing of reports. 


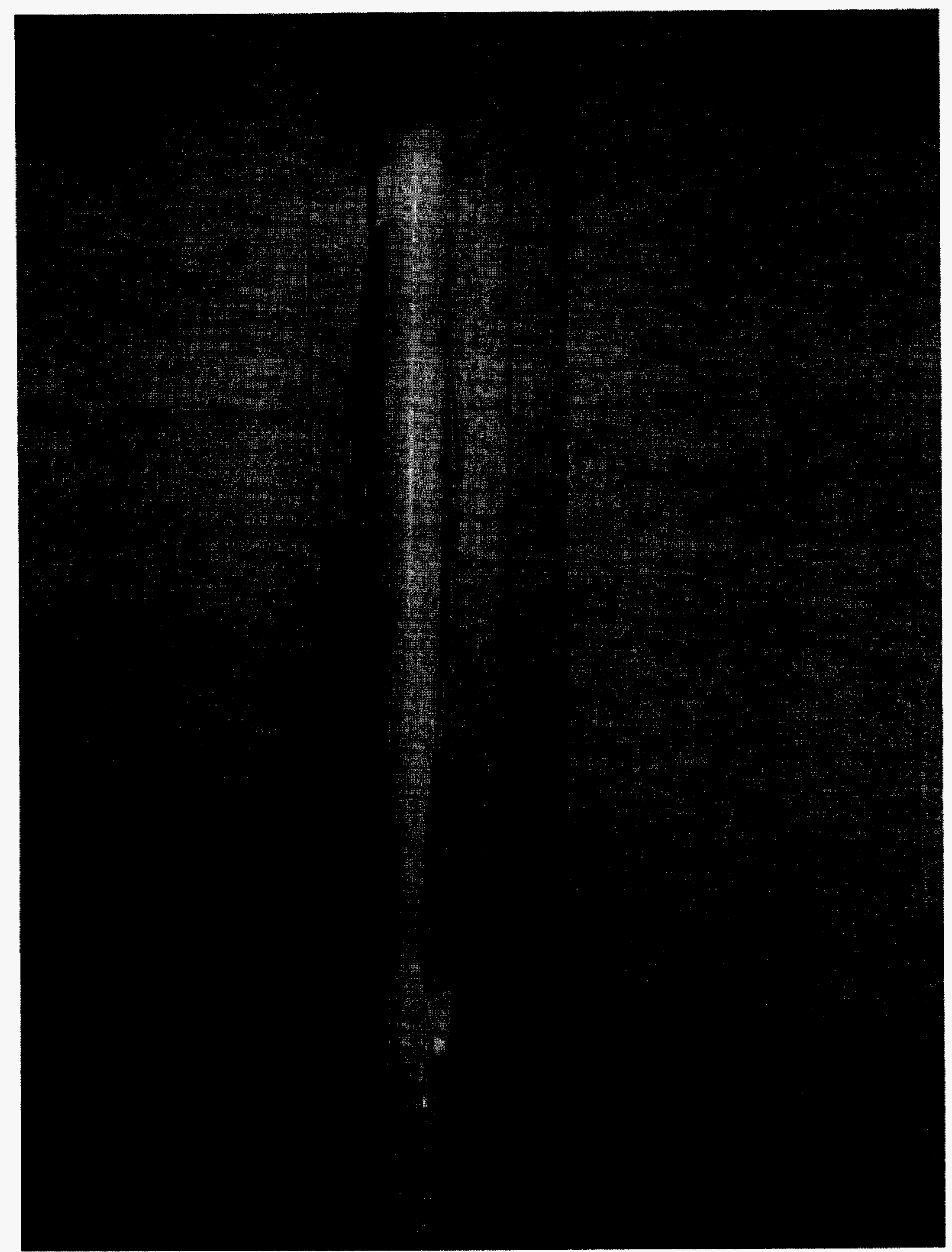

Figure 1 a: Porous pot electrode Potential- shown with protective (red) cover. 


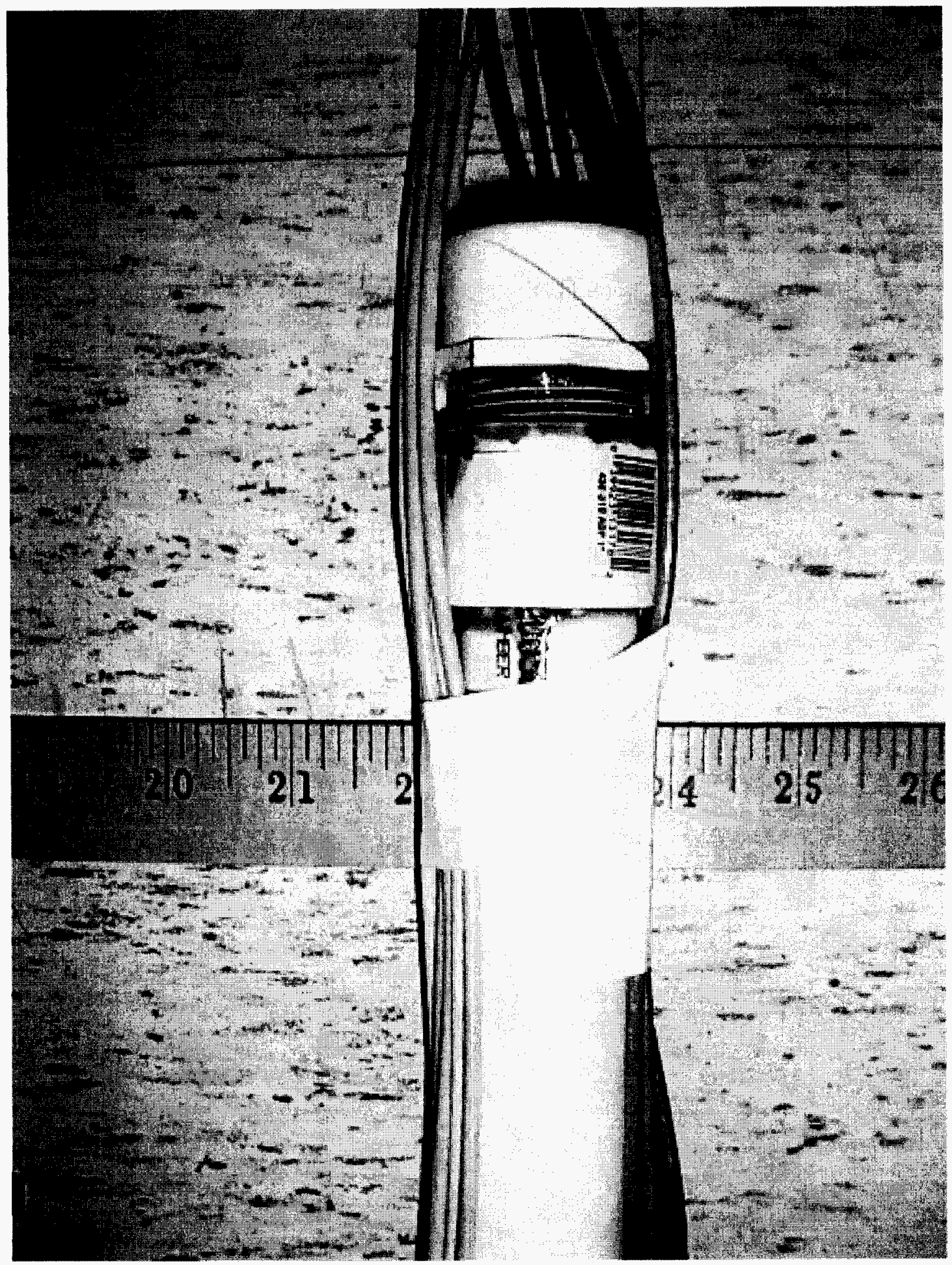

Figure 1 b: Porous pot electrode Potential- width. 


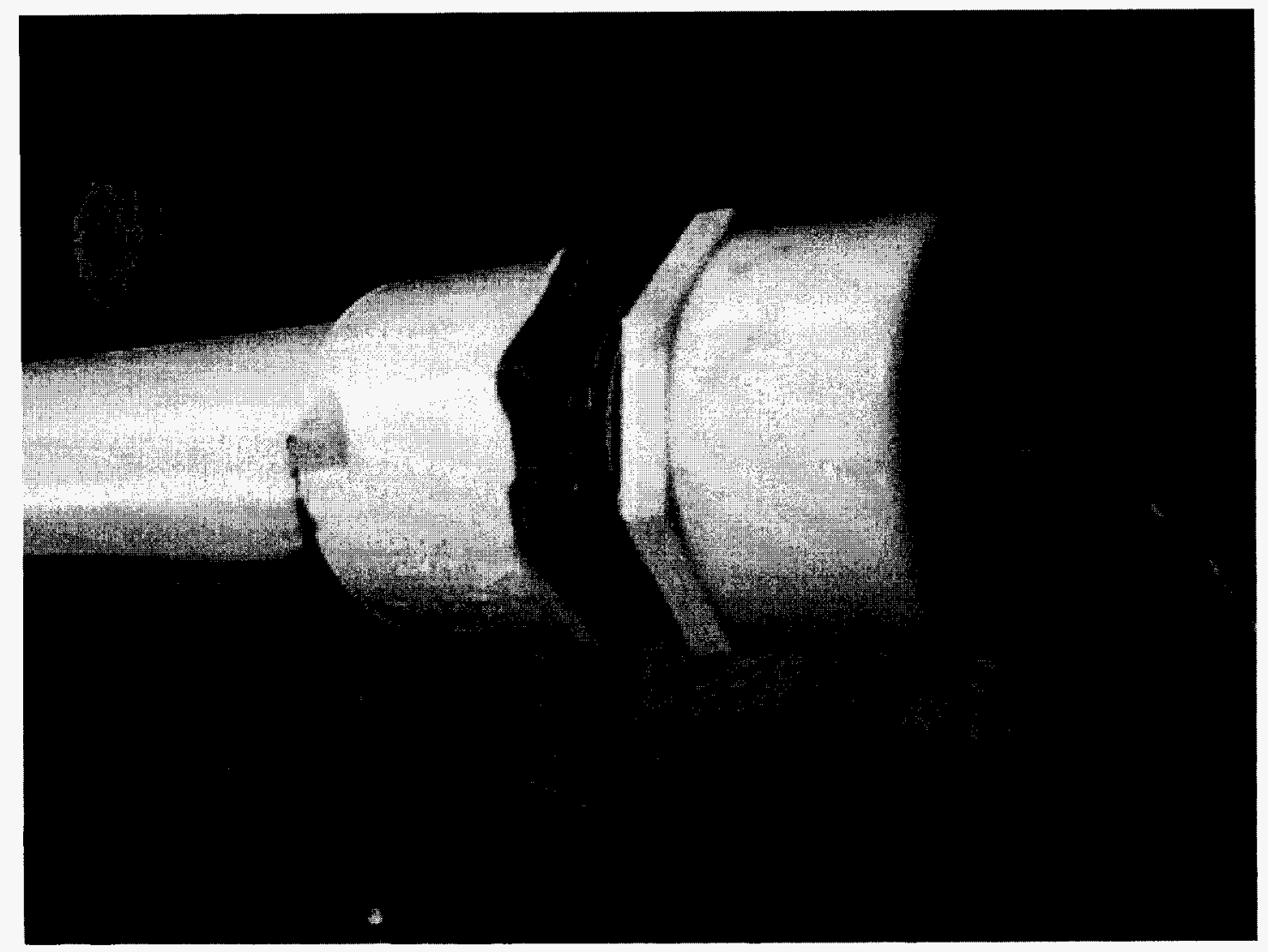

Figure 1 c: Porous pot electrode Potential- showing the cap. 
Below is an image that shows the interpolated ground truth concentration of an "unidentified" substance but labeled PCE by SRS ground-truthing team.

PCE-IP ground truth comparison at the A-14 Outfall
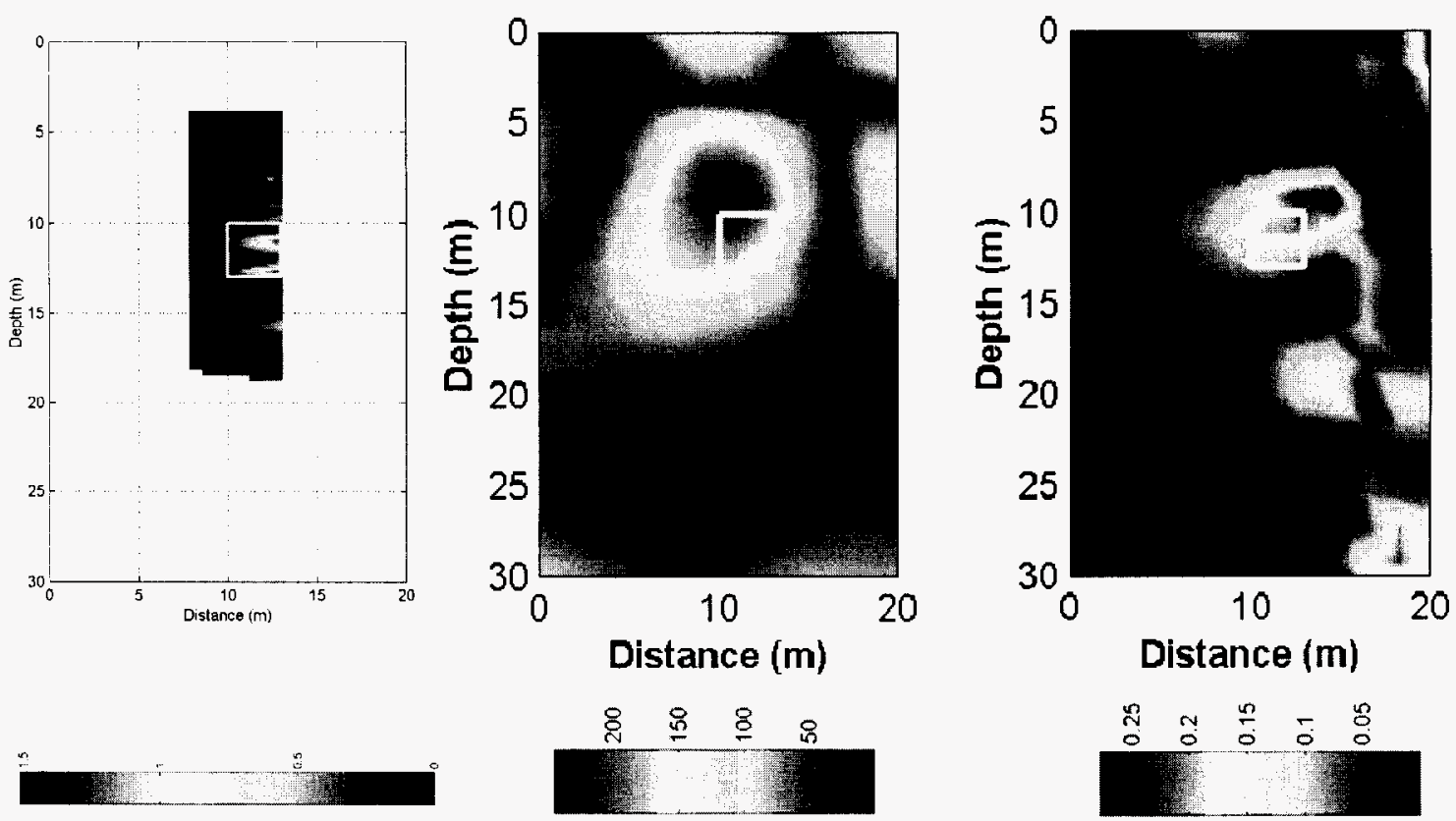

Figure 2 Comparison of the ground-truth PCE anomaly (a), the ERL's SIP anomaly (b), and the ERL's TDIP anomaly (c). Panel a has been generated by taking a slice along the MES-2/MES-4 panel from the volumetric PCE concentration (interpolated from the CRS series of boreholes, taken during the FY01 ground-truth exercise). Panels $\mathbf{b}$ and $\mathbf{c}$ are the ERL's inversion results along the MES-2/MES-4 panel. MES4 is located on the right-hand side of all three panels. 